\title{
EFFECTS OF ABSORPTION ENHANCER SURFACTANTS ON CULTURE MODELS OF INTESTINAL AND VASCULAR BARRIERS
}

\author{
Ph.D. thesis
}

\section{Lóránd Kiss}

Supervisors:

Dr. Mária Deli, M.D., Ph.D., D.Sc.

Prof. Piroska Szabó-Révész, M.Pharm., Ph.D., D.Sc.

SZEGED

2014 


\section{CONTENTS}

Publications related to the subject of the thesis

Other publications

Abbreviations

1. Introduction

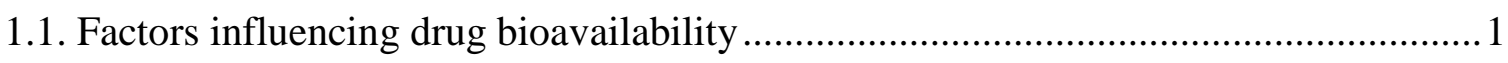

Transport pathways across biological barriers ................................................... 2

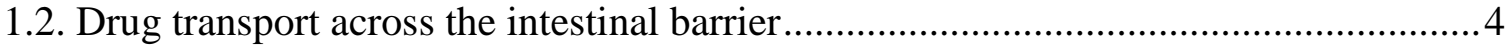

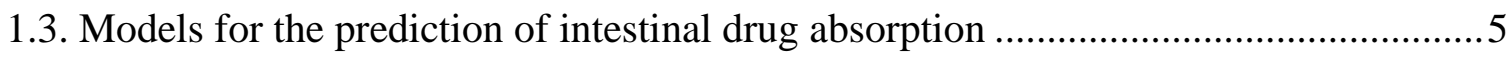

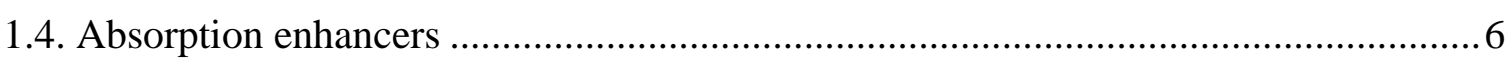

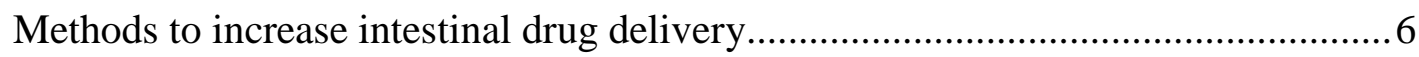

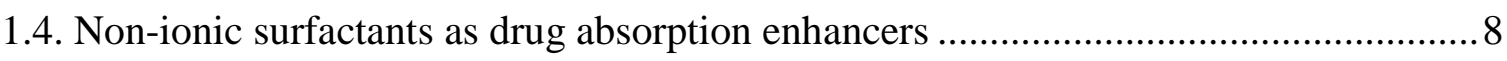

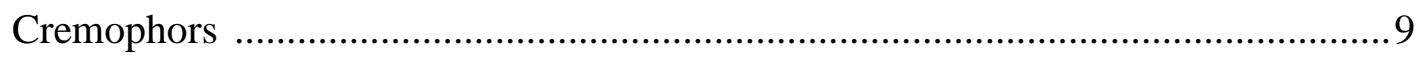

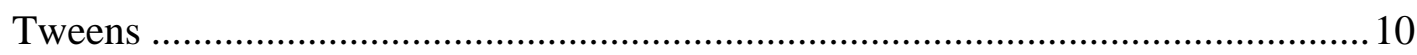

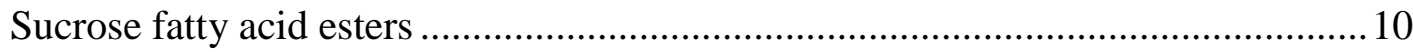

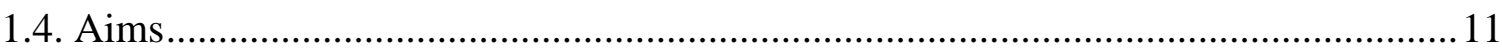

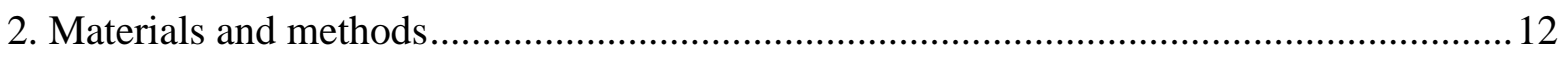

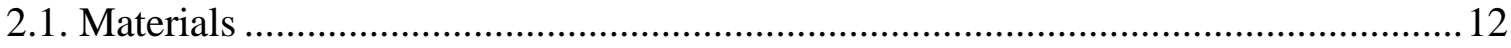

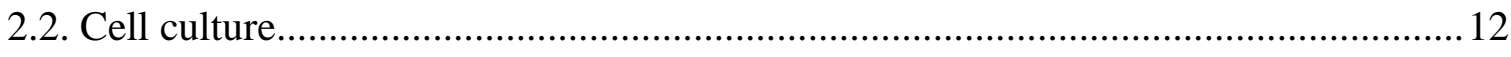

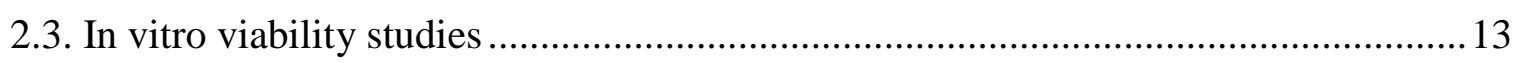

2.3.1. Treatment concentrations and intervals......................................................... 13

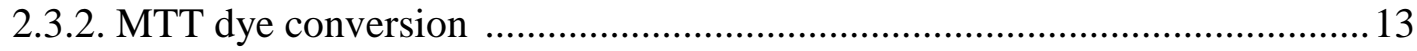

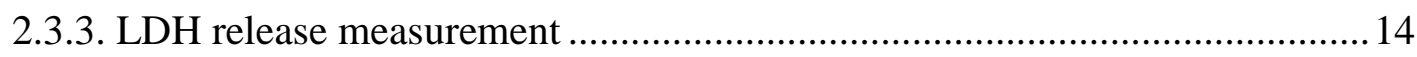

2.3.4. Double fluorescent staining of cell nuclei................................................. 14

2.4. Fluorescent actin-labeling and immunostainings for junctional proteins ....................15

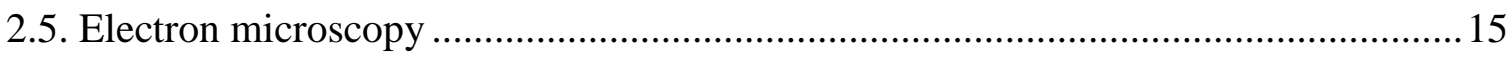

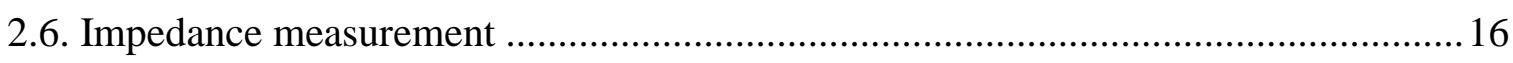

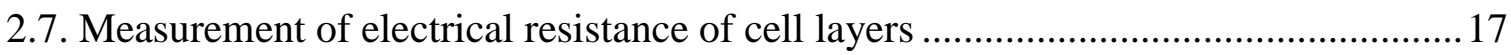

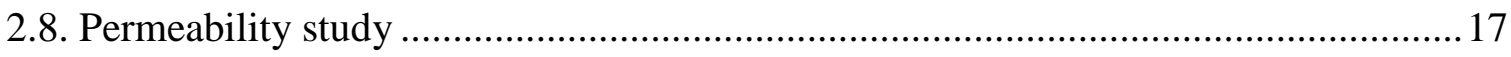

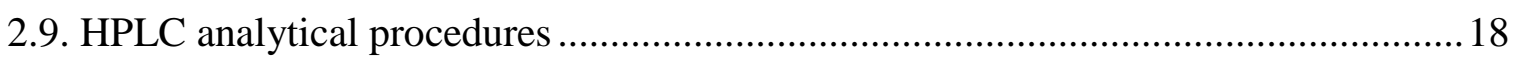

2.10. Measurement of plasma membrane fluidity in Caco-2 cells ..................................19

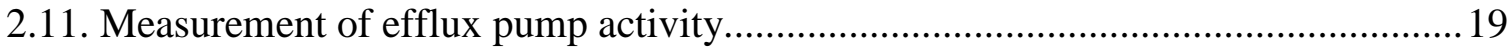

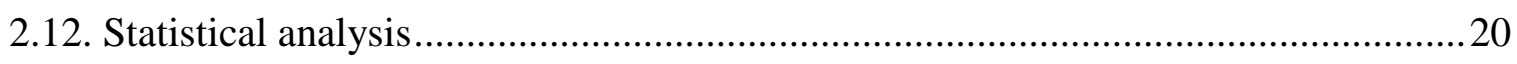

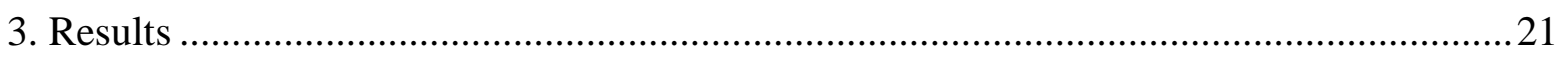

3.1. Effects of non-ionic surfactants on viability of intestinal and vascular

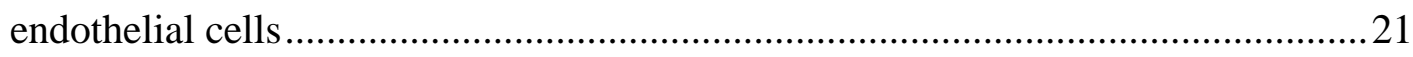

3.2. Effects of sucrose esters and reference surfactants on the electrical resistance and impedance of epithelial cell layers 
3.3. Effects of surfactants on epithelial cell layer permeability for drugs and fluorescein

3.4. Effects of sucrose esters and reference surfactants on the epithelial intercellular junctions.

3.5. Effects of sucrose esters and reference surfactants on epithelial cell membranes .32

3.5. Effects of sucrose esters and reference surfactants on efflux pump activity. .33

4. Discussion .35

4.1. Surfactants and cellular toxicity .35

4.1.1. Comparison of the effects of Cremophor RH40 and EL on viability of intestinal epithelial and vascular endothelial cells

4.1.2. Effects of sucrose esters and reference surfactants on epithelial cellular viability .37

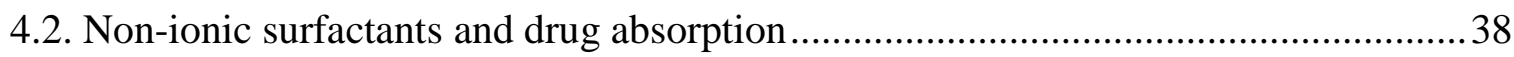

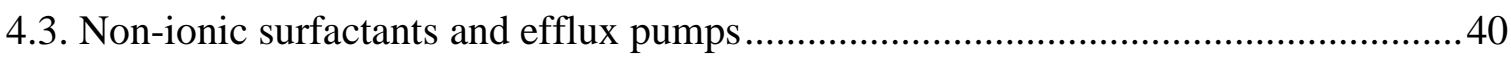

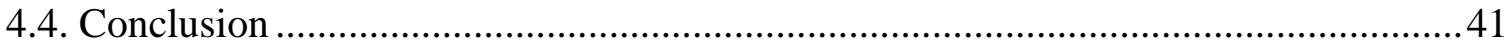

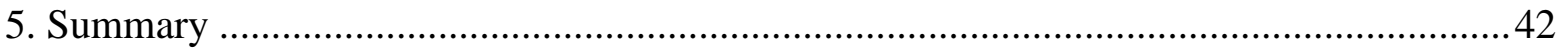

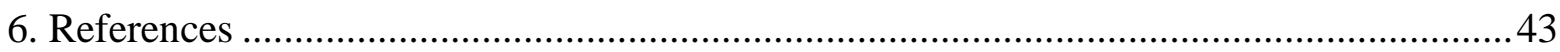

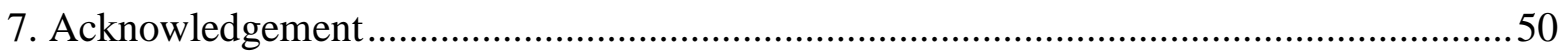

Appendix 


\section{PUBLICATIONS RELATED TO THE SUBJECT OF THE THESIS}

I. Szüts A, Láng P, Ambrus R, Kiss L, Deli MA, Szabó-Révész P.

Applicability of sucrose laurate as surfactant in solid dispersions prepared by melt technology

International Journal of Pharmaceutics 410: 107-110 (2011)

IF: 3.350

II. Kiss L, Walter FR, Bocsik A, Veszelka S, Ozsvári B, Puskás LG, Szabó-Révész P, Deli MA.

Kinetic analysis of the toxicity of pharmaceutical excipients Cremophor EL and RH40 on endothelial and epithelial cells

Journal of Pharmaceutical Sciences, 102:1173-81 (2013)

IF: $3.130(2012)$

III. Kiss L, Hellinger E, Pilbat AM, Kittel A, Török Z, András Füredi, Gergely Szakács, Veszelka S, Sipos P, Ózsvári B, Puskás LG, Vastag M, Szabó-Révész P, Deli MA.

Sucrose esters increase drug penetration, but do not inhibit P-glycoprotein in Caco-2 intestinal epithelial cells.

Journal of Pharmaceutical Sciences (Accepted for publication on June 14, 2014, manuscript number: 14-194)

IF: $3.130(2012)$

\section{OTHER PUBLICATIONS}

I. Horvát S, Fehér A, Wolburg H, Sipos P, Veszelka S, Tóth A, Kis L, Kurunczi A, Balogh G, Kürti L, Erős I, Szabó-Révész P, Deli MA.

Sodium hyaluronate as a mucoadhesive component in nasal formulation enhances delivery of molecules to brain tissue

European Journal of Pharmaceutics and Biopharmaceutics 72: 252-259 (2009)

IF: 4.304

II. Horvát S, Kis L, Szabó-Révész P, Erős I, Deli MA.

Targeting pharmacons to the brain via the nasal pathway

Gyógyszerészet 53: 259-266 (2009)

IF: -

III. Jańczewski D, Song J, Csányi E, Kiss L, Blazsó P, Katona RL, Deli MA, Gros G, Xu J and Vancso JG.

Organometallic polymeric carriers for redox triggered release of molecular payloads

Journal of Mataterials Chemistry 22: 6429-6435 (2012)

IF: 6.101

IV. Némethy Á, Solti K, Kiss L, Gyarmati B, Deli MA, Csányi E, Szilágyi A.

$\mathrm{pH}$ and temperature responsive poly(aspartic acid)-1-poly( $N$-isopropylacrylamide) conetwork hydrogel

European Polymer Journal 49: 2392-2403 (2013)

IF: 2.562 (2012) 


\section{ABBREVIATIONS}

$\mathrm{AB}$

$\mathrm{ABC}$

BA

CE

CI

CMC

CR

CycA

D

D-1216

DMEM

DMSO

Eq.

EthD-1

F-actin

Fig.

GI

H33342

HIV

HLB

LDH

$\mathrm{M}$

M-1695

MTT

NSAID

$\mathrm{P}$

P-1695

PAMPA

$\mathrm{P}_{\text {app }}$

PBS

Pub.

SLC

TEER

$\mathrm{TJ}$

TMA-DPH

Tw

U

Ver

ZO-1

$\mathrm{ZO}-2$
Apical to basal direction

ATP-binding cassette transporters

Basal to apical direction

Cremophor EL

Cell index

Critical micelle concentration

Cremophor RH40

Cyclosporin A

Laurate sucrose fatty acid ester, D-1216

Laurate sucrose fatty acid ester

Dulbecco's Modified Eagle Medium

Dimethyl-sulfoxide

Equation

Ethidium homodimer-1

Filamentous actin

Figure

Gastrointestinal

Hoechst 33342 or bis-benzimide

Human Immunodeficiency Virus

Hydrophilic-lipophilic balance

Lactate dehydrogenase

Myristate sucrose fatty acid ester, M-1695

Myristate sucrose fatty acid ester

3-(4,5-dimethyltiazol-2-yl)-2,5-diphenyltetrazolium bromide

Non-Steroidal Anti-Inflammatory Drug

Palmitate sucrose fatty acid ester, P-1695

Palmitate sucrose fatty acid ester

Parallel artificial membrane penetration assay

Apparent permeability coefficient

Phosphate buffered saline

Publication

Solute carrier transporters

Transepithelial electrical resistance

Tight junction

1-(4-trimethylammoniumphenyl)-6-phenyl-1,3,5-hexatriene

Tween 80

Unit

Verapamil

Zonula occludens-1

Zonula occludens-2 


\section{INTRODUCTION}

Improving drug absorption is one of the main goals of pharmaceutical research. The pharmacokinetics and barrier penetration of a large number of active molecules are not satisfactory. To increase drug bioavailability pharmaceutical excipients, like absorption enhancers are often used. They improve drug solubility and absorption, protect active ingredients and delay drug release. In addition excipients can reduce the amounts of applied active agents, and by lowering inter-individual variability in systemic exposure increase the prediction of pharmacological effects. There is a need for new, innovative absorption enhancers with more favorable properties and better pharmaceutical profile. Our research and my Ph.D. thesis focus on investigation and comparison of clinically applied and novel pharmaceutical excipients using in vitro culture models of the intestinal and vascular barriers.

\subsection{Factors influencing drug bioavailability}

Several factors influence the bioavailability of drugs, such as physicochemical properties, mainly the low solubility and high molecular size, poor permeability through biological barriers, the application sites, binding to plasma proteins, degradation by enzymes, or the excretion by renal or other organ activity (Fig. 1) (Aungst, 2012).

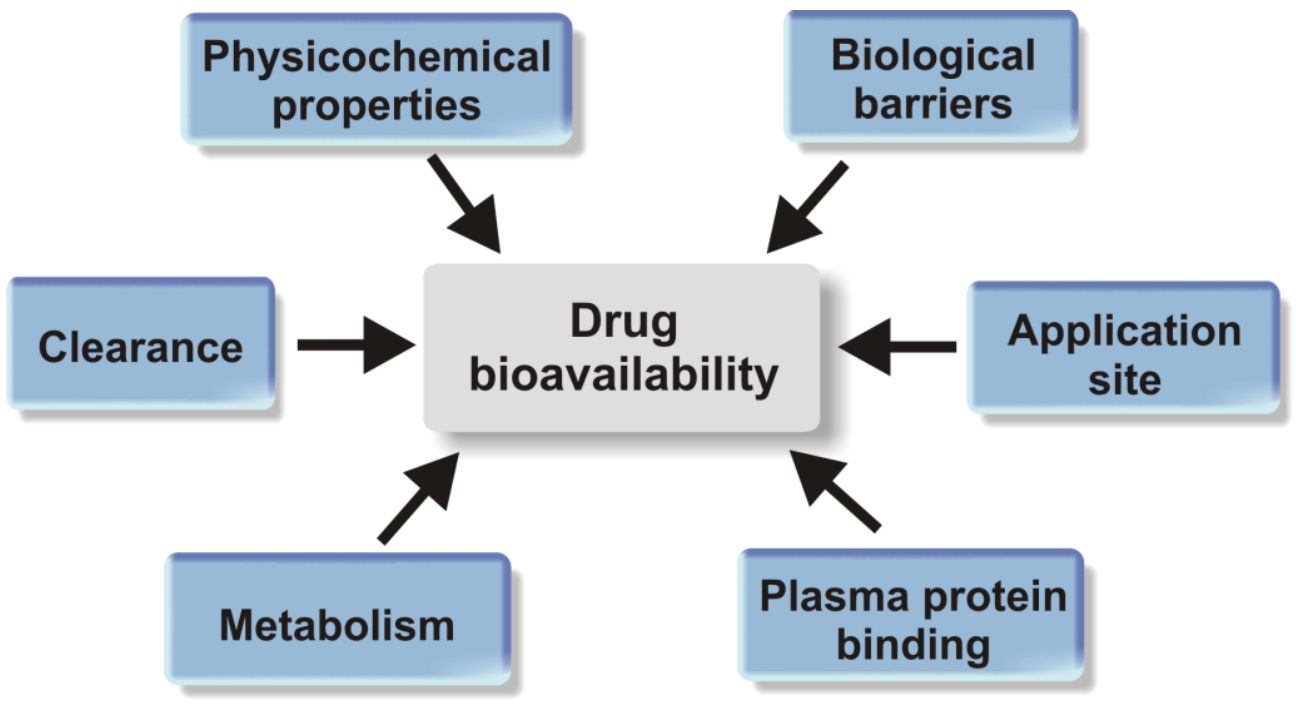

Figure 1. Determining factors of drug bioavailability.

Generally, large molecules, like peptides and protein drugs, have low bioavailability because biological barriers hinder their penetration. The oral absorption of peptides is low, only $1.6 \%$ of insulin (Mw: $5808 \mathrm{Da}$ ) and $1.4 \%$ of calcitonin (Mw: $3400 \mathrm{Da}$ ) become available systemically (Sarmento et al., 2007; Buclin et al., 2002). Not only molecular size, 
but solubility properties also strongly influence the absorption of drugs. Due to insufficient lipophilicity the partition into biological membranes of very hydrophilic, low-molecular weight agents is low resulting in unsatisfied permeability. However, the cellular uptake of highly lipophilic compounds is also hindered because they cannot dissolve in aqueous fluids in the body. For the optimum absorption, pharmaceuticals need both sufficient hydrophilicity to dissolve in aqueous fluids and adequate lipid solubility to facilitate their partitioning into the plasma membranes of cells. Molecular charge or hydrogen bonding groups also influence the permeability of drugs (Deák et al., 2006).

Biological barriers like the skin, the intestinal, blood-fetal or blood-brain barriers separate the organism from the external environment and the body compartments from each other. They control the transport of molecules, especially nutrients, and protect the organism from microbes and xenobiotics. Different barriers have different properties regarding to drug penetration therefore the bioavailability of pharmacons also depends on the site and mode of application. High drug utilization can be reached by injection into the blood or other local sites, but patient acceptance is low. Alternative non-invasive administration routes can be also effective, drug delivery through the nasal pathway can result in high and quick serum drug concentration elevation, similarly to intravenous injection (Kürti et al., 2013).

Since only the absorbed unbound drugs execute their effect on the body, drug interaction with plasma proteins (e.g. human serum albumin, globulin, glycoproteins) reduce the free drug concentration in blood, therefore the pharmacological availability (Oravcová et al., 1996). Finally, cellular, renal and hepatic metabolism and excretion to urine, feces, and bile decrease the drug content in the blood and eliminate it from the organs. Increasing the residence time by delayed release or lowering the metabolism by inhibiting enzyme activity can enhance the pharmacological utilization of drugs (Renukuntla et al., 2013). Understanding the factors contributing to the absorption and effectiveness of drugs (Fig. 1) helps to select pharmaco-technological approaches to improve bioavailability.

\section{Transport pathways across biological barriers}

Penetration of drugs across epithelial or endothelial barriers is mediated by several pathways, like passive diffusion, carrier or receptor mediated transport, and active efflux (Fig. 2). Passive penetration involves the diffusion of drugs in the direction of a concentration gradient, while carrier and receptor mediated transports move agents against concentration gradients (Sugano et al. 2010). The passive diffusion of pharmaceuticals through barriers can occur by combination of two pathways, the transcellular, across the cells, and paracellular routes, across the junctions between adjacent cells (Fig. 2). For lipophilic drugs the transcellular pathway is the major route due to their high affinity for the 
lipid bilayer of cell membrane. The transcellular penetration of hydrophilic molecules is blocked because they cannot interact with the lipid plasma membrane. At the paracellular pathway the permeability of drugs is modulated by tight junction (TJ) proteins which seal the gaps between cells. The transmembrane junctional proteins include the claudins, occludin, tricellulin, junctional adhesion molecules, and endothelial cell-selective adhesion molecule (Deli; 2009). They are anchored to the cytoplasmic filaments by scaffolding proteins like zonula occludens-1 or -2 (ZO-1; ZO-2) and dynamically modulated by several signaling pathways. The penetration of low molecular weight hydrophilic molecules at the paracellular route depends on the tightness of the intercellular junctions determined by the expression profile of junctional proteins and the lipid composition of the barrier (Deli, 2009).

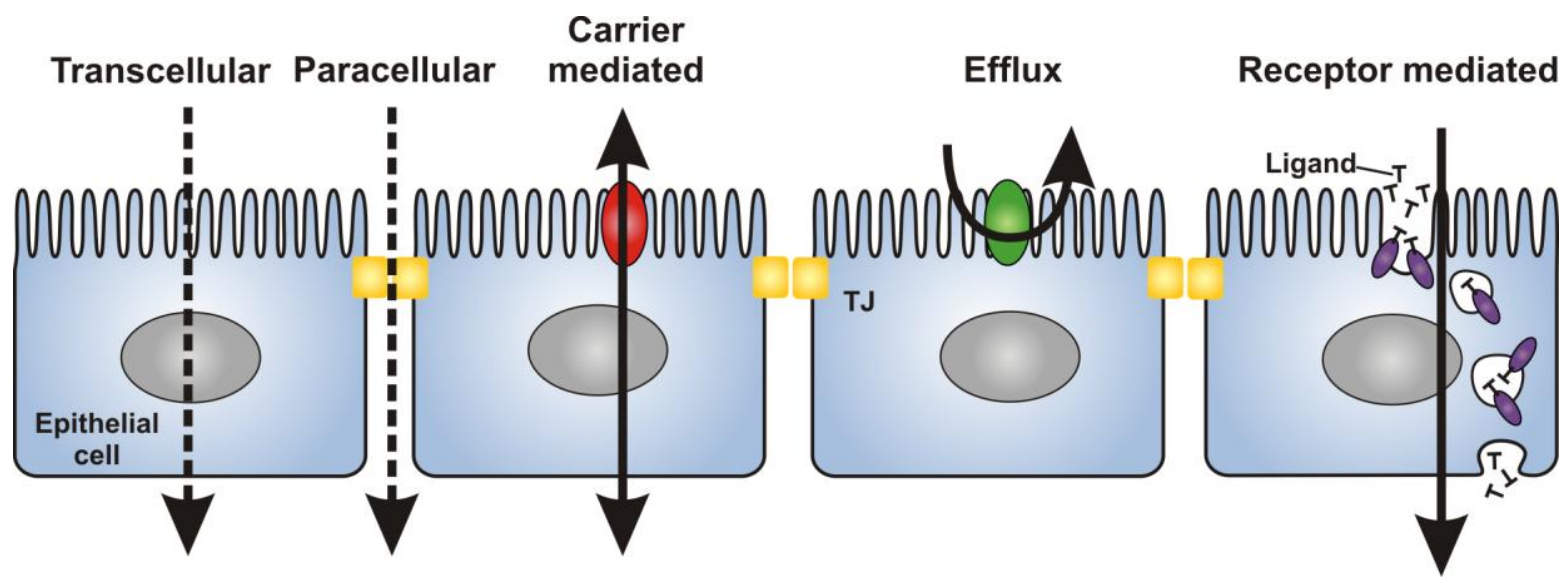

Figure 2. Transport pathways through the intestinal barrier. Red, SLC transporter; green, efflux transporter; purple: receptor

Membrane proteins greatly contribute to the transcellular permeation of drugs. There are more than 400 transporter proteins belonging to two major superfamilies of membrane transporters: the solute carrier (SLC) and ATP-binding cassette (ABC) transporter families. SLC uptake transporters are mainly co-transporters and many are driven by ion gradient. ABC transporters require ATP binding and hydrolysis for their function. Facilitated transport is driven by substrate gradient and involves a transporter protein, such as glucose or hexose transporter GLUT1. The carrier mediated transport is more selective for molecules, it is stereo and enantiospecific, in contrast to passive diffusion, where the physicochemical parameters are the main determinants rather than the conformation of molecules. Among SLC transporters about two dozen are related to drug disposition (Sugano et al., 2010). SLC influx transporters like OATP-A, PEPT1 or LAT1 can enhance the uptake of active molecules (Giacomini et al., 2010). LAT1 amino acid transporter delivers L-DOPA a neurotransmitter prodrug (Peura et al., 2013), and the antibiotic ampicillin is a substrate of PEPT1 peptide transporter (Lafforgue et al., 2008). ABC efflux 
transporters such as P-glycoprotein (Pgp), breast cancer resistance protein (BCRP), or multidrug resistance-associated protein-1, -2, -3 (MRP1-3) transporters are important members of the defense system against xenobiotics providing chemical immunity for the body (Schinkel et al., 2003). They also recognize and eliminate a wide range of different drugs, especially at the level of the blood-brain and intestinal barriers, the kidney and the liver (Giacomini et al., 2010). Receptors are also suitable to deliver large molecules, including recombinant proteins and peptides through barriers via receptor mediated transport (Pardridge, 2012). It is worth noting that the passive and carrier mediated drug transports coexist and that the passive permeation is a significant factor in the absorption of drug-like molecules (Sugano et al., 2010).

\subsection{Drug transport across the intestinal barrier}

The different biological properties of epithelial and endothelial barriers determine drug permeability which can differ greatly (Ward et al., 2000). Transepithelial resistance (TEER) reflects the paracellular ion flux through barriers and indicates their tightness. The strongest barriers in the body are formed by brain capillaries and skin epithelial cells (Deli, 2009). The mucous layer of the gastrointestinal (GI) tract represents an intermediate tightness with highly variable barrier properties in individual anatomical parts. Small intestine, where the majority of nutrient uptake occurs, possesses the lowest resistance values reflecting leaky barrier, while colon have intermediate tightness. Because the main focus of this work is improving drug delivery across the intestinal barrier, only this biological barrier is discussed in detail.

Oral drug delivery is the most popular mode for treating diseases. It is safe, efficient, and patient compliance is good. However, drug absorption is restricted by TJs connecting intestinal epithelial cells. Cell membrane permeability is a major determinant of drug penetration (Aungst, 2012; Sugano et al., 2010), but paracellular transport also has a big impact on drug penetration (Deli, 2009). The extent of drug absorption greatly differs between regions of the GI tract due to dissimilar anatomical structures, distinct lipid composition of cellular membranes, and different expression pattern of TJ proteins (Chiba et al., 2008) and uptake and efflux transporters (Renukuntla et al., 2013; Deli, 2009). The jejunum and ileum shows the highest drug absorption rate because of more permeable TJs compared with other parts of the GI tract (Ward et al., 2000). Furthermore, microvilli in the apical part of epithelial cells multiply the absorptive surface area of small intestine two to four-folds compared to colon (Masaoka et al., 2006). The major limitations of the per os administration route include the acidic environment and enzymes in the stomach, which degrade sensitive molecules, especially peptide or protein based drugs (Renukuntla et al., 
2013). Drugs absorbed from the small and large intestines enter into the portal vein and reach the liver where the active agents can be metabolized by the hepatobiliary system further lowering drug bioavailability.

\subsection{Models for the prediction of intestinal drug absorption}

It is crucial to assess the permeability properties of new active agents or drug candidates in the early phase of drug development (Vastag et al., 2009). There are several models for the prediction of intestinal drug absorption (Fig. 3). In silico screening is a rapid, cheap and high throughput method, but at present it cannot give accurate predictions for transporters (Vastag et al., 2009; Deli, 2011). In vitro methods, like the octanol-water partitioning or the parallel artificial membrane penetration assay (PAMPA) are also suitable for screening permeability based on the physicochemical properties of drugs.

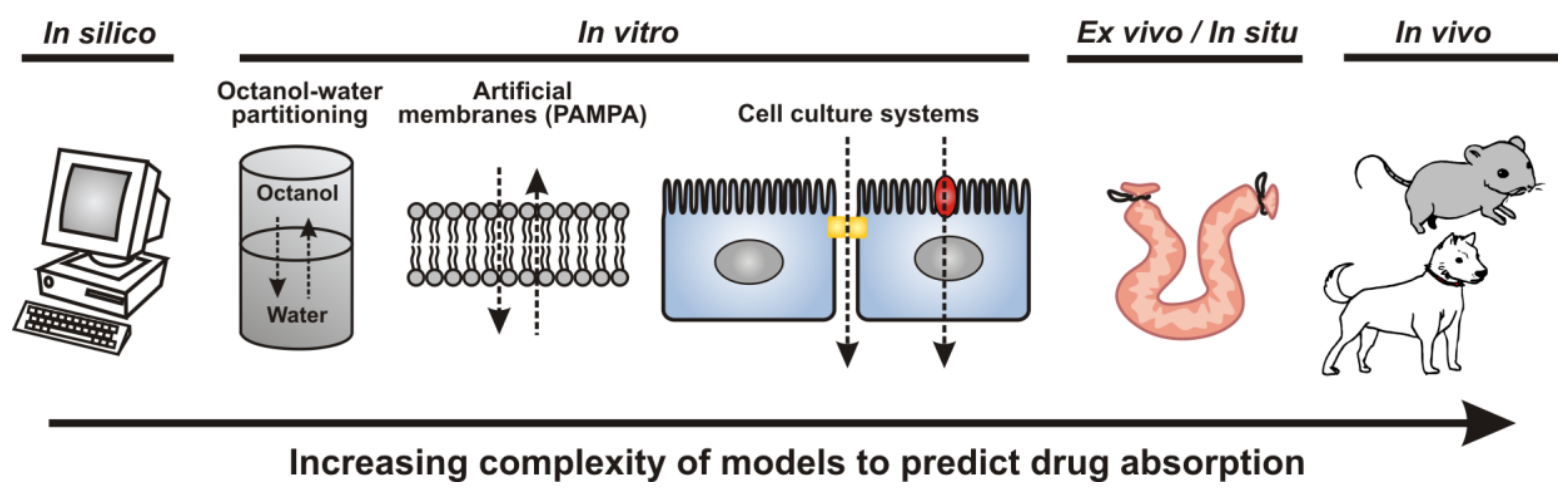

Figure 3. Models for the prediction of intestinal drug absorption

In vitro cell culture assays are screening systems with higher complexity. Epithelial cell lines, such as the human Caco- 2 model are better alternatives for predicting intestinal drug absorption and are routinely used in drug development (Artursson et al., 1997). They express many SLC and ABC transporters therefore they are suitable to test carrier mediated and active efflux transport as well. The Caco-2 cell line (Fig. 4) is a well characterized model of the epithelium of small intestine (Hubatsch et al., 2007). Cells are polarized, grow in monolayer, possess microvilli, make tight connections with adjacent cells and express many nutrient and efflux transporters such as P-gp (Artursson et al., 2001; Englund et al., 2006). Caco- 2 cells are widely used to measure drug penetration and data correlate well with in vivo drug absorption, mostly in case of passive transcellular pathway (Artursson et al., 2001; Hellinger et al., 2010). Furthermore, the Caco-2 model is approved by the Food and Drug Administration for the identification of P-gp substrates (FDA Guidance for Industry, Drug Interaction Studies, 2012). Caco-2 cells selected by vinblastine show more uniform 
cell morphology, express higher level of P-gp than native Caco-2 cells, and are excellent for screening efflux pump ligands (Hellinger et al., 2010).
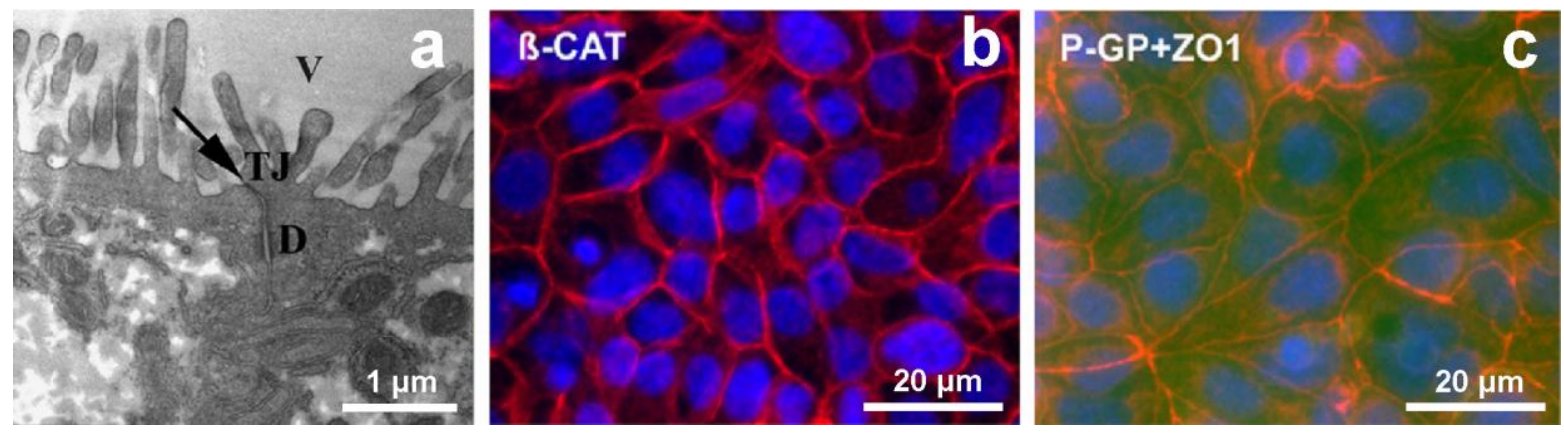

Figure 4. Images of vinblastine selected Caco-2 cells (Hellinger et al., 2012): (a) Electronmicrograph of Caco-2 cells showing a tight junction (arrow); (b) immunostaining for $\beta$-catenin adherens junction protein (red); (c) immunostaining for P-glycoprotein efflux pump (green) and ZO-1 tight junction linker protein (red). $\beta$-CAT, $\beta$ catenin; D, desmosome; P-GP, P-glycoprotein; TJ, tight junction; V, villus ;ZO1, Zonula occludens protein-1.

Ex vivo or in situ models, such as everted sac, Ussing chamber and intestinal perfusion methods use intact tissue from laboratory animals and are also applied for drug investigation. These more complex intestinal models can better predict drug absorption than in vitro PAMPA or cell culture techniques, but they are more complicated and expensive. In vivo animal studies are also widely used, mainly in the last stage of drug development.

\subsection{Absorption enhancers}

Agents with low permeability may need assistance for their penetration through barriers. Absorption enhancers are compounds that improve the absorption of drugs and enhance their bioavailability. An optimal enhancer should possess the following characteristics: safe and non-toxic, chemically and pharmacologically inert, non-irritant, non-allergenic, outstanding and reversible permeation enhancement (Renukuntla et al., 2013). These essential factors determining the success of permeation enhancers are in the focus of in-depth investigations for the pharmaceutically used and novel absorption enhancers.

\section{Methods to increase intestinal drug delivery}

Intestinal absorption enhancers can improve the pharmacological utilization of drugs by several mechanisms: (i) increasing drug solubility; (ii) opening the tight junctions; (iii) temporarily disturbing the lipid bilayer packing or fluidizing membranes; (iv) complexation or ion pairing; (v) preventing degradation/metabolism (Fig. 5; Renukuntla et al., 2013; Aungst, 2012). 


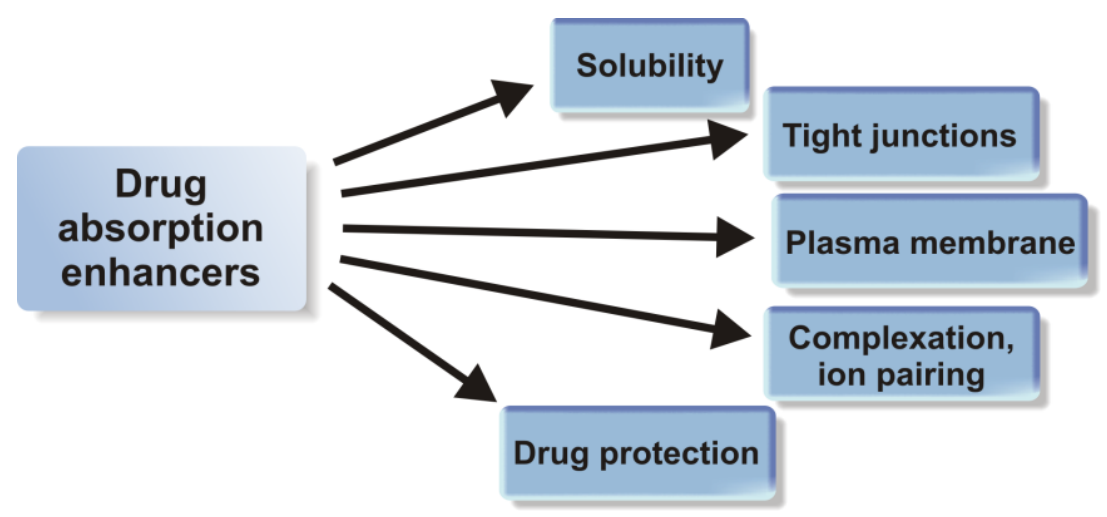

Figure 5. Effects of absorption enhancers

Solubilization of drugs increases the dissolved molecules and the distributions of drugs in the liquids. Molecular form of active agents cross barriers or penetrate cells better. There are many well characterized and effective excipients in pharmaceutical technology for solubilizing lipophilic pharmacons, like surfactants, fatty acids or cyclodextrines (Strickley, 2004). They enhance the dissolution of drugs, like the immunosuppressant cyclosporin A, antineoplastic paclitaxel or etoposide, and antiviral lopinavir or ritonavir, resulting in higher bioavailability.

A wide variety of compounds show TJ modulator properties, such as surfactants, chelators, cationic polymers, nitric oxide donors, bacterial toxins, or peptides (Deli, 2009). They reversibly open intracellular junctions and increase the paracellular flux of molecules. Modulators can directly act on TJ proteins and open the intercellular cleft, like the non-toxic peptide fragments of Clostridium perfringens enterotoxin (Sonoda et al., 1999). Cyclodextrines (Kiss et al., 2007) or cationic chitosans (Smith et al., 2005) indirectly modulate TJs. Anionic-, ionic-, non-ionic surfactants or bile salts were extensively studied to enhance transepithelial permeability, but their effects on TJs were less characterized. Transcellular permeation enhancement requires the modification of plasma membranes. Surfactants acting as absorption enhancers partition into epithelial cell membranes and change the packing of lipids (Swenson and Curatolo, 1992). Bile salts, like sodium cholate or taurocholate increase transcellular permability by changing the lipid composition of membranes. Complex formation or ion pairing also enhance the cellular permeability of drugs; lipophilic cyclodextrins such as the methylated derivatives (Loftsson et al., 2007), or counter-ion and drug pairs like 1-hydroxy-2-naphtoic acid and guanidino oseltamivir (Miller et al., 2010) help the encapsulated or linked drugs to cross the plasma membrane of cells.

Degradation or metabolism of pharmacons might be prevented by encapsulation to protect against intestinal enzymes or by the $\mathrm{pH}$-dependent controlled release of drugs. Surfactants are suitable to encapsulate and protect pharmacons, because above critical 
micellarization concentration (CMC) they self-aggregate in defined orientation and form micelles (Narang et al., 2007).

\subsection{Non-ionic surfactants as drug absorption enhancers}

Surface active agents, or surfactants, are amphiphilic molecules possessing both lipophilic and hydrophilic residues. They are grouped by their physicochemical properties as anionic, cationic, non-ionic and zwitterionic surfactants. Anionic and non-ionic surfactants are the most applied excipients in the pharmaceutical industry and they are widely used as solubilizing agents in oral, injectable and nasal formulations (Table 1; Strickley, 2004; Dredán et al., 1998; Fedina et al., 1998). Many studies reviewed their absorption enhancer properties (Ganem-Quintanar et al., 1997; Aungst, 2012); they mostly increase the permeability through transcellular routes (Aungst, 2012), but there are data on their effect on TJs (Deli, 2009).

\begin{tabular}{|c|c|c|c|}
\hline Non-ionic surfactant & Drug & Trade name & Classification \\
\hline Cremophor RH & Cyclosporine A & Neoral & Immunosuppressant \\
\hline \multirow{2}{*}{ Cremophor EL } & $\begin{array}{c}\text { Paclitaxel } \\
\text { Ritonavir }\end{array}$ & $\begin{array}{c}\text { Taxol } \\
\text { Norvir }\end{array}$ & $\begin{array}{c}\text { Antineoplastic } \\
\text { Antiviral (HIV) }\end{array}$ \\
\hline \multirow{2}{*}{ Tween 80 } & $\begin{array}{c}\text { Cyclosporine A } \\
\text { Sirolimus } \\
\text { Etoposide }\end{array}$ & $\begin{array}{c}\text { Genraf } \\
\text { Rapamune } \\
\text { VePesid }\end{array}$ & $\begin{array}{c}\text { Immunosuppressant } \\
\text { Immunosuppressant } \\
\text { Antineoplastic }\end{array}$ \\
\hline TPGS & Amprenavir & Agenerase & Antiviral (HIV) \\
\hline Solutol HS-15 & Diclofenac & - & NSAID \\
& Propanidid & Panitol & General anestethic \\
\hline
\end{tabular}

Table 1. Examples for non-ionic surfactants in commercially available oral or injectable formulations (Strickley, 2004). Abbrevation: HIV, human immunodeficiency virus; NSAID, non-steroidal anti-inflammatory drug

Chemically non-ionic surfactants include derivatives of ethylene oxide or propylene oxide with alcohols, alkyl phenols, sucrose esters, and fatty acids. These surfactants, widely studied in pharmaceutical research, possess advantageous properties and many of them are used in commercially available drug formulation for decades (Table 1). Non-ionic surfactants are generally recognized as safe (Williams and Barry, 2004). This goup of excipients are good solubilizers of drugs (Strickley, 2004), have absorption enhancer properties (Aungst, 2000), and some of them were described as efflux pump inhibitor (Cornaire et al., 2004; Nerurkar et al., 1997). 


\section{Cremophors}

Chremophor, or as recently renamed Kolliphor, is a family of ionic and non-ionic emulsifiers and a registered trademark of BASF SE (Ludwigshafen, Germany). In pharmaceutical research and industry Cremophor EL, RH40 and RH60, ethoxylated derivatives of castor oil, are the most often used excipients (Fig. 5).
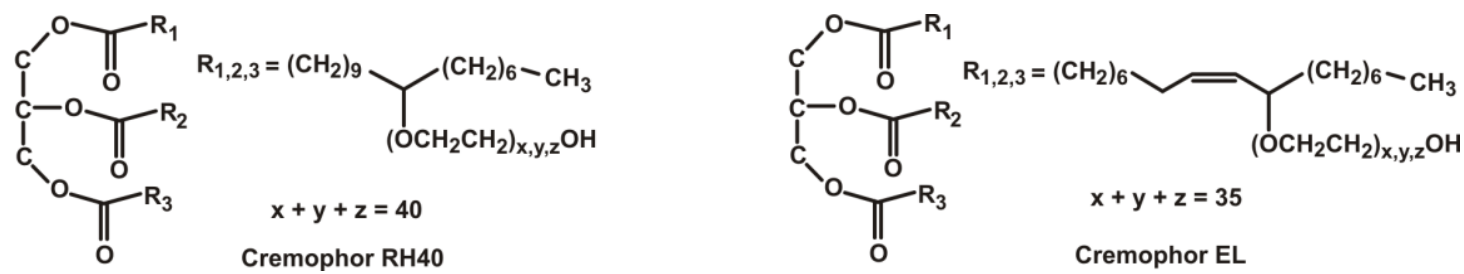

Figure 5. Chemical structure of Chremophor RH40 and EL

Cremophor RH40 (Table 1 and 2) is used in oral formulations, such as in Neoral (Novartis, East Hanover, NJ), in microemulsions (Cao et al., 2011), in self-emulsifying drug delivery systems (Gursoy and Benita, 2004), and in buccoadhesive tablets (Sakeer et al., 2010). Cremophor RH40 in transdermal systems enhances the absorption of ketoprofen (Rhee et al., 2001) and theophylline (Zhao et al., 2006). It was also used as an absorption enhancer in nasal formulations in our previous research (Horvát et al., 2009). Cremophor EL (Fig. 5; Table 1 and 2) is used in infusions (Taxol), oral capsules (Gengraf), as well as in solutions. It is a well known solubilizer and penetration enhancer (Flaten et al., 2008), moreover inhibition of efflux pumps by Cremophor EL was also described (Nerurkar et al., 1997).

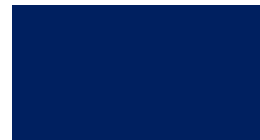

Trade name

Chemical name

R- carbon chain lenght

HLB CMC

Solubility
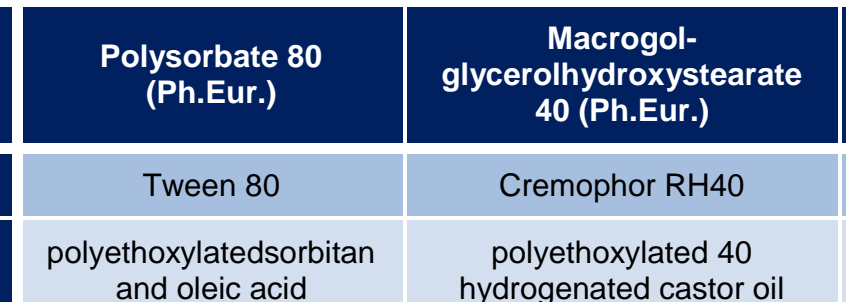

polyethoxylated 40 hydrogenated castor oil

\begin{abstract}
Tween 80
\end{abstract}
polyethoxylatedsorbitan

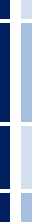
and oleic acid

\begin{tabular}{|c|} 
and oleic acid \\
18 \\
\hline
\end{tabular}

15

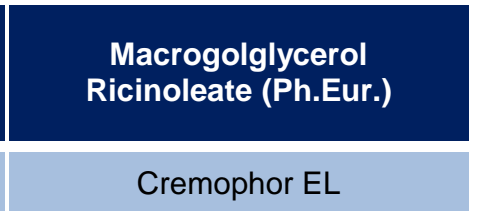

Cremophor EL

polyoxyl 35 castor oil

\begin{tabular}{|c|c|c|}
\hline & 15 & $12-14$ \\
\hline $50-63 \mu \mathrm{g} / \mathrm{ml}^{1,2}$ & $390 \mu \mathrm{g} / \mathrm{ml}^{3}$ & $100 \mu \mathrm{g} / \mathrm{ml}^{3}$ \\
\hline water soluble & water soluble & water soluble \\
\hline
\end{tabular}

Table 2. Properties of Tween 80 and Cremophor RH40 and Cremophor EL. Abbreviation: CMC, critical micellarization concentration; HLB, hydrophilic-lipophilic balance; Ph.Eur., European Pharmacopoeia. ${ }^{1}$, Nerurkar et al., 1997; ${ }^{2}$, Christiansen et al., 2010; ${ }^{3}$,Christiansen et al., 2011 
During the clinical application of Cremophor EL containing infusions side effects were observed and there are efforts to find solubilizers and absorption enhancers with better profile (Gelderblom et al., 2001).

\section{Tweens}

Tweens, also known as polysorbates, are hydrophilic emulsifying agents and used by food, cosmetic and pharmaceutical industry. It is a group of ethoxylated sorbitan fatty acids. Tween 80 (Fig. 6 and Table 2) is commonly used as wetting, solubilizing and emulsifying agent in immediate-release solid and liquid dosage forms (Dredan et al., 1998). It can also act as an absorption enhancer. The permeability of cimetidine, furosemide, ranitidine hydrochloride, hydrochlorothiazide, and a model peptide was significantly increased by Tween 80 through Caco-2 cells (Rege et al., 2001, Nerurkar et al., 1997). Digoxin uptake was enhanced by Tween 80 in an ex vivo model (Cornaire et al., 2004). Tween 80 inhibits Pgp efflux transporter (Nerurkar et al., 1997).

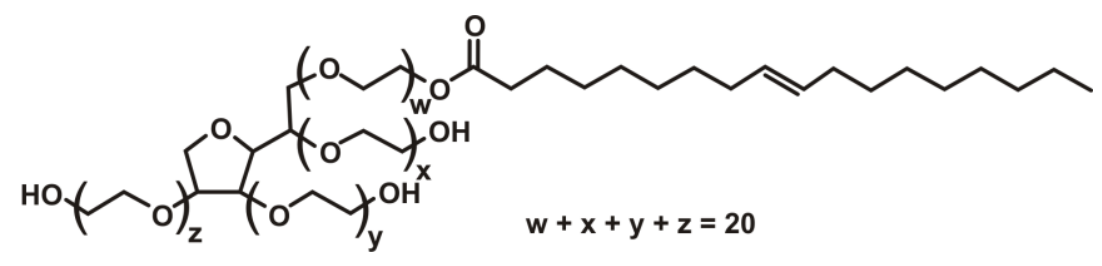

Figure 6. Chemical structure of Tween 80

\section{Sucrose fatty acid esters}

Sucrose esters, composed of sucrose and fatty acids, are natural molecules produced by plants and microorganisms (Table 3; Daudé et al., 2012). Their potential application for drug delivery as solubilizers and stabilizer or absorption enhancers is widely researched. Sucrose esters were successfully tested in many different formulations like in suspensions (Yokoi et al., 2005), microemulsions (Thevenin et al., 1996), elastic vesicles (Honeywell-Nguyen et al., 2003), nanoemulsions (Klang et al., 2011). Due to their excellent solubilizing properties they increase the dissolution of a wide variety of drugs resulting higher bioavailability (Szüts et al., 2012).

As absorption enhancers sucrose esters were mainly investigated for transdermal delivery (Csóka et al., 2007), but there are studies for oral, nasal and ocular applications as reviewed by Szüts and Szabó-Révész (2012). Investigating their permeability enhancer properties for intestinal drug delivery, sucrose fatty acid esters significantly increased the absorption of daunomycin, calcitonine, lidocain hydrochloride, cyclosporine A, and dextran in cell cultures or animal studies (Takaishi et al., 2006; Nakada et al., 1988; Ganem-Quintanar et al., 1998; Lerk et 
al., 1993; Onishi et al., 2012). Sucrose esters were also described as efflux pump inhibitors but results are contradictory. Their effects on P-glycoprotein were tested in epithelial cells and in animal experiments (Cornaire et al, 2010; Hanke et al., 2004), but Takaishi et al. (2006) suggested that they do not inhibit efflux pumps.

\begin{tabular}{|c|c|c|c|}
\hline & P-1695 & M-1695 & D-1216 \\
\hline $\begin{array}{l}\text { Chemical } \\
\text { structure }\end{array}$ & $\stackrel{\mathrm{R}-\mathrm{CO}}{\mathrm{H}}$ & O-R & $\mathrm{H}_{2} \mathrm{O}-\mathrm{R}$ \\
\hline Trade name & Ryoto sugar ester P-1695 & Ryoto sugar ester M-1695 & $\begin{array}{c}\text { Surfhope SE Pharma D- } \\
1216 \text { (US DMF) }\end{array}$ \\
\hline $\begin{array}{l}\text { Chemical } \\
\text { name }\end{array}$ & palmitate sucrose ester & myristate sucrose ester & laurate sucrose ester \\
\hline $\begin{array}{l}\text { R- carbon } \\
\text { chain lenght }\end{array}$ & 16 & 14 & 12 \\
\hline HLB & 16 & 16 & 16 \\
\hline CMC & $28-250 \mu \mathrm{M}^{1}$ & $28-250 \mu \mathrm{M}^{1}$ & $500 \mu \mathrm{g} / \mathrm{ml}^{2}$ \\
\hline Solubility & water soluble & water soluble & water soluble \\
\hline
\end{tabular}

Table 3. Properties of sucrose fatty acid esters. Abbreviation: CMC, critical micellarization concentration; HLB, hydrophilic-lipophilic balance; Ph.Eur., European Pharmacopoeia. ', Molinier et al., 2005; ' , Christiansen et al., 2010; ${ }^{3}$,Christiansen et al., 2011

\subsection{Aims}

The main aim of the work was to reveal the complex mechanisms of the effect of nonionic surface active agents, especially water soluble sucrose esters on drug penetration across the intestinal barrier using culture models. Three selected sucrose esters, potential novel pharmaceutical excipients, were compared to Tween 80, Cremophor RH40 and Cremophor EL, reference surfactants, used in various medicinal products. The major aims of the experimental study were the following:

(I) investigation and comparison of the effects of surfactants on intestinal epithelial and vascular endothelial cell viability

(II) measurement of the effects of surfactants on drug permeability

(III) identification of the pathways for the drug penetration enhancement on intestinal barrier model

(IV) detailed analysis of intercellular tight junction morphology and membrane fluidity

(V) determination of the effects of surfactants on efflux pump activity 


\section{MATERIALS AND METHODS}

\subsection{Materials}

All reagents were purchased from Sigma-Aldrich Ltd. (Budapest, Hungary), unless otherwise indicated. Laurate sucrose ester (D-1216) was of pharmaceutical grade, palmitate (P1695) and myristate (M-1695) sucrose esters were of analytical grade (Mitsubishi Kagaku Foods Co., Tokyo Japan). Tween 80, Cremophor RH40 and Cremophor EL (BASF, Ludwigshafen am Rhein, Germany) were of pharmaceutical grade and used as reference surfactants. Buffers used in the experiments were: phosphate buffer saline (PBS) $\left(136 \mathrm{mM} \mathrm{NaCl}, 6.5 \mathrm{mM} \mathrm{Na} \mathrm{HPO}_{4}\right.$, $2.7 \mathrm{mM} \mathrm{KCl}, 1.5 \mathrm{mM} \mathrm{KH}_{2} \mathrm{PO}_{4}$ ); Ringer-Hepes buffer (150 mM NaCl, $6 \mathrm{mM} \mathrm{NaHCO} 3,5.2 \mathrm{mM}$ $\mathrm{KCl}, 2.2 \mathrm{mM} \mathrm{CaCl}$, $0.2 \mathrm{mM} \mathrm{MgCl}$, $2.8 \mathrm{mM}$ D-glucose, 5 mM Hepes, $\mathrm{pH}$ 7.4).

\subsection{Cell culture}

Caco-2 Human intestinal epithelial cell line (ATCC cat.no. HTB-37, USA), human hCMEC/D3 brain endothelial cell line (Weksler et al. 2013), human uterine sarcoma lines MES-SA and its doxorubicin-selected derivative MES-SA/Dx5, and primary rat brain endothelial cells were used in the experiments. Caco-2 cells were grown in Eagle's minimal essential medium (Gibco, Life Technologies, Carlsbad, CA, USA) supplemented with $10 \%$ fetal bovine serum (Lonza, Basel, Switzerland), 1\% sodium-pyruvate (Gibco, Life Technologies, Carlsbad, CA, USA) and $50 \mu \mathrm{g} / \mathrm{ml}$ gentamicin in a humidified $37^{\circ} \mathrm{C}$ incubator with $5 \% \mathrm{CO}_{2}$. To obtain a more uniform morphology and higher efflux pump expression cells were treated with vinblastine $(10 \mathrm{nM})$ for at least 6 passages as described by Hellinger et al. (2010 and 2012). D3 cells were grown in Endothelial Basal Medium-2 containing Endothelial Growth Medium-2 BulletKit (Lonza, Basel, Switzerland) supplemented with $2.5 \%$ fetal bovine serum in a humidified $37^{\circ} \mathrm{C}$ incubator with $5 \% \mathrm{CO}_{2}$. Primary cultures of brain endothelial cells were isolated from 3-weeks-old rats described by Veszelka et al. (2007). Cells were seeded in culture dishes at a density of $5 \times 10^{4}$ cells $/ \mathrm{cm}^{2}$ and the medium was changed every 2 days. When cells reached approximately 80-90\% confluence in the dish they were subcultured with $0.05 \%$ trypsin-EDTA solution. For electric resistance measurements, permeability studies and electron microscopy Caco-2 cells were cultured on Transwell inserts (polycarbonate membrane, $0.4 \mu \mathrm{m}$ pore size, $1.12 \mathrm{~cm}^{2}$ surface area, Corning Life Sciences, Tewksbury, MA, USA). For staining of nuclei, junctions and F-actin cells were grown on glass coverslips (Menzel-Gläser, Braunschweig, Germany). Surfaces were coated with $0.05 \%$ rat tail collagen before cell seeding, unless otherwise indicated. 
Human uterine sarcoma lines MES-SA, and its doxorubicin-selected derivative expressing high levels of P-gp (MES-SA/Dx5) were used for testing P-gp functionality (Chen et al., 1994). Cells were grown in Dulbecco's Modified Eagle Medium (DMEM; Gibco, Life Technologies, Carlsbad, CA, USA) supplemented with $10 \%$ fetal bovine serum, $5 \mathrm{mM}$ L-glutamine and 50 $\mathrm{u} / \mathrm{ml}$ penicillin/streptomycin. To maintain homogenous P-gp expression, MES-SA/Dx5 cells were treated with $500 \mathrm{nM}$ doxorubicin for at least 2 passages before the experiments.

\subsection{In vitro viability studies}

Different methods were applied to determine the effects of non-ionic surfactants on cell viability: MTT dye conversion, lactate dehydrogenase release (LDH) measurement, double fluorescent staining of cell nuclei. Real-time cell impedance measurement also provided information on cell viability.

\subsubsection{Treatment concentrations and intervals}

The treatment concentrations of sucrose esters P-1695, M-1695 and D-1216 varied between 3-3,000 $\mu \mathrm{g} / \mathrm{ml}$. Tween 80, Cremophor RH40 and Cremophor EL were used in 1$100,000 \mu \mathrm{g} / \mathrm{ml}$ concentrations. All treatment solutions were prepared or diluted in DMEM without phenol red. Untreated cells (control group) received only culture medium. Triton X$100(10 \mathrm{mg} / \mathrm{ml})$ was used as a toxicity control. The cells were treated for 1 and 24 hours.

\subsubsection{MTT dye conversion}

The yellow 3-(4,5-dimethyltiazol-2-yl)-2,5-diphenyltetrazolium bromide (MTT) dye is taken up by cells and converted by mitochondrial and cytoplasmic enzymes into blue formazan crystals (Fig. 7, Liu et al. 1997). The dye conversion rate determines cell metabolic activity and viability. Caco-2 epithelial and hCMEC/D3 endothelial cells were cultured in 96-well plates (Orange Scientific, Braine-1'Alleud, Belgium) for 3 days. Confluent cultures were treated and incubated with surfactants for 1 and 24 hours. Then cells were washed with PBS and incubated with $0.5 \mathrm{mg} / \mathrm{ml}$ MTT solution in phenol red free DMEM for 3 hours in a $\mathrm{CO}_{2}$ incubator. The amount of formazan converted by cells was dissolved in dimethylsulfoxide (DMSO) and determined by measuring absorbance at $595 \mathrm{~nm}$ wavelength with a microplate reader (Fluostar Optima, BMG Labtechnologies, Ortenberg, Germany). Cell viability was calculated as percentage of dye conversion by non-treated cells. 


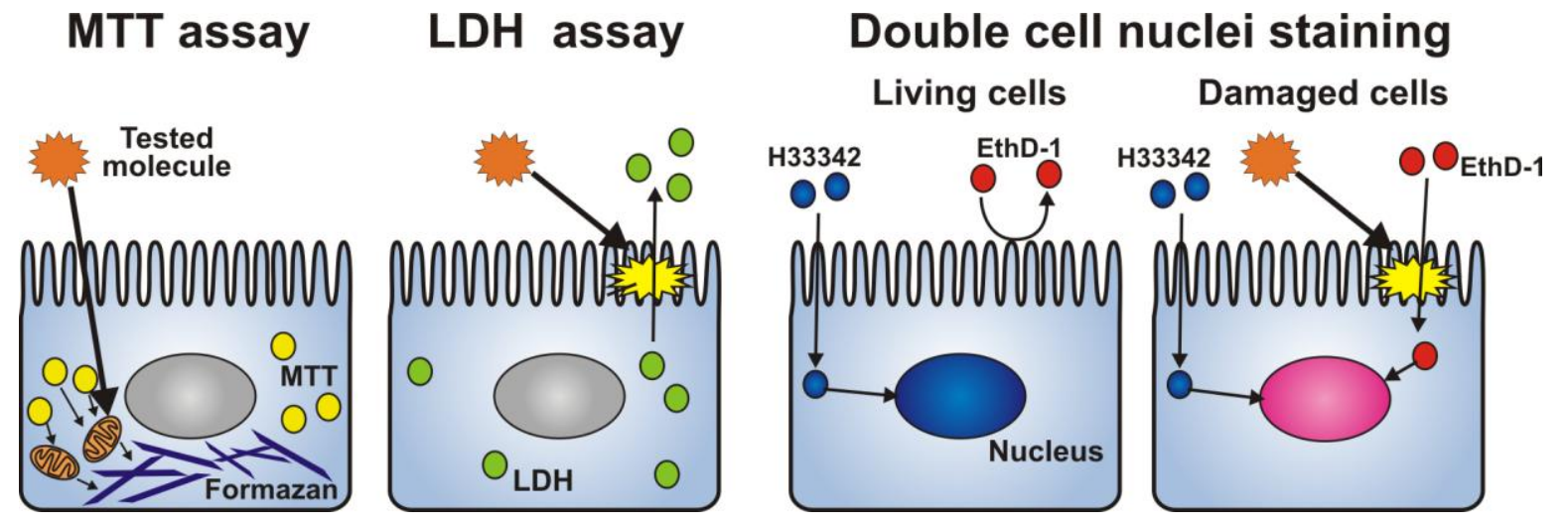

Figure 7. Cell viability assays: MTT dye conversion, LDH release measurement, and double fluorescent cell nuclei staining. Abbreviations: LDH, lactate dehydrogenase; H33342, Bis-Benzimide; EthD-1, ethidium homodimer-1; yellow star: membrane damage

\subsection{3. $\mathrm{LDH}$ release measurement}

The release of LDH enzyme, the indicator of cell membrane damage (Fig. 7), was determined from culture supernants by Cytotoxicity Detection Kit/LDH (Roche, Basel, Switzerland). Caco-2 or hCMEC/D3 cells were cultured in 96-well plates for 3 days then treated for 1 or 24 hours with surfactants. After treatments $50 \mu$ samples from culture supernatants were incubated with equal amounts of reaction mixture for 15 minutes. The enzyme reaction was stopped by $0.1 \mathrm{M} \mathrm{HCl}$. Absorbance was measured at a wavelength of $492 \mathrm{~nm}$ with a microplate reader (Fluostar Optima, BMG Labtechnologies, Ortenberg, Germany). Cell death was calculated as percentage of the total LDH release from cells treated by Triton X-100. The non-toxic concentrations (TC0), $50 \%$ toxic concentrations (TC50) and concentrations causing death in all cell (TC100) were calculated from fitted curves (GraphPad Prism 5.0, GraphPad Software Inc., San Diego, CA, USA). The detailed description of calculation is shown in Appendix (Pub. III, Supporting Information Eq. 1-2).

\subsubsection{Double fluorescent staining of cell nuclei}

Cell viability was also determined by a morphological test: bis-benzimide (Hoechst 33342) labels all cell nuclei blue, ethidium-homodimer-1 (Molecular Probes, USA) stains only dead cells red (Fig. 7). Caco-2 and primary rat brain endothelial cells grown on glass coverslips were treated with Cremophor RH40 and EL for 1 and 24 hours. Thirty minutes before the end of treatments $10 \mu \mathrm{M}$ bis-benzimide and ethidium-homodimer- 1 were added to the cells. Cells were fixed in $4 \%$ paraformaldehyde in PBS, and processed for TJ immunostaining. At the end of immunostaining coverslips were mounted by Fluoromount. The fluorescent stainings of epithelial cells were detected by Leica SP5 confocal microscope (Leica Microsystems CMS GmbH, Germany). Stainings of primary brain endothelial cells 
were examined by a NikonEclipse TE2000 fluorescent microscope (Nikon, Japan) and photographed by a Spot RT digital camera (Diagnostic Instruments, USA).

\subsection{Fluorescent actin-labeling and immunostainings for junctional proteins}

Treatments induced changes in morphology and cell-cell connections of Caco-2 cells were confirmed by immunostaining for tight junction proteins claudin- 1 and -4 , cytoplasmic linker protein ZO-1 and adherens junction protein $\beta$-catenin. Filamentous actin (F-actin) was stained in intestinal culture model by fluorescently labeled phalloidin and cell nuclei by bisbenzimide dye. The morphology of TJ was also investigated in primary rat brain endothelial cells by immunostaining for claudin-5 protein. Cell layers were grown on glass coverslips and treated with absorption enhancers (P-1695 $30 \mu \mathrm{g} / \mathrm{ml}, \mathrm{M}-169560 \mu \mathrm{g} / \mathrm{ml}, \mathrm{D}-1216$ $100 \mu \mathrm{g} / \mathrm{ml}$, Tween $801000 \mu \mathrm{g} / \mathrm{ml}$, Cremophor RH40 $1000 \mu \mathrm{g} / \mathrm{ml}$ or Cremophor EL $1000 \mu \mathrm{g} / \mathrm{ml}$ ) for 1 hour. Cytochalasin D, an inhibitor of actin polymerization was applied at $2 \mu \mathrm{g} / \mathrm{ml}$ concentration. After treatments the cultures were washed twice in PBS and fixed with $4 \%$ paraformaldehyde-PBS for 30 minutes. Cells were permeabilized with $0.2 \%$ Triton X-100 and blocked with $3 \%$ bovine serum albumin-PBS. Cells were washed three times with PBS between each step. The fixed cells were incubated with primary antibodies anti-claudin-1, anti-claudin-4, anti-claudin-5, anti-ZO-1 or anti- $\beta$-catenin (Life Technologies, Carlsbad, CA, USA) overnight. Incubation with secondary antibody Cy3labeled anti-rabbit IgG, and Alexa Fluor 488 Phalloidin (Life Technologies, Carlsbad, CA, USA) and bis-benzimide lasted for 1 hour. Between and after incubations cells were washed three times with PBS. Coverslips were mounted by Fluoromount. Stainings for claudin-1, claudin-4, ZO-1and $\beta$-catenin were examined by a Leica SP5 confocal microscope, while claudin-5 stainings were detected by a NikonEclipse TE2000 fluorescent microscope and photographed by a Spot RT digital camera.

\subsection{Electron microscopy}

Cells grown on culture inserts were treated with absorption enhancers (P-1695 $30 \mu \mathrm{g} / \mathrm{ml}$, M-1695 $60 \mu \mathrm{g} / \mathrm{ml}, \mathrm{D}-1216100 \mu \mathrm{g} / \mathrm{ml}$, Tween 80 and Cremophor RH40 $1000 \mu \mathrm{g} / \mathrm{ml}$ ) for 1 hour. After treatments cells were washed by PBS and fixed with $3 \%$ paraformaldehyde containing $0.5 \%$ glutaraldehyde in cacodylate buffer $(\mathrm{pH} 7.4)$ for $30 \mathrm{~min}$ at $4^{\circ} \mathrm{C}$. After washing with the buffer several times, cells were postfixed in $1 \% \mathrm{OsO}_{4}$ for $30 \mathrm{~min}$. Following a rinse with distilled water, the cells were dehydrated in graded ethanol, block-stained with $1 \%$ uranyl acetate in $50 \%$ ethanol for $1 \mathrm{~h}$. After the last step of dehydration, inserts were placed in the 1:1 
mixture of ethanol and Taab 812 (Taab; Aldermaston, Berks, UK) for $30 \mathrm{~min}$ at $30^{\circ} \mathrm{C}$. Finally, the membranes of the culture inserts with the cells were removed from their support and embedded in Taab 812. Polymerization was performed overnight at $60^{\circ} \mathrm{C}$. Ultrathin sections were cut perpendicularly for the membrane using a Leica UCT ultramicrotome (Leica Microsystems, Milton Keynes, UK) and examined using a Hitachi 7100 transmission electron microscope (Hitachi Ltd., Tokyo, Japan)

\subsection{Impedance measurement}

Measurement of the impedance dynamically monitors living cells. The RTCA SP instrument (ACEA Biosciences, San Diego, USA) measures impedance at $10 \mathrm{kHz}$, which derives from interaction between cells and electrodes of 96-well E-plates (ACEA Biosciences). This interaction correlates with cell proliferation, viability or with transcellular ion flux in real-time (Fig. 8; Atienza et al. 2006; Ózsvári et al., 2010; Benson et al., 2013). Background readings were performed before cell seeding, then cells were dispensed at the density of $1 \times 10^{4}$ cells/well, and grown until confluency. Impedance was measured every 2 minutes following treatments. For ion flux measurement the impedance at each time point was defined as $R_{n}-R_{b}$. For the toxicity measurement of Cremophors cell index at each time point was calculated from the following equation: $\left(R_{n}-R_{b}\right) / 15$, where $R_{n}$ is the cell-electrode impedance of the well when it contains cells and $R_{b}$ is the background impedance of the well with culture medium alone. Cell indices (CI) were normalized to the latest time point before treatment of each groups $\left(\mathrm{CI}_{\mathrm{n}} / \mathrm{CI}_{\text {before treatment }}\right)$.

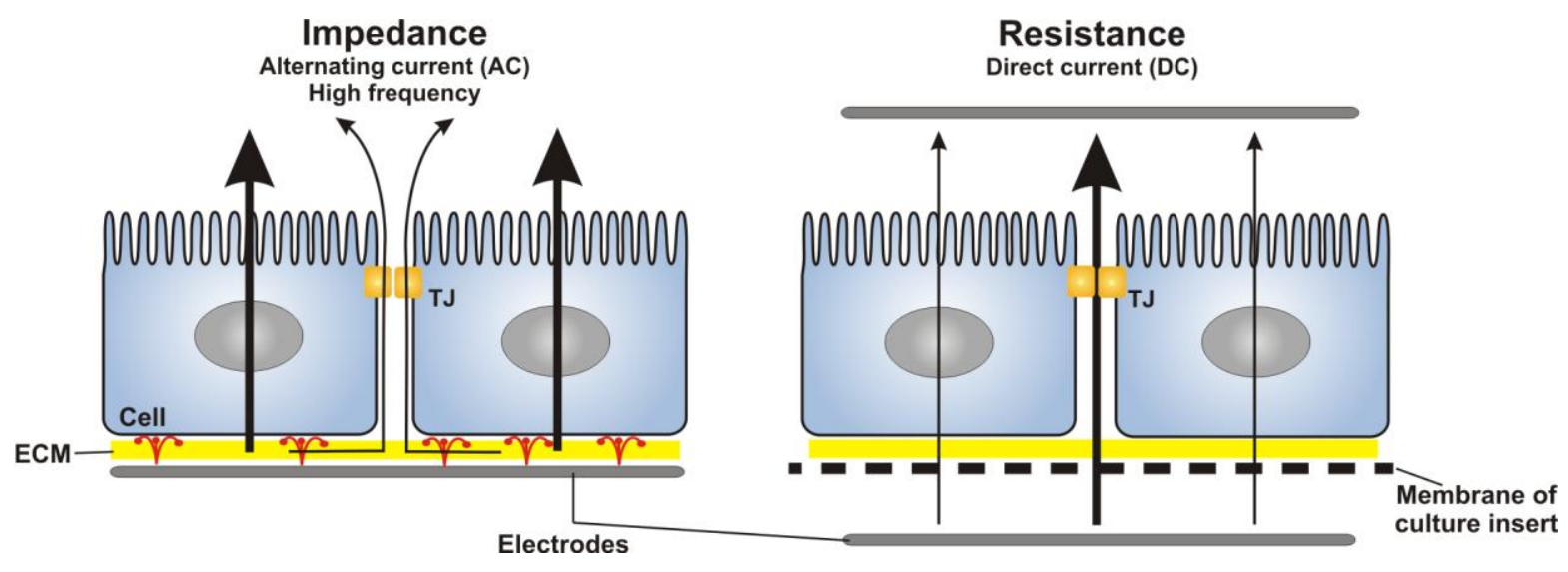

Figure 8. Cellular pathways of ion currents in case of impedance and resistance. Thick arrows show the main route of the ions. Abbreviation: ECM, extracellular matrix; TJ, tight junction 


\subsection{Measurement of electrical resistance of cell layers}

Transepithelial electrical resistance (TEER), was measured by an EVOM resistance meter using STX-2 electrodes (World Precision Instruments Inc., Sarasota, FL, USA) and expressed relative to the surface area $\left(\Omega \times \mathrm{cm}^{2}\right)$. TEER represents the paracellular permeability of cell layers for ions (Fig. 8). The TEER of Caco-2 monolayers was $800 \pm 138$ $\Omega \times \mathrm{cm}^{2}$ (mean $\left.\pm \mathrm{SD} ; \mathrm{n}=158\right)$ after 3 weeks of culture. Resistance measurements were carried out before and after permeability studies to investigate the effect of surfactants on ion flux through cellular junctions.

\subsection{Permeability study}

The flux of the drugs caffeine, antipyrine, atenolol, vinblastine and fluorescent dyes fluorescein and rhodamine 123 across epithelial cell layers was determined in apical to basal (AB) direction (Fig. 9). The flux of vinblastine, fluorescein and rhodamine 123 was also measured in basal to apical (BA) direction (Fig. 9). Caco-2 cells were seeded onto Transwell filter inserts and the resistance of the cell layers was checked twice a week. After 21 days when the resistance was high and stable, the inserts were transferred to 12-well plates containing $1.5 \mathrm{ml}$ Ringer-Hepes solution in the basolateral compartments. In apical chambers culture medium was replaced by $500 \mu$ Ringer-Hepes containing drugs or marker molecules with or without absorption enhancers. Drugs and rhodamine 123 were used at the concentration of $10 \mu \mathrm{M}$, fluorescein was administered at $10 \mu \mathrm{g} / \mathrm{ml}$ concentration. Absorption enhancers were applied in the apical compartment in the following concentrations: Tween 80 and Cremophor RH40 at 30, 60, 100, $1000 \mu \mathrm{g} / \mathrm{ml}, \mathrm{P}-1695$ and M-1695 at 30, $60 \mu \mathrm{g} / \mathrm{ml}$, and D-1216 at 30,60, $100 \mu \mathrm{g} / \mathrm{ml}$. The plates were kept in a $\mathrm{CO}_{2}$ incubator on a rocking platform (100 rpm) for 1 hour in case of atenolol, caffeine, antipyrine and rhodamine 123. For vinblastine and fluorescein 2-hour permeability test was performed, and samples were taken from the acceptor phase at both 1 and 2 hour time points. After the incubation samples from the upper and lower compartments were collected and the concentrations of fluorescein and rhodamine 123 were determined by a fluorescent microplate reader (Fluostar Optima) while drug concentrations were measured by HPLC, as detailed below. The apparent permeability coefficients $\left(\mathrm{P}_{\mathrm{app}}\right)$ in $\mathrm{AB}$ and $\mathrm{BA}$ directions, and the clearance of the molecules were calculated (Appendix, Pub. III, Supporting Information Eq. 3-7). 


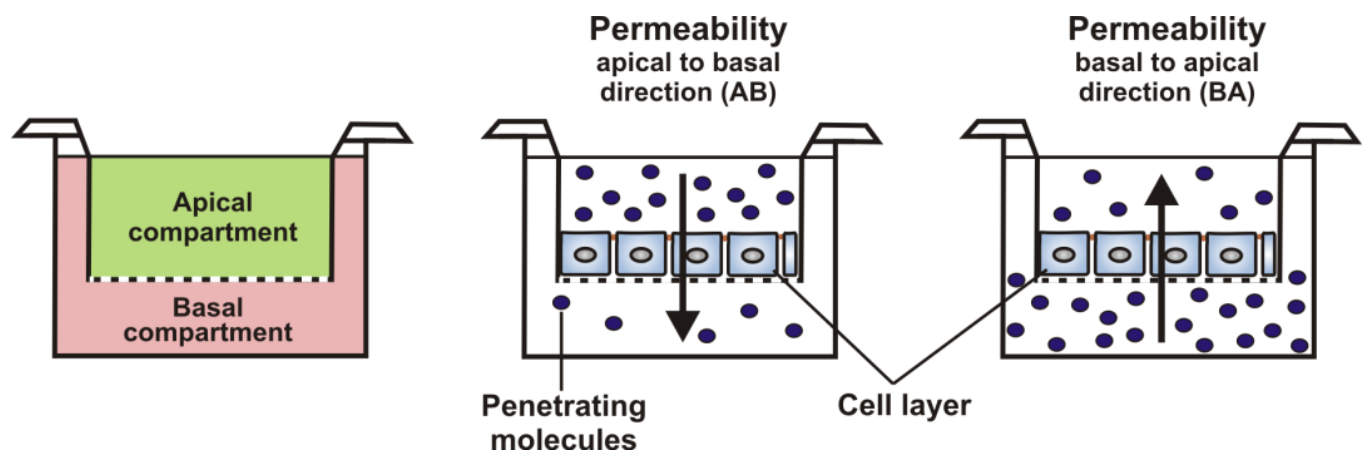

Figure 9. Schematic images about permeability study in both $A B$ and $B A$ directions. Abbreviation: $A B$, apical to basal direction; BA, basal to apical direction.

\subsection{HPLC analytical procedures}

Analytical measurements were performed on a Merck-Hitachi LaChrom HPLC system equipped with UV and fluorescence detector (Merck, Darmstadt, Germany). Antipyrine and vinblastine were determined by using Purospher C18e $125 \mathrm{~mm}$ x $3 \mathrm{~mm}(5 \mu \mathrm{m})$ column (Merck, Darmstadt, Germany) operated at $0.5 \mathrm{ml} / \mathrm{min}$ flow rate, maintained at $40{ }^{\circ} \mathrm{C}$. Mobile phase for antipyrine consisted of $40 \%$ methanol in $0.1 \mathrm{M}$ ammonium acetate with isocratic elution. UV detection was at $250 \mathrm{~nm}$ wavelength. The calibration curve showed a good linearity within the examined concentration range of $0.1-10 \mu \mathrm{M}\left(\mathrm{r}^{2}=0.999\right)$. For vinblastine, elution was applied to a mixture of $250 \mathrm{ml}$ methanol, $200 \mathrm{ml} 25 \mathrm{nM}$ ammonium-acetate and $3 \mathrm{ml} 10 \%$ trifluoroacetic acid. Vinblastine was quantified at 275/360 nm excitation/emission wavelengths. The calibration curve was linear with an $\mathrm{r}^{2}=0.998$ in the range of $0.01-1 \mu \mathrm{M}$. Samples with higher than $1 \mu \mathrm{M}$ vinblastine concentration were 10x diluted in Ringer-Hepes solution. HPLC measurement of caffeine was performed using Purospher C18e $125 \mathrm{~mm}$ x $4 \mathrm{~mm}(5 \mu \mathrm{m})$ column (Merck, Darmstadt, Germany) operated at $0.8 \mathrm{ml} / \mathrm{min}$ flow rate, maintained at $35^{\circ} \mathrm{C}$. Mobile phase was $15 \%$ methanol in $0.1 \mathrm{M}$ ammonium acetate. UV detection was at $275 \mathrm{~nm}$. The $\mathrm{r}^{2}$ of the calibration curve was 0.999 in the concentration range of 0.1-10 $\mu \mathrm{M}$. Samples with atenolol were injected onto a Gemini C18e $150 \mathrm{~mm}$ x $3 \mathrm{~mm}$ (5 $\mu \mathrm{m}$ ) column (Phenomenex Inc., Aschaffenburg, Germany) operated at $35^{\circ} \mathrm{C}$ and at an eluent flow rate of $0.5 \mathrm{ml} / \mathrm{min}$. Elution was applied to a mixture of $300 \mathrm{ml}$ methanol, $400 \mathrm{ml} 0.1 \mathrm{M}$ ammoniumacetate, $20 \mathrm{ml} 10 \%$ ammonium hydroxide and $2 \mathrm{ml} 0.1 \mathrm{M} \mathrm{Na} 2$ EDTA. Atenolol was quantified at 230/300 $\mathrm{nm}$ excitation/emission wavelengths. The calibration curve was linear with an $\mathrm{r}^{2}=0.999$ in the range of $0.01-1 \mu \mathrm{M}$. Samples with higher than $1 \mu \mathrm{M}$ atenolol concentration were diluted 10x in Ringer-Hepes solution. 


\subsection{Measurement of plasma membrane fluidity in Caco-2 cells}

Caco-2 cells were collected by trypsinization, washed twice and resuspended in PBS. The density of cells was set by absorbance measurement at $360 \mathrm{~nm}$ to $\mathrm{OD}_{360}=0.1$ (Hewlett Packard 8452A Diode Array Spectrophotometer). Cells were labeled with $0.2 \mu \mathrm{M}$ TMADPH (1-(4-trimethylammoniumphenyl)-6-phenyl-1,3,5-hexatriene; Molecular Probes, Life Technologies) for 5 minutes. Fluorescence anisotropy was measured on a T-format fluorescence spectrometer (Quanta Master QM-1, Photon Technology International, Princeton, NJ, USA) (Török et al., 1997; Balogh et al., 2011). Excitation and emission wavelengths were 360 and $430 \mathrm{~nm}$, respectively (5-nm slits). Cells were kept at $37^{\circ} \mathrm{C}$ under stirring conditions. Anisotropy data were acquired in every second. After 5 minutes the lowest concentrations of treatment solutions were added rapidly to the cell suspension and every 3 minutes the treatment concentration was increased during anisotropy measurements. Control cells received only vehicle. A strong membrane fluidizer, benzyl alcohol (30 mM); (Merck, Darmstadt, Germany) was used as a positive control in the experiments. The following treatment concentrations were applied: $1,10,30,60,100 \mu \mathrm{g} / \mathrm{ml}$ for sucrose ester, and $1,10,100,1000 \mu \mathrm{g} / \mathrm{ml}$ for Tween 80 and Cremophor RH40. The average of 50 anisotropy measurements in the last 1 minute of each treatment concentration was calculated and compared to the anisotropy of the vehicle-treated cells at the same time point.

\subsection{Measurement of efflux pump activity}

The activity of efflux pumps was determined by cellular accumulation of rhodamine 123 and calcein AM (Life Technologies, Carlsbad, CA, USA) in Caco-2 epithelial cells grown in 24-well plates for 2 days (seeding density: $10^{5}$ cells/well). Cells were pre-incubated with Ringer-Hepes buffer for 20 minutes. Treatments with surfactants, P$1695(30 \mu \mathrm{g} / \mathrm{ml})$, M-1695 (60 $\mu \mathrm{g} / \mathrm{ml})$, D-1216 (100 $\mu \mathrm{g} / \mathrm{ml})$, Tween $80 \quad(1000 \mu \mathrm{g} / \mathrm{ml})$, Cremophor RH40 $(1000 \mu \mathrm{g} / \mathrm{ml})$ or efflux pump inhibitors, verapamil $(100 \mu \mathrm{M})$ and cyclosporin $\mathrm{A}(10 \mu \mathrm{M})$ were performed in the presence of rhodamine 123 for 1 hour. Following incubations cells were washed three times with ice cold PBS and lysed with $0.1 \mathrm{M} \mathrm{NaOH}$. Rhodamine 123 concentration was determined by a fluorescent microplate reader (excitation wavelength: $485 \mathrm{~nm}$, emission wavelength: $520 \mathrm{~nm}$; Fluostar Optima).

The calcein AM assay can be used for the measurement of the activity of efflux transporters P-gp, MRP-1 and MRP-2 (Juvale et al, 2012; Hanke et al, 2010). The cellular transport of the non-fluorescent calcein AM is inhibited by efflux transporters, therefore only limited amount gets into the cells where intracellular esterases convert the dye to a fluorescent 
metabolite. For calcein AM assay Caco-2 cells were seeded on 96-well plate (cell density: $7 \times 10^{4}$ cells/well) and grew for 24 hours. Before experiments cells were pre-incubated with Ringer-Hepes for 20 minutes. Treatments with surfactants or efflux pump inhibitors were performed in the presence of $1.25 \mu \mathrm{M}$ calcein AM. Fluorescence was immediately measured by a microplate reader at 5 minutes interval for 1 hour (excitation wavelength: $485 \mathrm{~nm}$; emission wavelength: $520 \mathrm{~nm}$ ). The fluorescence intensity was calculated as percentage of the control group.

To estimate the effect of sucrose esters on P-glycoprotein functionality, calcein accumulation was measured in the presence of the test substrates in MES-SA and MESSA/Dx5 cells (Karászi et al., 2001; Türk et al., 2009). Cells $\left(2 \times 10^{5}\right.$ cells/100 $\left.\mu 1\right)$ were preincubated with verapamil $(100 \mu \mathrm{M})$, P-1695 $(30 \mu \mathrm{g} / \mathrm{ml}), \mathrm{M}-1695(30 \mu \mathrm{g} / \mathrm{ml})$, D-1216 $(100 \mu \mathrm{g} / \mathrm{ml})$, Tween $80(100 \mu \mathrm{g} / \mathrm{ml})$, Cremophor RH40 $(1000 \mu \mathrm{g} / \mathrm{ml})$ or with solvent DMSO (less than $0.1 \%$ ) for $5 \mathrm{~min}$ at $37^{\circ} \mathrm{C}$. M-1695 and Tween 80 were applied in lower concentrations due to different sensitivity of sarcoma cells as compared to Caco-2 cells. Thereafter $0.25 \mu \mathrm{M}$ calcein $\mathrm{AM}$ was added and the cells were incubated for $10 \mathrm{~min}$ at $37^{\circ} \mathrm{C}$. Cells were gated based on TO-PRO3 positivity (Life Technologies, Carlsbad, CA, USA). Samples were measured by a FACSCalibur ${ }^{\mathrm{TM}}$ flow cytometer (BD Biosciences, San Jose, CA, USA).

\subsection{Statistical analysis}

All data presented are means \pm SD. Values were compared using analysis of variance (ANOVA) followed by Dunnett's test (GraphPad Prism 5.0, GraphPad Software Inc., San Diego, CA, USA). In case of fluorescein, vinblastine, and rhodamine 123 permeability and TMA-DPH anisotropy measurements two-way ANOVA followed by Bonferroni posttest was applied. Changes were considered statistically significant at $P<0.05$. All experiments were repeated at least two times, the number of parallel samples varied between 4 and 12 . 


\section{RESULTS}

\subsection{Effects of non-ionic surfactants on viability of intestinal epithelial and vascular endothelial cells}

The toxic effects of Cremophor RH40 and EL were investigated and compared by different methods and in wide concentration range on Caco-2 and hCMEC/D3 cell lines and pimary rat brain endothelial cells. Colorimetric assays were carried out after treatments with Cremophors for 1 and 24 hours (Fig. 10). Epithelial cells remained viable and no membrane damage was observed after 1 hour treatment with surfactants (Fig. 10a). Cremophors at 10 and $50 \mathrm{mg} / \mathrm{ml}$ concentrations elevated MTT dye conversion. After 24 hour treatment Cremophor RH40 at $50 \mathrm{mg} / \mathrm{ml}$ concentration reduced the viability of epithelial cells measured by MTT assay and Cremophor EL caused total cell death at the same concentration (Fig. 10b), indicating higher toxicity. The LDH enzyme leakage was increased after treatment by Cremophors $(5-50 \mathrm{mg} / \mathrm{ml})$ at 24-hour.
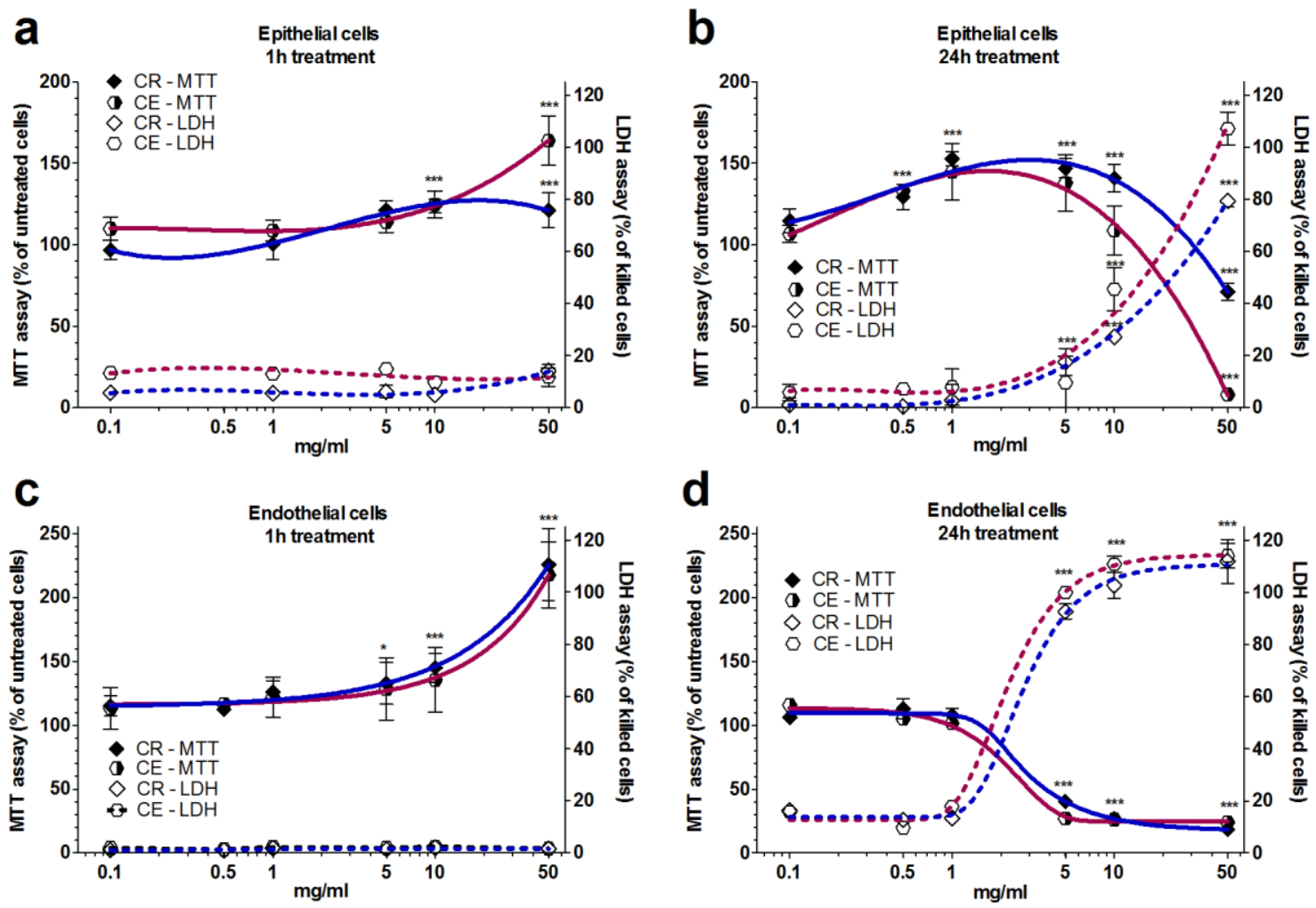

Figure 10. Effects of Cremophor RH40 and EL (0.1-50 mg/ml) on human Caco-2 epithelial (a, b) and hCMEC/D3 endothelial cells $(s, d)$ measured by MTT dye conversion and LDH release methods. The MTT values were compared to non-treated group which was defined as $100 \%$ viable. For LDH measurement the Triton-X 100 treated group was considered as $100 \%$ dead. Data are presented as mean \pm S.D., $n=5$; statistical analysis: ANOVA followed by Dunnett test; ${ }^{*} P<0.05$, ${ }^{* *} P<0.001$, all treatment groups were compared to control. CR, Cremophor RH40; CE, Cremophor EL. 
Cremophor treatments for 1 hour did not decrease the viability of D3 endothelial cells measured by MTT and LDH assays (Fig. 10c-d). Surfactants (5-50 mg/ml, 1 hour) significantly increased MTT dye conversion of D3 endothelial cells similarly to Caco-2 cells (Fig. 10c). Both types of Cremophors $(5-50 \mathrm{mg} / \mathrm{ml})$ induced cellular damage in concentration dependent manner in endothelial cells after 24-hour treatments (Fig. 10d). MTT and LDH colorimetric assays confirmed on epithelial cells that Cremophor RH40 is less toxic than Cremophor EL. Vascular endothelial cells were more sensitive to treatments with surfactants than intestinal epithelial cells. Cremophors killed endothelial cells at $5 \mathrm{mg} / \mathrm{ml}$ and higher concentrations, while similar effect was observed at $50 \mathrm{mg} / \mathrm{ml}$ concentration in epithelial cells.
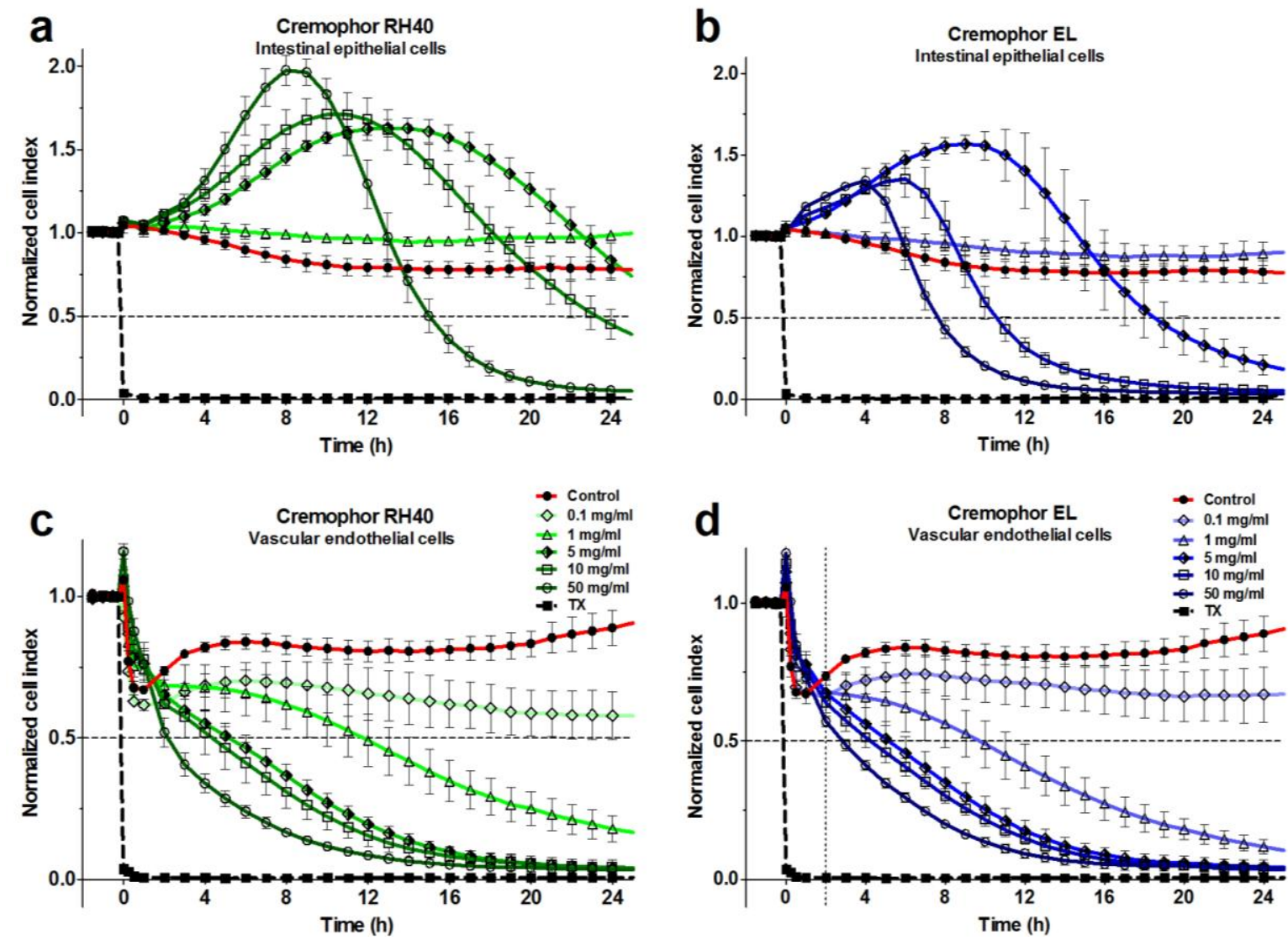

Figure 11. Effects of Cremophor RH40 and EL $(0.1-50 \mathrm{mg} / \mathrm{ml})$ on human Caco-2 intestinal epithelial $(\mathrm{a}, \mathrm{b})$ and hCMEC/D3 endothelial (c, d) cells measured by real-time cell microelectronic sensing method. Cell index is expressed as an arbitrary unit and calculated from impedance measurements between cells and sensors. Data are presented as mean \pm S.D., $n=4$. TX, Triton $X-100$ at $10 \mathrm{mg} / \mathrm{ml}$ concentration.

The toxicokinetic effects of Cremophors were monitored by real-time impedance measurement on epithelial and endothelial cells. Cell damage was specified as normalized cell index (CI), below the value of 0.5. After a transient increase, Cremophors time- and concentration-dependently decreased cell index values (Fig. 11). Cremophor RH40 at 1 and $5 \mathrm{mg} / \mathrm{ml}$ concentrations did not induce cellular toxicity (Fig. 11a), while only $1 \mathrm{mg} / \mathrm{ml}$ 
concentration of Cremophor EL was non-toxic for epithelial cells after 24 hours (Fig. 11b). Ten and $50 \mathrm{mg} / \mathrm{ml}$ concentrations of Cremophor RH40 increased the impedance in the first 8-10 hours, than a gradual decrease could be observed and cell toxicity was measured after 23 or 15 hours, respectively, (Fig. 11a). The effect of Cremophor EL was similar to RH40 on epithelial cells, but the impedance drop and cell death were faster (Fig. 11b). Cremophors changed the cell index in concentration and time dependent manner on hCMEC/D3 endothelial cells (Fig. 11c-d). No decrease compared to control was observer at 1 hour treatment, but after 2 hours the surfactants significantly reduced the CI of endothelial cells. The $0.1 \mathrm{mg} / \mathrm{ml}$ concentrations lowered the impedance without toxic effects, but higher concentrations damaged the endothelial cells.

\section{Intestinal epithelial cells}

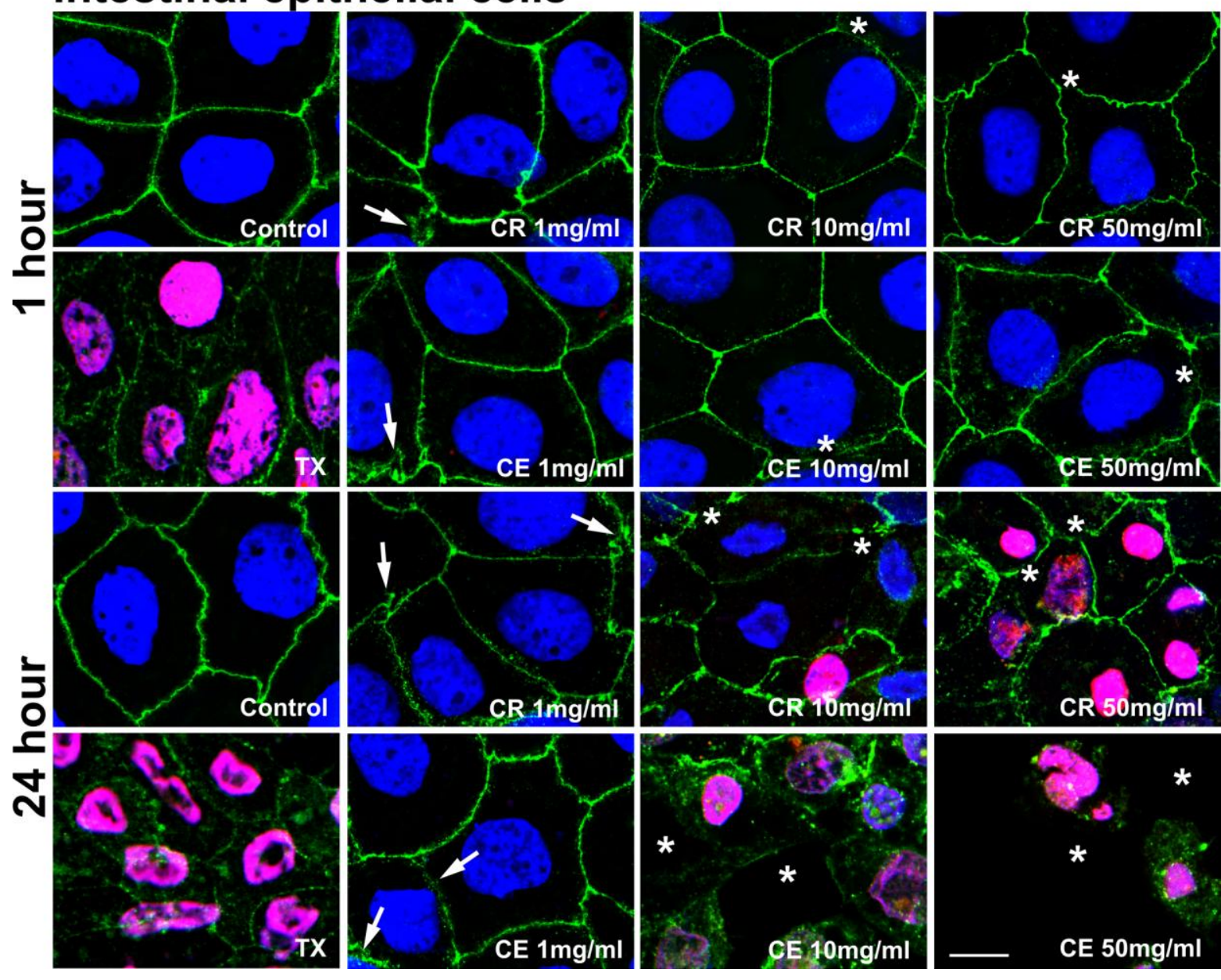

Figure 12. Fluorescent staining of cell nuclei and tight junction membrane protein claudin-4 in Caco-2 epithelial cells after 1 and 24-hour treatments with Cremophors. Blue color: cell nuclei of living cells; red color: dead cells; green color: claudin immunostaining. Asterisk: holes formed between cells, fragmentation or loss of junctional immunostaining; arrows: changes in claudin immunostaining of cell membranes; CR, Cremophor RH40; $\mathrm{CE}$, Cremophor EL; TX, Triton X-100. Bar $=10 \mu \mathrm{m}$. 
The toxicity of Cremophors was also examined by fluorescent cell nuclei staining of epithelial and endothelial cells after 1-h and 24-h treatments. In Caco-2 epithelial cells no difference in nucleus staining was noticed after a 1-hour treatment with Cremophors (Fig. 12). Changes in claudin-4 staining could be detected already at 1hour treatment, disappearance or weak immunostaining at cell junctions, irregular membrane or cytoplasmic staining patterns were observed (Fig. 12). Incubation for 24 hours with Cremophors at $1 \mathrm{mg} / \mathrm{ml}$ concentration did not kill epithelial cells, but claudin-4 immunostaining became irregular and its membrane localization became disturbed. Both epithelial viability and monolayer integrity were seriously impaired at $10-50 \mathrm{mg} / \mathrm{ml}$ concentrations at 24 hour treatment. Cremophor EL enhanced cell detachment.

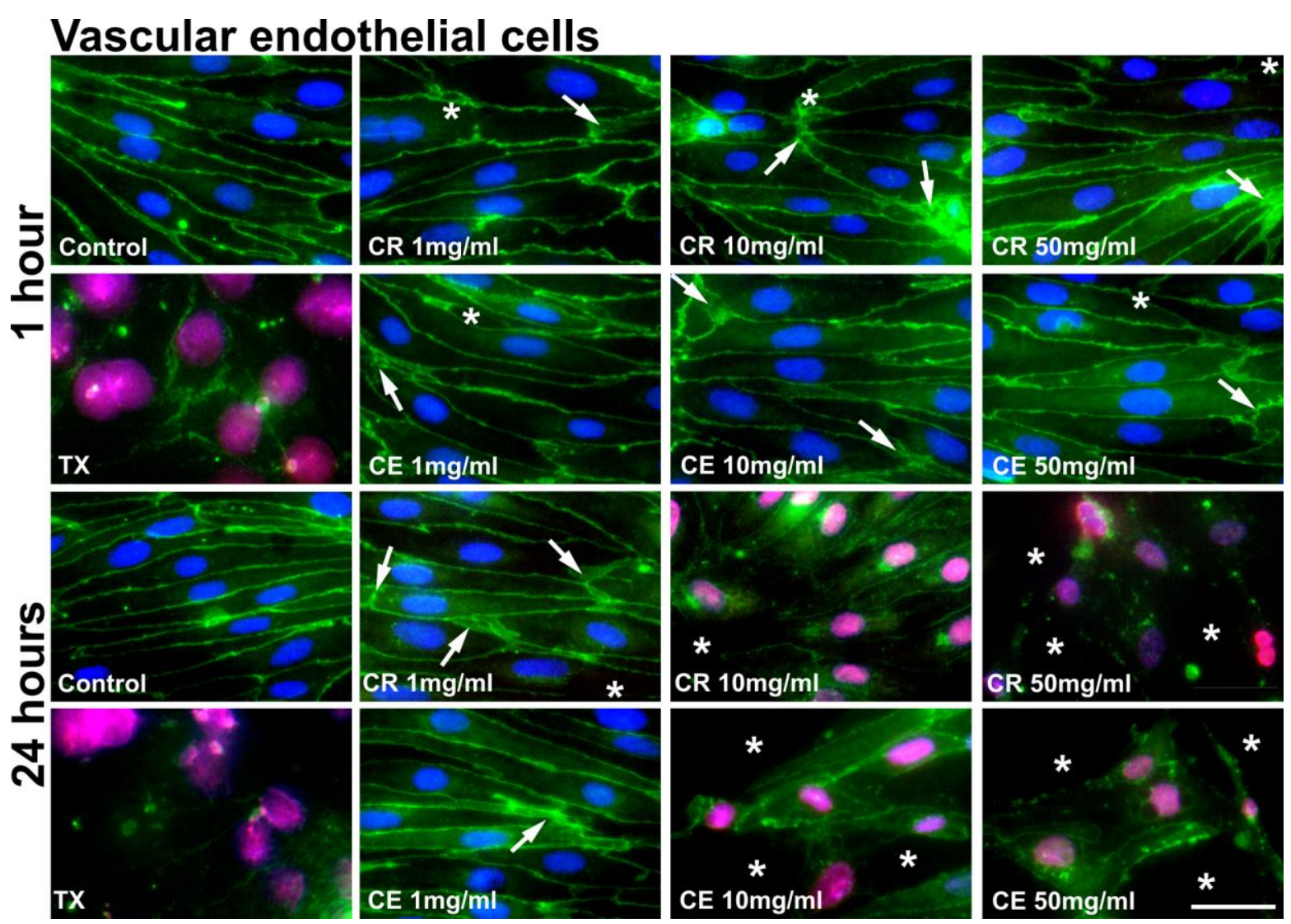

Figure 13. Fluorescent staining of cell nuclei and tight junction membrane protein claudin-5 in primary rat brain vascular endothelial cells after 1 and 24-hour treatment with Cremophors. Blue color: cell nuclei of living cells; red color: dead cells; green color: claudin immunostaining. Asterisk: holes formed between cells, fragmentation or loss of junctional immunostaining; arrows: changes in claudin immunostaining of cell membranes; CR, Cremophor RH40; CE, Cremophor EL; TX, Triton X-100. Bar=30 $\mu \mathrm{m}$.

Short treatment with surfactants $(1-50 \mathrm{mg} / \mathrm{ml})$ did not result in endothelial cell death, as demonstrated by the blue cell nuclei (Fig. 13). Treatment with Cremophors 
from $10 \mathrm{mg} / \mathrm{ml}$ for 24 hours or Triton-X 100 led to red staining of cell nuclei indicating membrane damage and toxicity (Fig. 13). Immunostaining for claudin-5 endothelial TJ protein was changed by all investigated concentrations of Cremophors at 1-h incubation. In contrast to control cells where a typical continuous belt-like staining was seen holes appeared between cells indicating barrier damage. Uneven pericellular claudin-5 staining with thickening and zipper-like pattern was also observed (Fig. 13). After 24-hour disappearance and disorganization of the junctional staining was observed. Cremophors at the highest concentrations of 10 and $50 \mathrm{mg} / \mathrm{ml}$ induced cell detachment and cell death.
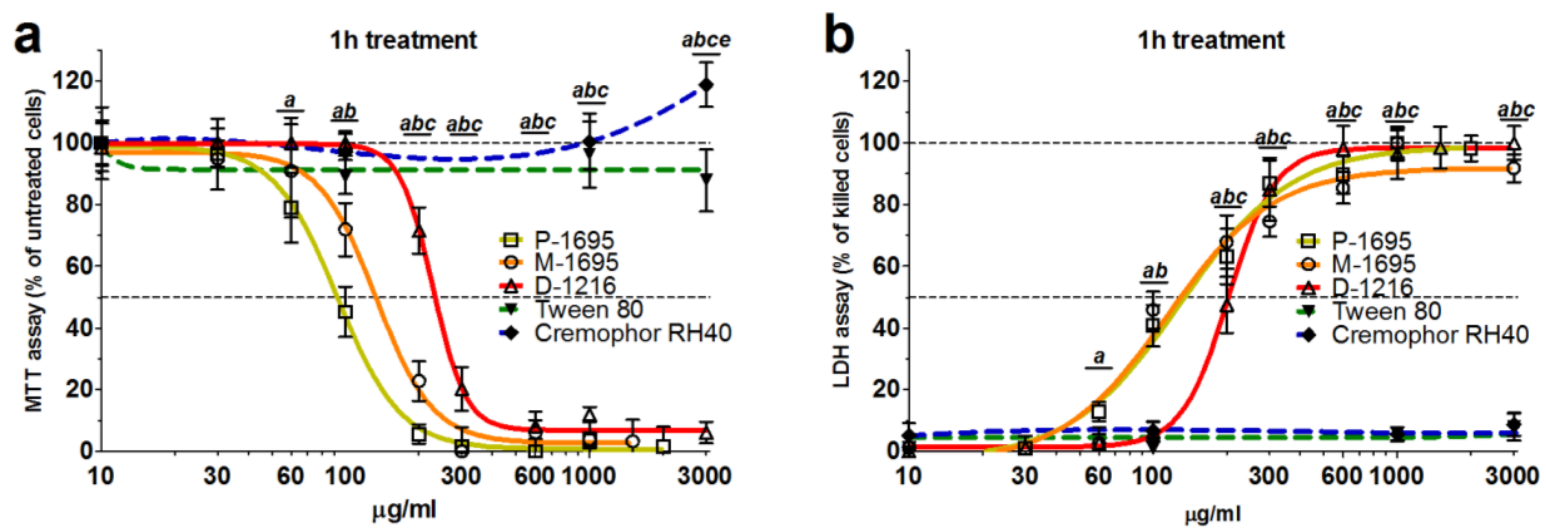

Figure 14. Toxicity of P-1695, M-1695, D-1216 sucrose fatty acid esters $(10-3000 \mu \mathrm{g} / \mathrm{ml})$ and Tween 80 , Cremophor $\mathrm{RH} 40$ reference absorption enhancers $(10-3000 \mu \mathrm{g} / \mathrm{ml})$ on human Caco-2 intestinal epithelial cells measured by (a) MTT dye conversion and (b) LDH release methods. MTT values were compared to non-treated group (100\% viability). For LDH measurement values were compared to the Triton-X 100 treated group (100\% toxicity). Data are presented as mean \pm S.D., $n=6$; statistical analysis: ANOVA followed by Dunnett test; statistically significant differences $(P<0.05)$ were detected in the control group compared to the values measured in a: P-1695 group; b: M-1695 group; c: D-1216 group; e: Cremophor RH40 group.

The effect of sucrose esters and reference non-ionic surfactants, Tween 80 and Cremophor RH40 on cell viability was also investigated and compared by colorimetric assays on Caco-2 intestinal epithelial cells. Treatment of Caco-2 cells with sucrose esters time- and concentration-dependently decreased the MTT dye conversion indicating reduced cell viability (Fig. 14 and Table 4). P-1695 palmitate and M-1695 myristate esters significantly reduced metabolic activity of Caco-2 cells at concentrations higher than 30 or $60 \mu \mathrm{g} / \mathrm{ml}$, respectively, and caused cell death above $200 \mu \mathrm{g} / \mathrm{ml}$ (Fig. 14a). D1216 laurate ester was the least toxic among the investigated sucrose esters, the $100 \mu \mathrm{g} / \mathrm{ml}$ concentration did not decrease epithelial cell viability, but 200 to $600 \mu \mathrm{g} / \mathrm{ml}$ concentrations reduced MTT conversion in epithelial cells after 1 hour. The reference 
surfactants showed lower toxicity on epithelial cells. Tween 80 or Cremophor RH40 at $3,000 \mu \mathrm{g} / \mathrm{ml}$ concentration did not reduce cell viability of epithelial cells for 1 hour (Fig. 14a). The highest concentration of Cremophor RH40 increased MTT dye conversion in Caco-2 cells. Similar viability results to MTT test were obtained by measurements of LDH enzyme release indicating plasma membrane damage. The nontoxic concentrations for all sucrose esters were the same with both cell viability methods. Cell death was observed after 1-hour treatment with sucrose esters $(>300 \mu \mathrm{g} / \mathrm{ml})$, but Tween 80 or Cremophor RH40 did not increase the enzyme release at any tested concentrations (Fig. 14b).

The concentrations of surfactants causing $50 \%$ or complete cell death (TC 50 and TC 100) at 24 hours were lower than for the 1-hour treatments (Table 4). The non-toxic concentrations of P-1695, M-1695 and D-1216 were about 20, 20 and $100 \mu \mathrm{g} / \mathrm{ml}$, respectively, by both assays. The toxic concentrations of reference absorption enhancers were more than one order of magnitude higher than that of sucrose esters. The TC 0 values for Tween 80 were calculated as $473 \mu \mathrm{g} / \mathrm{ml}$ (MTT test) and $1068 \mu \mathrm{g} / \mathrm{ml}$ (LDH assay). The non-toxic concentrations of Cremophor RH40 on Caco-2 cells for $24 \mathrm{~h}$ were $30,000 \mu \mathrm{g} / \mathrm{ml}$ and $2067 \mu \mathrm{g} / \mathrm{ml}$ determined by MTT test and LDH assay, respectively (Table 4).

\begin{tabular}{|c|c|c|c|c|c|c|}
\hline Absorption enhancers & \multicolumn{3}{|c|}{ MTT dye conversion } & \multicolumn{3}{|c|}{ LDH enzyme release } \\
\hline & $\begin{array}{c}\text { TC 0 } \\
(\boldsymbol{\mu g} / \mathbf{m l})\end{array}$ & $\begin{array}{c}\text { TC 50 } \\
(\boldsymbol{\mu g} / \mathbf{m l})\end{array}$ & $\begin{array}{c}\text { TC 100 } \\
(\boldsymbol{\mu g} / \mathbf{m l})\end{array}$ & $\begin{array}{c}\text { TC 0 } \\
(\boldsymbol{\mu g} / \mathbf{m l})\end{array}$ & $\begin{array}{c}\text { TC 50 } \\
(\boldsymbol{\mu g} / \mathbf{m l})\end{array}$ & $\begin{array}{c}\text { TC 100 } \\
(\boldsymbol{\mu g} / \mathbf{m l})\end{array}$ \\
\hline P-1695 & 19 & 49 & 128 & 20 & 72 & 260 \\
\hline M-1695 & 18 & 62 & 211 & 20 & 61 & 189 \\
\hline D-1216 & 99 & 189 & 360 & 92 & 162 & 283 \\
\hline Tween 80 & 473 & 1073 & 2432 & 1068 & 1229 & 1621 \\
\hline Cremophor RH40 & 30900 & 33884 & n.a. & 2067 & 11810 & 44668 \\
\hline
\end{tabular}

Table 4. Toxicity of P-1695, M-1695, D-1216 sucrose fatty acid esters and Tween 80 , Cremophor RH40 reference absorption enhancers on human Caco-2 intestinal epithelial cells was measured by MTT dye conversion and LDH release methods after 24 hours of incubations. The MTT values were compared to nontreated group (100\% viability). For LDH measurement groups were compared to the Triton-X 100 treated group (100\% toxicity). TC 0 , non toxic concentration; TC 50, caused $50 \%$ toxicity, TC 100, $100 \%$ cell death; n.a., not applicable.

Based on the results of the toxicity tests for 1 hour, the following concentrations were considered as safe for treatments and applied in further experiments on Caco-2 epithelial cells: P-1695 $30 \mu \mathrm{g} / \mathrm{ml}, \mathrm{M}-169560 \mu \mathrm{g} / \mathrm{ml}, \mathrm{D}-1216100 \mu \mathrm{g} / \mathrm{ml}$. For reference surfactants, Tween 80 and Cremophor RH40 the non-toxic and clinically relevant $1000 \mu \mathrm{g} / \mathrm{ml}$ 
concentration was selected for further treatments (Kiss et al., 2013; Weis et al., 1994; Mercke Odeberg et al., 2003).

\subsection{Effects of sucrose esters and reference surfactants on the electrical resistance and impedance of epithelial cell layers}

Non-toxic concentrations of sucrose esters but not of reference surfactants increased the ionic permeability across Caco-2 monolayers monitored by impedance and TEER measurements (Fig. 15). Sucrose esters reduced the impedance of epithelial cell layers measured by RTCA SP (Fig. 15a). The impedance decreased rapidly from the baseline of $125 \Omega$ to $90 \Omega$ within 30 minutes by $\mathrm{P}-1695(30 \mu \mathrm{g} / \mathrm{ml})$ and $\mathrm{D}-1216$ $(100 \mu \mathrm{g} / \mathrm{ml})$ treatments. M-1695 $(60 \mu \mathrm{g} / \mathrm{ml})$ also significantly reduced the impedance of Caco-2 layers. Slight decrease but no significant change was caused by Tween 80 or Cremophor RH40. In accordance with the impedance measurements P-1695, M-1695 and D-1216 reduced the resistance of the cell layers to $25 \%, 55 \%$ and $62 \%$ as compared to control at 1-hour treatment, but no change was observed for reference surfactants (Fig. 15b).
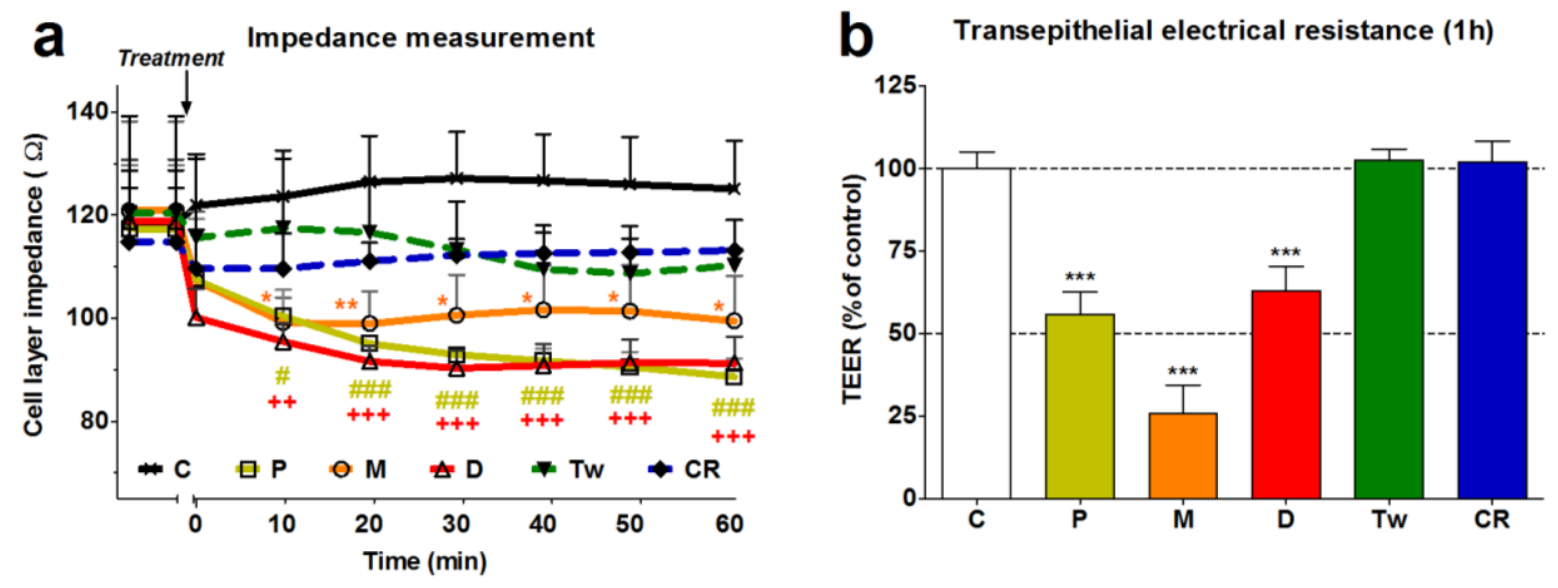

Figure 15. Effects of P-1695 (30 $\mu \mathrm{g} / \mathrm{ml}), \mathrm{M}-1695(60 \mu \mathrm{g} / \mathrm{ml}), \mathrm{D}-1216(100 \mu \mathrm{g} / \mathrm{ml})$ sucrose fatty acid esters and Tween $80(1000 \mu \mathrm{g} / \mathrm{ml})$, Cremophor RH40 $(1000 \mu \mathrm{g} / \mathrm{ml})$ reference absorption enhancers on the impedance (a), and transepithelial electrical resistance (b) on Caco-2 epithelial cell layers. Data are presented as mean \pm S.D., $\mathrm{n}=4$; statistical analysis: ANOVA followed by Dunnett test. Impedance measurement (a): statistically significant differences were detected after treatment with $\mathrm{P}-1695(\# P<0.05$, \#\#\# $P<0.001) ; \mathrm{M}-1695\left({ }^{*} P<0.05\right.$, $\left.{ }^{* *} P<0.01\right)$; D-1216 (+ $\left.P<0.05,+++P<0.001\right)$ compared to the control group. TEER measurements (b): statistically significant differences were detected in sucrose ester treated groups ( ${ }^{\star * *} P<0.001$ ) compared to control. Abbreviations: C, control; P, P-1695; M, M-1695; D, D1216; Tw, Tween 80; CR, Cremophor RH40. 


\subsection{Effects of surfactants on epithelial cell layer permeability for drugs and fluorescein}

The permeability of hydrophilic atenolol was low $\left(0.17 \times 10^{-6} \mathrm{~cm} / \mathrm{s}\right)$ across Caco-2 cells and all surfactants significantly enhanced the penetration of atenolol across cell layers (Table 5). The $\mathrm{P}_{\text {app }}$ of passive lipophilic drugs antipyrine $\left(80.67 \times 10^{-6} \mathrm{~cm} / \mathrm{s}\right)$ and caffeine $\left(87.59 \times 10^{-6} \mathrm{~cm} / \mathrm{s}\right)$ was high and the absorption enhancers did not increase it (Table 5).

The average apparent permeability coefficient of fluorescein was also low (AB: $0.36 \times 10^{-6} \mathrm{~cm} / \mathrm{s}$; BA: $1.82 \times 10^{-6} \mathrm{~cm} / \mathrm{s}$ ), but higher in the BA direction (BA/AB ratio: 5.1) (Fig. 16a), indicating active efflux transport in accordance with literature data on MRP2 mediated efflux of fluorescein (Legen et al., 2004). Using previously selected non-toxic concentrations for each surfactant, all investigated compounds caused significant increase in fluorescein flux in $\mathrm{AB}$ direction across Caco-2 layers after 1 and 2-hour treatments (Fig. 16a and Appendix, Pub. III, Fig. S1). M-1695 myristate $(60 \mu \mathrm{g} / \mathrm{ml})$ and D-1216 laurate $(100 \mu \mathrm{g} / \mathrm{ml})$ sucrose esters highly increased the flux of fluorescein at 1 and 2-hour application (Fig. 16a). The elevation in fluorescein permeability caused by P-1695 sucrose ester $(30 \mu \mathrm{g} / \mathrm{ml})$ was smaller, but also significant (Fig. 16a). Tween $80(1000 \mu \mathrm{g} / \mathrm{ml})$ enhanced three fold the flux of fluorescein, while Cremophor RH40 at similar concentration elevated the dye permeability to $211 \%$. Only myristate sucrose ester, Tween 80, and Cremophor RH40 enhanced significantly the fluorescein penetration in the opposite direction (BA). A lag time was observed in the penetration enhancing effect of all surfactants based on clearance data of fluorescein in both directions in Caco-2 cells (Appendix, Pub. III, Fig. S1a-b).
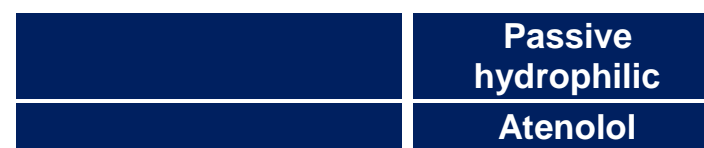

Passive lipophilic

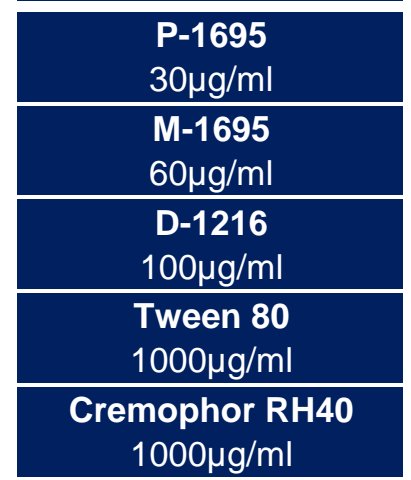

\begin{tabular}{|l|l|l|}
\hline $1.46 \pm 0.02^{* * *}$ & $1.01 \pm 0.01$ & $0.95 \pm 0.06$ \\
\hline $2.37 \pm 0.63^{* * *}$ & $0.99 \pm 0.01$ & $1.00 \pm 0.02$ \\
\hline $1.58 \pm 0.08^{* * *}$ & $0.98 \pm 0.03$ & $0.99 \pm 0.03$ \\
\hline $2.11 \pm 0.02^{* * *}$ & $1.06 \pm 0.02$ & $1.00 \pm 0.02$ \\
\hline $1.20 \pm 0.15^{* * *}$ & $1.00 \pm 0.03$ & $0.98 \pm 0.01$ \\
\hline
\end{tabular}

Table 5. Fold changes in the apparent permeability coefficients of atenolol, caffeine and antipyrine measured on confluent human Caco-2 intestinal epithelial cell layers after 1-hour treatment with P-1695, M-1695, D-1216 sucrose fatty acid esters and Tween 80 , Cremophor $\mathrm{RH} 40$ reference absorption enhancers. Data are presented as mean $\pm \mathrm{S}$.D., $\mathrm{n}=3$; statistical analysis: ANOVA followed by Dunnett test; ${ }^{* *} P<0.001$, all concentrations were compared to control. 
Sucrose esters and reference absorption enhancers were also tested at 30, 60, and $100 \mu \mathrm{g} / \mathrm{ml}$ concentrrations for 1 hour (Fig. 16b-d). The effect of sucrose esters on fluorescein permeability was concentration dependent (Fig. 16b-d). At $30 \mu \mathrm{g} / \mathrm{ml}$ concentration P-1695 and M-1695 sucrose esters, but not the other surfactants (Fig. 16b), at $60 \mu \mathrm{g} / \mathrm{ml}$ concentration both M-1695 myristate and D-1216 laurate sucrose esters increased the permeability of the dye (Fig. 16c). D-1216 $(100 \mu \mathrm{g} / \mathrm{ml})$ raised the fluorescein flux two fold compared to control (Fig. 16d). In contrast to sucrose esters reference absorption enhancers in the concentration range of $30-100 \mu \mathrm{g} / \mathrm{ml}$ did not increase the permeability of fluorescein (Fig. 16b-d).

a

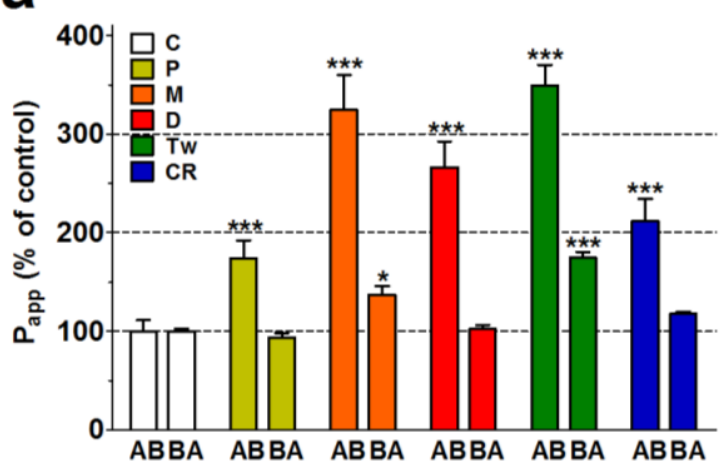

C

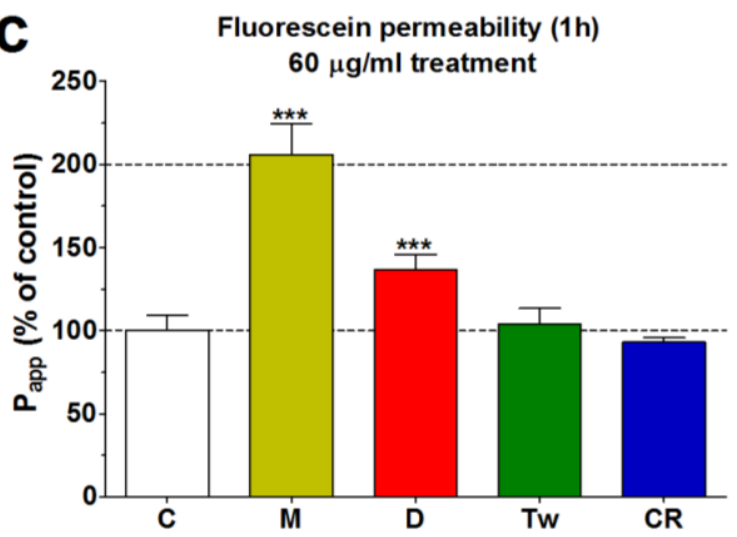

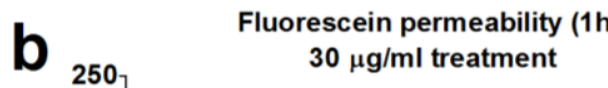

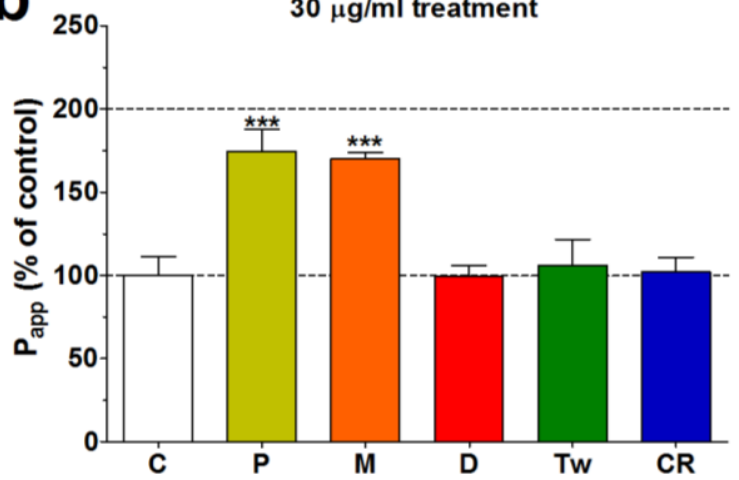

d

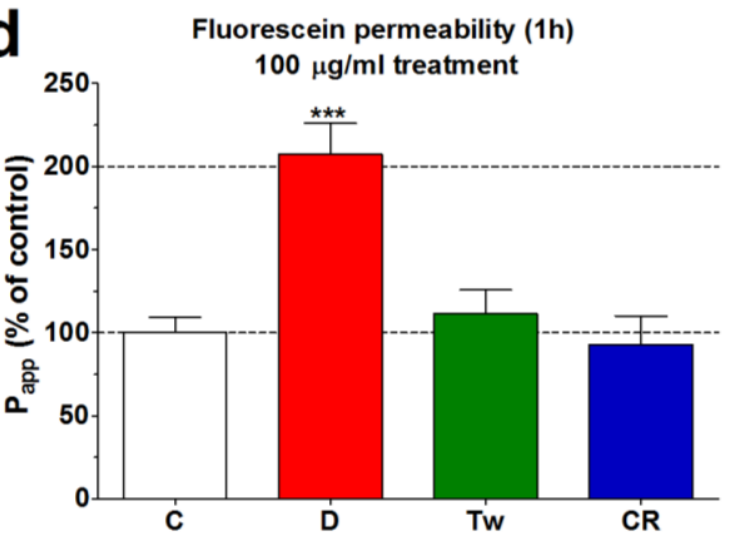

Figure 16. The effect of sucrose esters and reference absorption enhancers on the apparent permeability coefficients of fluorescein on confluent Caco-2 cell layers applied in different (a) and same (b-d) concentrations. Treatment concentrations: (a) P-1695 (30 $\mu \mathrm{g} / \mathrm{ml}), \mathrm{M}-1695(60 \mu \mathrm{g} / \mathrm{ml}), \mathrm{D}-1216(100 \mu \mathrm{g} / \mathrm{ml})$, Tween $80(1000 \mu \mathrm{g} / \mathrm{ml})$, Cremophor RH40 (1000 $\mu \mathrm{g} / \mathrm{ml}) ;$ (b) $30 \mu \mathrm{g} / \mathrm{ml}$; (c) $60 \mu \mathrm{g} / \mathrm{ml} ;$ (d) $100 \mu \mathrm{g} / \mathrm{ml}$. Data are presented as mean \pm S.D., $\mathrm{n}=3$; statistical analysis: two-way ANOVA followed by Bonferroni test (a) or ANOVA followed by Dunnett test (b-d); ${ }^{*} P<0.05,{ }^{* * *} P<0.001$, all groups were compared to their respective control. Abbreviations: $A B$, apical to basal direction; $B A$, basal to apical direction; $P_{a p p}$, apparent permeability coefficient; C, control; P, P-1695; M, M-1695; D, D-1216; Tw, Tween 80; CR, Cremophor RH40. 


\subsection{Effects of sucrose esters and reference surfactants on epithelial intercellular junctions}

Claudin-1 transmembrane TJ protein, ZO-1 cytoplasmic junctional linker protein, and $\beta$-catenin adherens junction protein all appeared at the cell-cell borders in a continuous, belt-like manner. Treatments with sucrose esters or reference surfactants for 1 hour did not affect the gross morphology of cells or intercellular junctions assessed by these immunostainings (Fig. 17a). No rupture of the junctions or fragmentation of the pericellular immunostaining was seen.

F-actin structure was investigated in different regions of epithelial cells (Fig. 17a). At the level of TJs the cortical actin ring was sharply delineated in the control cells mimicking tight junction protein immunostainings. Following treatments with sucrose esters and reference absorption enhancers this F-actin staining near the TJ region became wider and more blurred compared to control images. At the apical part of the cells the structure of microvilli was well shown by F-actin staining, which was preserved in all treatment groups (Appendix, Pub. III, Fig. S3) At the basal part of cells staining of Factin revealed long filaments organized in bunches (Appendix, Pub. III, Fig. S3). This filamentous organization was less observed in the treatment groups, except for P-1695. Cytochalasin D, which inhibits actin polymerization changed the F-actin staining: dotlike aggregations appeared in the actin ring at the level of tight junctions and in the basal area (Appendix, Pub. III, Fig. S3). Triton X-100 surfactant disrupted the plasma membrane and the structure of the microvilli at apical surface (Appendix, Pub. III, Fig. S3). The junctional actin ring was mostly preserved, but aggregations were observed in the junctional and basal areas.

The ultrastructure of TJs between Caco-2 cells was preserved in all treatment groups (Fig. 17b). No morphological change was seen by electron microscopy in the structure of apical microvilli, TJs, desmosomes, or interdigitations of adjacent epithelial cells. No open Tjs were observed in the control or treatment groups by checking 140 electron micrographs (19-28 images/treatment group). 


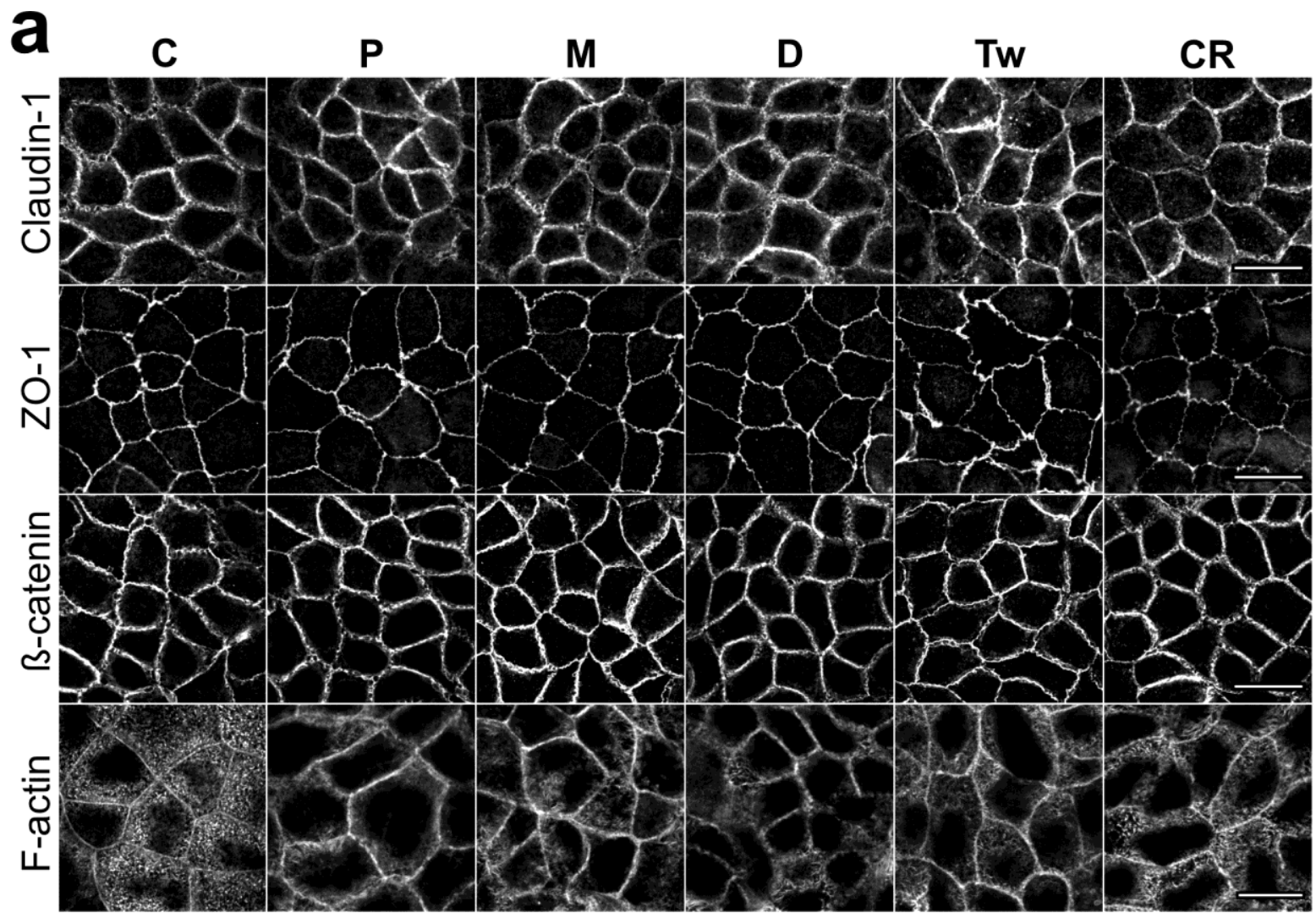

b
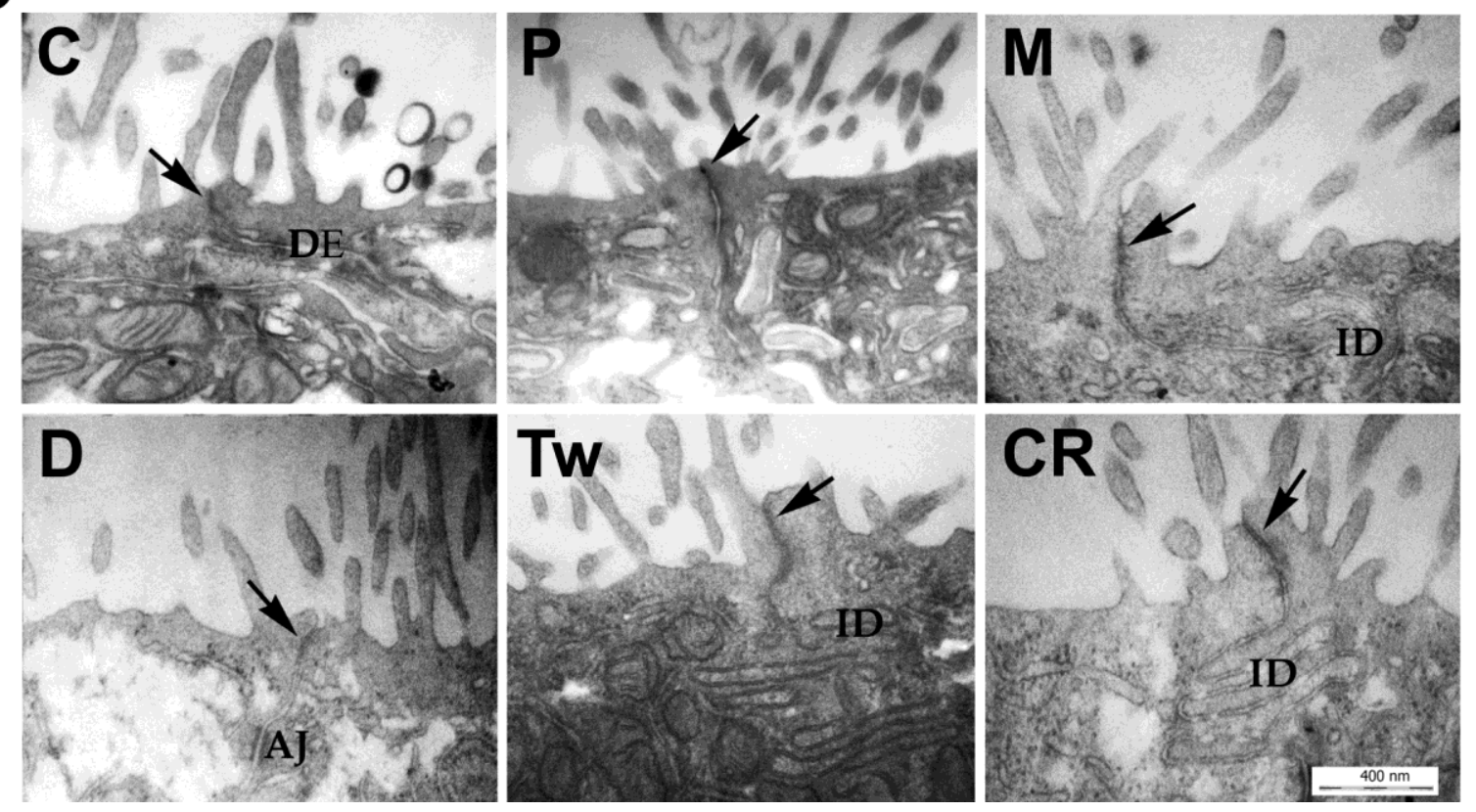

Figure 17. Effect of surfactants on cellular and junctional morphology, fluorescent immunostainings and electron microscopy. (a) Immunostaining for tight and adherens junction membrane proteins claudin-1, ZO-1 and $\beta$ catenin and fluorescent staining for F-actin microfilaments in human Caco-2 intestinal epithelial cells after 1 hour treatment with sucrose esters and reference absorption enhancers. Bar for claudin-1, ZO-1 and $\beta$-catenin is $20 \mu \mathrm{m}$ and for F-actin is $15 \mu \mathrm{m}$. (b) Transmission electron microscopy at cell-cell connections after 1 hour treatment with sucrose esters and reference absorption enhancers; bar $=400 \mathrm{~nm}$. Applied concentrations: $P$ 1695, $30 \mu \mathrm{g} / \mathrm{ml}$; M-1695, $60 \mu \mathrm{g} / \mathrm{ml}$; D-1216, $100 \mu \mathrm{g} / \mathrm{ml}$; Tween 80, $1000 \mu \mathrm{g} / \mathrm{ml}$; Cremophor RH40, $1000 \mu \mathrm{g} / \mathrm{ml}$. Abbreviations: C, control; P, P-1695; M, M-1695; D, D-1216; Tw, Tween 80; CR, Cremophor RH40; ZO-1, zonula occludens protein-1; arrow: tight junction; AJ: adherens junction; DE: desmosome; ID: interdigitation. 


\subsection{Effects of sucrose esters and reference surfactants on epithelial cell membranes}

The membrane fluidity of living epithelial cells was determined by the measurement of fluorescence anisotropy of the cationic membrane probe TMA-DPH (Fig. 18). The anisotropy slightly decreased from $0.293 \pm 0.002$ to $0.286 \pm 0.001$ in vehicle-treated Caco- 2 cells after 20 minutes. The membrane fluidizer benzyl alcohol quickly and greatly reduced the anisotropy: TMA-DPH fluorescence anisotropy fell to $90.2 \%$ compared to control after 3 minutes. Sucrose esters fluidized the plasma membrane of Caco-2 cells at all applied concentrations (Fig. 18a). A U-shaped dose-response curve was observed for all sucrose esters. The biggest change in the anisotropy compared to the control group was measured at $10 \mu \mathrm{g} / \mathrm{ml}$ of P-1695 (92.0\%), $30 \mu \mathrm{g} / \mathrm{ml}$ of M-1695 (91.9\%) and $60 \mu \mathrm{g} / \mathrm{ml}$ of D-1216 (96.1\%). At higher concentrations higher anisotropy was observed, indicating reduced membrane fluidity.
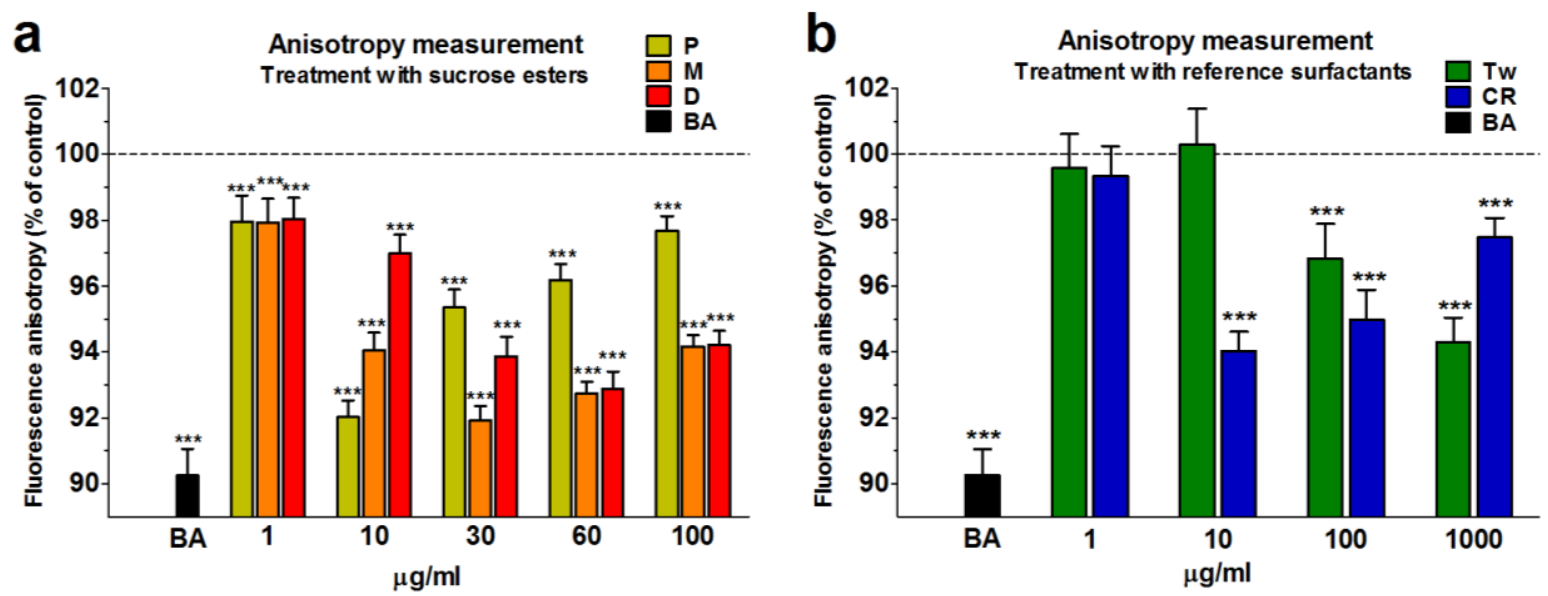

Figure 18. The effect on plasma membrane fluidity of (a) sucrose esters, (b) reference absorption enhancers and benzyl alcohol measured by TMA-DPH fluorescence anisotropy on living Caco-2 cell suspensions. The anisotropy values in control cells were between $0.293 \pm 0.002$ and $0.286 \pm 0.002$ during the observation, and control value was considered as $100 \%$. Data are presented as mean \pm S.D., $n=6$; statistical analysis: two way ANOVA followed by Bonferroni posttest; ${ }^{* * *} P<0.001$, all groups were compared to control. Applied concentrations of sucrose esters: $1,10,30,60,100 \mu \mathrm{g} / \mathrm{ml}$; treatment concentrations of reference surfactants: 1 , $10,100,1000 \mu \mathrm{g} / \mathrm{ml}$. Benzyl alcohol was used at $30 \mathrm{mM}$ concentration. Abbreviations: P, P-1695; M, M-1695; D, D-1216; Tw, Tween 80; CR, Cremophor RH40; BA, benzyl alcohol.

The reference absorption enhancers at $1 \mu \mathrm{g} / \mathrm{ml}$ concentration did not alter significantly membrane fluidity in contrast to sucrose esters (Fig. 18b). Tween 80 at $10 \mu \mathrm{g} / \mathrm{ml}$ was also ineffective, but at $100 \mu \mathrm{g} / \mathrm{ml}$ and higher concentrations statistically significantly fluidized the plasma membrane of epithelial cells with lowest anisotropy at $1000 \mu \mathrm{g} / \mathrm{ml}(94.2 \%)$. Cremophor RH40 was the most effective at $10 \mu \mathrm{g} / \mathrm{ml}$ concentration (94.0\%). Higher concentrations of the reference surfactants were also less effective to reduce membrane anisotropy. 


\subsection{Effects of sucrose esters and reference surfactants on efflux pump activity}

Efflux transporter activity in Caco-2 cells was measured by the cellular uptake of calcein AM, the cellular uptake and bidirectional transport of rhodamine 123, a ligand of P-gp and BCRP (Schinkel et al., 2003), and bidirectional permeability of vinblastine (Fig. 19). Coadministration of surfactants and rhodamine 123 resulted in statistically significant increase in the uptake of rhodamine (Fig. 19a). M-1695 and Tween 80 caused the highest, six-fold accumulation of the marker molecule compared to control. Co-administration of sucrose esters and calcein AM significantly elevated the uptake of the ligand (200-245\%) (Fig. 19b). Co-treatment with Tween $80(1000 \mu \mathrm{g} / \mathrm{ml})$ also significantly increased the cellular accumulation of calcein AM. In contrast to rhodamine 123 uptake, Cremophor RH40 had no effect on calcein AM uptake (Fig. 19b). Verapamil $(100 \mu \mathrm{M})$ and cyclosporin A $(10 \mu \mathrm{M})$ significantly raised the level of both ligands in Caco-2 cells (Fig. 19a-b).

a

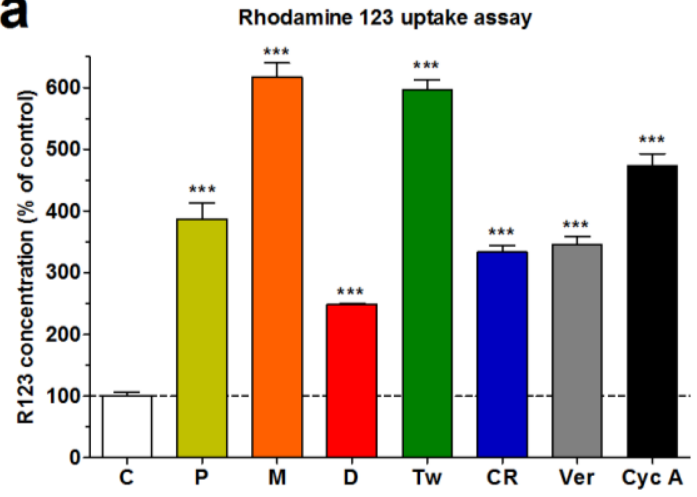

C

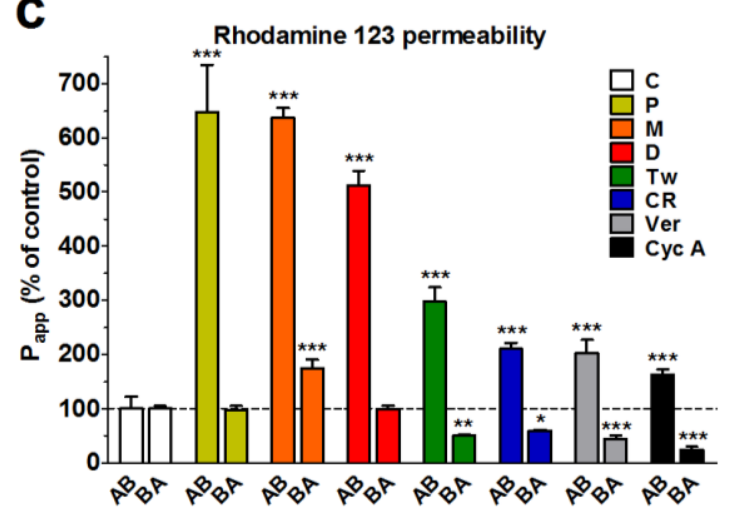

b
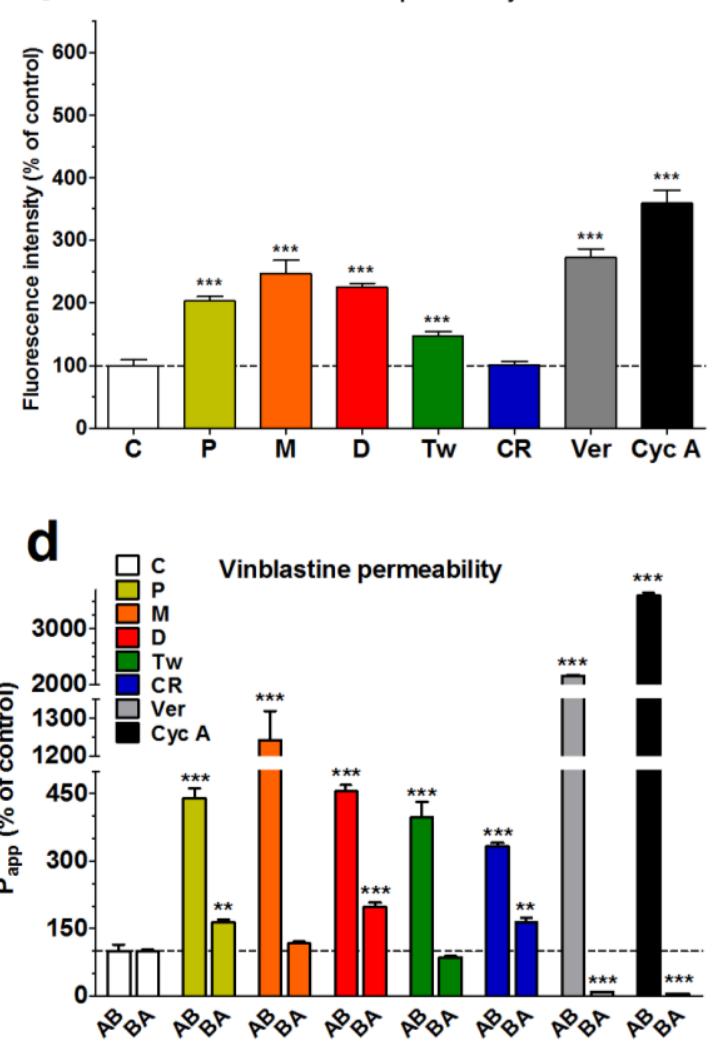

Figure 19. The effects of absorption enhancers on efflux pump activity measured by ligand accumulation and permeability studies. The accumulation of (a) rhodamine 123, and (b) calcein AM was determined in co-treatment with sucrose esters, reference absorption enhancers, inhibitors verapamil and cyclosporine A on Caco-2 cells. The effects of surfactants on the apparent permeability coefficients of (c) rhodamine 123 and (d) vinblastine in two directions were measured on Caco-2 cell layers. Data are presented as mean \pm S.D., $n=3-6$; statistical analysis: ANOVA followed by Dunnett test (a-b) or two-way ANOVA followed by Bonferroni test (c-d); ${ }^{*} P<0.05$, ${ }^{* *} P<0.01$, ${ }^{\star * *} P<0.001$, all groups were compared to control. Applied concentrations: P-1695, $30 \mu \mathrm{g} / \mathrm{ml} ; \mathrm{M}-1695,60 \mu \mathrm{g} / \mathrm{ml}$; D-1216, $100 \mu \mathrm{g} / \mathrm{ml}$; Tween 80, $1000 \mu \mathrm{g} / \mathrm{ml}$; Cremophor RH40, $1000 \mu \mathrm{g} / \mathrm{ml}$; verapamil, $100 \mu \mathrm{M}$; cyclosporine A, $10 \mu \mathrm{M}$. Abbreviations: $\mathrm{P}_{\mathrm{app}}$, apparent permeability coefficient; R123, Rhodamine 123; C, control; P, P-1695; M, M-1695; D, D-1216; Tw, Tween 80; CR, Cremophor RH40; Ver, verapamil; Cyc A, cyclosporine A. 
Rhodamine 123 permeability in $\mathrm{AB}$ direction was significantly enhanced by both absorption enhancers and efflux pump inhibitors as compared to control group $\left(0.82 \pm 0.18 \times 10^{-}\right.$ ${ }^{6} \mathrm{~cm} / \mathrm{s}$ ) (Fig. 19c). Treatments with sucrose esters resulted in several fold elevated AB flux of the marker molecule as compared to reference surfactants or efflux pump inhibitors. The transport of rhodamine 123 in BA direction was unchanged by P-1695 and D-1216, but increased by M1695. In contrast, reference absorption enhancers and efflux pump inhibitors significantly decreased rhodamine 123 efflux transport (Fig. 19c). The permeability of vinblastine, a ligand of P-gp and MRP-2 efflux pumps (Hellinger et al., 2012), was measured in both directions in the absence $\left(\mathrm{AB}: 0.33 \times 10^{-6} \mathrm{~cm} / \mathrm{s}\right.$; BA: $52.45 \times 10^{-6}$ ) or presence of surfactants (Fig. 19d). All treatments increased the flux of drug in $\mathrm{AB}$ direction by several fold, and M-1695 sucrose ester had the most pronounced enhancer effect. P-1695 palmitate and D-1216 laurate esters, and Cremophor also elevated vinblastine penetration in BA direction. Verapamil and cyclosporine A reduced the drug transport in BA direction, but Tween 80 did not.

Surfactants were also tested on MES-SA/Dx5 cells overexpressing P-gp and the parental (P-gp negative) MES-SA cell line (Fig. 20). Cells with enhanced membrane permeability were gated out by TO-PRO3 staining, therefore in this assay only P-gp inhibition was detected. The calcein accumulation observed in the absence of P-gp in MES-SA cells was not influenced by treatments. Due to the high level expression of P-gp, MES-SA/Dx5 cells showed reduced calcein accumulation. The P-gp-inhibitor verapamil $(100 \mu \mathrm{M})$ increased the fluorescent dye uptake to the level of the control cell line. Except for Tween 80, the surfactants did not influence the accumulation of calcein in this assay, indicating a lack of interaction with P-gp.
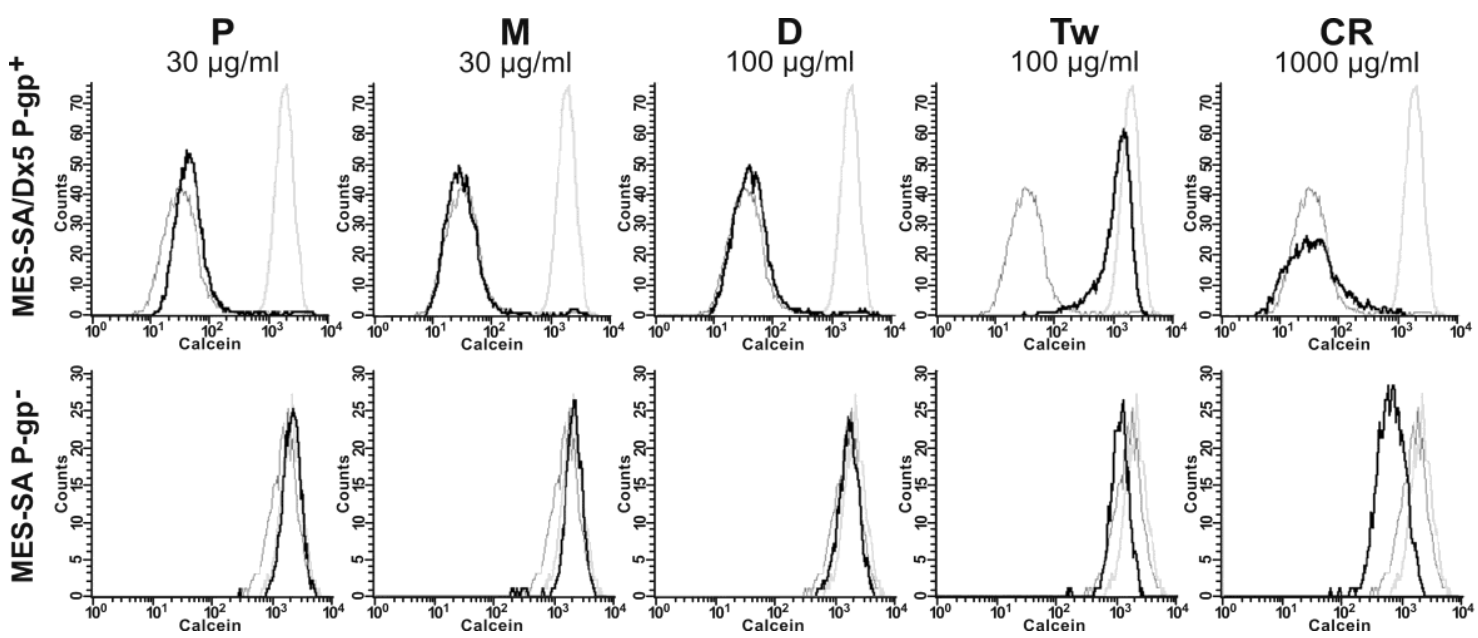

Figure 20. Effect of surfactants on calcein AM accumulation in P-gp positive MES-SA/Dx5 and P-gp negative MES-SA cell lines. Cellular calcein AM fluorescence was determined after the treatments with vehicle (dark gray), verapamil (light gray), and surfactants (black) and is shown in histogram. Applied concentrations: P-1695, $30 \mu \mathrm{g} / \mathrm{ml} ; \mathrm{M}-1695$, $30 \mu \mathrm{g} / \mathrm{ml} ; \quad$ D-1216, $100 \mu \mathrm{g} / \mathrm{ml}$; Tween 80, $100 \mu \mathrm{g} / \mathrm{ml}$; Cremophor RH40, $1000 \mu \mathrm{g} / \mathrm{ml}$; Verapamil, $100 \mu \mathrm{M}$. Abbreviations: C, control; M, M-1695; P, P-1695; D, D-1216; Tw, Tween 80; CR, Cremophor RH40; Ver, verapamil. The assay was repeated three times; the histograms show data from a representative experiment. 


\section{DISCUSSION}

The use of absorption enhancers is important for improving drug bioavailability. The effects of pharmaceutical excipients may substantially differ and thorough knowledge about absorption enhancers is needed to develop better drug formulations. In the present $\mathrm{PhD}$ work selected surface active agents with solubilizer and absorption enhancer properties were investigated on cell culture models. New data were obtained on the effects and toxicity of the well-known and clinically applied excipients, Cremophor RH40 and Cremophor EL using in vitro culture models of intestinal and vascular barriers. The effects of three water soluble sucrose esters, palmitate, myristate, and laurate were also tested on cellular toxicity, drug permeability, intercellular junction morphology, efflux pump activity and plasma membrane fluidity, giving a more complex and detailed view on their action on cultured intestinal epithelial cells than previous works and compared to reference surfactants Tween 80 and Cremophor RH40.

\subsection{Surfactants and cellular toxicity}

Due to their amphiphilic properties surfactants can easily interact with cell membranes, perturb or disrupt the lipid bilayer. This effect depending on applied concentration and treatment time can be reversible (Anderberg et al., 1992) but higher concentrations may thin or rupture plasma membranes, damage the microvilli in the apical surface of cells, and lead to leakage of intracellular proteins or cell death (Anderberg et al., 1992; Hamid et al., 2009; Sakai et al., 1998). These adverse effects can be reduced by choosing appropriate surfactants for drug formulation or by lowering their concentrations to safe levels.

\subsubsection{Comparison of the effects of Cremophor RH40 and EL on viability of intestinal epithelial and vascular endothelial cells}

The use of Cremophor EL in various dosage forms is accompanied by many adverse reactions (Gelderblom et al., 2001), and understanding the side-effects of Cremophor EL is essential for safety reasons. The toxicity of Cremophor RH40 is less well known and examined, but it is also important because of its application in oral solutions and soft gelatin capsules (Strickley, 2004).

In our study the cytotoxicity of Cremophors was tested in epithelial and endothelial cells using concentrations corresponding to clinical administration. The concentrations of Cremophor RH40 and EL in oral formulations ranges from 25 to 405 and 2 to $600 \mathrm{mg}$, respectively (FDA database for Inactive Ingredients in Approved Drug Products). The maximal dose of Neoral, containing Cremophor RH40 is $15 \mathrm{mg} / \mathrm{kg}$ bodyweight/day in 2 
equal doses, therefore Cremophor RH40 may reach $4.5 \mathrm{mg} / \mathrm{ml}$ or higher concentrations in the stomach. It should be considered that patients may take Cremophor containing drugs chronically, for months or years. Cremophor EL concentrations in the blood can reach $5 \mathrm{mg} / \mathrm{ml}$ after infusions of Taxol or Sandimmun (Gelderblom et al., 2001) and this level can be maintained for 3-24 hours.

Human intestinal epithelial cells were damaged by the Cremophors in concentration dependent manner. These results are in agreement with previous works indicating impairment of viability in Caco-2 cells treated with Cremophors (Karpf et al., 2006; Maroju et al., 2010). The kinetics of the toxicity of Cremophor RH40 and EL on human endothelial cells was also demonstrated in the present work. The clinically observed side-effects might be related to changes in the viability and monolayer integrity of endothelial cells exerted by Cremophors.

An unexpected effect was seen in epithelial cells treated with surfactants using MTT assay and impedance measurement. The dye conversion and monolayer impedance were transiently increased in higher concentrations of both excipients. Such a change was also observed in endothelial cells, but it lasted only for one hour. MTT assay involves several cellular processes (Liu et al., 1997), which may be influenced by Cremophors. The increased MTT dye conversion may reflect higher metabolic activity or changes in endocytosis of dye and exocytosis of formazan crystals. Activation of different $G$ protein-coupled receptors in various mammalian cells lead to changes in cell shape and attachment resulting in a transient increase in impedance values (Atienza et al., 2006). The effect of Cremophors on metabolic activity, or endocytosis, or $\mathrm{G}$ protein-coupled receptors in epithelial or endothelial cells may cause this phenomenon and further experiments are needed to reveal this interaction.

Endothelial cells were more sensitive than epithelial cells for treatments with Cremophor RH40 and EL. Short term incubations with Cremophors resulted in changes only in endothelial but not in epithelial cells based on impedance measurement. Cremophors, similarly to other surfactants have a profound influence on cell membranes, disturb lipid bilayer (Hugger et al., 2002) or remove certain lipids from the membranes (Groot et al., 2001). Differences in the membrane lipid composition and in lipid rafts (Dias et al., 1992; Héliès-Toussaint et al., 2006; Simons et al., 2000) of epithelial and endothelial cells may be related to our observations on the divergent effects of Chremophors on these cell types.

Cremophor RH40 was less toxic than EL in cultured epithelial and endothelial cells. Our data are in agreement with findings on K-562 lymphoid cell line (Kristmundsdóttir et al., 2002). The reason of the differences in the toxicity of the Cremophors is unknown. Distinct characteristics in the molecular structures may be related to the observed results (Fig. 5). Cremophor EL contains a double bond, which is not present in Cremophor RH40. Double bonds are more reactive than single covalent bonds in general, and may result in 
higher cytotoxic effect. The higher lipophilicity of EL (HLB:12-14) than RH40 (HLB: 16) may also cause higher perturbation in cell membranes, and this effect can be connected to the critical micellar concentration (Christiansen et al., 2010), which is lower in case of Cremophor EL than that of RH40.

\subsubsection{Effects of sucrose esters and reference surfactants on epithelial cellular viability}

Investigation of sucrose fatty acid esters on Caco-2 cells revealed that D-1216 laurate ester (carbon chain length: 12) was the least toxic, while myristate (carbon chain length: 14) and palmitate (carbon chain length: 16) esters had higher toxicity at both 1- and 24-hour treatments. Similar results were obtained by these sucrose esters in the previous work of the research group on RPMI 2650 human nasal epithelial cell line (Kürti et al, 2012). The same range of non-toxic concentrations were described for an unspecified sucrose monoester in Caco-2 cells (Mine et al., 2003), and for sucrose laurate, Tween 80 and Cremophor RH40 on MDCK dog kidney cells and two MDCK derived cell lines (Hanke et al., 2010). The toxic concentrations of the reference surfactants Tween 80 and Cremophor RH40 are at least one order of magnitude higher than that of sucrose esters in our studies and in the literature indicating that reference molecules have a safer toxicity profile on cultured cells than sucrose esters.

In contrast to cell culture works sucrose esters did not damage palatal and buccal pork tissues (Ganem-Quintanar et al., 1998). Sucrose fatty acid esters are hydrolyzed by intestinal enzymes into sucrose and fatty acids in animal studies and their metabolites were not toxic (Berry et al., 1960; Noker et al., 1997; Shigeoka et al., 1984). In addition, sucrose esters are hydrolyzed under acidic or basic conditions (Christiansen et al., 2011; Okumura et al., 2011) and bacterial lipases can disintegrate them (Marciello et al., 2011). Tween 80, Cremophor RH40 and Cremophor EL are also degraded in the intestine or in the blood (Christiansen et al., 2010; van Tellingen et al., 1999), but the effects of the metabolites are unknown. A recent review drew the attention to the dangers of using surfactants as food additives because their permeability enhancing and efflux pump inhibitor properties may cause intestinal barrier dysfunction and increase the incidence of allergic and autoimmune diseases (Csáki, 2011), but conclusive animal studies and human data are missing. Despite the results of cell culture tests and the hypothesized dangers of surfactants ingested as additives in large quantities from foodstuff, the animal studies suggest that the toxicity of sucrose esters might be lower, if any, when given orally in small quantities as excipients. However, further chronic toxicity experiments are needed to prove the safety of sucrose esters as potential oral excipients. 


\subsection{Non-ionic surfactants and drug absorption}

It is widely known that surface active agents can improve the absorption of drugs (Deli, 2009; Aungs, 2000 and 2012; Renukuntla et al., 2013) but the mechanisms are not fully explored. The present investigation aimed to reveal the pathways affected by the selected surfactants to induce absorption enhancement. Various methods were used to determine the effect of sucrose esters, Tween 80 and Cremophor RH40 on the para- and transcellular permeability of drugs and tracers.

Sucrose esters decreased the resistance and impedance of epithelial cell layers reflecting elevated ion penetration through the paracellular and transcellular pathways, respectively. Resistance of Caco-2 cell layer also dropped after treatment with sucrose esters in other studies (Mine et al., 2003). Reference surfactants did not change TEER of Caco-2 monolayers in the present experiments and in two independent studies (Takahashi et al., 2002; Yu et al., 2011), indicating no paracellular barrier opening. The resistance and impedance measurements suggest that sucrose esters enhance ion permeability through paraand trancellular pathways.

We described for the first time that sucrose esters elevated the flux of the hydrophilic drug atenolol through Caco-2 cell layers, indicating the absorption enhancer properties of these surfactants. The tested excipients significantly increased the penetration of fluorescein in a concentration dependent manner in the $\mathrm{AB}$ direction. Since treatments were applied apically, similarly to per os drug administration, moderate or no permeability enhancement was observed in the opposite direction. The absorption enhancing effects of sucrose esters (Szüts et al., 2012), especially laurate was demonstrated in several in vivo investigations (Ganem-Quintanar et al., 1998; Lerk et al., 1993; Nakada et al., 1988; Onishi et al., 2012). Tween 80 and Cremophor RH40 increased fluorescein permeability only in higher concentrations, therefore sucrose esters are more effective in small concentrations. Reference surfactants enhanced the permeability of all compounds, except the lipophilic model drugs caffeine and antipyrine. These class I compounds of the Biopharmaceutics Classification System are highly soluble and have high permeability (Wu et al., 2005), and the tested surfactants could not elevate further the already high permeability. Both Tween 80 and Cremophor RH40 are excipients in medicines (Tw: Fluxarix, Boostrix, Tubersol, Tripedia; CR: Neoral) and their penetration increasing effects in the present study are in agreement with literature data (Horvát et al., 2009; Kürti et al., 2012; Nerurkar et al., 1997; Rege et al., 2001; Takahashi et al., 2002).

Immunostaining of junctional proteins, fluorescent labeling of F-actin and transmission electron microscopy were used to visualize intercellular connections and demonstrate the integrity of the paracellular barrier. It was observed for the first time that sucrose esters, 
Tween 80 and Cremophor RH40 did not cause any major change in the distribution of immunostaining for junctional proteins claudin-1, ZO- 1 and $\beta$-catenin on Caco- 2 cells at the applied concentrations. Surfactants slightly changed the organization of F-actin at the junctional region and basal part of the cells, but did not cause visible opening of the junctions. This F-actin redistribution can be linked to changes in the functional permeability of the junctions (Deli, 2009). Cytoskeletal F-actin changes caused by an undefined sucrose ester were also observed in Caco-2 cells (Mine et al., 2003). Surfactants did not change the morphology of TJs investigated by electron microscopy. No disruption of junctions or cell layers were observed by these morphological examinations confirming the safety of the selected surfactant concentrations and that sucrose esters do not cause visible damage of intercellular junctions.

The effect of sucrose esters on cell membranes was suggested (Hanke et al., 2010), but it was not investigated in living cells yet. The selected sucrose esters fluidized the plasma membrane of Caco- 2 cells at lower concentrations than reference absorption enhancers, and caused stronger TMA-DPH fluorescence anisotropy reduction than Tween 80 or Cremophor RH40. Sucrose esters containing longer fatty acid chain increased better the membrane fluidity at lower concentrations, indicating a correlation between the length of fatty acid chain and effect on membrane fluidity. The maximal fluidization concentrations did not coincide with the maximal permeability enhancer effect of the surfactants. Several factors influence the membrane permeability of cells, including the fluidity of lipid bilayers, plasma membrane thickness and elasticity, and pore formation in the lipid layer (Lichtenberger et al., 2006; Peetla et al., 2013). This study focused on membrane fluidization, but other changes in cell membrane properties could contribute to the observed penetration enhancer effects. Other studies confirmed that surfactants, including our reference excipients, increase the fluidity of cellular plasma membranes, which is linked to enhanced membrane permeability and changes in the activity of membrane transporters and efflux pumps (Aungst, 2000; Rege et al., 2002; Nerurkar et al., 1997).

The resistance, impedance, permeability, morphology and membrane fluidity measurements indicate that several mechanisms are involved in the absorption enhancer effect of sucrose esters (Fig. 21). All the tested surfactants elevated plasma membrane fluidity, which can contribute to increased transcellular passage of molecules. Sucrose esters decreased both resistance and impedance indicating an effect on the function of intercellular junctions and cellular membranes, thus enhancing drug permeability through both the transand paracellular routes. Tween 80 and Cremophor RH40 changed neither the morphology of intercellular junctions, nor the resistance of cell layers, suggesting no effect on paracellular transport. 


\subsection{Non-ionic surfactants and efflux pumps}

Efflux transporters hinder drug delivery across biological barriers and blocking these pumps is considered as a way to increase drug penetration (Darby et al., 2011). Surfactants were described to inhibit uptake transporters (Engel et al., 2012) as well as efflux pumps (Bogman et al., 2003; Hugger et al., 2002). The effect of sucrose esters on efflux pumps is contradictory with studies describing inhibitory (Cornaire et al., 2004; Hanke et al., 2010) or no effect (Takaishi et al., 2006). In the present experiments sucrose esters, unlike inhibitors or reference surfactants, increased the permeability of vinblastine and rhodamine 123 in $\mathrm{AB}$, but not in the other direction, suggesting no inhibitory effect on efflux pumps. Sucrose esters elevated rhodamine 123 and calcein AM accumulation in co-treatment, which may have suggested an inhibitory effect of efflux transporters. However, our experiments conducted on a model cell line expressing $\mathrm{P}$-gp ruled out this possibility, as the sucrose esters did not influence the P-gp-mediated efflux in MES-SA/Dx5 cells. Takaishi et al. suggested that elevated daunomycine flux in Caco-2 cells caused by sucrose esters is due to permeabilization of the cellular membrane (Takaishi et al., 2006), but our work is the first to experimentally prove that enhanced permeability is unrelated to P-gp inhibition.

Reference surfactants significantly increased the accumulation of rhodamine 123. The uptake of calcein AM in Caco-2 cells was increased by Tween 80 and efflux pump inhibitors, but not by Cremophor RH40. The difference in the rhodamine and calcein AM uptake assays may be explained by the different specificity of the dyes: rhodamine 123 is a ligand of P-gp and BCRP while calcein AM is a ligand of P-gp, MRP-1 and -2 (Hanke et al., 2010; Schinkel et al., 2003). Reference surfactants significantly increased the penetration of rhodamine 123 and vinblastine in $\mathrm{AB}$ direction, but reduced the permeability in the other direction only for rhodamine. Vinblastine is a ligand of both P gp and MRP-2 which may explain the difference. Calcein AM uptake in P-gp expressing MES-SA/Dx5 cells verified that Tween 80 is a P-gp inhibitor. Our data indicate an inhibitory effect of the reference surfactants on efflux pump activity (Fig. 21) in agreement with other studies on Tween 80 (Gelderblom et al., 2001; Cornaire et al., 2004; Hanke et al., 2010; Nerurkar et al., 1997; Engel et al., 2012) and Cremophor RH40 (Hanke et al., 2010; Yamagata et al., 2007). 


\subsection{Conclusion}

The effects of pharmaceutical excipients, Cremophor RH40 and EL on the viability of human intestinal epithelial and vascular endothelial cells were compared for the first time. Cremophor RH40 was less toxic than Cremophor EL in both cell types. Endothelial cells were more sensitive than intestinal epithelial cells to treatments with Cremophors. The observed changes in endothelial cells may be related to the side effects of Cremophor EL in vivo.

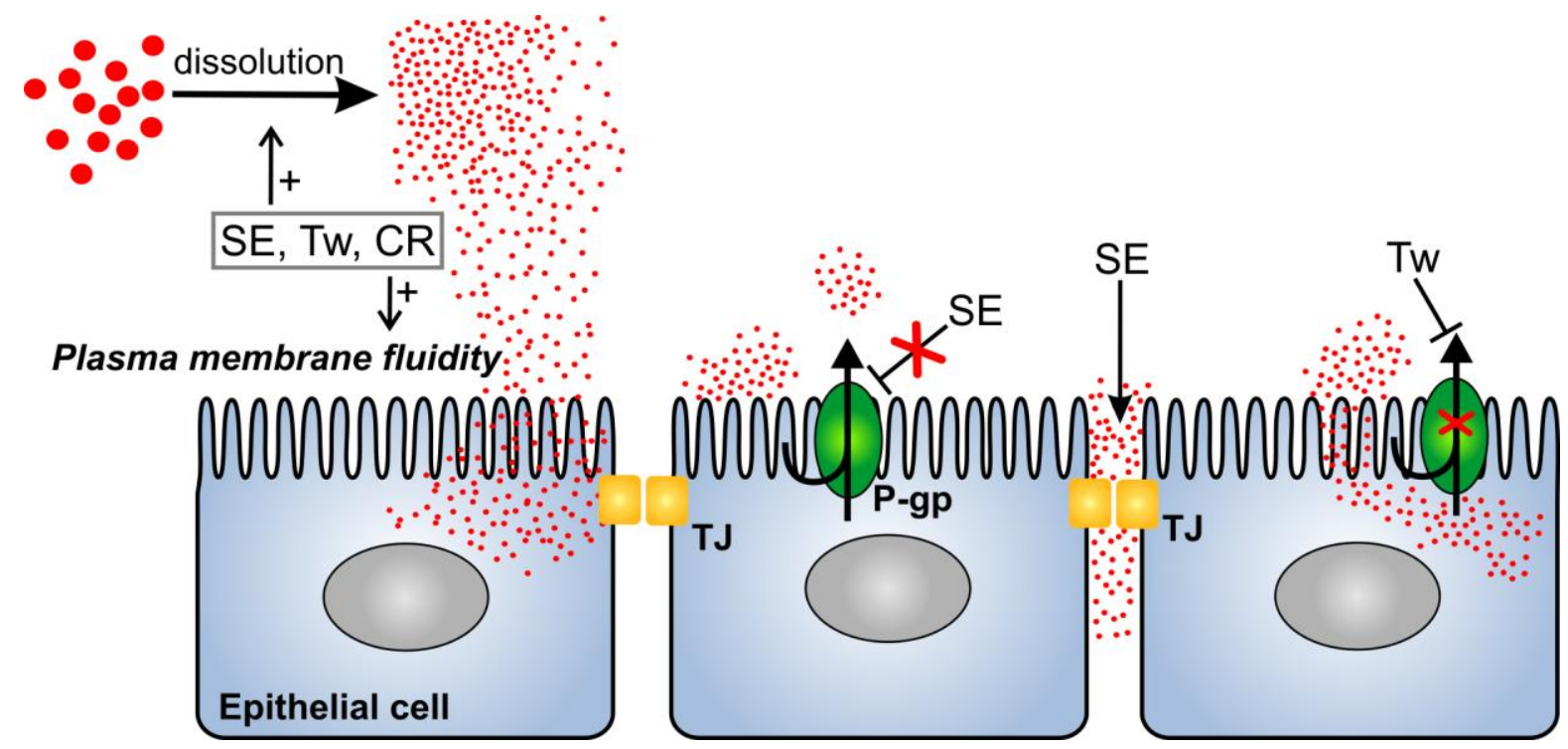

Figure 21. How sucrose esters, Tween 80 and Cremophor RH40 enhance permeability in epithelial cells? Sucrose esters and reference absorption enhancers may increase the penetration of molecules in several ways. (i) Surfactants enhance the dissolution of molecules and change plasma membrane fluidity which contribute to enhanced delivery of agents. (ii) Tween 80, but not sucrose esters, inhibits P-glycoprotein. (iii) Sucrose esters may alter the function but not the visible morphology of cellular junctions, while reference molecules have no effect. Abbreviations: CR, Cremophor RH40; P-gp, P-glycoprotein; SE, sucrose esters; TJ, tight junction; Tw, Tween 80.

Sucrose esters are increasingly used as inactive ingredients in pharmaceutical products. Our study on cultured epithelial cells confirmed, that sucrose esters are effective absorption enhancers for both hydrophilic drugs and efflux pump ligands. Sucrose esters enhance drug penetration by the trans- and paracellular routes, but do not inhibit P-glycoprotein (Fig. 21). It was demonstrated for the first time that sucrose esters fluidize the plasma membrane of epithelial cells in low concentrations. Reference surfactants Tween 80 and Cremophor RH40 increase drug penetration by the transcellular pathway and inhibition of efflux pump activity and not by acting on intercellular junctions. Sucrose esters as oral excipients may act differently than the reference absorption enhancers, therefore further studies are needed to optimize oral dosage forms with these surfactants. 


\section{SUMMARY}

Surfactants used in pharmaceutical products have several advantageous properties; they improve drug absorption and dissolution, and protect active molecules. However, adverse effects are also observed during the application of different surface active agents which necessitates the investigation of registered surfactants and novel absorption enhancer candidates.

Cremophor RH40 and EL are widely used excipients in oral and intravenous drug formulations. Studies indicate that Cremophors, especially EL, have toxic side effects, but few data are available on endothelial and epithelial cells which form biological barriers and are directly exposed to these molecules. In our investigation human intestinal epithelial and vascular endothelial cells were treated with Cremophor RH40 and EL in clinically relevant concentrations and their toxic effect was monitored by several methods. Cremophors caused concentration- and time-dependent damage in both epithelial and endothelial cells. Endothelial cells were more sensitive to surfactant treatment than epithelial cells, and Cremophor EL was more toxic than RH40 in both cell types. Our results support and complement the previously experimentally described toxic effects of Cremophor EL which may be related to the clinically recognized side-effects of medicines containing Cremophor EL. Sucrose fatty acid esters are increasingly investigated as novel excipients in pharmaceutical research and some of them are registered in Pharmacopoeias both in the European Union and in the United States. Several studies documented their advantageous properties but few data are available on their toxicity profile, mode of action and efficacy on intestinal epithelial models. Three water soluble sucrose esters, palmitate (P-1695), myristate (M-1695), laurate (D-1216), and two reference absorption enhancers, Tween 80 and Cremophor RH40 were tested on human Caco-2 intestinal epithelial cells. Sucrose esters in non-toxic concentrations significantly reduced resistance and impedance of cells, but not reference surfactants. All excipients increased permeability for drugs and fluidized plasma membrane, but did not visibly open tight junctions. Tween 80 but not sucrose esters inhibit P-glycoprotein. Our data indicate that in addition to their dissolution increasing properties sucrose esters can enhance drug permeability through both the transcellular and paracellular routes but this effect is unrelated to P-glycoprotein inhibition.

The presented results demonstrate the differences between the cellular actions of various non-ionic surfactant excipients, which can be important for the development of new pharmaceutical formulations and drug delivery systems. 


\section{REFERENCES}

Allen TM, Cullis PR. 2004. Drug delivery systems: entering the mainstream. Science 303:1818-1822.

Anderberg EK, Nyström C, Artursson P. 1992. Epithelial transport of drugs in cell culture. VII: Effects of pharmaceutical surfactant excipients and bile acids on transepithelial permeability in monolayers of human intestinal epithelial(Caco-2) cells. J Pharm Sci 81:879-887.

Antosova Z, Mackova M, Kral V, Macek T. 2009. Therapeutic application of peptidesand proteins: parenteral forever? Trends Biotechnol 27:628-635.

Artursson P, Borchardt RT. 1997. Intestinal drug absorption and metabolism in cell cultures: Caco-2 and beyond. Pharm Res 14:1655-8.

Artursson P, Palm K, Luthman K. 2001. Caco-2 monolayers in experimental and theoretical predictions of drug transport. Adv Drug Deliv Rev 46:27-43.

Atienza JM., Yu N, Kirstein SL, Xi B, Wang X, Xu X, Abassi YA. 2006. Dynamic and label-free cell-based assays using the real-time cell electronic sensing system. Assay Drug Dev Technol 4:597-607.

Aungst BJ. 2000. Intestinal permeation enhancers. J Pharm Sci 89:429-442. Review.

Aungst BJ. 2012. Absorption enhancers: applications and advances. AAPS J. 14:10-18.

Balogh G, Maulucci G, Gombos I, Horváth I, Török Z, Péter M, Fodor E, Páli T, Benkő S, Parasassi T, De Spirito M, Harwood JL, Vígh L. 2011. Heat stress causes spatially-distinct membrane remodelling in K562 leukemia cells. PLoS One 6:e21182.

Berry J, Turner D. 1960. The enzymatic hydrolysis and tissue oxidation of fatty acid esters of sucrose. J Am Oil Chem Soc 37:302-305.

Benson K, Cramer S, Galla HJ. 2013. Impedance-based cell monitoring: barrier properties and beyond. Fluids Barriers CNS 10:5.

Bogman K, Erne-Brand F, Alsenz J, Drewe J. 2003. The role of surfactants in the reversal of active transport mediated by multidrug resistance proteins. J Pharm Sci 92:1250-1261.

Buclin T, Cosma Rochat M, Burckhardt P, Azria M, Attinger M. 2002. Bioavailability and biological efficacy of a new oral formulation of salmon calcitonin in healthy volunteers. J Bone Miner Res 17:1478-1485.

Cao FH, OuYang WQ, Wang YP, Yue PF, Li SP. 2011. A combination of a microemulsion and a phospholipid complex for topical delivery of oxymatrine. Arch Pharm Res 34:551-562.

Chen G, Jaffrézou JP, Fleming WH, Durán GE, Sikic BI. 1994. Prevalence of multidrug resistance related to activation of the mdr1 gene in human sarcoma mutants derived by single-step doxorubicin selection. Cancer Res 54:4980-4987.

Chiba H, Osanai M, Murata M, Kojima T, Sawada N. 2008. Transmembrane proteins of tight junctions. Biochim Biophys Acta 1778:588-600.

Christiansen A, Backensfeld T, Weitschies W. 2010. Effects of non-ionic surfactants on in vitro triglyceride digestion and their susceptibility to digestion by pancreatic enzymes. Eur J Pharm Sci 41:376-382.

Christiansen A, Backensfeld T, Denner K, Weitschies W. 2011. Effects of non-ionic surfactants on cytochrome P450-mediated metabolism in vitro. Eur J Pharm Biopharm 78:166-172.

Collett A, Sims E, Walker D, He YL, Ayrton J, Rowland M, Warhurst G. 1996. Comparison of HT29-18-C1 and Caco-2 cell lines as models for studying intestinal paracellular drug absorption. Pharm Res 13:216-221.

Cornaire G, Woodley J, Hermann P, Cloarec A, Arellano C, Houin G. 2004. Impact of excipients on the absorption of P-glycoprotein substrates in vitro and in vivo. Int J Pharm 278:119-131. 
Csáki KF. 2011. Synthetic surfactant food additives can cause intestinal barrier dysfunction. Med Hypotheses 76:676-681.

Csóka G, Marton S, Zelko R, Otomo N, Antal I. 2007. Application of sucrose fatty acid esters in transdermal therapeutic systems. Eur J Pharm Biopharm 65:233-237.

Darby RA, Callaghan R, McMahon RM. 2011. P-glycoprotein inhibition: the past, the present and the future. Curr Drug Metab 12:722-731.

Daudé D, Remaud-Siméon M, André I. 2012. Sucrose analogs: an attractive (bio)source for glycodiversification. Nat Prod Rep 29:945-960.

Deák K, Takács-Novák K, Tihanyi K, Noszál B. 2006. Physico-chemical profiling of antidepressive sertraline: solubility, ionisation, lipophilicity. Med Chem 2:385-389.

Deli MA. 2009. Potential use of tight junction modulators to reversibly open membranous barriers and improve drug delivery. Biochim Biophys Acta 1788:892-910.

Deli M. 2011. Drug Transport and the Blood-Brain Barrier. Solubility, Delivery and ADME Problems of Drugs and Drug Candidates, 2011, 144-165. Editors: Vastag M, Tihanyi K

Dias VC, Wallace JL, Parsons HG. 1992. Modulation of cellular phospholipid fatty acids and leukotriene B4 synthesis in the human intestinal cell (CaCo-2). Gut 33:622-627.

Dredán J, Zelkó R, Bihari E, Rácz I, Gondár E. 1998. Effect of polysorbates on drug release from wax matrices. Drug Dev Ind Pharm 24:573-576.

Engel A, Oswald S, Siegmund W, Keiser M. 2012. Pharmaceutical excipients influence the function of human uptake transporting proteins. Mol Pharm 9:2577-2581.

Englund G, Rorsman F, Rönnblom A, Karlbom U, Lazorova L, Gråsjö J, Kindmark A, Artursson P. 2006. Regional levels of drug transporters along the human intestinal tract: co-expression of ABC and SLC transporters and comparison with Caco-2 cells. Eur J Pharm Sci 29:269-277.

Fedina LT, Zelkó R, Fedina LI, Szabados Z, Szántó M. 1998. Comparative evaluation of surfactant and hydrophobizing agent concentration in relation to the optimal particle size of metered-dose inhalers. Drug Dev Ind Pharm 24:853-856.

Flaten GE, Luthman K, Vasskog T, Brandl M. 2008. Drug permeability across a phospholipid vesicle-based barrier 4 . The effect of tensides, co-solvents and $\mathrm{pH}$ changes on barrier integrity and on drug permeability. Eur J Pharm Sci 34:173-180.

Ganem-Quintanar A, Kalia YN, Falson-Rieg F, Buri P. 1997. Mechanisms of oral permeation enhancement. Int J Pharm, 156:127-142.

Ganem-Quintanar A, Quintanar-Guerrero D, Falson-Rieg F, Buri P. 1998. Ex vivo oral mucosal permeation of lidocaine hydrochloride with sucrose fatty acid esters as absorption enhancers. Int $\mathbf{J}$ Pharm 173:203-210.

Gelderblom H, Verweij J, Nooter K, Sparreboom A. 2001. Cremophor EL: the drawbacks and advantages of vehicle selection for drug formulation. Eur J Cancer 37:1590-1598.

Ghosh C, Gonzalez-Martinez J, Hossain M, Cucullo L, Fazio V, Janigro D, Marchi N. 2010. Pattern of P450 expression at the human blood-brain barrier: roles of epileptic condition and laminar flow. Epilepsia 51:1408-1417.

Giacomini KM, Huang SM, Tweedie DJ, Benet LZ, Brouwer KL, Chu X, Dahlin A, Evers R, Fischer V, Hillgren KM, Hoffmaster KA, Ishikawa T, Keppler D, Kim RB, Lee CA, Niemi M, Polli JW, Sugiyama Y, Swaan PW, Ware JA, Wright SH, Yee SW, Zamek-Gliszczynski MJ, Zhang L. 2010. Membrane transporters in drug development. Nat Rev Drug Discov 9:215-236.

Groot RD, Rabone KL. 2001. Mesoscopic simulation of cell membrane damage, morphology change and rupture by nonionic surfactants. Biophys J 81:725-736.

Gursoy RN, Benita S. 2004. Self-emulsifying drug delivery systems (SEDDS) for improved oral delivery of lipophilic drugs. Biomed Pharmacother 58:173-182. 
Hamid KA, Katsumi H, Sakane T, Yamamoto A. 2009. The effects of common solubilizing agents on the intestinal membrane barrier functions and membrane toxicity in rats. Int J Pharm 379:100108.

Hanke U, May K, Rozehnal V, Nagel S, Siegmund W, Weitschies W. 2010. Commonly used nonionic surfactants interact differently with the human efflux transporters ABCB1 (pglycoprotein) and ABCC2 (MRP2). Eur J Pharm Biopharm 76:260-268.

Héliès-Toussaint C, Gambert S, Roller P, Tricot S, Lacour B, Grynberg A. 2006. Lipid metabolism in human endothelial cells. Biochim Biophys Acta 1761:765-774.

Hellinger E, Bakk ML, Pócza P, Tihanyi K, Vastag M. 2010. Drug penetration model of vinblastinetreated Caco-2 cultures. Eur J Pharm Sci 41:96-106.

Hellinger E, Veszelka S, Tóth AE, Walter F, Kittel A, Bakk ML, Tihanyi K, Háda V, Nakagawa S, Duy TD, Niwa M, Deli MA, Vastag M. 2012. Comparison of brain capillary endothelial cellbased and epithelial (MDCK-MDR1, Caco-2, and VB-Caco-2) cell-based surrogate blood-brain barrier penetration models. Eur J Pharm Biopharm 82:340-351.

Hermann DM, Bassetti CL. 2007. Implications of ATP-binding cassette transporters for brain pharmacotherapies. Trends Pharmacol Sci 28:128-134.

Horvát S, Fehér A, Wolburg H, Sipos P, Veszelka S, Tóth A, Kis L, Kurunczi A, Balogh G, Kürti L, Eros I, Szabó-Révész P, Deli MA. 2009. Sodium hyaluronate as a mucoadhesive component in nasal formulation enhances delivery of molecules to brain tissue. Eur J Pharm Biopharm 72:252-259.

Honeywell-Nguyen PL, Bouwstra JA. 2003. The in vitro transport of pergolide from surfactant-based elastic vesicles through human skin: a suggested mechanism of action. J Control Release 86:145-156.

Hubatsch I, Ragnarsson EG, Artursson P. 2007. Determination of drug permeability and prediction of drug absorption in Caco-2 monolayers. Nat Protoc 2:2111-2119.

Hugger ED, Novak BL, Burton PS, Audus KL, Borchardt RT. 2002. A comparison of commonly used polyethoxylated pharmaceutical excipients on their ability to inhibit P-glycoprotein activity in vitro. J Pharm Sci 91:1991-2002.

Juvale K, Pape VF, Wiese M. 2012. Investigationof chalcones and benzochalcones as inhibitors of breast cancer resistance protein. Bioorg Med Chem 20:346-355.

Karászi E, Jakab K, Homolya L, Szakács G, Holló Z, Telek B, Kiss A, Rejtô L, Nahajevszky S, Sarkadi B, Kappelmayer J. 2001. Calcein assay for multidrug resistance reliably predicts therapy response and survival rate in acute myeloid leukaemia. Br J Haematol 112:308-314.

Karpf DM, Holm R, Garafalo C, Levy E, Jacobsen J, Müllertz A. 2006. Effect of different surfactants in biorelevant medium on the secretion of a lipophilic compound in lipoproteins using Caco-2 cell culture. J Pharm Sci 95:45-55.

Kepp O, Galluzzi L, Lipinski M, Yuan J, Kroemer G. 2011. Cell death assays for drug discovery. Nat Rev Drug Discov 10:221-237.

Kiss T, Fenyvesi F, Kovácsné BI, Fehér P, Leposáné KR, Váradi J, Szente L, Fenyvesi E, Iványi R, Vecsernyés M. 2007. Cytotoxic examinations of various cyclodextrin derivatives on Caco-2 cells. Acta Pharm Hung 77:150-154.

Klang V, Matsko N, Raupach K, El-Hagin N, Valenta C. 2011. Development of sucrose stearatebased nanoemulsions and optimisation through $\gamma$-cyclodextrin. Eur J Pharm Biopharm 79:58-67.

Krause G, Winkler L, Mueller SL, Haseloff RF, Piontek J, Blasig IE. 2008. Structure and function of claudins. Biochim Biophys Acta 1778:631-645.

Kristmundsdóttir T, Aradóttir HA, Ingólfsdóttir K, Ogmundsdóttir HM. 2002. Solubilization of the lichen metabolite (+)-usnic acid for testing in tissue culture. J Pharm Pharmacol 54:1447-1452.

Kürti L, Gáspár R, Márki Á, Kápolna E, Bocsik A, Veszelka S, Bartos C, Ambrus R, Vastag M, Deli MA, Szabó-Révész P. 2013. In vitro and in vivo characterization of meloxicam nanoparticles designed for nasal administration. Eur J Pharm Sci 50:86-92. 
Lafforgue G, Arellano C, Vachoux C, Woodley J, Philibert C, Dupouy V, Bousquet-Mélou A, Gandia P, Houin G. 2008. Oral absorption of ampicillin: role of paracellular route vs. PepT1 transporter. Fundam Clin Pharmacol 22:189-201.

Legen I, Kristl A. 2004. D-glucose triggers multidrug resistance-associated protein (MRP)-mediated secretion of fluorescein across rat jejunum in vitro. Pharm Res 21:635-640.

Lennernäs H. 2007. Intestinal permeability and its relevance for absorption and elimination. Xenobiotica 37:1015-1051.

Lerk P, Sucker H. 1993. Application of sucrose laurate, a new pharmaceutical excipient, in peroral formulations of cyclosporin A. Int J Pharm 92:197-202.

Lichtenberger LM, Zhou Y, Dial EJ, Raphael RM. 2006. NSAID injury to the gastrointestinal tract: evidence that NSAIDs interact with phospholipids to weaken the hydrophobic surface barrier and induce the formation of unstable pores in membranes. J Pharm Pharmacol 58:1421-1428.

Liu Y, Peterson DA, Kimura H, Schubert D. 1997. Mechanism of cellular 3-(4,5-dimethylthiazol-2yl)-2,5-diphenyltetrazolium bromide (MTT) reduction. J Neurochem 69:581-593.

Loftsson T, Vogensen SB, Brewster ME, Konrádsdóttir F. 2007. Effects of cyclodextrins on drug delivery through biological membranes. J Pharm Sci 96:2532-46.

Marciello M, Mateo C, Guisan JM. 2011. Full enzymatic hydrolysis of commercial sucrose laurate by immobilized-stabilized derivatives of lipase from Thermomyces lanuginosa. Colloids Surf B Biointerfaces 84:556-560.

Maroju RK, Turner DC, Zhang H. 2010. Solubilizing efficiency and in vitro cytotoxicity of peptoad G. J Pharm Sci 99:2196-2198.

Masaoka Y, Tanaka Y, Kataoka M, Sakuma S, Yamashita S. 2006. Site of drug absorption after oral administration: assessment of membrane permeability and luminal concentration of drugs in each segment of gastrointestinal tract. Eur J Pharm Sci 29:240-250.

Meaney CM, O'Driscoll CM. 2000. A comparison of the permeation enhancement potential of simple bile salt and mixed bile salt:fatty acid micellar systems using the CaCo-2 cell culture model. Int $\mathrm{J}$ Pharm 207:21-30.

Mercke Odeberg J, Lignell A, Pettersson A, Höglund P. 2003. Oral bioavailability of the antioxidant astaxanthin in humans is enhanced by incorporation of lipid based formulations. Eur J Pharm Sci 19:299-304.

Miller JM, Dahan A, Gupta D, Varghese S, Amidon GL. 2010. Enabling the intestinal absorption of highly polar antiviral agents: ion-pair facilitated membrane permeation of zanamivir heptyl ester and guanidino oseltamivir. Mol Pharm 7:1223-1234.

Mine Y, Zhang JW. 2003. Surfactants enhance the tight-junction permeability of food allergens in human intestinal epithelial Caco-2 cells. Int Arch Allergy Immunol 130:135-142.

Molinier V, Fenet B, Fitremann J, Bouchu A, Queneau Y. 2005. PFGSE-NMR study of the selfdiffusion of sucrose fatty acid monoesters in water. J Colloid Interface Sci 286:360-368.

Nakada Y, Awata N, Nakamichi C, Sugimoto I. 1988. The effect of additives on the oral mucosal absorption of human calcitonin in rats. J Pharmacobiodyn 11:395-401.

Narang AS, Delmarre D, Gao D. 2007. Stable drug encapsulation in micelles and microemulsions. Int J Pharm 345:9-25.

Nerurkar MM, Ho NF, Burton PS, Vidmar TJ, Borchardt RT. 1997. Mechanistic roles of neutral surfactants on concurrent polarized and passive membrane transport of a model peptide in Caco-2 cells. J Pharm Sci 86:813-821.

Noker PE, Lin TH, Hill DL, Shigeoka T. 1997. Metabolism of 14C-labelled sucrose esters of stearic acid in rats. Food Chem Toxicol 35:589-595.

Okumura H, Kitazawa N, Wada S, Hotta H. 2011. Stability of sucrose fatty acid esters under acidic and basic conditions. J Oleo Sci 60:313-320. 
Onishi H, Imura Y, Uchida M, Machida Y. 2012. Enhancement potential of sucrose laurate (L-1695) on intestinal absorption of water-soluble high molecular weight compounds. Curr Drug Deliv 9:487-494.

Oravcová J, Böhs B, Lindner W. 1996. Drug-protein binding sites. New trends in analytical and experimental methodology. J Chromatogr B Biomed Appl 677:1-28.

Ózsvári B, Puskás L, Nagy L. 2010. A cell-microelectronic sensing technique for the screening of cytoprotective compounds. Int J Mol Med 25:525-530.

Pardridge WM. 2012. Drug transport across the blood-brain barrier. J Cereb Blood Flow Metab 32:1959-1972.

Peetla C, Vijayaraghavalu S, Labhasetwar V. 2013. Biophysics of cell membrane lipids in cancer drug resistance: Implications for drug transport and drug delivery with nanoparticles. Adv Drug Deliv Rev 65:1686-1698.

Peura L, Malmioja K, Huttunen K, Leppänen J, Hämäläinen M, Forsberg MM, Gynther M, Rautio J, Laine K. 2013. Design, synthesis and brain uptake of LAT1-targeted amino acid prodrugs of dopamine. Pharm Res 30:2523-2537.

Qiu Y, Park K. 2001. Environment-sensitive hydrogels for drug delivery. Adv Drug Deliv Rev 53:321-339.

Rege BD, Yu LX, Hussain AS, Polli JE. 2001. Effect of common excipients on Caco-2 transport of low-permeability drugs. J Pharm Sci 90:1776-1786.

Renukuntla J, Vadlapudi AD, Patel A, Boddu SH, Mitra AK. 2013. Approaches for enhancing oral bioavailability of peptides and proteins. Int J Pharm 447:75-93.

Rhee YS, Choi JG, Park ES, Chi SC. 2001. Transdermal delivery of ketoprofen using microemulsions. Int J Pharm 228:161-170.

Sakai M, Imai T, Ohtake H, Azuma H, Otagiri M. 1998. Effects of absorption enhancers on cytoskeletal actin filaments in Caco-2 cell monolayers. Life Sci 63:45-54.

Sakeer K, Al-Zein H, Hassan I, Desai S, Nokhodchi A. 2010. Enhancement of dissolution of nystatin from buccoadhesive tablets containing various surfactants and a solid dispersion formulation. Arch Pharm Res 33:1771-1779.

Sarmento B, Ribeiro A, Veiga F, Ferreira D, Neufeld R. 2007. Oral bioavailability of insulin contained in polysaccharide nanoparticles. Biomacromolecules 8:3054-3060.

Savić S, Tamburić S, Savić MM. 2010. From conventional towards new - natural surfactants in drug delivery systems design: current status and perspectives. Expert Opin Drug Deliv 7:353-369.

Schinkel AH, Jonker JW. 2003. Mammalian drug efflux transporters of the ATP binding cassette (ABC) family: an overview. Adv Drug Deliv Rev 55:3-29.

Seelig A. 2007. The role of size and charge for blood-brain barrier permeation of drugs and fatty acids. J Mol Neurosci 33:32-41.

Shigeoka T, Izawa O, Kitazawa K, Yamauchi F, Murata T. 1984. Studies on the metabolic fate of sucrose esters in rats. Food Chem Toxicol 22:409-414.

Simons K, Toomre D. 2000. Lipid rafts and signal transduction. Nat Rev Mol Cell Biol 1:31-39.

Smith JM, Dornish M, Wood EJ. 2005. Involvement of protein kinase C in chitosan glutamatemediated tight junction disruption. Biomaterials 26:3269-3276.

Sonoda N, Furuse M, Sasaki H, Yonemura S, Katahira J, Horiguchi Y, Tsukita S. 1999. Clostridium perfringens enterotoxin fragment removes specific claudins from tight junction strands: Evidence for direct involvement of claudins in tight junction barrier. J Cell Biol 147:195-204.

Strickley RG. 2004. Solubilizing excipients in oral and injectable formulations. Pharm Res 21:201-230. 
Sugano K, Kansy M, Artursson P, Avdeef A, Bendels S, Di L, Ecker GF, Faller B, Fischer H, Gerebtzoff G, Lennernaes H, Senner F. 2010. Coexistence of passive and carrier-mediated processes in drug transport. Nat Rev Drug Discov 9:597-614.

Swenson ES, Curatolo W. 1992. (C) Means to enhance penetration:(2) Intestinal permeability enhancement for proteins, peptides and other polar drugs: mechanisms and potential toxicity. Adv Drug Deliv Rev 8:39-92.

Szüts A, Szabó-Révész P. 2012. Sucrose esters as natural surfactants in drug delivery systems--a mini-review. Int J Pharm 433:1-9.

Takahashi Y, Kondo H, Yasuda T, Watanabe T, Kobayashi S, Yokohama S. 2002. Common solubilizers to estimate the Caco-2 transport of poorly water-soluble drugs. Int J Pharm 246:85-94.

Takaishi N, Satsu H, Shimizu M. 2006. Enhanced daunomycin accumulation in human intestinal Caco-2 cells from non-ionic food emulsifiers unrelated to the P-glycoprotein inhibitory mechanism. Biosci Biotechnol Biochem 70:2703-2711.

Thevenin MA, Grossiord JL, Poelman MC. 1996. Sucrose esters/cosurfactant microemulsion systems for transdermal delivery: assessment of bicontinuous structures. Int J Pharm 137:177-186.

Török Z, Horváth I, Goloubinoff P, Kovács E, Glatz A, Balogh G, Vígh L. 1997. Evidence for a lipochaperonin: association of active protein-folding GroESL oligomers with lipids can stabilize membranes under heat shock conditions. Proc Natl Acad Sci USA 94: 2192-2197

Türk D, Hall M D, Chu B F, Ludwig J A, Fales H M, Gottesman M M, Szakács G. 2009. Identification of compounds selectively killing multidrug-resistant cancer cells. Cancer Res 69:8293-8301.

van Tellingen O, Beijnen JH, Verweij J, Scherrenburg EJ, Nooijen WJ, Sparreboom A. 1999. Rapid esterase-sensitive breakdown of polysorbate 80 and its impact on the plasma pharmacokinetics of docetaxel and metabolites in mice. Clin Cancer Res 5:2918-2924.

Vastag M, Keseru GM. 2009. Current in vitro and in silico models of blood-brain barrier penetration: a practical view. Curr Opin Drug Discov Devel 12:115-124.

Veszelka S, Pásztói M, Farkas AE, Krizbai I, Ngo TK, Niwa M, Abrahám CS, Deli MA. 2007. Pentosan polysulfate protects brain endothelial cells against bacterial lipopolysaccharide-induced damages. Neurochem Int 50:219-28.

Ward PD, Tippin TK, Thakker DR. 2000. Enhancing paracellular permeability by modulating epithelial tight junctions. Pharm Sci Technolo Today 3:346-358.

Weis M, Mortensen SA, Rassing MR, Møller-Sonnergaard J, Poulsen G, Rasmussen SN. 1994. Bioavailability of four oral coenzyme Q10 formulations in healthy volunteers. Mol Aspects Med 15 Suppl:s273-s280.

Weksler B, Romero IA, Couraud PO. 2013. The hCMEC/D3 cell line as a model of the human blood brain barrier. Fluids Barriers CNS 10:16

Williams AC, Barry BW. 2004. Penetration enhancers. Adv Drug Deliv Rev 56:603-18.

Wu CY, Benet LZ. 2005. Predicting drug disposition via application of BCS: transport/absorption/ elimination interplay and development of a biopharmaceutics drug disposition classification system. Pharm Res 22:11-23.

Yamagata T, Kusuhara H, Morishita M, Takayama K, Benameur H, Sugiyama Y. 2007. Effect of excipients on breast cancer resistance protein substrate uptake activity. J Control Release 124:1-5.

Yokoi Y, Yonemochi E, Terada K. 2005. Effects of sugar ester and hydroxypropyl methylcellulose on the physicochemical stability of amorphous cefditoren pivoxil in aqueous suspension. Int $\mathbf{J}$ Pharm 290:91-99.

Yu H, Hu YQ, Ip FC, Zuo Z, Han YF, Ip NY. 2011. Intestinal transport of bis(12)-hupyridone in Caco-2 cells and its improved permeability by the surfactant Brij-35. Biopharm Drug Dispos $32: 140-150$. 
Zhao X, Liu JP, Zhang X, Li Y. 2006. Enhancement of transdermal delivery of theophylline using microemulsion vehicle. Int J Pharm 327:58-64.

\section{Online links}

FDA Guidance for Industry, Drug Interaction Studies, 2012, link: http://www.fda.gov/downloads/Drugs/GuidanceComplianceRegulatoryInformation/Guidances/UCM2 92362.pdf

FDA database for Inactive Ingredients in Approved Drug Products, link: http://www.accessdata.fda.gov/scripts/cder/iig/ 


\section{ACKNOWLEDGEMENT}

I am grateful to my supervisors and mentors, Dr. Mária Deli and Prof. Piroska SzabóRévész for their scientific guidance, encouragement and support throughout my PhD studies.

I thank Prof. Pál Ormos, director of the Biological Research Centre, and Dr. László Siklós, head of the Molecular Neurobiology Research Unit for their support.

I am indebted to our cooperating partners, Dr. Monika Vastag and Dr. Éva Hellinger for permeability measurements; Dr. László Puskás and Dr. Béla Ózsvári for real-time cell microelectronic sensing; Dr. Ágnes Kittel for electronmicroscopical studies; Dr. Zsolt Török and Dr. Ana-Maria Pilbat for membrane fluidization measurements; Dr. Gergő Szakács and András Füredi for measurements of P-glycoprotein functionality.

I am grateful to Dr. Sándor Horvát, Dr. Levente Kürti, Fruzsina Walter, Alexandra Bocsik, Petra Sántha, András Harazin, Dr. Szilvia Veszelka, Andrea Tóth, Dr. Péter Sipos, Ngo Thi Khue Dung, Erik Glässer, Ilona Gróf for their inspiring help during the experiments.

I also thank the members of the Molecular Neurobiology Research Unit for their help and friendship.

Finally, I am especially thankful to my wife, Kata, my mother, my aunt and the rest of my family for their love and untiring support during my studies.

The research was supported by grants from the Social Renewal Operational Programme (TÁMOP-4.2.2-08/1-2008-0013; TÁMOP-4.2.1/B-09/1/KONV-2010-0005; TÁMOP-4.2.2/B-10/1-2010-2012; TÁMOP-4.2.2.A-11/1/KONV-2012-0052; TÁMOP4.2.2.A-11/1/KONV-2012-0035; TÁMOP-4.1.1.C-12/1/KONV-2012-0012). The financial support of the Hungarian Academy of Sciences in the form of a 3-year fellowship and Ányos Jedlik Fellowship program (TÁMOP 4.2.4. A/2-11-1-2012-0001) is gratefully acknowledged. 


\section{APPENDIX}




\section{PUBLICATION I.}


Provided for non-commercial research and education use. Not for reproduction, distribution or commercial use.

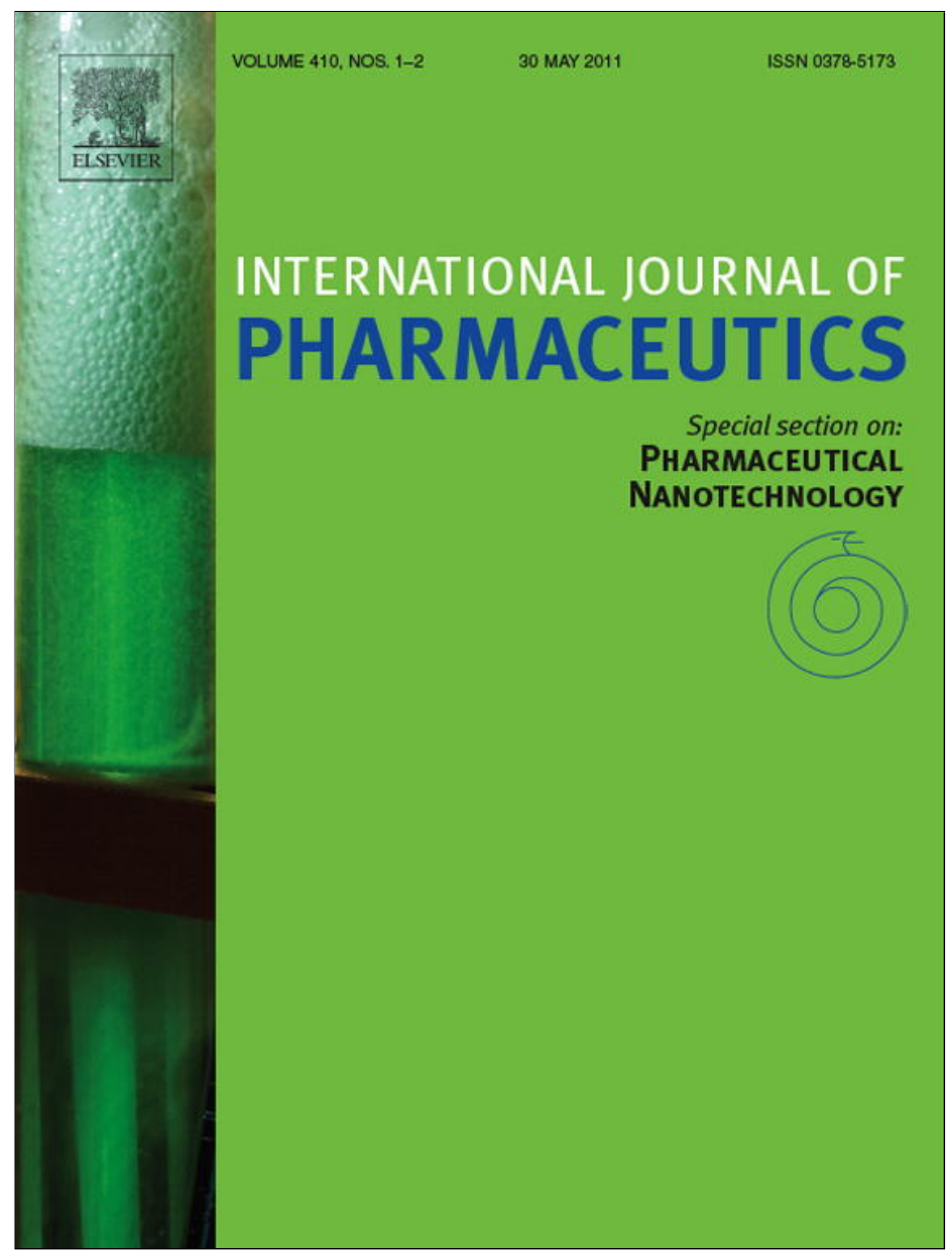

This article appeared in a journal published by Elsevier. The attached copy is furnished to the author for internal non-commercial research and education use, including for instruction at the authors institution and sharing with colleagues.

Other uses, including reproduction and distribution, or selling or licensing copies, or posting to personal, institutional or third party websites are prohibited.

In most cases authors are permitted to post their version of the article (e.g. in Word or Tex form) to their personal website or institutional repository. Authors requiring further information regarding Elsevier's archiving and manuscript policies are encouraged to visit:

http://www.elsevier.com/copyright 
Rapid communication

\title{
Applicability of sucrose laurate as surfactant in solid dispersions prepared by melt technology
}

\author{
Angéla Szüts a , Péter Láng ${ }^{\mathrm{a}}$, Rita Ambrus ${ }^{\mathrm{a}}$, Lóránd Kiss ${ }^{\mathrm{a}, \mathrm{b}}$, Mária A. Deli ${ }^{\mathrm{b}}$, Piroska Szabó-Révész ${ }^{\mathrm{a}, *}$ \\ a Department of Pharmaceutical Technology, University of Szeged, H-6720 Szeged, Eötvös u. 6, Hungary \\ ${ }^{\mathrm{b}}$ Laboratory of Molecular Neurobiology, Institute of Biophysics, Biological Research Center, Hungarian Academy of Sciences, H-6726 Szeged, Temesvári krt. 62., Hungary
}

\section{A R T I C L E I N F O}

\section{Article history:}

Received 16 December 2010

Received in revised form 7 March 2011

Accepted 13 March 2011

Available online 21 March 2011

\section{Keywords}

Sucrose laurate

Surfactant

Solid dispersion

Melt technology

Cytotoxicity

Caco-2 cells

Gemfibrozil

PEG 6000

\begin{abstract}
A B S T R A C T
This study focused on an investigation of the applicability of sucrose laurate as surfactant in solid dispersions. Although this surfactant has a US Drug Master File, it has not been used so far in internal pharmaceutical products. High drug-loaded solid dispersion systems consisting of gemfibrozil as a model drug and PEG 6000 as a carrier, with or without sucrose laurate (D1216), were prepared by the melting method. Cytotoxicity studies on Caco-2 monolayer cells were also performed, in order to gain information on the applicability of D1216 in oral formulations. The results showed that the presence of the surfaceactive agent did not affect the solid-state characteristics of the model drug significantly. A markedly improved dissolution of gemfibrozil from the ternary solid dispersion systems was observed as compared with the binary solid dispersion systems. The optimum concentration range of the D1216 in the formulations was determined to be $5-10 \%$. The effective final concentrations of D1216 in the dissolution experiments proved to be non-toxic towards $\mathrm{CaCo}-2$ cells. The results suggest the potential use of D1216 in innovative internal pharmaceutical formulations.
\end{abstract}

(c) 2011 Elsevier B.V. All rights reserved.
The poor water solubility of drug substances and their low rates of dissolution in the aqueous gastrointestinal fluids often lead to insufficient bioavailability, and this remains a problem to the pharmaceutical industry. Solid dispersions of hydrophobic drugs in water-soluble carriers have attracted considerable interest as a means of improving dissolution behaviour, and hence enhancing bioavailability. Water-soluble carriers such as high-molecularweight polyethylene glycols (PEGs) and polyvinylpyrrolidones (PVPs) have been most commonly used for solid dispersions (Bikiaris et al., 2005; Craig and Newton, 1991; Leuner and Dressman, 2000; Saharan et al., 2009; Serajuddin, 1999). The use of surfactants with solubilizing properties, such as polysorbates, poloxamers, Gelucires (polyethylene glycol glycerides), sodium lauryl sulfate or vitamin E TPGS have also attracted considerable interest recently (Dehghan and Jafar, 2006; Jagdale et al., 2010; Liu and Wang, 2007; Mura et al., 1999; Okonogi and Puttipipatkhachorn, 2006; Owusu-Ababio et al., 1998; Sethia and Squillante, 2002; Vasconcelos et al., 2007). As described in the review by Vasconcelos et al. (2007), the third-generation solid dispersion systems contain a surfactant carrier, or a mixture of amorphous polymers and surfactants as carriers. These thirdgeneration solid dispersions are intended to achieve the highest degree of bioavailability for poorly soluble drugs. The inclusion

\footnotetext{
* Corresponding author. Tel.: +36 6254 5572; fax: +36 62545571.

E-mail address: revesz@pharm.u-szeged.hu (P. Szabó-Révész).
}

of surfactants in the solid dispersions may help to avoid drug recrystallization and to stabilize the systems (Vasconcelos et al., 2007).

Sucrose esters (SEs) are widely used in the food and cosmetics industries, and there has recently been great interest in their applicability in different pharmaceutical fields. They are biodegradable, natural, non-ionic surface-active agents consisting of sucrose as hydrophilic moiety and fatty acids as lipophilic groups (AbdElbary et al., 2008; Csóka et al., 2007; Ganem Quintanar et al., 1998; Okamoto et al., 2005; Otomo, 2009; Ntawukulilyayo et al., 1993; Shibata et al., 2002).

In an earlier study we investigated, the structure and thermal behaviour of SE in order to predict their applicability in hot melt technology (Szüts et al., 2007). Our results revealed that SEs are semicrystalline carriers, with both amorphous and crystalline regions. During the preparation of solid dispersions, the drugs are built into the amorphous phases of the SEs (Szüts et al., 2008). In melt technology, mainly the lipophilic SEs may be suggested as carriers. They display characteristic melting, whereas SEs with high or moderate HLB values only soften during heating (Szüts et al., 2007). It has also been found that hydrophilic SEs exhibit gelling behaviour at body temperatures, which can influence the drug release (Szüts et al., 2010a,b). In view of these results, the applicability of hydrophilic SEs alone as carriers in hot melt technology is not suggested. Dispersion or dissolution of the drugs in the softened SEs is difficult, and a high amount of swelling SEs can reduce the rate of dissolution of a drug. 
The aim of the present study was to evaluate the applicability of hydrophilic sucrose ester as surfactant in third-generation solid dispersion systems together with a polymer. As carrier, the commonly used PEG 6000 was chosen, with which the hydrophilic $(H L B=16)$ sucrose laurate showed the best miscibility among the evaluated sucrose esters (sucrose-stearate, -palmitate and laurate). Although this surfactant has a US Drug Master File, it has so far not been used in internal pharmaceutical products. In this work, studies on the cytotoxicity of sucrose laurate on Caco-2 monolayer cells were also performed, in order to gain information on its availability in oral formulations.

Gemfibrozil (GEM), a poorly water-soluble $(29.1 \mu \mathrm{g} / \mathrm{ml}$ at $\mathrm{pH}=6.2 \pm 0.1$ ) model drug, was supplied by TEVA (Hungary). PEG 6000, the carrier used in our experiments, was from Hungaropharma (Hungary). Sucrose laurate D1216 $(\mathrm{HLB}=16)$ was kindly provided by Harke Pharma $\mathrm{GmbH}$ (Germany).

During the sample production, $40 \% \mathrm{w} / \mathrm{w}$ of GEM was always applied. In the case of the binary systems, PEG 6000 was heated at $70^{\circ} \mathrm{C}$ in a sand bath and, after melting, the appropriate amount of GEM was added. In dispersions incorporating surfactant $(1 \%, 5 \%$, $10 \%$ or $15 \% \mathrm{w} / \mathrm{w}$ ), D 1216 was dissolved in the melted carrier prior to the addition of GEM. The molten mixture was stirred manually for $15 \mathrm{~min}$, to achieve homogeneous dispersion of the drug. The melts were quickly cooled to $-10^{\circ} \mathrm{C}$ in a freezer, after which the solidified samples were pulverized in a mortar and sieved to $200 \mu \mathrm{m}$.

The physical states of the GEM in the different samples were evaluated by XRPD with a Miniflex II X-ray Diffractometer (Rigaku Co. Tokyo, Japan), where the tube anode was Cu with $K \alpha=1.5405 \AA$. Patterns were collected with a tube voltage of $30 \mathrm{kV}$ and a tube current of $15 \mathrm{~mA}$ in step scan mode $\left(4^{\circ} / \mathrm{min}\right)$. The instrument was calibrated by using Si.

The release of the model drug was studied by using Pharmatest equipment (Hainburg, Germany) at a paddle speed of $100 \mathrm{rpm} .100 \mathrm{ml}$ artificial enteric juice with a $\mathrm{pH}$ of $6.8( \pm 0.05)$ at $37^{\circ} \mathrm{C}\left( \pm 0.5^{\circ} \mathrm{C}\right)$ was used. The concentration of GEM was determined spectrophotometrically at $276 \mathrm{~nm}$ (Unicam UV/vis spectrophotometer). The dissolution experiments were conducted in triplicate.

The statistical test ANOVA was used to compare the results of dissolution data. The difference between samples was deemed statistically significant if the $95 \%$ confidence intervals for the means did not overlap $(p<0.05)$.

The effect of D1216 on living cells was tested by using the human colon carcinoma cell line $\mathrm{CaCo}-2$ (ATCC, USA), a model of the intestinal epithelium (Breemen and Li, 2005). Cells were grown in Eagle's minimal essential medium (MEM, Invitrogen) supplemented with $15 \%$ foetal bovine serum (Lonza, Switzerland) and 1\% Na-pyruvate (Sigma, Hungary). Confluent monolayers were obtained in 96-well plates (Orange Scientific, Belgium) 3 days after cell seeding. For toxicity experiments, Dulbecco's Modified Eagle's medium (DMEM) without phenol red was used as assay medium. Two different cytotoxicity tests were performed. The lactate dehydrogenase (LDH) assay detects cell damage and death by measuring the release of the cytoplasmic enzyme LDH from cells due to plasma membrane disruption. The LDH levels in culture medium were determined with a commercially available kit (Cytotoxicity Detection Kit LDH, Roche, Switzerland). An increase in the number of dead or membranedamaged cells results in an increase in LDH activity in the cell-free culture supernatant. Cytotoxicity was calculated as a percentage of the total LDH release from cells treated with $1 \%$ Triton X-100 as detergent. The MTT test measures cell viability, because only living and metabolically active cells can convert the yellow tetrazolium salt (MTT, Sigma M5655) into insoluble purple formazan crystals. The extent of dye conversion was determined spectrophotometrically by measuring the absorbance at $570 \mathrm{~nm}$. In the MTT assay, a

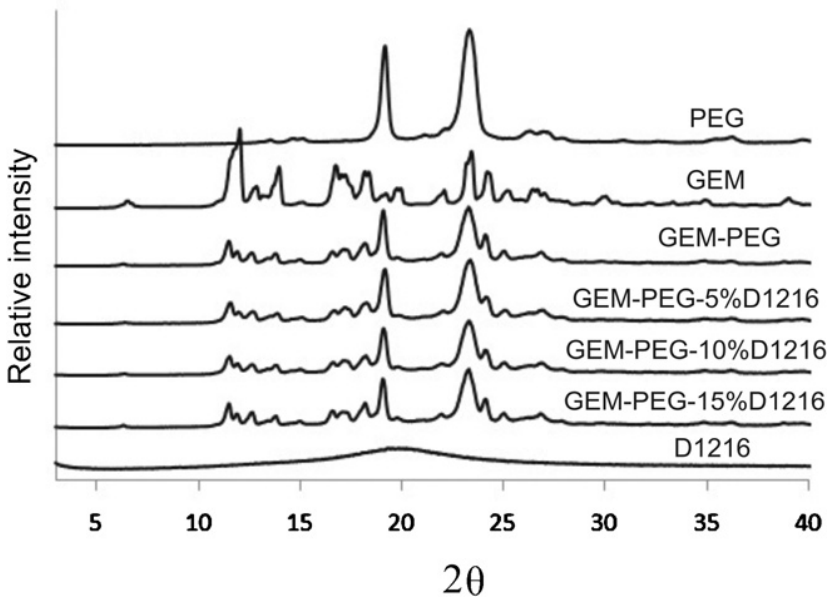

Fig. 1. X-ray power diffraction data of pure materials and solid dispersion systems.

decrease in dye reduction correlates to the cell damage. Viability was calculated as a percentage of the number of untreated control cells. All experiments were repeated at least three times; the number of parallel wells for each treatment and time point varied between 4 and 8 .

An earlier study revealed that the hydrophilic sucrose stearate and sucrose palmitate do not melt during heating, but only soften (Szüts et al., 2007). In consequence of this thermal behaviour, the distribution of a drug in their melts is difficult, and can result in an inhomogeneous product. Hence, in the present study, the applicability of sucrose laurate as a surfactant was examined in a third-generation solid dispersion system. The solid dispersions were prepared by the melting method, containing GEM as model drug and PEG 6000 as carrier, with or without D1216 as surfactant. In the ternary solid dispersion systems, when D1216 was used up to $15 \%$, a homogeneous melt could be formed.

Intact GEM and PEG 6000 displayed identical sharp XRPD peaks at various values of $2 \theta$, while the X-ray pattern of D1216 exhibited an amorphous, broad halo (Fig. 1). In order to determine the crystallinity degree of drug in solid dispersions, the intensity of the most characteristic peak of GEM (intensity: 7767 at $2 \theta=12.06$ ) was evaluated in the various systems. The XRPD pattern of GEM binary solid dispersions demonstrated the diffraction peak of the crystalline drug. This suggested that GEM existed in the crystalline state in the solid dispersion system. However, the intensity of the peaks of crystalline GEM in the solid dispersions was significantly lower than that of the intact drug, indicating a lower degree of crystallinity of GEM in the binary solid dispersion system (inten-

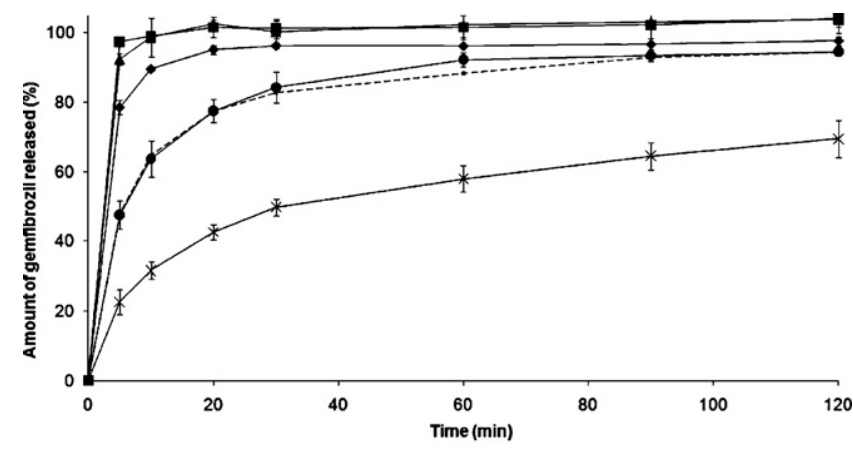

*GEM - - GEM-PEG $\quad$-GEM-PEG-1\%D1216 -GEM-PEG-10\%D1216 —GEM-PEG-15\%D1216

Fig. 2. Dissolution curves of GEM and solid dispersion systems containing various concentrations $(0,1,5,10$ and $15 \%)$ of D1216 as surfactant. 
$\mathrm{LDH}$ release (lh)

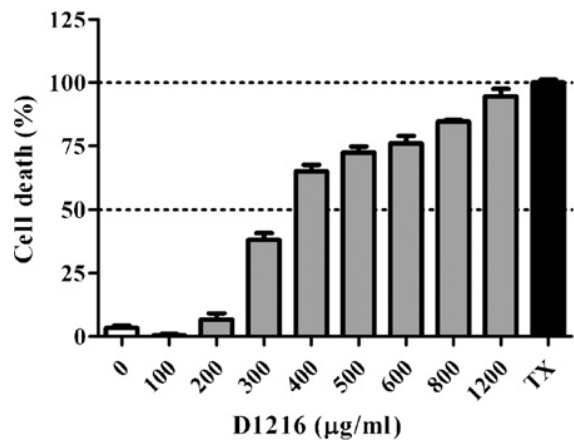

MTT conversion (4h)

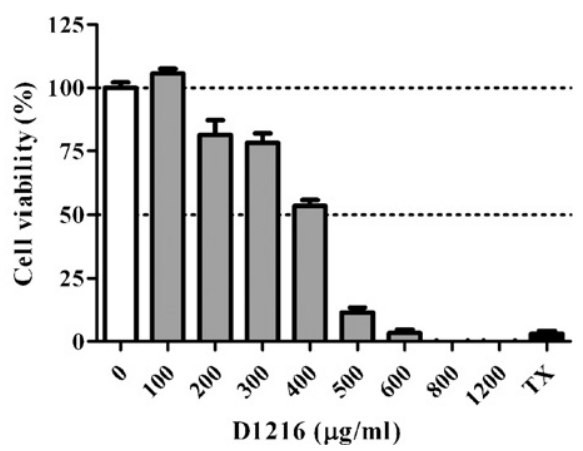

Fig. 3. Cytotoxicity measurements on various concentrations of D1216 on Caco-2 epithelial cells by LDH release after treatment for $1 \mathrm{~h}$ with D1216, and MTT dye conversion following treatment for $4 \mathrm{~h}$ (means $\pm \mathrm{SD}, n=8-4$ ).

sity: 2500 at $2 \theta=11.52$ ). As the drug was highly loaded into the solid dispersion, some of the GEM molecules were molecularly dispersed, and a higher amount of GEM existed in the crystalline state. The XRPD patterns of the ternary solid dispersions were similar to those of the binary system (intensities of the most characteristic peak of ternary systems: 2070 at $2 \theta=11.64$ (GEM-PEG-D1216 4055-5), 1950 at $2 \theta=11.56$ (GEM-PEG-D1216 40-50-10) and 2452 at $2 \theta=11.52$ (GEM-PEG-D1216 40-45-15) (Fig. 1). The incorporation of D1216 up to $15 \%$ had no effect on the XRPD pattern of GEM in the solid dispersion system.

Fig. 2 illustrates that the D1216 in samples resulted in significantly higher GEM release than that of started GEM. For the $1 \%$ D1216-containing solid dispersion, the drug release was similar $(p>0.05)$ that to form the binary solid dispersion system, whereas $5 \%$ SE resulted in significantly faster release. In this case, $90 \%$ of the GEM had dissolved after $10 \mathrm{~min}$. With increasing content of D1216, the dissolution rate increased further. 100\% GEM release could be attained after $10 \mathrm{~min}$ on the use of $10 \%$ D1216 (Fig. 2). Increase of the D1216 concentration from $10 \%$ to $15 \%$ did not result in significantly faster release. Accordingly, 5-10\% D1216 seems to be optimum for solid dispersions of GEM.

PEGs have been used extensively as carriers for solid dispersions due to their favourable solution properties, low melting points and low toxicity. Thanks to these characteristics, they are approved by the FDA for internal consumption.

Besides improving dissolution, surfactants can also enhance absorption, thereby increasing the bioavailibility of poorly soluble drugs (Deli, 2009). However, surfactants may be cytotoxic, which can reduce their applicability in oral formulations (Dimitrijevic et al., 2000; Ekelund et al., 2005; Kiss et al., 2010). In this study, therefore, cytotoxicity measurements were made on the human intestinal epithelial cell line Caco-2 in order to determine the maximum non-toxic concentration of D1216 as absorption enhancer. The cytotoxicity of various concentrations of D1216 in LDH tests is shown in Fig. 3. The concentration of D1216 that caused no toxicity after $1 \mathrm{~h}$ was below $200 \mu \mathrm{g} / \mathrm{ml}$. In the MTT studies, the duration of treatment was $4 \mathrm{~h}$, and significant toxicity was observed when the D1216 concentration exceeded $100 \mu \mathrm{g} / \mathrm{ml}$ (Fig. 3). Above $600 \mu \mathrm{g} / \mathrm{ml} \mathrm{D} 1216$, high toxicity occurred, resulting in the death of Caco-2 cells (Fig. 3 ).

Our dissolution studies shown, that applying 5-10\% D1216 was optimum for GEM solid dispersions. In these formulations, the concentrations of D1216 in the dissolution media were $83.3 \mu \mathrm{g} / \mathrm{ml}$ (5\% D1216) and $166.7 \mu \mathrm{g} / \mathrm{ml}$ (10\% D1216), proved to be non-toxic towards Caco-2 cells.

The cytotoxicity studies demonstrated similarly as with other surfactants, that, when the internal applicability of sucrose laurate is under consideration, the possible risk of the local effect of an increased concentration in the microenvironment of the gastrointestinal tract must be taken into account. It should be noted that the SEs are widely used in different food products, and their acceptable daily intake was set as $40 \mathrm{mg} / \mathrm{kg} / \mathrm{day}$. Sucrose laurate was not considered in that evaluation, but the European Food Safety Authority (EFSA) recently pointed out that the current specifications should be changed to include sucrose laurate (EFSA, 2010).

It can be concluded that the applicability of sucrose laurate in third-generation solid dispersions prepared by melt technology may be regarded as a good technique with which to accelerate the dissolution of poorly soluble drugs such as GEM. The presence of $1-15 \%$ surface-active agent did not appear to affect the solid-state characteristics of GEM significantly. The in vitro dissolution studies shown, that applying 5-10\% D1216 was optimum to improve GEM release from solid dispersions. In these formulations, the concentrations of sucrose laurate in the dissolution media were $83.3 \mu \mathrm{g} / \mathrm{ml}$ (5\% D1216) and $166.7 \mu \mathrm{g} / \mathrm{ml}(10 \% \mathrm{D} 1216)$, proved to be non-toxic towards Caco- 2 cells.

\section{Acknowledgement}

This work was supported by TÁMOP research project: Development of teranostics in cardiovascular, metabolics, and inflammatory diseases (TÁMOP-4.2.2-08/1-2008-0013).

\section{References}

Abd-Elbary, A., El-laithy, H.M., Tadros, M.I., 2008. Sucrose stearate-based proniosome derived niosomes for the nebulisable delivery of cromolyn sodium. Int. J. Pharm. 357, 189-198.

Bikiaris, D., Papageorgiou, G.Z., Stergiou, A., Pavlidou, E., Karavas, E., Kanaze, F., Georgarakis, M., 2005. Physicochemical studies on solid dispersions of poorly water-soluble drugs. Evaluation of capabilities and limitations of thermal analysis techniques. Thermochim. Acta 439, 58-67.

Breemen, R.B., Li, Y., 2005. Caco-2 permeability assays to measure drug absorption. Expert Opin. Drug Metab. Toxicol. 1, 175-185.

Craig, D.Q.M., Newton, J.M., 1991. Characterisation of polyethylene glycol solid dispersions using differential scanning calorimetry and solution calorimetry. Int. J. Pharm. 76, 17-24.

Csóka, G., Marton, S., Zelko, R., Otomo, N., Antal, I., 2007. Application of sucrose fatty acid esters in transdermal therapeutic systems. Eur. J. Pharm. Biopharm. 65, 233-237.

Dehghan, M.H.G., Jafar, M., 2006. Improving dissolution of meloxicam using solid dispersions. Iran. J. Pharm. Res. 4, 231-238.

Deli, M.A., 2009. Potential use of tight junction modulators to reversibly open membranous barriers and improve drug delivery. Biochim. Biophys. Acta 1788, 892-910.

Dimitrijevic, D., Shaw, A.J., Florence, A.T., 2000. Effects of some non-ionic surfactants on transepithelial permeability in Caco-2 cells. J. Pharm. Pharmacol. 52, 157-162.

EFSA Panel on Food Additives Nutrient Sources added to Food (ANS), 2010. Scientific opinion on the safety of sucrose esters of fatty acids prepared from vinyl esters of fatty acids and on the extension of use of sucrose esters of fatty acids in flavourings. EFSA J. 8, 1512. 
Ekelund, K., Osth, K. Påhlstorp, C. Björk, E. Ulvenlund, S., Johansson, F., 2005. Correlation between epithelial toxicity and surfactant structure as derived from the effects of polyethyleneoxide surfactants on caco-2 cell monolayers and pig nasal mucosa. J. Pharm. Sci. 94, 730-744.

Ganem Quintanar, A., Quintanar-Guerrero, D., Falson-Rieg, F., Buri, P., 1998. Ex vivo oral mucosal permeation of lidocaine hydrochloride with sucrose fatty acid esters as absorption enhancers. Int. J. Pharm. 173, 203-210.

Jagdale, S.C., Kuchekar, B.S., Chabukswar, A.R., Musale, V.P., Jadhao, M.A., 2010 Preparation and in vitro evaluation of Allopurinol-Gelucire 50/13 solid dispersions. Int. J. Adv. Pharm. Sci. 1, 60-67.

Kiss, T., Fenyvesi, F., Bácskay, I., Váradi, J., Fenyvesi, E., Iványi, R., Szente, L., Tósaki, A., Vecsernyés, M., 2010. Evaluation of cytotoxicity of $\beta$-cyclodextrin derivatives: evidence for the role of cholesterol extraction. Eur. J. Pharm. Sci. 40, 376-380.

Leuner, C., Dressman, J., 2000. Improving drug solubility for oral delivery using solid dispersions. Eur. J. Pharm. Biopharm. 50, 47-60.

Liu, L., Wang, X., 2007. Improved Dissolution of Oleanolic Acid with Ternary Solid Dispersions. AAPS PharmSciTech. 8, Article 113.

Mura, P., Faucci, M.T., Manderioli, A., Bramanti, G., Parrini, P., 1999. Thermal behavior and dissolution properties of naproxen from binary and ternary solid dispersions. Drug Dev. Ind. Pharm. 25, 257-264.

Ntawukulilyayo, J.D., Bouckaert, S., Remon, J.P., 1993. Enhancement of dissolution rate of nifedipine using sucrose ester coprecipitates. Int. J. Pharm. 93, 209-214

Okamoto, H., Takashi, S., Kazumi, D., 2005. Effect of sucrose fatty acid esters on transdermal permeation of lidocaine and ketoprofen. Biol. Pharm. Bull. 28 1689-1694.

Okonogi, S., Puttipipatkhachorn, S., 2006. Dissolution Improvement of High Drugloaded Solid Dispersion. AAPS PharmSciTech. 7, Article 52.

Otomo, N., 2009. Basic properties of sucrose fatty acid esters and their applications. In: Hayes, D.G., Kitamoto, D., Solaiman, D.K.Y., Ashby, R.D. (Eds.), Biobased Surfactants and Detergents: Synthesis, Properties, and Applications. AOCS Press, Urbana, Illinois, pp. 275-298.
Owusu-Ababio, G., Ebube, N.K., Reams, R., Habib, M., 1998. Comparative dissolution studies for mefenamic acid-polyethylene glycol solid dispersion systems and tablets. Pharm. Dev. Technol. 3, 405-412.

Saharan, V.A., Kukkar, V., Kataria, M., Gera, M., Choudhury, P.K., 2009. Dissolution enhancement of drugs. Part I: Technologies and effect of carriers. Int. J. Health Res. 2, 107-124.

Serajuddin, A.T.M., 1999. Solid dispersion of poorly water-soluble drugs: early promises subsequent problems, and recent breakthroughs. J. Pharm. Sci. 88 1058-1066.

Sethia, S., Squillante, E., 2002. Physicochemical characterization of solid dispersions of carbamazepine formulated by supercritical carbon dioxide and conventional solvent evaporation method. J. Pharm. Sci. 91, 1948-1957.

Shibata, D., Shimada, Y., Yonezawa, Y., Sunada, H., Otomo, N., Kasahara, K., 2002. Application and evaluation of sucrose fatty acid esters as lubricants in the production of pharmaceuticals. J. Pharm. Sci. Technol. 62, 133145.

Szűts, A., Pallagi, E., Regdon, G., Aigner, Z., Szabó-Révész, P., 2007. Study of thermal behaviour of sugar esters. Int. J. Pharm. 336, 199-207.

Szüts, A., Makai, Zs., Rajkó, R., Szabó-Révész, P., 2008. Study of the effects of drugs on the structures of sucrose esters and the effects of solid-state interactions on drug release. J. Pharm. Biomed. Anal. 48, 1136-1142.

Szüts, A., Budai-Szücs, M., Erős, I., Otomo, N., Szabó-Révész, P., 2010a. Study of gelforming properties of sucrose esters for thermosensitive drug delivery systems. Int. J. Pharm. 383, 132-137.

Szüts, A., Budai-Szűcs, M., Erős, I., Ambrus, R., Otomo, N., Szabó-Révész, P., 2010b. Study of thermo-sensitive gel-forming properties of sucrose stearates. J. Excipients Food Chem. 1, 13-20.

Vasconcelos, T., Sarmento, B. Costa, P. 2007. Solid dispersions as strategy to improve oral bioavailability of poor water soluble drugs. Drug Discov. Today 12, 1068-1075. 
PUBLICATION II. 


\title{
RAPID COMMUNICATION
}

\section{Kinetic Analysis of the Toxicity of Pharmaceutical Excipients Cremophor EL and RH40 on Endothelial and Epithelial Cells}

\author{
LÓRÁND KISS, ${ }^{1,2}$ FRUZSINA R. WALTER, ${ }^{1}$ ALEXANDRA BOCSIK, ${ }^{1,2}$ SZILVIA VESZELKA, ${ }^{1}$ BÉLA ÓZSVÁRI, ${ }^{3}$ LÁSZLÓ G. PUSKÁS, ${ }^{3}$ \\ PIROSKA SZABÓ-RÉVÉSZ, ${ }^{2}$ MÁRIA A. DELI ${ }^{1}$ \\ ${ }^{1}$ Laboratory of Molecular Neurobiology, Institute of Biophysics, Biological Research Centre of the Hungarian Academy of Sciences, \\ Szeged H-6726, Hungary \\ ${ }^{2}$ Department of Pharmaceutical Technology, University of Szeged, Szeged H-6720, Hungary \\ ${ }^{3}$ Avidin Ltd., Szeged H-6726, Hungary
}

Received 16 July 2012; revised 4 December 2012; accepted 4 January 2013

Published online 29 January 2013 in Wiley Online Library (wileyonlinelibrary.com). DOI 10.1002/jps.23458

\begin{abstract}
Cremophor EL and RH40 are widely used excipients in oral and intravenous drug formulations such as Taxol infusion to improve drug dissolution and absorption. Studies indicate that Cremophors, especially EL, have toxic side effects, but few data are available on endothelial and epithelial cells, which form biological barriers and are directly exposed to these molecules. Human hCMEC/D3 brain endothelial and Caco-2 epithelial cells were treated with Cremophor EL and RH40 in the $0.1-50 \mathrm{mg} / \mathrm{mL}$ concentration range. Cell toxicity was monitored by real-time cell microelectronic sensing and verified by lactate dehydrogenase release and 3(4,5-dimethylthiazol-2-yl)-2,5-diphenyltetrazolium bromide (MTT) assays, and morphological methods. Cremophors caused dose- and time-dependent damage in both cell types. In endothelial cells, $0.1 \mathrm{mg} / \mathrm{mL}$ and higher concentrations, in epithelial cells, concentrations of $5 \mathrm{mg} / \mathrm{mL}$ and above were toxic, especially at longer incubations. Cell death was also proven by double fluorescent staining of cell nuclei. Immunostaining for tight junction proteins claudin- 4 and -5 showed barrier disruption in cells treated by surfactants at $24 \mathrm{~h}$. In conclusion, Cremophor EL and RH40 in concentrations corresponding to clinical doses caused endothelial and epithelial toxicity. Endothelial cells were more sensitive to surfactant treatment than epithelial cells, and Cremophor EL was more toxic than RH40 in both cell types. (C) 2013 Wiley Periodicals, Inc. and the American Pharmacists Association J Pharm Sci 102:1173-1181, 2013

Keywords: absorption enhancer; Caco-2 cells; cell toxicity; Cremophor; endothelial; epithelial; excipient; real-time cell microelectric sensing; surfactant; toxicokinetics
\end{abstract}

\section{INTRODUCTION}

Excipients are necessary for effective drug dissolution of pharmacons and their transport across biological barriers. ${ }^{1}$ Nonionic surfactants such as Tweens and Cremophor EL and RH40 are widely employed to improve dissolution and delivery of drugs. ${ }^{2}$ Their toxicity profile is better than that of ionic surfactants, ${ }^{3}$ still during their application, side effects often occur. Cremophor EL and RH40 are polyoxyethylene castor oil derivatives used to formulate several drugs such as antineoplastic paclitaxel, teniposide, and aplidine;

Correspondence to: Mária A. Deli (Telephone: +36-62-599602; Fax: +36-62-433133; E-mail: deli.maria@brc.mta.hu)

Journal of Pharmaceutical Sciences, Vol. 102, 1173-1181 (2013)

() 2013 Wiley Periodicals, Inc. and the American Pharmacists Association immunomodulatory cyclosporine A; sedative diazepam; and antiretroviral lopinavir and ritonavir. ${ }^{2,4}$

Cremophor EL is applied in infusions, such as Taxol, in oral capsules, such as Gengraf, as well as in solutions. ${ }^{2}$ Adverse effects observed for Cremophor $\mathrm{EL}^{4}$ include anaphylactoid hypersensitivity reactions due to complement activation in human plasma. ${ }^{5} \mathrm{Ax}-$ onal demyelination ${ }^{6}$ and acute toxicity of the heart and thymocytes ${ }^{7,8}$ were found in rats. Cremophor EL induced damage in isolated human cancer cells ${ }^{9}$ and human cell lines including Caco-2. ${ }^{10}$ These toxic effects are related to inhibition of cardiac mitochondrial respiration, ${ }^{11}$ cell membrane perturbation, ${ }^{4,12}$ and promotion of oxidative stress. ${ }^{8,13}$

Cremophor RH40 is used in microemulsions, ${ }^{14}$ in self-emulsifying drug delivery systems, ${ }^{15}$ in buccoadhesive tablets, ${ }^{16}$ and in oral formulations, such as 
Neoral (Novartis, East Hanover, NJ). Recently, our group has used Cremophor RH40 as an absorption enhancer in a nasal drug delivery system. ${ }^{17}$ Cremophor RH40 is intensely investigated as a pharmaceutical excipient, but there is little data on its toxicity profile in cultured cells. ${ }^{18,19}$

Despite the use of Cremophors in clinically applied drugs and in other formulations, their toxicity on biological barriers is not fully understood. To our knowledge, there is no published information about the effect of Cremophors on brain endothelial cells, which are directly affected during infusions of drugs and may be related to their side effects.

The aim of the study was to evaluate the toxic effects of Cremophor EL and RH40 on culture models of two important biological barriers. Brain endothelial cells, applied in blood-brain barrier studies, ${ }^{20,21}$ and Caco-2 human intestinal epithelial cells, a model of small intestinal barrier, ${ }^{22}$ were tested with Cremophors in clinically relevant doses by real-time cell microelectronic sensing (RT-CES), a new label-free method, colorimetric end-point viability assays, and cell morphology.

\section{MATERIALS AND METHODS}

\section{Chemicals}

All reagents were purchased from Sigma-Aldrich Ltd., Budapest, Hungary, unless otherwise indicated.

\section{Cell Culture}

Human cell lines brain microvascular endothelial hCMEC/D3 cells, ${ }^{23}$ intestinal epithelial Caco-2 cells (ATCC HTB-37), and primary rat brain endothelial cells were used. D3 cells were grown in Endothelial Basal Medium-2 (EBM-2) containing Endothelial Growth Medium-2 (EGM-2) BulletKit (Lonza, Basel, Switzerland) supplemented with $2.5 \%$ fetal bovine serum in a humidified $37^{\circ} \mathrm{C}$ incubator with $5 \% \mathrm{CO}_{2}$. Caco-2 cells were grown in Eagle's minimal essential medium (Gibco, Invitrogen, Budapest, Hungary and Carlsbad, CA) supplemented with $10 \%$ fetal bovine serum, $1 \%$ sodium-pyruvate, and $50 \mu \mathrm{g} / \mathrm{mL}$ gentamicin. Primary cultures of cerebral endothelial cells were prepared from 2 -week-old rats $^{24}$ and used for morphological studies. Cell lines were seeded in culture dishes at a density of $5 \times 10^{4} \mathrm{cells} / \mathrm{cm}^{2}$, and the medium was changed every 2 days. Cells were subcultured with $0.05 \%$ trypsin-EDTA solution. For RTCES, 96-well E-plates with built-in gold electrodes (Roche, Budaörs, Hungary and Basel, Switzerland) were used. Surfaces were coated with $0.05 \%$ rat-tail collagen before cell seeding.

\section{Treatment}

Cremophor EL and RH40 (pharmaceutical grade; BASF, Lampertheim, Germany) were tested at $0.1-50 \mathrm{mg} / \mathrm{mL}$ concentrations. Triton X-100 detergent $(10 \mathrm{mg} / \mathrm{mL})$ was used in toxicity assays as a reference compound to cause cell death.

\section{Real-Time Cell Microelectronic Sensing}

This technique dynamically monitors living cells. ${ }^{25,26}$ The xCELLigence system (Roche) utilizes impedance derived from interaction between cells and electrodes of E-plates to noninvasively quantify cell proliferation and viability in real time. Culture medium $(80 \mu \mathrm{L})$ was added to each well for background readings, then $80 \mu \mathrm{L}$ cell suspension was dispensed at the density of $1 \times 10^{4}$ cells/well. Cells were grown until confluency. Impedance was measured every 2 min following treatments. The cell index $(\mathrm{CI})$ at each time point was defined as $\left(R_{\mathrm{n}}-R_{\mathrm{b}}\right) / 15$, where $R_{\mathrm{n}}$ is the cell-electrode impedance of the well when it contains cells, and $R_{\mathrm{b}}$ is the background impedance of the well with the medium alone. The CIs were normalized to the latest time point before the treatment of each group $\left(\mathrm{CI}_{n} /\right.$ $\mathrm{CI}_{\text {before treatment }}$ ) or presented as percent of nontreated control group $\left[\left(\mathrm{CI}_{n} / \mathrm{CI}_{\text {average of control group }}\right) \times 100\right]$. CI values reflect cell number, adherence, cell growth, and health. ${ }^{25,26}$

\section{3-(4,5-Dimethylthiazol-2-yl)-2,5-Diphenyltetrazolium Bromide Dye Reduction and Lactate Dehydrogenase Release Assays}

Colorimetric cell viability assays were performed as described above. ${ }^{27}$ The yellow 3-(4,5-dimethylthiazol2-yl)-2,5-diphenyltetrazolium bromide (MTT) dye is converted by viable cells to purple formazan crystals; therefore, decrease in dye conversion reflects cellular damage. Human endothelial hCMEC/D3 and Caco2 epithelial cells were seeded on 96 -well plates. The confluent monolayers were treated with Cremophors for 1 and $24 \mathrm{~h}$. After treatment, cells were washed with phosphate buffered saline (PBS) solution and incubated with $0.5 \mathrm{mg} / \mathrm{mL}$ MTT solution in Dulbecco's modified Eagle's medium for $3 \mathrm{~h}$. Crystals were diluted with dimethyl sulfoxide, and dye conversion was determined by absorbance measurement at $570 \mathrm{~nm}$. Nontreated control group was considered as $100 \%$ viable.

Cell death and membrane damage were investigated by detecting the release of intracellular lactate dehydrogenase ( $\mathrm{LDH}$ ) enzyme to the phenol-red-free culture medium. Cells in 96-well plates were treated by Cremophors for 1 and $24 \mathrm{~h}$. The LDH levels in culture supernatants were determined by a kit (Cytotoxicity Detection Kit LDH; Roche). Cytotoxicity was calculated as a percentage of the total $\mathrm{LDH}$ release from cells treated with $1 \%$ Triton X-100 detergent. 


\section{Fluorescent Stainings}

Cell viability was determined by double fluorescent staining: bis-benzimide (Hoechst 33342 dye) labels all cell nuclei, ethidium-homodimer-1 (Molecular Probes, Eugene, OR) stains only dead cells. For morphological examinations, primary brain endothelial cells with tight barrier properties ${ }^{24}$ were used. Cells grown on glass coverslips were treated with Cremophor EL and RH40 for 1 and $24 \mathrm{~h}$. Thirty minutes before the end of the treatment, $10 \mu \mathrm{M}$ bis-benzimide and ethidium-homodimer-1 were added to the cells. Cells were fixed in $4 \%$ paraformaldehyde in PBS, permeabilized with $0.2 \%$ Triton X-100, and blocked with $3 \%$ bovine serum albumin-PBS. Endothelial cells were incubated with anti-claudin-5 antibody, and epithelial cells were treated with claudin-4 antibody (Invitrogen) overnight. Incubation with Alexa-488 -labeled secondary anti-rabbit antibody (Invitrogen) lasted for $1 \mathrm{~h}$. Cells were washed three times with PBS between each step. Coverslips were mounted in Gel Mount (Biomeda, Foster City, CA). Claudin-5 stainings were examined by a NikonEclipse TE2000 fluorescent microscope (Nikon, Tokyo, Japan) and photographed by a Spot RT digital camera (Diagnostic Instruments, Sterling Heights, MI). The claudin-4 immunostaining of epithelial cells was detected by Leica SP5 confocal microscope (Leica Microsystems CMS GmbH, Mannheim, Germany).

\section{Statistical Analysis}

All data presented are means \pm SD. Values were compared using analysis of variance followed by Dunnett's test (GraphPad Prism 5.0; GraphPad Software Inc., San Diego, CA). Changes were considered statistically significant at a $p$ value of less than 0.05 . All experiments were repeated at least two times; the number of parallel samples varied between four and 12 .

\section{RESULTS}

The toxicokinetic effects of Cremophors were tested on endothelial and intestinal epithelial cells by RTCES. In the experiments, cell damage was specified as normalized CI, below the value of 0.5. In hCMEC/D3 endothelial cells, both Cremophors showed dose- and time-dependent toxicity. At 1-h after treatment, no differences were observed as compared with control. Statistically significant decrease was seen in CI values at the concentrations of $10 \mathrm{mg} / \mathrm{mL}(p<0.05)$ and $50 \mathrm{mg} / \mathrm{mL}(p<0.001)$ from $2 \mathrm{~h}$ (Figs. 1a and 1b). Cremophors at all concentrations $(0.1-5 \mathrm{mg} / \mathrm{mL})$ resulted in impedance drop in human endothelial cells. Concentrations of $5 \mathrm{mg} / \mathrm{mL}$ and above caused cell damage after $2-3 \mathrm{~h}$ and cell death similar to the toxicity control after $12 \mathrm{~h}$.
In Caco-2 epithelial cells treatment with $1 \mathrm{mg} / \mathrm{mL}$, Cremophors caused no decrease in CI compared with control, indicating no cell damage (Figs. 1c and 1d). In the first $10 \mathrm{~h}$, Cremophor EL at $5 \mathrm{mg} / \mathrm{mL}$ increased the impedance, then decreased it, and after $20 \mathrm{~h}$ of treatment, epithelial cell death was detected. At 10-50 mg/ $\mathrm{mL}$ doses of the surfactant, rapid increase of the CI was observed, followed by a drop of impedance and total loss of cell viability after $12 \mathrm{~h}$. The kinetics of the CI in epithelial cells treated with Cremophor RH40 was similar to Cremophor EL, but the impedance drop and cell death were delayed (Fig. 1d).

The results of RT-CES measurement at 24-h treatment point is shown in Figure 2. In endothelial cells, both excipients significantly decreased the impedance at all concentrations (Figs. 2a and 2b). The smallest $0.1 \mathrm{mg} / \mathrm{mL}$ concentration significantly reduced ( $p<$ 0.001), whereas higher doses drastically lowered the CI of hCMEC/D3 cells, reflecting cell death.

In contrast, the two smallest concentrations of the tensids caused no damage in Caco-2 cells even after 24-h treatment (Figs. 2c and 2d). The effects of the two surfactants differed at the doses of $5-10 \mathrm{mg} / \mathrm{mL}$. Cremophor RH40 caused lower toxicity than EL. At the highest concentration, Cremophors exerted cell death in epithelial cells similarly to endothelial cells.

The real-time measurements were verified by colorimetric assays (Fig. 3). Endothelial cells were viable, and no membrane leakage was detected at 1$\mathrm{h}$ application of surfactants (Fig. 3a). Cremophors at $5-50 \mathrm{mg} / \mathrm{mL}$ doses increased cell viability. The presence of excipients for $24 \mathrm{~h}$ did not cause cell damage below $1 \mathrm{mg} / \mathrm{mL}$ doses, whereas $5 \mathrm{mg} / \mathrm{mL}$ and higher concentrations killed the endothelial cells (Fig. 3b). Caco-2 cells treated with Cremophors for $1 \mathrm{~h}$ did not show decrease of viability by MTT or membrane damage by LDH assays (Fig. 3c). One day treatment with 10 and $50 \mathrm{mg} / \mathrm{mL}$ surfactants increased the leakage of $\mathrm{LDH}$ enzyme to cell supernatant (Fig. 3d). Cell viability of epithelial cells measured by MTT was only affected by $50 \mathrm{mg} / \mathrm{mL}$ Cremophors. Significant differences were observed between the effects of Cremophor EL and RH40 on epithelial cells by end-point assays as well. Cremophor EL decreased cell viability and increased cell toxicity more than RH40. These methods strengthen our observation that brain endothelial cells are more sensitive than intestinal epithelial cells: Cremophors kill endothelial cells at $5 \mathrm{mg} / \mathrm{mL}$ concentration, whereas in Caco-2 cells, $50 \mathrm{mg} / \mathrm{mL}$ doses caused a similar effect.

The toxicity of Cremophors was also examined by fluorescent cell nuclei staining of primary endothelial cells and Caco-2 epithelial cells after 1- and 24-h treatments (Fig. 4). Short treatment with surfactants $(1-50 \mathrm{mg} / \mathrm{mL})$ did not result in endothelial cell death, as demonstrated by the blue cell nuclei, in agreement 

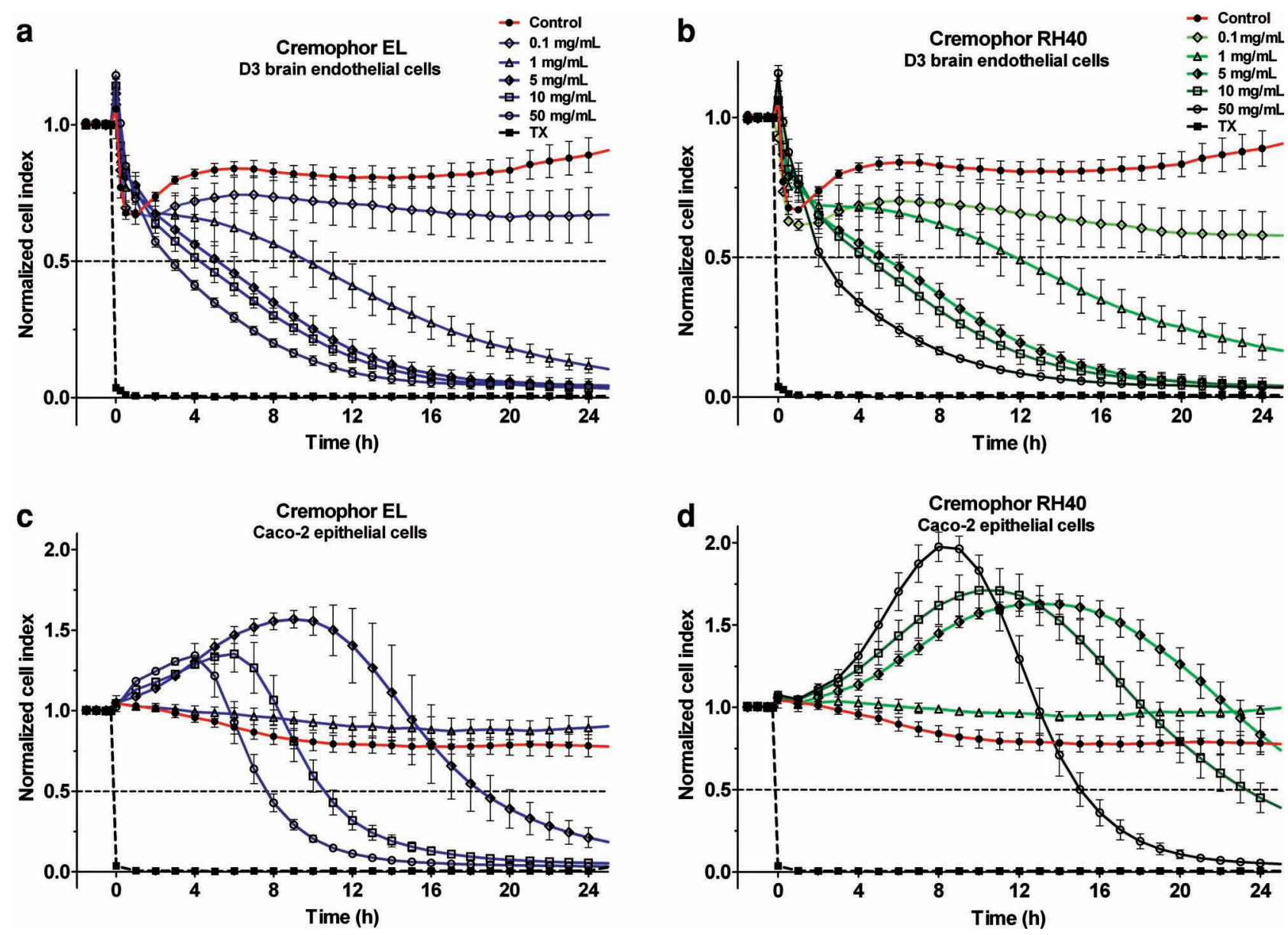

Figure 1. Effects of Cremophor EL and RH40 (0.1-50 mg/mL) on human hCMEC/D3 endothelial ( $\mathrm{a}$ and b) and Caco-2 intestinal epithelial (c and d) cells measured by RT-CES method. CI is expressed as an arbitrary unit and calculated from impedance measurements between cells and sensors. Data are presented as mean $\pm \mathrm{SD}, n=4$. TX, Triton X-100 at $10 \mathrm{mg} / \mathrm{mL}$ dose.

with data in Figures 1 and 3. Treatment with Cremophors from $10 \mathrm{mg} / \mathrm{mL}$ for $24 \mathrm{~h}$ or Triton-X 100 led to red staining of cell nuclei, indicating membrane damage and toxicity (Fig. 4). Immunostaining for claudin5 endothelial tight junction protein was changed by all investigated doses of Cremophors at 1-h incubation. In contrast to control cells, where a typical continuous belt-like staining was seen, holes appeared between cells indicating barrier damage. Uneven pericellular claudin-5 staining with thickening and zipperlike pattern was also observed (Fig. 4). After 24-h, disappearance and disorganization of the junctional staining were observed. Cremophors induced cell detachment and cell death at the highest doses (10 and $50 \mathrm{mg} / \mathrm{mL}$ ).

In Caco-2 epithelial cells, no difference in nucleus staining was noticed after a 1-h treatment with Cremophors (Fig. 4). Changes in claudin-4 staining could already be detected at 1-h treatment; disappearance or weak immunostaining at cell junctions and irregular membrane or cytoplasmic staining patterns were observed (Fig. 4). Incubation for $24 \mathrm{~h}$ with
Cremophors at $1 \mathrm{mg} / \mathrm{mL}$ did not kill epithelial cells, but claudin-4 immunostaining became irregular and its membrane localization became disturbed. Both epithelial viability and monolayer integrity were seriously impaired at $10-50 \mathrm{mg} / \mathrm{mL}$ concentrations at 24-h treatment. Cremophor EL enhanced cell detachment.

\section{DISCUSSION}

The use of Cremophor EL in various dosage forms is accompanied by many adverse reactions. ${ }^{4}$ Understanding the side effects of Cremophor EL is important for safety reasons. The toxicity of Cremophor RH40 is less well known and examined, but it is also important because of its application in oral solutions and soft gelatin capsules. ${ }^{2}$

In our study, the cytotoxicity of Cremophors was investigated in endothelial and epithelial cells using concentrations corresponding to clinically administered doses. Cremophor EL concentrations in blood can reach $5 \mathrm{mg} / \mathrm{mL}$ after infusions of Taxol or 
a
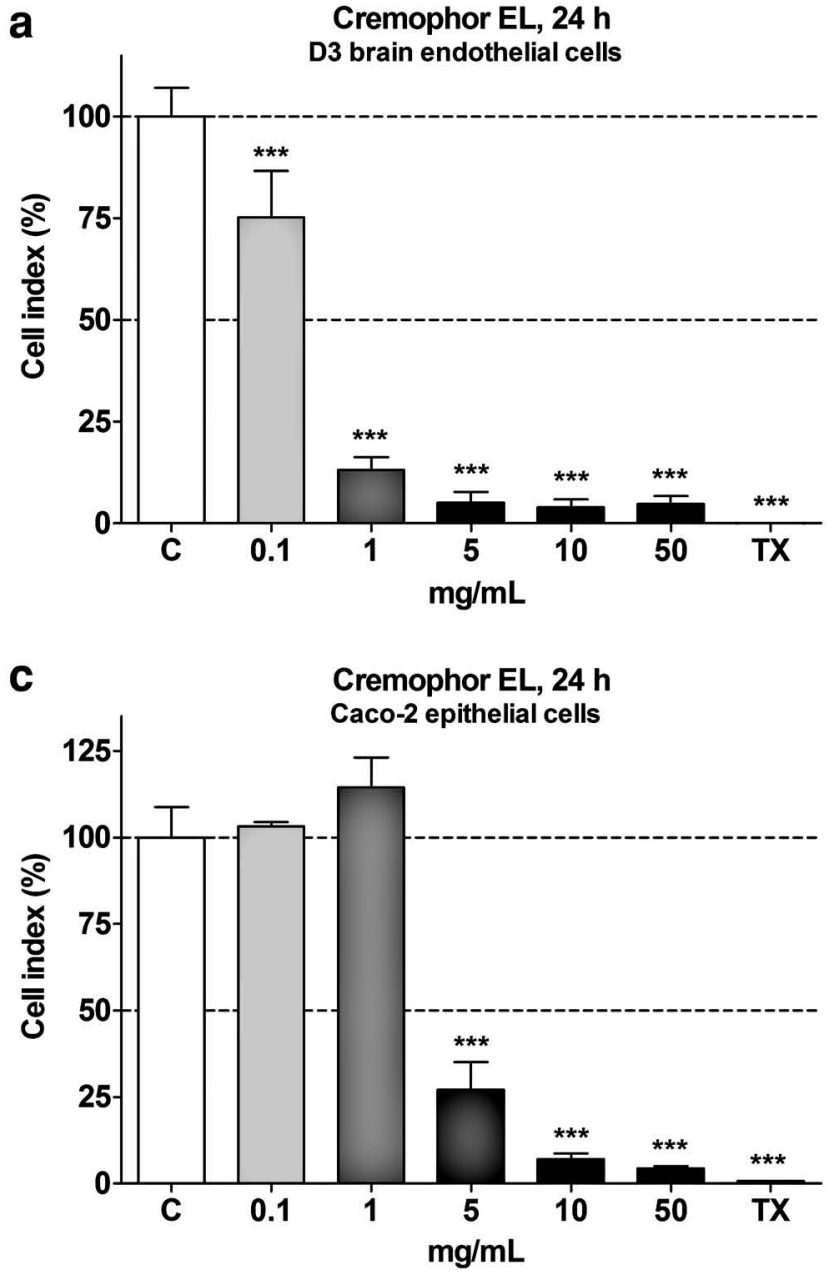
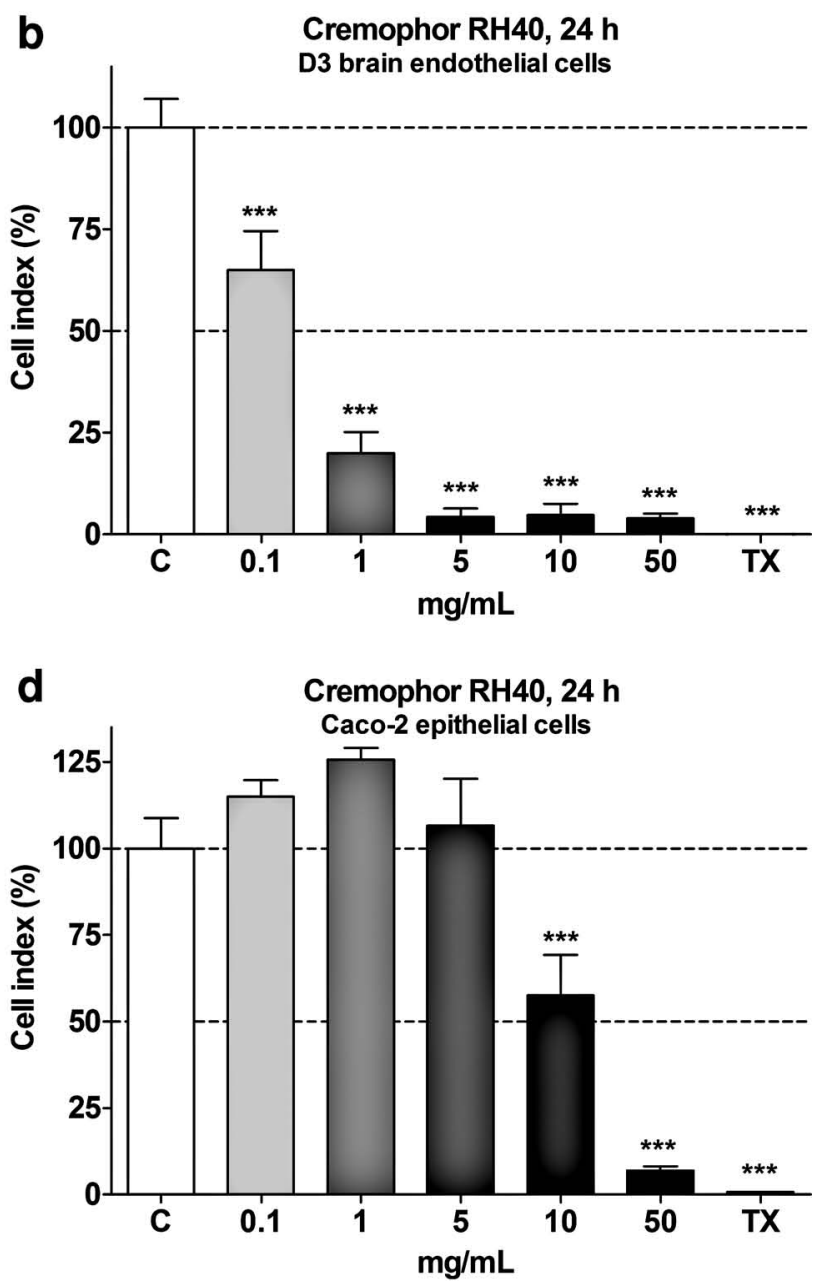

Figure 2. Effects of Cremophor EL and RH40 $(0.1-50 \mathrm{mg} / \mathrm{mL}, 24 \mathrm{~h})$ on human hCMEC/D3 endothelial ( $a$ and $b$ ) and Caco-2 epithelial ( $c$ and d) cells measured by RT-CES method. CI is expressed as an arbitrary unit and calculated from impedance measurements between cells and sensors. Data are presented as mean $\pm \mathrm{SD}, n=4$; statistical analysis: ANOVA followed by Dunnett test; ${ }^{* * *} p<0.001$, all doses were compared with control. C, control; TX, Triton X-100 at $10 \mathrm{mg} / \mathrm{mL}$ dose.

Sandimmun. ${ }^{4}$ This level can be maintained for $3-24 \mathrm{~h}$, depending on the duration of the chemotherapeutic treatment. Endothelial cells lining blood vessels are exposed to high dose of this surfactant. The kinetics of the toxicity of Cremophor EL and RH40 on human endothelial cells was demonstrated for the first time. The clinically observed side effects might be related to changes in the viability and monolayer integrity of endothelial cells exerted by Cremophors.

The dose of Cremophor EL and RH40 in oral formulations ranges from 2 to 600 and 25 to $405 \mathrm{mg}$, respectively. ${ }^{28}$ Neoral is a soft gelatin capsule of cyclosporin A and contains the highest Cremophor $\mathrm{RH} 40$ dose among oral formulations, $450 \mathrm{mg} /$ capsule. The maximal dose of Neoral is $15 \mathrm{mg} / \mathrm{kg}$ body weight/ day in two equal doses; therefore, Cremophor RH40 may reach $4.5 \mathrm{mg} / \mathrm{mL}$ or higher concentrations in the stomach. It should be considered that patients might take Cremophor-containing drugs chronically, for months or years.

Human intestinal epithelial cells were also damaged by the surfactants. These results are in agreement with previous works indicating impairment of viability in Caco-2 cells treated with Cremophors. ${ }^{10,18}$ An unexpected effect was seen in epithelial cells treated with surfactants using RT-CES and MTT dye conversion assay. The CI was transiently increased in higher doses of both excipients. Such a change was also observed in endothelial cells, but it lasted only for $1 \mathrm{~h}$. Activation of different G-protein-coupled receptors in various mammalian cells led to changes in the cell shape and attachment resulting in a transient increase in CI values. ${ }^{26}$ The increased MTT dye conversion may reflect higher metabolic activity or changes in endocytosis of dye and exocytosis of formazan crystals. The effect of Cremophors on G-protein-coupled 

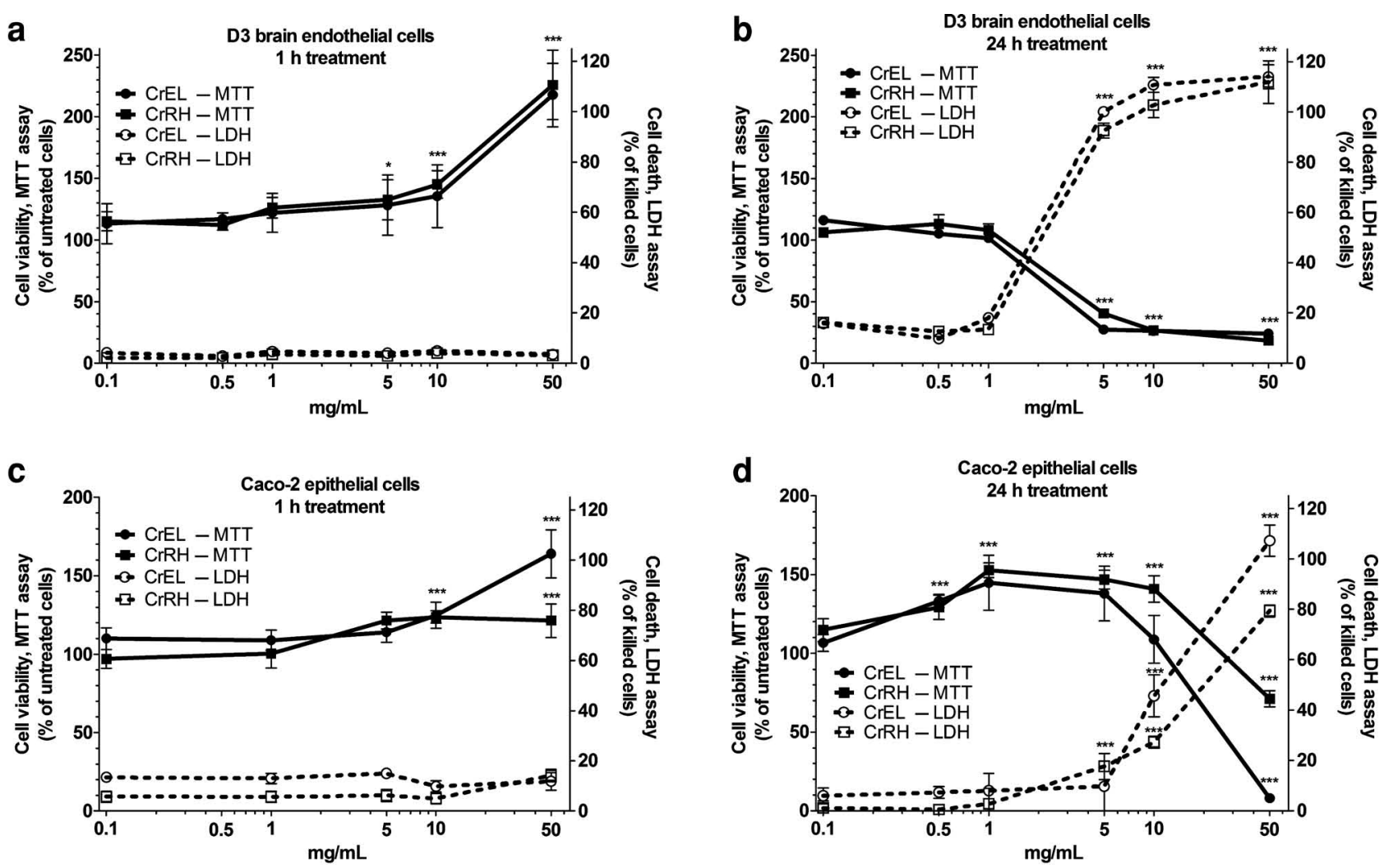

Figure 3. Effects of Cremophor EL and RH40 (0.1-50 mg/mL) on human hCMEC/D3 endothelial cells ( $\mathrm{a}$ and b) and Caco-2 epithelial (c and d) measured by MTT dye conversion and LDH release methods. The MTT values were compared with nontreated group, which was defined as $100 \%$ viable. For LDH measurement, the Triton-X-100-treated group was considered as $100 \%$ dead. Data are presented as mean $\pm \mathrm{SD}, n=5$; statistical analysis: ANOVA followed by Dunnett test; $* p<0.05, * * * p<0.001$, all doses were compared with control. CrEL, Cremophor EL; CrRH, Cremophor RH40.

receptors, metabolic activity, or endocytosis in epithelial or endothelial cells cannot be excluded, and further experiments are needed to reveal this interaction.

Comparing the cell types, endothelial cells were more sensitive than epithelial cells. Short-term incubations with Cremophors resulted in changes only in endothelial cells but not in epithelial cells. Cremophors, similarly to other surfactants, have a profound influence on cell membranes. Depending on concentration, they disturb plasma membranes ${ }^{12}$ or remove certain lipids from the membranes. ${ }^{29}$ Lipid constitution varies between cell types, ${ }^{30}$ thus Caco-2 cell membrane lipid composition ${ }^{31}$ differs from endothelial ones, ${ }^{32}$ and lipid rafts are also dissimilar. ${ }^{30}$ Differences in the membrane lipid composition and in lipid rafts of endothelial and epithelial cells may be related to our observations on the divergent effects of Chremophors on these cell types.

It should be noted that Cremophors modulate efflux transporters including P-glycoprotein. ${ }^{12}$ The Cremophor concentrations used in our study were above the effective concentrations modulating $\mathrm{P}$ glycoprotein ${ }^{12}$ and higher than the critical micellar concentrations ${ }^{33}$; therefore, we assume that the major mode of action of Cremophors may be a direct effect on cell membranes, especially plasma membrane lipids. Our results of LDH release indicate such direct cell membrane damage.

On the basis of the results, Cremophor EL is more toxic than RH40 in cultured endothelial and epithelial cells. Our data are in agreement with the findings on K-562 lymphoid cell line. ${ }^{19}$ The reason of the differences in the toxicity of the Cremophors is unknown. Distinct characteristics in the molecular structures may be related to the observed results. ${ }^{2}$ Cremophor EL contains a double bond not present in Cremophor $\mathrm{RH} 40$. Double bonds are more reactive than single covalent bonds in general, and may result in higher cytotoxic effect. In addition, the hydrophilic-lipophilic balance value of Cremophor EL (12-14) is lower than that of RH40 (14-16). The higher lipophilicity of Cremophor EL may cause higher perturbation in cell membranes. The critical micellar concentration of Cremophor EL is also lower than that of 

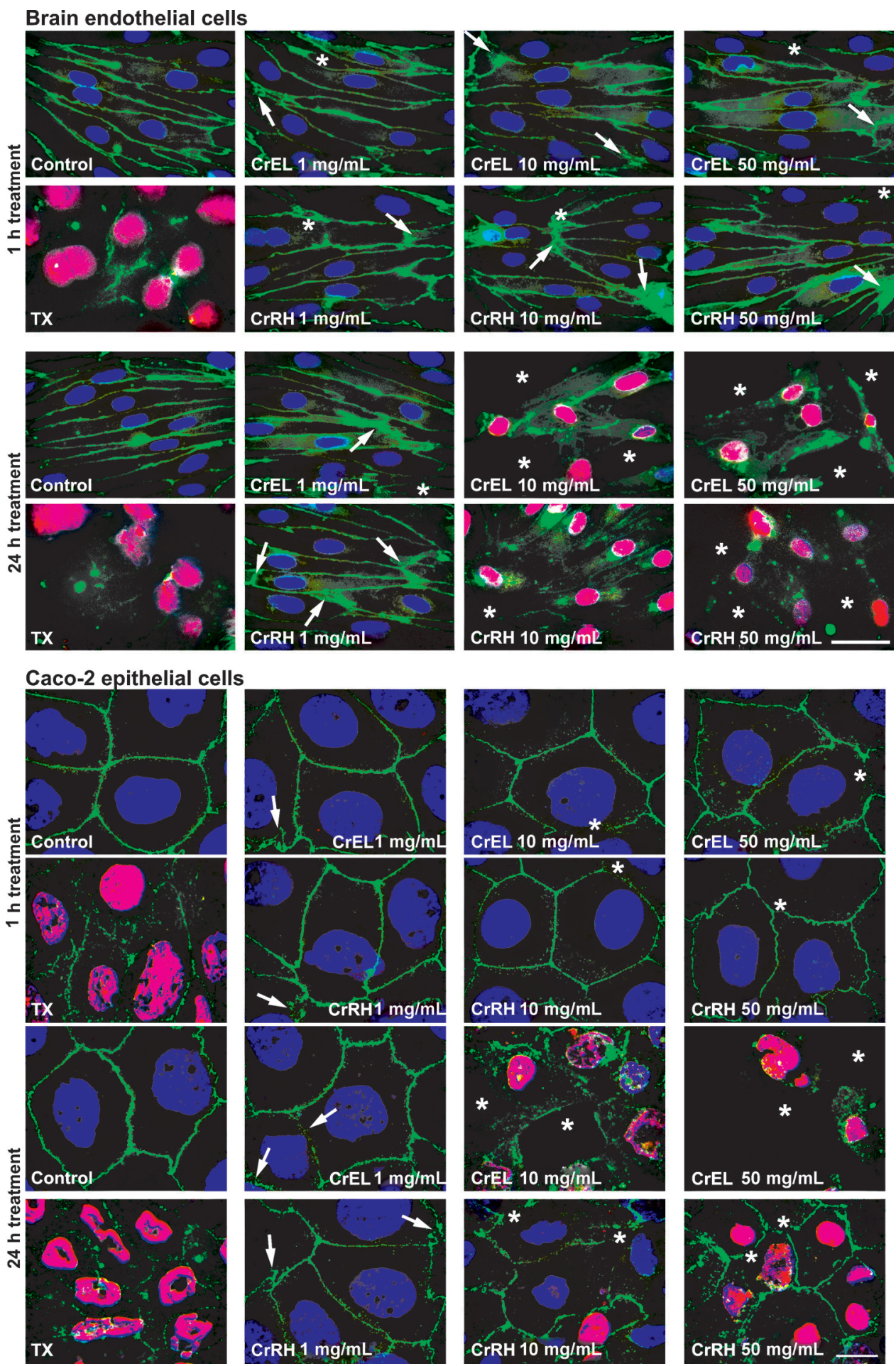

Figure 4. Fluorescent staining of cell nuclei and tight junction membrane protein claudin-5 in primary rat brain endothelial cells and claudin-4 in Caco-2 epithelial cells after 1- and 24-h treatment with Cremophors. Blue color, cell nuclei of living cells; red color, dead cells; green color, claudin immunostaining. Asterix, holes formed between cells, fragmentation or loss of junctional immunostaining; arrows, changes in claudin immunostaining of cell membranes; CrEL, Cremophor EL; CrRH, Cremophor RH40; TX, Triton X-100. Endothelial cells, bar = $30 \mu \mathrm{m}$; epithelial cells, bar $=10 \mu \mathrm{m}$. 
RH40 that can contribute to higher damage at equal concentrations. ${ }^{33}$

\section{CONCLUSIONS}

The effects of pharmaceutical excipients Cremophor EL and RH40 on the viability of cultured human endothelial and intestinal epithelial cells were compared for the first time. Cremophor EL was more toxic than Cremophor RH40 in both cell types. Endothelial cells were more sensitive than intestinal epithelial cells to treatments with Cremophors measured by RTCES, colorimetric viability assays, and morphological methods. The observed changes in endothelial cells may be related to the side effects of Cremophor EL in vivo.

\section{ACKNOWLEDGMENTS}

Project title: Broadening the knowledge base and supporting the long-term professional sustainability of the Research University Centre of Excellence at the University of Szeged by ensuring the rising generation of excellent scientists. Project number: TÁMOP4.2.2/B-10/1-2010-0012.

\section{REFERENCES}

1. Deli MA. 2009. Potential use of tight junction modulators to reversibly open membranous barriers and improve drug delivery. Biochim Biophys Acta 1788:892-910.

2. Strickley RG. 2004. Solubilizing excipients in oral and injectable formulations. Pharm Res 21:201-230.

3. Grant RL, Yao C, Gabaldon D, Acosta D. 1992. Evaluation of surfactant cytotoxicity potential by primary cultures of ocular tissues: I. Characterization of rabbit corneal epithelial cells and initial injury and delayed toxicity studies. Toxicology 76:153-176.

4. Gelderblom H, Verweij J, Nooter K, Sparreboom A. 2001. Cremophor EL: The drawbacks and advantages of vehicle selection for drug formulation. Eur J Cancer 37:1590-1598.

5. Weiszhár Z, Czúcz J, Révész C, Rosivall L, Szebeni J, Rozsnyay Z. 2012. Complement activation by polyethoxylated pharmaceutical surfactants: Cremophor-EL, Tween-80 and Tween-20. Eur J Pharm Sci 45:492-498.

6. Windebank AJ, Blexrud MD, de Groen PC. 1994. Potential neurotoxicity of the solvent vehicle for cyclosporine. J Pharmacol Exp Ther 268:1051-1056.

7. Tatou E, Mossiat C, Maupoil V, Gabrielle F, David M, Rochette L. 1996. Effects of cyclosporin and cremophor on working rat heart and incidence of myocardial lipid peroxidation. Pharmacology 52:1-7.

8. Yamaguchi JY, Nishimura Y, Kanada A, Kobayashi M, Mishima K, Tatsuishi T, Iwase K, Oyama Y. 2005. Cremophor $\mathrm{EL}$, a non-ionic surfactant, promotes $\mathrm{Ca}(2+)$-dependent process of cell death in rat thymocytes. Toxicology 211:179186.

9. Csóka K, Dhar S, Fridborg H, Larsson R, Nygren P. 1997. Differential activity of Cremophor EL and paclitaxel in patients' tumor cells and human carcinoma cell lines in vitro. Cancer 79:1225-1233.
10. Maroju RK, Turner DC, Zhang H. 2010. Solubilizing efficiency and in vitro cytotoxicity of peptoad G. J Pharm Sci 99:2196-2198.

11. Sanchez H, Bigard X, Veksler V, Mettauer B, Lampert E, Lonsdorfer J, Ventura-Clapier R. 2000. Immunosuppressive treatment affects cardiac and skeletal muscle mitochondria by the toxic effect of vehicle. J Mol Cell Cardiol 32:323-331.

12. Hugger ED, Novak BL, Burton PS, Audus KL, Borchardt RT. 2002. A comparison of commonly used polyethoxylated pharmaceutical excipients on their ability to inhibit P-glycoprotein activity in vitro. J Pharm Sci 91:1991-2002.

13. Gutiérrez MB, Miguel BS, Villares C, Gallego JG, Tuñón MJ. 2006. Oxidative stress induced by Cremophor EL is not accompanied by changes in NF-kappaB activation or iNOS expression. Toxicology 222:125-131.

14. Cao FH, OuYang WQ, Wang YP, Yue PF, Li SP. 2011. A combination of a microemulsion and a phospholipid complex for topical delivery of oxymatrine. Arch Pharm Res 34:551-562.

15. Gursoy RN, Benita S. 2004. Self-emulsifying drug delivery systems (SEDDS) for improved oral delivery of lipophilic drugs. Biomed Pharmacother 58:173-182.

16. Sakeer K, Al-Zein H, Hassan I, Desai S, Nokhodchi A. 2010. Enhancement of dissolution of nystatin from buccoadhesive tablets containing various surfactants and a solid dispersion formulation. Arch Pharm Res 33:1771-1779.

17. Horvát S, Fehér A, Wolburg H, Sipos P, Veszelka S, Tóth A, Kis L, Kurunczi A, Balogh G, Kürti L, Erôs I, Szabó-Révész P, Deli MA. 2009. Sodium hyaluronate as a mucoadhesive component in nasal formulation enhances delivery of molecules to brain tissue. Eur J Pharm Biopharm 72:252-259.

18. Karpf DM, Holm R, Garafalo C, Levy E, Jacobsen J, Müllertz A. 2006. Effect of different surfactants in biorelevant medium on the secretion of a lipophilic compound in lipoproteins using Caco-2 cell culture. J Pharm Sci 95:45-55.

19. Kristmundsdóttir T, Aradóttir HA, Ingólfsdóttir K, Ogmundsdóttir HM. 2002. Solubilization of the lichen metabolite (+)-usnic acid for testing in tissue culture. J Pharm Pharmacol 54:1447-1452.

20. Deli MA, Ábrahám CS, Kataoka Y, Niwa M. 2005. Permeability studies on in vitro blood-brain barrier models: Physiology, pathology, and pharmacology. Cell Mol Neurobiol 25:59-127.

21. Veszelka S, Kittel Á, Deli MA. 2011. Tools of modelling blood-brain barrier penetrability. In Solubility, delivery, and ADME problems of drug and drug-candidates; Tihanyi K, Vastag M, Eds. Washington: Bentham Science Publ. Ltd., pp 166-188.

22. Hayeshi R, Hilgendorf C, Artursson P, Augustijns P, Brodin B, Dehertogh P, Fisher K, Fossati L, Hovenkamp E, Korjamo T, Masungi C, Maubon N, Mols R, Müllertz A, Mönkkönen J, O'Driscoll C, Oppers-Tiemissen HM, Ragnarsson EG, Rooseboom M, Ungell AL. 2008. Comparison of drug transporter gene expression and functionality in Caco-2 cells from 10 different laboratories. Eur J Pharm Sci 35:383-96.

23. Weksler BB, Subileau EA, Perrière N, Charneau P, Holloway $\mathrm{K}$, Leveque M, Tricoire-Leignel H, Nicotra A, Bourdoulous S, Turowski P, Male DK, Roux F, Greenwood J, Romero IA, Couraud PO. 2005. Blood-brain barrier-specific properties of a human adult brain endothelial cell line. FASEB J 19:1872-1874.

24. Veszelka S, Pásztói M, Farkas AE, Krizbai I, Ngo TK, Niwa M, Ábrahám CS, Deli MA. 2007. Pentosan polysulfate protects brain endothelial cells against bacterial lipopolysaccharideinduced damages. Neurochem Int 50:219-228.

25. Ózsvári B, Puskás LG, Nagy LI, Kanizsai I, Gyuris M, Madácsi R, Fehér LZ, Gerö D, Szabó C. 2010. A cell-microelectronic sensing technique for the screening of cytoprotective compounds. Int J Mol Med 25:525-530.

26. Atienza JM, Yu N, Kirstein SL, Xi B, Wang X, Xu X, Abassi YA. 2006. Dynamic and label-free cell-based assays using the 
real-time cell electronic sensing system. Assay Drug Dev Technol 4:597-607.

27. Kürti L, Veszelka S, Bocsik A, Dung NT, Ózsvári B, Puskás LG, Kittel Á, Szabó-Révész P, Deli MA. 2012. The effect of sucrose esters on a culture model of the nasal barrier. Toxicol In Vitro 26:445-454.

28. Food and Drug Administration. Food and Drug Administration database for inactive ingredients in approved drug products. Accessed on 04 Dec 2012, at: http://www.accessdata. fda.gov/scripts/cder/iig/.

29. Groot RD, Rabone KL. 2001. Mesoscopic simulation of cell membrane damage, morphology change and rupture by nonionic surfactants. Biophys J 81:725-736.
30. Simons K, Toomre D. 2000. Lipid rafts and signal transduction. Nat Rev Mol Cell Biol 1:31-39.

31. Dias VC, Wallace JL, Parsons HG. 1992. Modulation of cellular phospholipid fatty acids and leukotriene B4 synthesis in the human intestinal cell $(\mathrm{CaCo}-2)$. Gut 33:622627.

32. Héliès-Toussaint C, Gambert S, Roller P, Tricot S, Lacour B, Grynberg A. 2006. Lipid metabolism in human endothelial cells. Biochim Biophys Acta 1761:765-774.

33. Christiansen A, Backensfeld T, Weitschies W. 2010. Effects of non-ionic surfactants on in vitro triglyceride digestion and their susceptibility to digestion by pancreatic enzymes. Eur $\mathrm{J}$ Pharm Sci 41:376-382. 


\section{PUBLICATION III.}




\title{
Sucrose Esters Increase Drug Penetration, But Do Not Inhibit P-Glycoprotein in Caco-2 Intestinal Epithelial Cells
}

\author{
LÓRÁND KISS,,${ }^{1,2}$ ÉVA HELLINGER, ${ }^{3}$ ANA-MARIA PILBAT, ${ }^{4}$ ÁGNES KITTEL, ${ }^{5}$ ZSOLT TÖRÖK, ${ }^{4}$ ANDRÁS FÜREDI, ${ }^{6}$ \\ GERGELY SZAKÁCS, ${ }^{6}$ SZILVIA VESZELKA, ${ }^{1}$ PÉTER SIPOS, ${ }^{2}$ BÉLA ÓZSVÁRI, ${ }^{7}$ LÁSZLÓ G. PUSKÁS, ${ }^{7}$ MONIKA VASTAG, ${ }^{3}$ \\ PIROSKA SZABÓ-RÉVÉSZ, ${ }^{2}$ MÁRIA A. DELI ${ }^{1}$ \\ ${ }^{1}$ Institute of Biophysics, Biological Research Centre, Hungarian Academy of Sciences, Szeged H-6726, Hungary \\ ${ }^{2}$ Department of Pharmaceutical Technology, University of Szeged, Szeged H-6720, Hungary \\ ${ }^{3}$ Division of Pharmacology and Drug Safety Research, Gedeon Richter Plc., Budapest H-1103, Hungary \\ ${ }^{4}$ Laboratory of Molecular Stress Biology, Institute of Biochemistry, Biological Research Centre, Hungarian Academy of Sciences, Szeged \\ H-6726, Hungary \\ ${ }^{5}$ Institute of Experimental Medicine, Hungarian Academy of Sciences, Budapest $\mathrm{H}-1083$, Hungary \\ ${ }^{6}$ Institute of Enzymology, Research Centre for Natural Sciences, Hungarian Academy of Sciences, Budapest 1117, Hungary \\ ${ }^{7}$ Avidin Ltd., Szeged H-6726, Hungary
}

Received 2 March 2014; revised 14 June 2014; accepted 16 June 2014

Published online in Wiley Online Library (wileyonlinelibrary.com). DOI 10.1002/jps.24085

\begin{abstract}
Sucrose fatty acid esters are increasingly used as excipients in pharmaceutical products, but few data are available on their toxicity profile, mode of action, and efficacy on intestinal epithelial models. Three water-soluble sucrose esters, palmitate (P-1695), myristate (M-1695), laurate (D-1216), and two reference absorption enhancers, Tween 80 and Cremophor RH40, were tested on Caco-2 cells. Caco-2 monolayers formed a good barrier as reflected by high transepithelial resistance and positive immunostaining for junctional proteins claudin-1, ZO-1, and $\beta$-catenin. Sucrose esters in nontoxic concentrations significantly reduced resistance and impedance, and increased permeability for atenolol, fluorescein, vinblastine, and rhodamine 123 in Caco-2 monolayers. No visible opening of the tight junctions was induced by sucrose esters assessed by immunohistochemistry and electron microscopy, but some alterations were seen in the structure of filamentous actin microfilaments. Sucrose esters fluidized the plasma membrane and enhanced the accumulation of efflux transporter ligands rhodamine 123 and calcein AM in epithelial cells, but did not inhibit the P-glycoprotein (P-gp)-mediated calcein AM accumulation in MES-SA/Dx5 cell line. These data indicate that in addition to their dissolution-increasing properties sucrose esters can enhance drug permeability through both the transcellular and paracellular routes without inhibiting P-gp. (C) 2014 Wiley Periodicals, Inc. and the American Pharmacists Association J Pharm Sci
\end{abstract}

Keywords: absorption enhancer; Caco-2 cells; drug permeability; efflux pumps; epithelial; membrane fluidity; P-glycoprotein; sucrose ester; tight junction; toxicity

\section{INTRODUCTION}

Drug delivery across biological barriers remains a great challenge in pharmaceutical research. One of the options to improve permeability of low-penetrating active agents is the use of absorption enhancers. ${ }^{1}$ Nonionic surface-active agents, Tween 80 , an ethoxylated sorbitan and Cremophor RH40, a castor oil ester, have been widely investigated and were demonstrated to enhance the solubility or absorption of drugs. ${ }^{2,3}$ Clinically employed surfactants have advantageous properties as absorption enhancers, ${ }^{4}$ but can also cause side effects. ${ }^{4-6}$ There is a need for new, innovative absorption enhancers with more favorable profile and fever drawbacks.

Sucrose fatty acid esters are nonionic surfactants that are present naturally in plants and microorganisms. ${ }^{7}$ Food industry applies them as food emulsifiers and food additives. ${ }^{8,9}$ Because of low-skin irritation, excellent emulsification, and

Correspondence to: Mária A. Deli (Telephone: +36-62-599602; Fax: +36-62433133; E-mail: deli.maria@brc.mta.hu)

This article contains supplementary material available from the authors upon request or via the Internet at http://onlinelibrary.wiley.com/.

Journal of Pharmaceutical Sciences

(C) 2014 Wiley Periodicals, Inc. and the American Pharmacists Association solubilizing properties, they are also used in cosmetics. ${ }^{10} \mathrm{Su}-$ crose esters are promising candidates for improving the solubility and permeability of drugs as recently reviewed by Szúcs and Szabó-Révész. ${ }^{11}$ Because of their excellent emulsifier and surfactant properties, sucrose esters were tested for transdermal drug delivery in microemulsions and reversed vesicles. ${ }^{12-16}$ The use of sucrose esters for oral application was less studied. Controlled release from matrix tablets containing sucrose esters was demonstrated. ${ }^{17}$ Daunomycin accumulation was effectively enhanced by sucrose esters in Caco- 2 intestinal cells. ${ }^{18}$ In animal studies, sucrose esters improved the intestinal permeability of the polypeptide hormone calcitonin, ${ }^{19}$ lidocaine hydrochloride, ${ }^{20}$ and cyclosporine A. ${ }^{21}$ The intestinal absorption of paracellular marker dextran was also enhanced by L1695 laurate ester treatment in rats. ${ }^{22}$ Although the paracellular barrier in intestinal cells is regulated by intercellular junctions, ${ }^{4}$ changes in tight or adherens junctions and transport pathways following sucrose fatty acid ester treatments have not been investigated yet. Sucrose esters were also described to inhibit efflux pumps, mainly P-glycoprotein (P-gp, ABCB1) in epithelial cells and in animal experiments. ${ }^{23,24}$ Although the effect of sucrose esters on cell membranes was suggested, ${ }^{24}$ it was not investigated in living cells. 
The human Caco-2 cell line is a widely used culture model for intestinal drug absorption showing good correlation with in vivo data, which structurally and functionally resembles small intestinal epithelium. ${ }^{25-27}$ Cells are polarized, grow in monolayer, possess microvilli, form tight intercellular connections by apical junctional complexes, and express solute carriers, and efflux transporters such as P-gp, BCRP, or MRP-2. ${ }^{25,28,29}$

Our aim was to test the effects of three different sucrose esters, namely, palmitate (P-1695), myristate (M-1695), and laurate (D-1216) esters, on the viability, passive permeability, junctional and cytoskeletal morphology, membrane fluidity, and efflux pump activity of Caco-2 intestinal epithelial cells in relation to reference absorption enhancers Tween 80 and Cremophor RH40. The toxicity of surfactants was determined by standard colorimetric end-point assays. The barrier properties were tested by resistance and impedance measurements. To assess passive and efflux transport across epithelial monolayers atenolol, caffeine, antipyrine, vinblastine, fluorescein, and rhodamine 123 were examined in the presence or absence of surfactants. Junctional morphology monitored by immunostaining for claudin-1, zonula occludens protein-1 (ZO-1), $\beta$-catenin, and transmission electron microscopy, and plasma membrane fluidity were investigated for the first time in sucrose ester-treated Caco-2 cells. Filamentous actin (F-actin), a main cytoskeletal protein contributing to normal organization of junctions was also studied. The effect of the sucrose esters on efflux pump activity was determined in Caco-2 cells; P-gp functionality was measured on MES-SA and MES-SA/Dx5 cell lines.

\section{MATERIALS AND METHODS}

\section{Materials}

All reagents were purchased from Sigma-Aldrich Ltd. (Budapest, Hungary), unless otherwise indicated. Laurate sucrose ester (D-1216) was of pharmaceutical grade; palmitate (P-1695) and myristate (M-1695) sucrose esters were of analytical grade (Mitsubishi Kagaku Foods Company, Tokyo, Japan). Tween 80 and Cremophor RH40 (BASF, Ludwigshafen am Rhein, Germany) were of pharmaceutical grade. Supplementary Table S1 summarizes some of the properties of the surfactants employed in the study.

\section{Cell Culture}

Human intestinal epithelial Caco-2 (ATCC catalog no. HTB-37, USA) cell line was used in the experiments. To obtain a more uniform morphology and higher efflux pump expression, cells were treated with vinblastine $(10 \mathrm{nM})$ for at least six passages as described by Hellinger et al. ${ }^{26}$ Cells were grown in Eagle's Minimal Essential Medium (Gibco, Life Technologies, Carlsbad, California) supplemented with $10 \%$ fetal bovine serum (Lonza, Basel, Switzerland), sodium-pyruvate (Gibco, Life Technologies), and $50 \mu \mathrm{g} / \mathrm{mL}$ gentamicin in a humidified $37^{\circ} \mathrm{C}$ incubator with $5 \% \mathrm{CO}_{2}$. Cells were seeded in culture dishes at a density of $5 \times 10^{4}$ cells $/ \mathrm{cm}^{2}$ and the medium was changed every 2 days. When cells reached approximately 80\%-90\% confluence in the dish, they were subcultured with $0.05 \%$ trypsin Ethylenediaminetetraacetic acid solution. For the cytotoxicity assays, cells were cultured in 96-well plates (Orange Scientific, Braine-l'Alleud, Belgium) and for real-time cell electronic sensing (RT-CES), 96-well plates with gold electrodes (E-plate 96; ACEA Biosciences, San Diego, California) were used. For electric resistance measurements and permeability studies, Caco-2 cells were cultured on transwell inserts (polycarbonate membrane, $0.4 \mu \mathrm{m}$ pore size, $1.12 \mathrm{~cm}^{2}$ surface area; Corning Life Sciences, Tewksbury, Massachusetts). For staining of nuclei, junctions and F-actin cells were grown on glass coverslips (Menzel-Gläser, Braunschweig, Germany). All surfaces were coated with $0.05 \%$ rat tail collagen before cell seeding, unless otherwise indicated.

Human uterine sarcoma lines MES-SA, and its doxorubicinselected derivative expressing high levels of P-gp (MES$\mathrm{SA} / \mathrm{Dx} 5)$ were used for testing P-gp functionality. ${ }^{30}$ Cells were grown in Dulbecco's modified Eagle medium (DMEM; Gibco, Life Technologies) supplemented with $10 \%$ fetal bovine serum, $5 \mathrm{mM}$ L-glutamine, and $50 \mathrm{unit} / \mathrm{mL}$ penicillin/streptomycin. To maintain homogenous $\mathrm{P}$-gp expression, MES-SA/Dx5 cells were treated with $500 \mathrm{nM}$ doxorubicin for at least two passages before the experiments.

\section{Cell Viability Measurements}

Treatment concentrations of sucrose esters P-1695, M-1695, and D-1216 varied between 3 and $3000 \mu \mathrm{g} / \mathrm{mL}$. The reference absorption enhancers were used in $1-100,000 \mu \mathrm{g} / \mathrm{mL}$ concentrations. Treatment solutions were prepared in DMEM without phenol red. Triton X-100 (10 mg/mL) was used as a toxicity control.

(3-(4,5-Dimethyltiazol-2-yl)-2,5-diphenyltetrazolium bromide) (MTT) dye conversion was used to measure cell metabolic activity and viability. Caco-2 epithelial cells were cultured in 96-well plates for 3 days. Confluent cultures were treated for 1 or $24 \mathrm{~h}$, washed with phosphate-buffered saline (PBS; $\mathrm{pH} 7.4$ ) and incubated with $0.5 \mathrm{mg} / \mathrm{mL}$ MTT solution for $3 \mathrm{~h}$ in a $\mathrm{CO}_{2}$ incubator. The amount of blue formazan crystals converted by cells was dissolved in dimethyl sulfoxide and determined by measuring absorbance at $595 \mathrm{~nm}$ wavelength with a microplate reader (Fluostar Optima; BMG Labtechnologies, Ortenberg, Germany). Cell viability was calculated as percentage of dye conversion by nontreated cells.

Lactate dehydrogenase ( $\mathrm{LDH})$ release, the indicator of cell membrane damage, was determined from culture supernatants by "Cytotoxicity detection kit (LDH)" (Roche, Basel, Switzerland). Caco- 2 cells cultured in 96-well plates for 3 days were treated for 1 or $24 \mathrm{~h}$ with absorption enhancers, and then $50 \mu \mathrm{L}$ samples from culture supernatants were incubated with equal amounts of reaction mixture for $15 \mathrm{~min}$. The enzyme reaction was stopped by $0.1 \mathrm{M} \mathrm{HCl}$. Absorbance was measured at a wavelength of $492 \mathrm{~nm}$ with a microplate reader (Fluostar Optima; BMG Labtechnologies). Cell death was calculated as percentage of the total LDH release from cells treated by $10 \mathrm{mg} / \mathrm{mL}$ Triton $\mathrm{X}-100$. The nontoxic concentrations (TC0), 50\% toxic concentrations (TC50), and concentrations causing death in all cell (TC100) were calculated from fitted curves (GraphPad Prism 5.0; GraphPad Software Inc., San Diego, California); equations are shown in Supporting Information 1.

\section{Measurement of Electrical Resistance and Impedance of Cell Layers}

Transepithelial electrical resistance (TEER) was measured by an EVOM resistance meter using STX-2 electrodes (World Precision Instruments Inc., Sarasota, Florida) and expressed relative to the surface area $\left(\Omega \times \mathrm{cm}^{2}\right)$. TEER represents the paracellular permeability of cell layers for ions. The TEER of Caco-2 
monolayers was $800 \pm 138 \Omega \times \mathrm{cm}^{2}$ (mean $\left.\pm \mathrm{SD} ; n=158\right)$ after 3 weeks of culture. Resistance measurements were carried out before and after permeability studies to check the barrier integrity.

Impedance was measured at $10 \mathrm{kHz}$ by RTCA SP instrument (ACEA Biosciences) and reflects the permeability of cellular membranes in confluent cultures. ${ }^{31,32}$ Impedance noninvasively quantifies proliferation, viability, or permeability of adherent cells in real time. ${ }^{6,33,34}$ E-plates with gold electrodes were coated with $0.2 \%$ gelatine-PBS solution for $20 \mathrm{~min}$ at $37^{\circ} \mathrm{C}$. Culture medium $(80 \mu \mathrm{L})$ was added to each well for background readings and then $80 \mu \mathrm{L}$ cell suspension was dispensed at the density of $6 \times 10^{3}$ cells/well. The cells were kept in incubator at $37^{\circ} \mathrm{C}$ for $48 \mathrm{~h}$ and monitored every $5 \mathrm{~min}$. The impedance at each time point was defined as $R_{\mathrm{n}}-R_{\mathrm{b}}$, where $R_{\mathrm{n}}$ is the cell-electrode impedance of the well when it contains cells and $R_{\mathrm{b}}$ is the background impedance of the well with the medium alone. During treatments, cells impedance was measured every $2 \mathrm{~min}$.

\section{Permeability Study}

The flux of the drugs caffeine, antipyrine, atenolol, vinblastine, and fluorescent dyes fluorescein and rhodamine 123 across epithelial cell layers was determined in apical to basal $(\mathrm{AB}) \mathrm{di}$ rection. The flux of vinblastine, fluorescein, and rhodamine 123 was also measured in basal to apical (BA) direction. Caco-2 cells were seeded onto transwell filter inserts, and the resistance of the cell layers was checked twice a week. After 21 days when the resistance was high and stable, the inserts were transferred to 12-well plates containing $1.5 \mathrm{~mL}$ Ringer-HEPES solution (150 $\mathrm{mM} \mathrm{NaCl}, 6 \mathrm{mM} \mathrm{NaHCO}$, $5.2 \mathrm{mM} \mathrm{KCl}, 2.2 \mathrm{mM} \mathrm{CaCl}_{2}, 0.2 \mathrm{mM}$ $\mathrm{MgCl}_{2}, 2.8 \mathrm{mM}$ D-glucose, $5 \mathrm{mM}$ HEPES, pH 7.4) in the basolateral compartments. In apical chambers, culture medium was replaced by $500 \mu \mathrm{L}$ Ringer-HEPES-containing drugs or marker molecules with or without absorption enhancers. The drugs and rhodamine 123 were used at $10 \mu \mathrm{M}$; fluorescein was administered at $10 \mu \mathrm{g} / \mathrm{mL}$ concentration. Absorption enhancers were applied in the apical compartment in the following concentrations: Tween 80 and Cremophor RH40 at 30, 60, 100, and 1000 $\mu \mathrm{g} / \mathrm{mL} ; \mathrm{P}-1695$ and M-1695 at 30 and $60 \mu \mathrm{g} / \mathrm{mL}$; and D-1216 at 30,60 , and $100 \mu \mathrm{g} / \mathrm{mL}$. The plates were kept in a $\mathrm{CO}_{2}$ incubator on a rocking platform ( $100 \mathrm{rpm})$ for $1 \mathrm{~h}$ in case of atenolol, caffeine, antipyrine, and rhodamine 123 . For vinblastine and fluorescein, 2-h permeability test was performed, and samples were taken from the acceptor phase at both 1 and $2 \mathrm{~h}$ time points. After the incubation, samples from the upper and lower compartments were collected and the concentrations of fluorescein and rhodamine 123 were determined by a fluorescent microplate reader (Fluostar Optima; BMG Labtechnologies), whereas drug concentrations were measured by HPLC, as detailed below. The apparent permeability coefficients $\left(P_{\text {app }}\right)$ in $\mathrm{AB}$ and $\mathrm{BA}$ directions, and the clearance of the molecules were calculated (Supporting Information Eqs. 3-7).

\section{HPLC Analytical Procedures}

Analytical measurements were performed on a Merck-Hitachi LaChrom HPLC system equipped with UV and fluorescence detector (Merck, Darmstadt, Germany). Antipyrine and vinblastine were determined by using Purospher C18e $125 \times$ $3 \mathrm{~mm}^{2}(5 \mu \mathrm{m}$ ) column (Merck) operated at $0.5 \mathrm{~mL} / \mathrm{min}$ flow rate, maintained at $40^{\circ} \mathrm{C}$. Mobile phase for antipyrine consisted of
$40 \%$ methanol in $0.1 \mathrm{M}$ ammonium acetate with isocratic elution. UV detection was at $250 \mathrm{~nm}$ wavelength. The calibration curve showed a good linearity within the examined concentration range of $0.1-10 \mu \mathrm{M}\left(r^{2}=0.999\right)$. For vinblastine, elution was applied to a mixture of $250 \mathrm{~mL}$ methanol, $200 \mathrm{~mL} 25 \mathrm{nM}$ ammonium acetate, and $3 \mathrm{~mL} \mathrm{10 \%} \mathrm{trifluoroacetic} \mathrm{acid.} \mathrm{Vinblas-}$ tine was quantified at $275 / 360 \mathrm{~nm}$ excitation/emission wavelengths. The calibration curve was linear with an $r^{2}=0.998$ in the range of 0.01-1 $\mu \mathrm{M}$. Samples with higher than $1 \mu \mathrm{M}$ vinblastine concentration were $10 \times$ diluted in Ringer-HEPES solution. HPLC measurement of caffeine was performed using Purospher C18e $125 \times 4 \mathrm{~mm}^{2}(5 \mu \mathrm{m})$ column (Merck) operated at $0.8 \mathrm{~mL} / \mathrm{min}$ flow rate, maintained at $35^{\circ} \mathrm{C}$. Mobile phase was $15 \%$ methanol in $0.1 \mathrm{M}$ ammonium acetate. UV detection was at $275 \mathrm{~nm}$. The $r^{2}$ of the calibration curve was 0.999 in the concentration range of $0.1-10 \mu \mathrm{M}$. Samples with atenolol were injected onto a Gemini C18e $150 \times 3 \mathrm{~mm}^{2}(5 \mu \mathrm{m})$ column (Phenomenex Inc., Aschaffenburg, Germany) operated at $35^{\circ} \mathrm{C}$ and at an eluent flow rate of $0.5 \mathrm{~mL} / \mathrm{min}$. Elution was applied to a mixture of $300 \mathrm{~mL}$ methanol, $400 \mathrm{~mL} 0.1 \mathrm{M}$ ammonium acetate, $20 \mathrm{~mL} 10 \%$ ammonium hydroxide, and $2 \mathrm{~mL}$ $0.1 \mathrm{M} \mathrm{Na}_{2}$-EDTA. Atenolol was quantified at 230/300 nm excitation/emission wavelengths. The calibration curve was linear with an $r^{2}=0.999$ in the range of $0.01-1 \mu$ M. Samples with higher than $1 \mu \mathrm{M}$ atenolol concentration were diluted $10 \times$ in Ringer-HEPES solution.

\section{Fluorescent and Immunostainings}

Morphology and cell-cell connections of Caco-2 cells were confirmed by immunostaining for claudin-1, zonula occludens protein 1 (ZO-1), and $\beta$-catenin. F-actin was stained by fluorescently labeled phalloidin, and cell nuclei by bis-benzimide dye (Hoechst dye 33342). Cell layers were grown on glass coverslips and treated with absorption enhancers $(\mathrm{P}-169530 \mu \mathrm{g} / \mathrm{mL}$, M-1695 $60 \mu \mathrm{g} / \mathrm{mL}, \mathrm{D}-1216100 \mu \mathrm{g} / \mathrm{mL}$, and Tween 80 and Cremophor RH40 $1000 \mu \mathrm{g} / \mathrm{mL}$ ) for $1 \mathrm{~h}$. Cytochalasin D, an inhibitor of actin polymerization, was applied at $2 \mu \mathrm{g} / \mathrm{mL}$ concentration. After treatments, the cultures were washed twice in PBS and fixed with $4 \%$ paraformaldehyde PBS for $30 \mathrm{~min}$. Cells were blocked with $3 \%$ bovine serum albumin in PBS and incubated with primary antibodies anti-claudin-1, anti-ZO- 1 , and anti- $\beta$ catenin (Gibco, Life Technologies) overnight. Incubation with secondary antibody Cy3-labeled antirabbit IgG, Alexa Fluor 488 Phalloidin (Gibco, Life Technologies), and bis-benzimide lasted for $1 \mathrm{~h}$. Between and after incubations, cells were washed three times with PBS. Coverslips were mounted by fluoromount and staining was examined by a Leica SP5 confocal microscope (Leica Microsystems GmbH, Wetzlar, Germany).

\section{Electron Microscopy}

Cells grown on culture inserts were treated with absorption enhancers (P-1695 $30 \mu \mathrm{g} / \mathrm{mL}, \mathrm{M}-169560 \mu \mathrm{g} / \mathrm{mL}, \mathrm{D}-1216$ $100 \mu \mathrm{g} / \mathrm{mL}$, and Tween 80 and Cremophor RH40 $1000 \mu \mathrm{g} / \mathrm{mL}$ ) for $1 \mathrm{~h}$. After treatments, cells were washed by PBS and fixed with $3 \%$ paraformaldehyde containing $0.5 \%$ glutaraldehyde in cacodylate buffer ( $\mathrm{pH} 7.4$ ) for $30 \mathrm{~min}$ at $4^{\circ} \mathrm{C}$. After washing with the buffer several times, cells were postfixed in $1 \% \mathrm{OsO}_{4}$ for $30 \mathrm{~min}$. Following a rinse with distilled water, the cells were dehydrated in graded ethanol and block stained with $1 \%$ uranyl acetate in $50 \%$ ethanol for $1 \mathrm{~h}$. After the last step of dehydration, inserts were placed in the 1:1 mixture of ethanol 
and Taab 812 (Taab; Aldermaston, Berks, UK) for 30 min at $30^{\circ} \mathrm{C}$. Finally, the membranes of the culture inserts with the cells were removed from their support and embedded in Taab 812. Polymerization was performed overnight at $60^{\circ} \mathrm{C}$. Ultrathin sections were cut perpendicularly for the membrane using a Leica UCT ultramicrotome (Leica Microsystems, Milton Keynes, UK) and examined using a Hitachi 7100 transmission electron microscope (Hitachi Ltd., Tokyo, Japan).

\section{Measurement of Plasma Membrane Fluidity in Caco-2 Cells}

Caco-2 cells were collected by trypsinization, washed twice, and resuspended in PBS. The density of cells was set by absorbance measurement at $360 \mathrm{~nm}$ to $\mathrm{OD}_{360}=0.1$ (Hewlett Packard 8452A Diode Array Spectrophotometer). Cells were labeled with $0.2 \mu \mathrm{M}$ TMA-DPH [1-(4-trimethylammoniumphenyl)-6phenyl-1,3,5-hexatriene; Molecular Probes, Life Technologies] for $5 \mathrm{~min}$. Fluorescence anisotropy was measured on a T-format fluorescence spectrometer (Quanta Master QM-1; Photon Technology International, Princeton, New Jersey). Excitation and emission wavelengths were 360 and $430 \mathrm{~nm}$, respectively (5$\mathrm{nm}$ slits). Cells were kept at $37^{\circ} \mathrm{C}$ under stirring conditions. ${ }^{35,36}$ Anisotropy data were acquired in every second. After $5 \mathrm{~min}$, the lowest concentrations of treatment solutions were added rapidly to the cell suspension and every $3 \mathrm{~min}$ the treatment concentration was increased during anisotropy measurements. Control cells received only vehicle. A strong membrane fluidizer, benzyl alcohol (30 mM) (Merck), was used as a positive control in the experiments. The following treatment concentrations were applied: $1,10,30,60$, and $100 \mu \mathrm{g} / \mathrm{mL}$ for sucrose esters; and 1, 10, 100, and $1000 \mu \mathrm{g} / \mathrm{mL}$ for Tween 80 and Cremophor RH40. The average of 50 anisotropy measurements in the last $1 \mathrm{~min}$ of each treatment concentration was calculated and compared with the anisotropy of the vehicle-treated cells at the same time point.

\section{Measurement of Efflux Pump Activity}

The activity of efflux pumps was determined by cellular accumulation of rhodamine 123 and calcein AM (Gibco, Life Technologies) in Caco-2 epithelial cells grown in 24-well plates for 2 days (seeding density: $10^{5}$ cells/well). In the pretreatment experiments, cells were incubated with surfactants P-1695 (30 $\mu \mathrm{g} / \mathrm{mL}), \mathrm{M}-1695$ (60 $\mu \mathrm{g} / \mathrm{mL}), \mathrm{D}-1216(100 \mu \mathrm{g} / \mathrm{mL})$, Tween 80 (1000 $\mu \mathrm{g} / \mathrm{mL})$, Cremophor RH40 (1000 $\mu \mathrm{g} / \mathrm{mL})$ or efflux pump inhibitors verapamil $(100 \mu \mathrm{M})$, and cyclosporin $\mathrm{A}(10 \mu \mathrm{M})$ for $1 \mathrm{~h}$, and then the cell layers were washed and incubated with $10 \mu \mathrm{M}$ rhodamine 123 in Ringer-HEPES solution for another $1 \mathrm{~h}$. In the cotreatment experiments, cells were preincubated with Ringer-HEPES buffer for 20 min. Treatments with surfactants or efflux pump inhibitors were carried out in the presence of rhodamine 123 for $1 \mathrm{~h}$. Following incubations, cells were washed three times with ice-cold PBS and lysed with $0.1 \mathrm{M}$ $\mathrm{NaOH}$ in both types of experiments. Rhodamine 123 concentration was determined by a fluorescent microplate reader (excitation wavelength: $485 \mathrm{~nm}$, emission wavelength: $520 \mathrm{~nm}$; Fluostar Optima; BMG Labtechnologies).

The calcein AM assay can be used for the measurement of the activity of efflux transporters P-gp and multidrug resistance protein-1 or -2 (MRP-1 and MRP-2). ${ }^{24,37}$ For calcein AM assay, Caco- 2 cells were seeded on 96 -well plate (cell density: $7 \times 10^{4}$ cells/well) and grown for $24 \mathrm{~h}$. In the pretreatment experiments, cells were incubated for $1 \mathrm{~h}$ with surfactants or efflux pump inhibitors. After the treatments, cells were washed and the buffer solution was replaced with $1.25 \mu \mathrm{M}$ calcein AM in Ringer-HEPES, and the plate was immediately placed in a microplate reader (Fluostar Optima; BMG Labtechnologies). The fluorescence was measured at 5 min intervals for $1 \mathrm{~h} \mathrm{(ex-}$ citation wavelength: $485 \mathrm{~nm}$; emission wavelength: $520 \mathrm{~nm}$ ). In the cotreatment experiments, cells were preincubated with Ringer-HEPES for 20 min. Treatments with surfactants or efflux pump inhibitors were performed in the presence of $1.25 \mu \mathrm{M}$ calcein AM. Fluorescence was immediately measured by a microplate reader at $5 \mathrm{~min}$ intervals for $1 \mathrm{~h}$. The fluorescence intensity was calculated as percentage of the control group.

To estimate the effect of sucrose esters on P-gp functionality, calcein AM accumulation was measured in the presence of the test substrates in MES-SA and MES-SA/Dx5 cells. ${ }^{38,39}$ Cells $\left(2 \times 10^{5}\right.$ cells $\left./ 100 \mu \mathrm{L}\right)$ were preincubated with verapamil $(100 \mu \mathrm{M}), \mathrm{P}-1695(30 \mu \mathrm{g} / \mathrm{mL}), \mathrm{M}-1695(30 \mu \mathrm{g} / \mathrm{mL}), \mathrm{D}-$ $1216(100 \mu \mathrm{g} / \mathrm{mL})$, Tween $80(100 \mu \mathrm{g} / \mathrm{mL})$, Cremophor RH40 $(1000 \mu \mathrm{g} / \mathrm{mL})$, or with solvent dimethyl sulfoxide (less than $0.1 \%$ ) for $5 \mathrm{~min}$ at $37^{\circ} \mathrm{C}$. M-1695 and Tween 80 were applied in lower concentrations because of different sensitivity of sarcoma cells as compared with Caco- 2 cells. Thereafter, $0.25 \mu \mathrm{M}$ calcein $\mathrm{AM}$ was added and the cells were incubated for $10 \mathrm{~min}$ at $37^{\circ} \mathrm{C}$. Cells were gated based on TO-PRO3 positivity (Gibco, Life Technologies). Samples were measured by a FACSCalibur ${ }^{\mathrm{TM}}$ flow cytometer (BD Biosciences, San Jose, California).

\section{Statistical Analysis}

All data presented are means \pm SD. Values were compared using analysis of variance (ANOVA) followed by Dunnett's test (GraphPad Prism 5.0; GraphPad Software Inc., San Diego, California). In case of fluorescein, vinblastine, and rhodamine 123 permeability and TMA-DPH anisotropy measurements, two-way ANOVA followed by Bonferroni posttest was applied. Changes were considered statistically significant at $p<0.05$. All experiments were repeated at least two times, and the number of parallel samples varied between 4 and 12 .

\section{RESULTS}

\section{Effect of Sucrose Esters on the Viability of Cultured Epithelial Cells}

The treatment of Caco- 2 cells with sucrose esters concentration and time dependently decreased MTT dye conversion indicating reduced cell viability (Fig. 1; Table 1). P-1695 and M-1695 esters significantly reduced metabolic activity of Caco- 2 cells at concentrations higher than 30 or $60 \mu \mathrm{g} / \mathrm{mL}$, respectively, and caused cell death above $200 \mu \mathrm{g} / \mathrm{mL}$ (Fig. 1a). D-1216 laurate ester was the least toxic among the investigated sucrose esters; the $100-\mu \mathrm{g} / \mathrm{mL}$ concentration did not decrease epithelial cell viability, but $200-600 \mu \mathrm{g} / \mathrm{mL}$ concentrations reduced MTT conversion in epithelial cells after $1 \mathrm{~h}$. The reference surfactants showed lower toxicity on epithelial cells. Tween 80 or Cremophor $\mathrm{RH} 40$ at $3000 \mu \mathrm{g} / \mathrm{mL}$ concentration did not reduce cell viability of epithelial cells for $1 \mathrm{~h}$ (Fig. 1a). The highest concentration of Cremophor RH40 increased MTT dye conversion in Caco-2 cells. Similar viability results to MTT test were obtained by measurements of $\mathrm{LDH}$ enzyme release indicating plasma membrane damage. The nontoxic concentrations for all sucrose esters were the same with both cell viability methods. Cell death was observed after 1 -h treatment with sucrose esters $(>300 \mu \mathrm{g} / \mathrm{mL}$ ), but Tween 80 or Cremophor RH40 did 
a

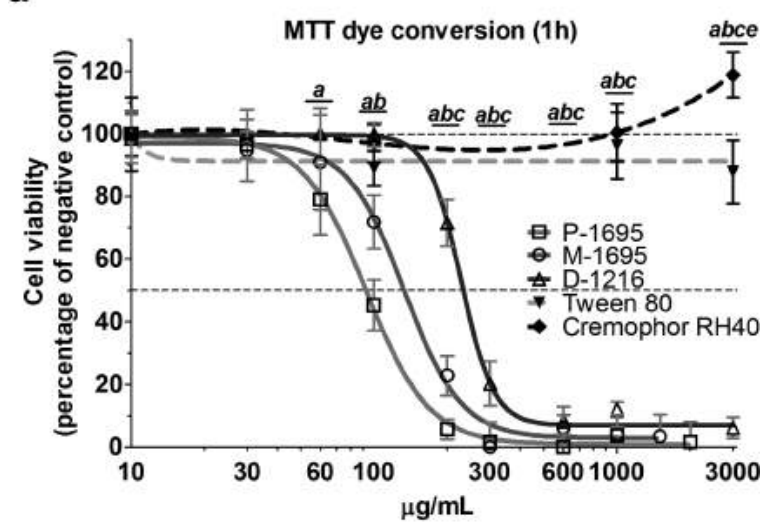

b

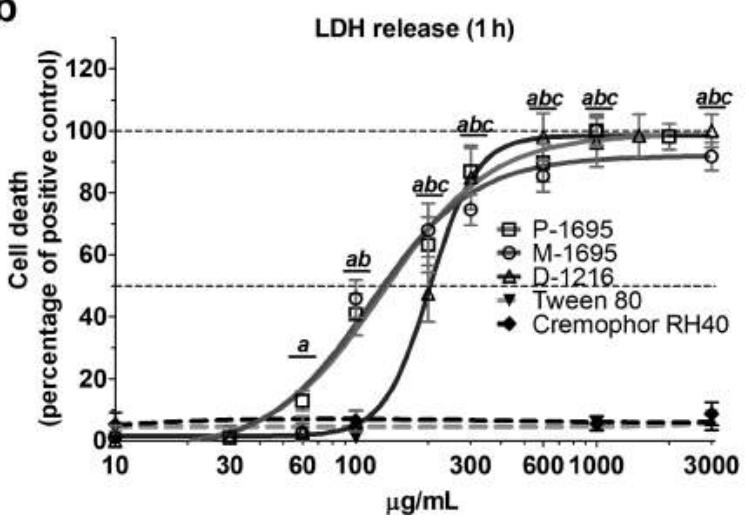

Figure 1. Toxicity of P-1695, M-1695, and D-1216 sucrose fatty acid esters (10-3000 $\mu \mathrm{g} / \mathrm{mL})$ and Tween 80 and Cremophor RH40 reference absorption enhancers $(10-3000 \mu \mathrm{g} / \mathrm{mL})$ on human Caco-2 intestinal epithelial cells measured by (a) MTT dye conversion and (b) LDH release methods. The MTT values were compared with nontreated group (100\% viability). For LDH measurement, values were compared with the Triton-X 100 treated group (100\% toxicity). Data are presented as mean $\pm \mathrm{SD}, n=6$; statistical analysis: ANOVA followed by Dunnett test; statistically significant differences $(p<0.05)$ were detected in the control group as compared with the values measured in ${ }^{\text {a }} \mathrm{P}-1695$, ${ }^{\mathrm{b}} \mathrm{M}-1695,{ }^{\mathrm{c}} \mathrm{D}-1216$, and ${ }^{\mathrm{d}}$ Cremophor RH40 groups.

not increase the enzyme release at any tested concentrations (Fig. 1b). On the basis of the results of the toxicity tests for $1 \mathrm{~h}$, the following concentrations were considered as safe for treatments and applied in further experiments on Caco-2 epithelial cells: P-1695 $30 \mu \mathrm{g} / \mathrm{mL}, \mathrm{M}-169560 \mu \mathrm{g} / \mathrm{mL}$, and D-1216 $100 \mu \mathrm{g} / \mathrm{mL}$. For reference surfactants, Tween 80 and Cre- mophor RH40, the nontoxic and clinically relevant $1000 \mu \mathrm{g} / \mathrm{mL}$ concentration, was selected for further treatments. ${ }^{6,40,41}$

The concentrations of surfactants causing $50 \%$ or complete cell death (TC 50 and TC 100) at $24 \mathrm{~h}$ were lower than for the 1-h treatments (Table 1). The nontoxic concentrations of P-1695, $\mathrm{M}-1695$, and D-1216 were about 20, 20, and $100 \mu \mathrm{g} / \mathrm{mL}$, respectively, by both assays. The toxic concentrations of reference absorption enhancers were more than one order of magnitude higher than that of sucrose esters. The TC 0 values for Tween 80 were calculated as $473 \mu \mathrm{g} / \mathrm{mL}$ (MTT test) and $1068 \mu \mathrm{g} / \mathrm{mL}$ (LDH assay). The nontoxic concentrations of Cremophor RH40 on Caco- 2 cells for $24 \mathrm{~h}$ were 30,000 and $2067 \mu \mathrm{g} / \mathrm{mL}$ determined by MTT test and LDH assay, respectively (Table 1).

\section{Effect of Sucrose Esters on the Electrical Resistance and Impedance of Epithelial Cell Layers}

Nontoxic concentrations of sucrose esters but not of reference surfactants increased the ionic permeability across Caco2 monolayers monitored by impedance and TEER measurements. Sucrose esters reduced the impedance of epithelial cell layers measured by RTCA SP (Fig. 2a). The impedance decreased rapidly from the baseline of 125 to $90 \Omega$ within $30 \mathrm{~min}$ by P-1695 $(30 \mu \mathrm{g} / \mathrm{mL})$ and D-1216 $(100 \mu \mathrm{g} / \mathrm{mL})$ treatments. M$1695(60 \mu \mathrm{g} / \mathrm{mL})$ also significantly reduced the impedance of Caco-2 layers. Slight decrease but no significant change was caused by Tween 80 or Cremophor RH40. In accordance with the impedance measurements, P-1695, M-1695, and D-1216 reduced the resistance of the cell layers to $25 \%, 55 \%$, and $62 \%$ as compared with control at 1-h treatment, but no change was observed for reference surfactants (Fig. 2b).

\section{Effect of Sucrose Esters on Caco-2 Permeability for Drugs and Fluorescein}

The permeability of hydrophilic atenolol $\left(0.17 \times 10^{-6} \mathrm{~cm} / \mathrm{s}\right)$ was low across Caco-2 cells and all surfactants significantly enhanced the penetration of atenolol across cell layers (Table 2). The $P_{\text {app }}$ of passive lipophilic drugs antipyrine $\left(80.67 \times 10^{-6}\right.$ $\mathrm{cm} / \mathrm{s})$ and caffeine $\left(87.59 \times 10^{-6} \mathrm{~cm} / \mathrm{s}\right)$ was high and the absorption enhancers did not increase it (Table 2).

The average apparent permeability coefficient of fluorescein was also low (AB: $\left.0.356 \times 10^{-6} \mathrm{~cm} / \mathrm{s} ; \mathrm{BA}: 1.82 \times 10^{-6} \mathrm{~cm} / \mathrm{s}\right)$, but higher in the BA direction (BA/AB ratio: 5.1) (Fig. 2c), indicating active efflux transport in accordance with literature data on MRP2-mediated efflux of fluorescein. ${ }^{42}$ Using previously selected nontoxic concentrations for each surfactants, all investigated compounds caused significant increase in fluorescein flux in $\mathrm{AB}$ direction across Caco-2 layers after 1 and 2-h

Table 1. Cellular Toxicity of Sucrose Esters and Reference Molecules

\begin{tabular}{|c|c|c|c|c|c|c|}
\hline \multirow[b]{2}{*}{ Absorption Enhancers } & \multicolumn{3}{|c|}{ MTT Dye Conversion } & \multicolumn{3}{|c|}{ LDH Release } \\
\hline & TC $0(\mu \mathrm{g} / \mathrm{mL})$ & TC $50(\mu \mathrm{g} / \mathrm{mL})$ & TC $100(\mu \mathrm{g} / \mathrm{mL})$ & $\mathrm{TC} 0(\mu \mathrm{g} / \mathrm{mL})$ & TC $50(\mu \mathrm{g} / \mathrm{mL})$ & TC $100(\mu \mathrm{g} / \mathrm{mL})$ \\
\hline P-1695 & 19 & 49 & 128 & 20 & 72 & 260 \\
\hline M-1695 & 18 & 62 & 211 & 20 & 61 & 189 \\
\hline D-1216 & 99 & 189 & 360 & 92 & 162 & 283 \\
\hline Tween 80 & 473 & 1073 & 2432 & 1068 & 1229 & 1621 \\
\hline Cremophor RH40 & 30,900 & 33,884 & n.a. & 2067 & 11,810 & 44,668 \\
\hline
\end{tabular}

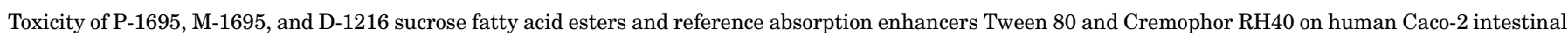

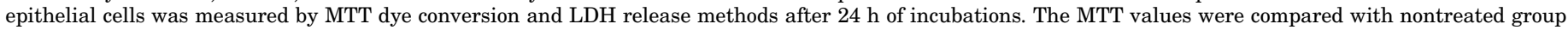
(100\% viability). For LDH, measurement groups were compared with the Triton-X 100-treated group (100\% toxicity).

TC 0 , nontoxic concentration; TC 50, caused $50 \%$ toxicity, TC $100,100 \%$ cell death; n.a., not applicable. 


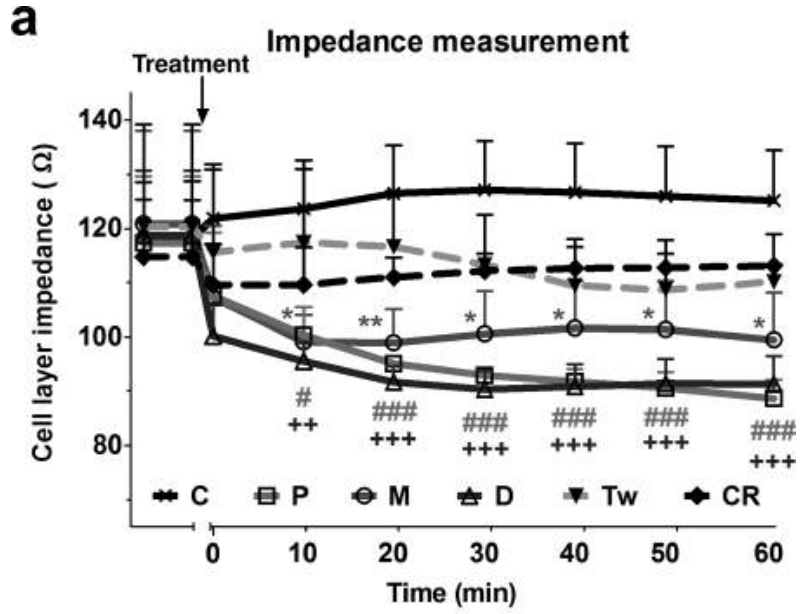

b
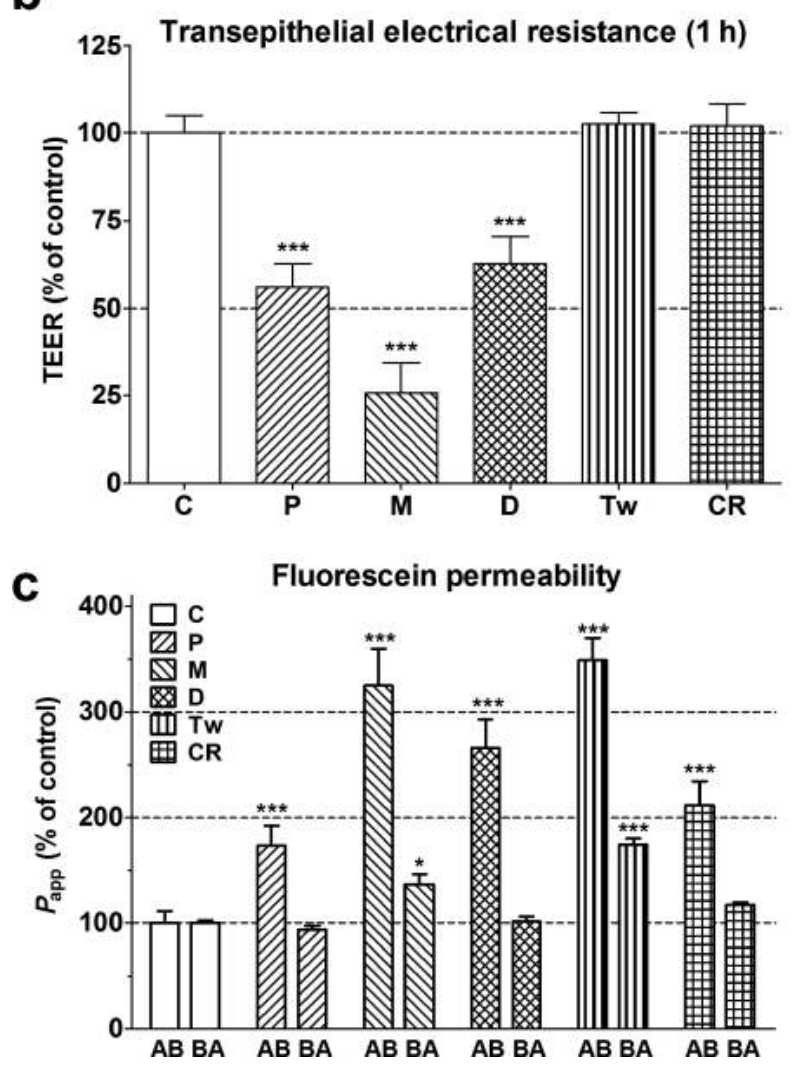

Figure 2. Effects of P-1695 (30 $\mu \mathrm{g} / \mathrm{mL}), \mathrm{M}-1695(60 \mu \mathrm{g} / \mathrm{mL})$, and D$1216(100 \mu \mathrm{g} / \mathrm{mL})$ sucrose fatty acid esters and Tween $80(1000 \mu \mathrm{g} / \mathrm{mL})$ and Cremophor RH40 (1000 $\mu \mathrm{g} / \mathrm{mL})$ reference absorption enhancers on (a) the impedance, (b) TEER, and (c) fluorescein bidirectional permeability on Caco-2 epithelial cells layer. Data are presented as mean \pm $\mathrm{SD}, n=4$; statistical analysis: ANOVA followed by Dunnett test (a and b) or two-way ANOVA followed by Bonferroni test (c). Impedance measurements (a): statistically significant differences were detected after treatment with P-1695 ( $\left.p<0.05,{ }^{\# \# \# ~} p<0.001\right)$; M-1695 ( ${ }^{*} p<0.05$ ** $p<0.01)$; D-1216 $\left({ }^{+} p<0.05,{ }^{+++} p<0.001\right)$ as compared with the control group. TEER measurements (b): statistically significant differences were detected in sucrose ester-treated groups $\left({ }^{* * * *} p<0.001\right)$ as compared with control. Fluorescein permeability (c): treatment groups were compared with their respective control in both directions $\left({ }^{*} p<\right.$ $\left.0.05,{ }^{* * * *} p<0.001\right)$. Abbreviations: C, control; P, P-1695; M, M-1695; D, D-1216; Tw, Tween 80; and CR, Cremophor RH40.
Table 2. Effect of Surfactants on Drug Permeability

\begin{tabular}{lcccc}
\hline & Passive Hydrophilic & & \multicolumn{2}{c}{ Passive Lipophilic } \\
\cline { 2 - 2 } \cline { 5 - 5 } & Atenolol & & Caffeine & Antipyrine \\
\hline $\begin{array}{c}\mathrm{P}-1695 \\
(30 \mu \mathrm{g} / \mathrm{mL})\end{array}$ & $1.46 \pm 0.02^{* * * *}$ & & $1.01 \pm 0.01$ & $0.95 \pm 0.06$ \\
$\begin{array}{c}\mathrm{M}-1695 \\
(60 \mu \mathrm{g} / \mathrm{mL})\end{array}$ & $2.37 \pm 0.63^{* * *}$ & & $0.99 \pm 0.01$ & $1.00 \pm 0.02$ \\
$\begin{array}{c}\mathrm{D}-1216 \\
(100 \mu \mathrm{g} / \mathrm{mL})\end{array}$ & $1.58 \pm 0.08^{* * * *}$ & & $0.98 \pm 0.03$ & $0.99 \pm 0.03$ \\
$\begin{array}{c}\text { Tween } 80 \\
(1000 \mu \mathrm{g} / \mathrm{mL})\end{array}$ & $2.11 \pm 0.02^{* * *}$ & & $1.06 \pm 0.02$ & $1.00 \pm 0.02$ \\
$\begin{array}{c}\text { Cremophor RH40 } \\
(1000 \mu \mathrm{g} / \mathrm{mL})\end{array}$ & $1.20 \pm 0.15^{* * *}$ & & $1.00 \pm 0.03$ & $0.98 \pm 0.01$ \\
\hline
\end{tabular}

Fold changes in the apparent permeability coefficients of atenolol, caffeine, and antipyrine measured on confluent human Caco-2 intestinal epithelial cell layers after $1 \mathrm{~h}$ treatment with P-1695, M-1695, and D-1216 sucrose fatty acid esters and Tween 80 and Cremophor RH40 reference absorption enhancers.

Data are presented as mean $\pm \mathrm{SD}, n=3$; statistical analysis: ANOVA followed by Dunnett test; ${ }^{* * * *} p<0.001$, all concentrations were compared with control.

treatments (Fig. 2c and Supplementary Fig. S1). M-1695 $(60 \mu \mathrm{g} / \mathrm{mL})$ and D-1216 $(100 \mu \mathrm{g} / \mathrm{mL})$ sucrose esters highly increased the flux of fluorescein at 1 and 2-h application (Fig. 2c). The elevation in fluorescein permeability caused by $\mathrm{P}-1695 \mathrm{su}-$ crose ester $(30 \mu \mathrm{g} / \mathrm{mL})$ was smaller, but also significant (Fig. 2c). Tween $80(1000 \mu \mathrm{g} / \mathrm{mL})$ enhanced threefold the flux of fluorescein, whereas Cremophor RH40 at similar concentration elevated the dye permeability to $211 \%$. Only M-1695 sucrose ester, Tween 80, and Cremophor RH40 enhanced significantly the fluorescein penetration in the opposite direction (BA). A lag time was observed in the penetration-enhancing effect of all surfactants based on clearance data of fluorescein in both directions in Caco-2 cells (Supplementary Figs. S1a and S1b). Sucrose esters and reference absorption enhancers were also tested at 30,60 , and $100 \mu \mathrm{g} / \mathrm{mL}$ concentrations for $1 \mathrm{~h}$ (Supplementary Figs. S2a-S2c). The effect of sucrose esters on fluorescein permeability was concentration dependent (Supplementary Figs. S2a-S2c). At $30 \mu \mathrm{g} / \mathrm{mL}$ concentration, P-1695 and M-1695 sucrose esters, but not the other surfactants (Supplementary Fig. S2a), and at $60 \mu \mathrm{g} / \mathrm{mL}$ concentration, both M-1695 and D-1216 sucrose esters increased the permeability of the dye (Supplementary Fig. S2b). D-1216 (100 $\mu \mathrm{g} / \mathrm{mL})$ raised the fluorescein flux twofold as compared with control (Supplementary Fig. S2c). In contrast with sucrose esters, reference absorption enhancers in the concentration range of $30-100 \mu \mathrm{g} / \mathrm{mL}$ did not increase the permeability of fluorescein (Supplementary Fig. S2).

\section{Effects of Sucrose Esters on the Epithelial Intercellular Junctions}

Claudin-1 transmembrane tight junction protein, ZO-1 cytoplasmic junctional linker protein, and $\beta$-catenin adherens junction protein all appeared at the cell-cell borders in a continuous, belt-like manner. Treatments with sucrose esters or reference surfactants for $1 \mathrm{~h}$ did not affect the gross morphology of cells or intercellular junctions assessed by these immunostainings (Fig. 3a). No rupture of the junctions or fragmentation of the pericellular immunostaining was seen.

Filamentous actin structure was investigated in different regions of epithelial cells. At the level of TJs, the cortical actin 

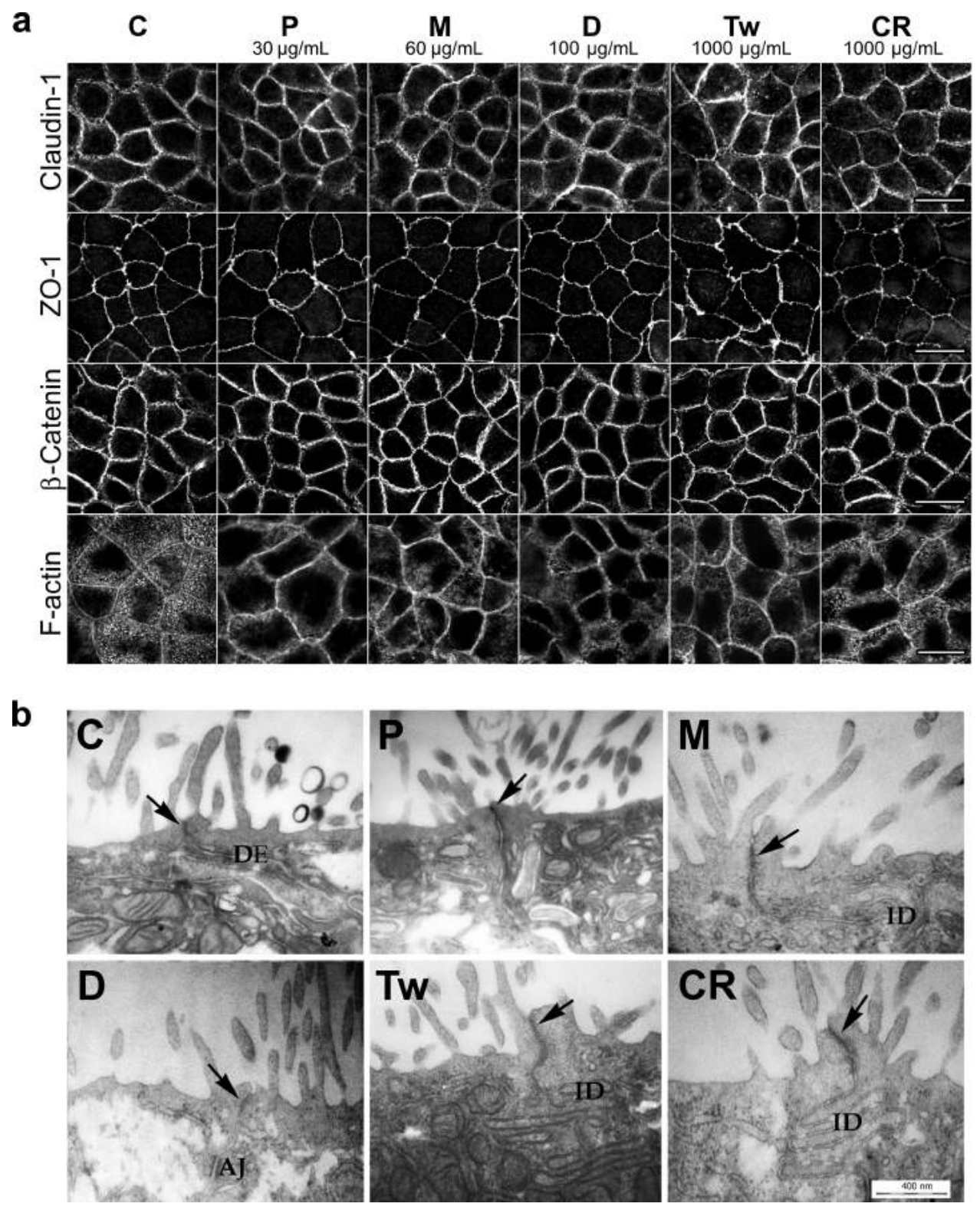

Figure 3. Effect of surfactants on cellular and junctional morphology, fluorescent immunostainings, and electron microscopy. (a) Immunostaining for tight and adherens junction membrane proteins claudin-1, zonula occludens-1, and $\beta$-catenin and fluorescent staining for F-actin microfilaments in human Caco-2 intestinal epithelial cells after $1 \mathrm{~h}$ treatment with sucrose esters and reference absorption enhancers. Bar for claudin-1, ZO-1, and $\beta$-catenin is $20 \mu \mathrm{m}$ and for F-actin is $15 \mu \mathrm{m}$. (b) Transmission electron microscopy at cell-cell connections after $1 \mathrm{~h}$ treatment with sucrose esters and reference absorption enhancers; bar $=400 \mathrm{~nm}$. Applied concentrations: P-1695, $30 \mu \mathrm{g} / \mathrm{mL} ; \mathrm{M}-1695,60 \mu \mathrm{g} / \mathrm{mL}$; D-1216, $100 \mu \mathrm{g} / \mathrm{mL}$; Tween 80, $1000 \mu \mathrm{g} / \mathrm{mL}$; and Cremophor RH40, $1000 \mu \mathrm{g} / \mathrm{mL}$. Abbreviations: C, control; P, P-1695; M, M-1695; D, D-1216; Tw, Tween 80; CR, Cremophor RH40; ZO-1, zonula occludens protein-1; arrow: tight junction; AJ: adherens junction; DE: desmosome; and ID: interdigitation.

ring was sharply delineated in the control cells mimicking TJ protein immunostainings (Fig. 3a). Following treatments with sucrose esters and reference absorption enhancers, this F-actin staining near the TJ region became wider and more blurred compared with control images. At the apical part of the cells, the structure of microvilli was well shown by F-actin staining, which was preserved in all treatment groups (Supplementary Fig. S3). At the basal part of cells, staining of F-actin revealed long filaments organized in bunches (Supplementary Fig. S3). This filamentous organization was less observed in the treatment groups, except for P-1695. Cytochalasin D, which inhibits actin polymerization, changed the F-actin staining: dot-like aggregations appeared in the actin ring at the level of TJ and in the basal area (Supplementary Fig. S3). Triton X-100 surfactant disrupted the plasma membrane and the structure of microvilli at the apical surface (Supplementary Fig. S3). The junctional actin ring was mostly preserved, but aggregations were observed in the junctional and basal areas.

The ultrastructure of TJs between Caco-2 cells was preserved in all treatment groups (Fig. 3b). No morphological change was seen by electron microscopy in the structure of apical microvilli, TJs, desmosomes, or interdigitations of adjacent 

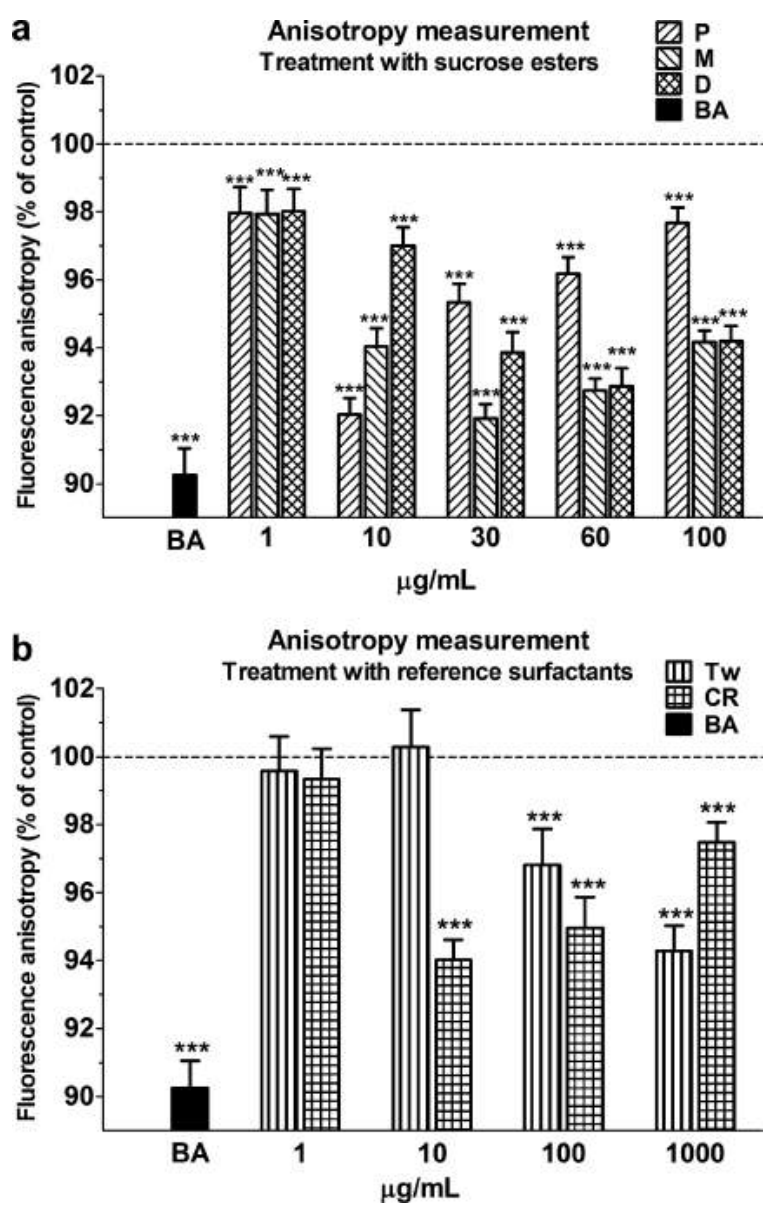

Figure 4. The effect on plasma membrane fluidity of (a) sucrose esters, (b) reference absorption enhancers, and benzyl alcohol measured by TMA-DPH fluorescence anisotropy on living Caco-2 cell suspensions. The anisotropy values in control cells were between $0.293 \pm 0.002$ and $0.286 \pm 0.002$ during the observation, and control value was considered as $100 \%$. Data are presented as mean $\pm \mathrm{SD}, n=6$; statistical analysis: two-way ANOVA followed by Bonferroni test; ${ }^{* * * *} p<0.001$, all groups were compared with control. Applied concentrations of sucrose esters: $1,10,30$, and $60,100 \mu \mathrm{g} / \mathrm{mL}$; treatment concentrations of reference surfactants: $1,10,100$, and $1000 \mu \mathrm{g} / \mathrm{mL}$. Benzyl alcohol was used at 30 $\mathrm{mM}$ concentration. Abbreviations: P, P-1695; M, M-1695; D, D-1216; Tw, Tween 80; CR, Cremophor RH40; and BA, benzyl alcohol.

epithelial cells. No open TJs were observed in the control or treatment groups by checking 140 electron micrographs (19-28 images/treatment group).

\section{Effects of Sucrose Esters on Plasma Membrane Fluidity in Caco-2 Cells}

The membrane fluidity of living epithelial cells was determined by the measurement of fluorescence anisotropy of the cationic membrane probe TMA-DPH (Fig. 4). The anisotropy slightly decreased from $0.293 \pm 0.002$ to $0.286 \pm 0.001$ in vehicle-treated Caco-2 cells after $20 \mathrm{~min}$. The membrane fluidizer benzyl alcohol quickly and greatly reduced the anisotropy: TMA-DPH fluorescence anisotropy fell to $90.2 \%$ as compared with control after $3 \mathrm{~min}$. Sucrose esters fluidized the plasma membrane of Caco-2 cells at all investigated concentrations (Fig. 4a). A Ushaped dose-response curve was observed for all sucrose esters. The biggest change in anisotropy as compared with the control group was measured at $10 \mu \mathrm{g} / \mathrm{mL}$ of P-1695 (92.0\%), $30 \mu \mathrm{g} / \mathrm{mL}$ of M-1695 (91.9\%) and $60 \mu \mathrm{g} / \mathrm{mL}$ of D-1216 (96.1\%). At higher concentrations, higher anisotropy was observed, indicating reduced membrane fluidity.

Reference absorption enhancers at $1 \mu \mathrm{g} / \mathrm{mL}$ concentration did not alter significantly membrane fluidity, in contrast to sucrose esters (Fig. 4b). Tween 80 at $10 \mu \mathrm{g} / \mathrm{mL}$ was also ineffective, but at $100 \mu \mathrm{g} / \mathrm{mL}$ and higher concentrations, statistically significantly fluidized the plasma membrane of epithelial cells with lowest anisotropy at $1000 \mu \mathrm{g} / \mathrm{mL}(94.2 \%)$. Cremophor RH40 was the most effective at $10 \mu \mathrm{g} / \mathrm{mL}$ concentration (94.0\%). Higher concentrations of reference surfactants were also less effective to reduce membrane anisotropy.

\section{Effect of Sucrose Esters on Efflux Pump Activity}

Efflux transporter activity in Caco-2 cells was measured by the cellular uptake of calcein AM, the cellular uptake and bidirectional transport of rhodamine 123, a ligand of P-gp and BCRP, ${ }^{43}$ and bidirectional permeability of vinblastine (Fig. 5). Coadministration of surfactants and rhodamine 123 resulted in statistically significant increase in the uptake of rhodamine (Fig. 5a). M-1695 and Tween 80 caused the highest, sixfold accumulation of the marker molecule compared with control. Coadministration of sucrose esters and calcein AM significantly elevated the uptake of the ligand (200\%-245\%) (Fig. 5b). Cotreatment with Tween $80(1000 \mu \mathrm{g} / \mathrm{mL})$ also significantly increased the cellular accumulation of calcein AM. In contrast to rhodamine 123 uptake, Cremophor RH40 had no effect on calcein AM uptake (Fig. 5b). Verapamil $(100 \mu \mathrm{M})$ and cyclosporin A $(10 \mu \mathrm{M})$ significantly raised the level of both ligands in Caco-2 cells (Figs. 5a and 5b).

Pretreatment with sucrose esters did not change the accumulation of rhodamine 123 in Caco-2 cells, but Tween 80 and Cremophor RH40 raised slightly the dye uptake to $133 \%$ and $117 \%$, respectively (Supplementary Fig. S4a). Pretreatment with surfactants did not significantly increase the uptake of calcein AM except for Tween 80 (113\%) (Supplementary Fig. $\mathrm{S} 4 \mathrm{~b})$. Verapamil and cyclosporin A pretreatment increased both rhodamine 123 and calcein AM accumulation in Caco-2 cells (Supplementary Fig. S4).

Rhodamine 123 permeability in $\mathrm{AB}$ direction was significantly enhanced by both absorption enhancers and efflux pump inhibitors as compared with control group $\left(0.82 \pm 0.18 \times 10^{-6}\right.$ $\mathrm{cm} / \mathrm{s}$ ) (Fig. 5c). Treatments with sucrose esters resulted in several fold elevated $\mathrm{AB}$ flux of the marker molecule as compared with reference surfactants or efflux pump inhibitors. The transport of rhodamine 123 in BA direction was unchanged by P-1695 and D-1216, but increased by M-1695. In contrast, reference absorption enhancers and efflux pump inhibitors significantly decreased rhodamine 123 permeability (Fig. 5c).

The permeability of vinblastine, a ligand of P-gp and MRP2 efflux pumps ${ }^{27}$ was measured in both directions in the absence (AB: $0.33 \times 10^{-6} \mathrm{~cm} / \mathrm{s}$; BA: $52.45 \times 10^{-6}$ ) or the presence of surfactants (Fig. 5d). All treatments increased the flux of drug in $\mathrm{AB}$ direction by several fold, and M-1695 sucrose ester had the most pronounced enhancer effect. P-1695 and D-1216 esters, and Cremophor also elevated vinblastine penetration in BA direction. Verapamil and cyclosporine A reduced the drug transport in BA direction, but Tween 80 did not.

Surfactants were also tested on MES-SA/Dx5 cells overexpressing P-gp and the parental (P-gp negative) MES-SA cell 
a
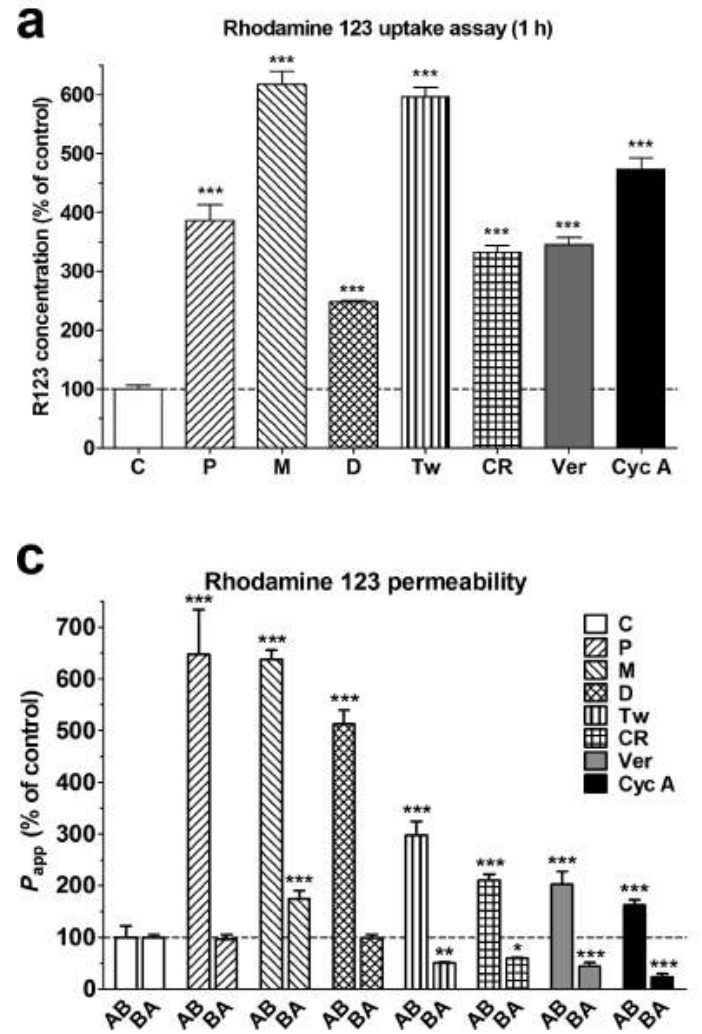

b
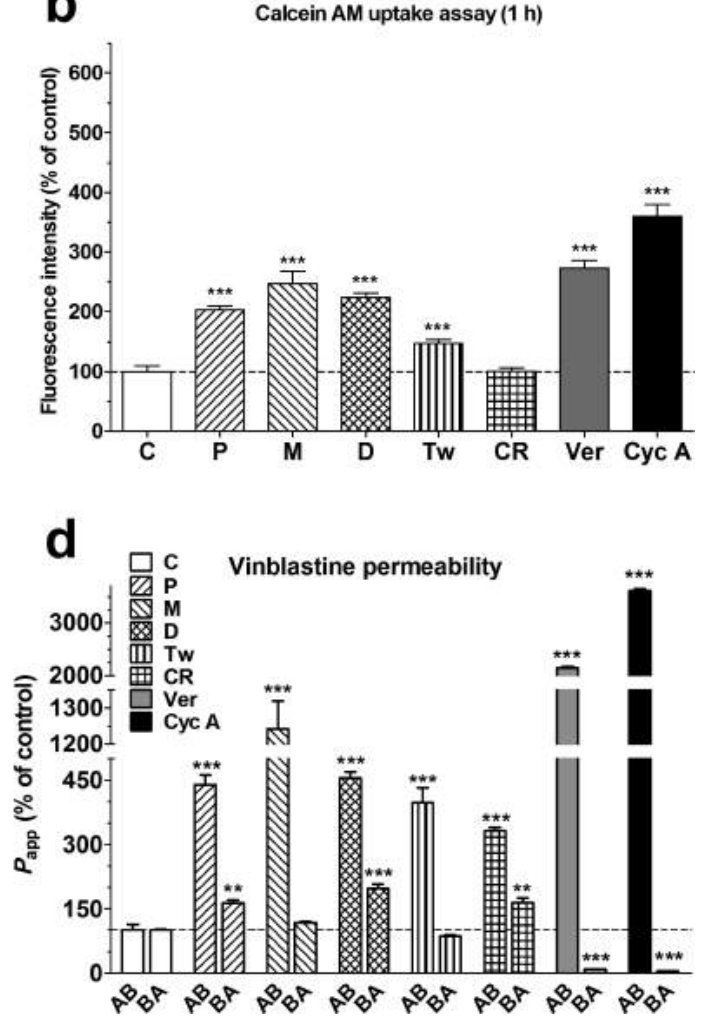

Figure 5. The effects of absorption enhancers on efflux pump activity measured by accumulation and permeability studies. The accumulation of efflux pump ligands (a) rhodamine 123 and (b) calcein AM was determined in cotreatment with sucrose esters, reference absorption enhancers, verapamil, and cyclosporin A on confluent Caco-2 cells. The effects of sucrose esters and reference absorption enhancers on the apparent permeability coefficients of (c) rhodamine 123 and (d) vinblastine in two directions were measured on confluent Caco-2 cell layers. Data are presented as mean $\pm \mathrm{SD}, n=3-6$; statistical analysis: ANOVA followed by Dunnett test (a and b) or two-way ANOVA followed by Bonferroni test (c and d); ${ }^{*} p<0.05,{ }^{* *} p<0.01,{ }^{* * *} p<0.001$; all groups were compared with control. Applied concentrations: P-1695, 30 $\mu \mathrm{g} / \mathrm{mL}$; M-1695, $60 \mu \mathrm{g} / \mathrm{mL}$; D-1216, $100 \mu \mathrm{g} / \mathrm{mL}$; Tween 80, $1000 \mu \mathrm{g} / \mathrm{mL}$; Cremophor RH40, $1000 \mu \mathrm{g} / \mathrm{mL}$; verapamil, $100 \mu \mathrm{M}$; and cyclosporine A, $10 \mu \mathrm{M}$. Abbreviations: $\mathrm{P}_{\text {app }}$, apparent permeability coefficient; R123, rhodamine 123; C, control; P, P-1695; M, M-1695; D, D-1216; Tw, Tween 80; CR, Cremophor RH40; Ver, verapamil; and Cyc A, cyclosporine A.

line (Fig. 6). Cells with enhanced membrane permeability were gated out by TO-PRO3 staining; therefore, in this assay, only Pgp inhibition was detected. The calcein accumulation observed in the absence of P-gp in MES-SA cells was not influenced by treatments. Because of the high-level expression of P-gp, MES$\mathrm{SA} / \mathrm{Dx} 5$ cells showed reduced calcein accumulation. The P-gpinhibitor verapamil $(100 \mu \mathrm{M})$ increased the fluorescent dye uptake to the level of the control cell line. Except for Tween 80, the surfactants did not influence the accumulation of calcein, indicating a lack of interaction with P-gp.

\section{DISCUSSION}

The present study describes the effect of three sucrose esters with same hydrophilic-lipophilic balance (HLB) value of 16 but different fatty acid chain length (C12-C16) (Supplementary Table S1) on cellular toxicity, drug permeability, intercellular junction morphology, efflux pump activity, and plasma membrane fluidity, giving a more complex and detailed view on their action on cultured intestinal epithelial cells than previous works.

\section{Sucrose Esters and Viability of Cultured Epithelial Cells}

On Caco-2 cells, D-1216 laurate ester (C12) was the least toxic, whereas M-1695 myristate (C14) and P-1695 palmitate (C16) ester had higher toxicity at both 1 - or 24 -h treatments (Fig. 1; Table 1). The same results were obtained by these sucrose esters in our previous works on Caco-2 intestinal ${ }^{44}$ and on RPMI 2650 human nasal epithelial cell lines. ${ }^{34}$ The same range of nontoxic concentrations were described for an unspecified sucrose monoester in Caco-2 cells, ${ }^{45}$ and for sucrose laurate, Tween 80, and Cremophor RH40 on MDCK dog kidney cells and two MDCK-derived cell lines. ${ }^{24}$ In our previous study on Cremophor RH40 and EL, similar toxicity results were obtained on intestinal epithelial and brain endothelial cells. ${ }^{6}$ Increased MTT dye conversion by Cremophor RH40 (Fig. 1a) was also observed previously. ${ }^{6}$ MTT assay involves several cellular processes ${ }^{46}$ which may be influenced by Cremophors. The toxic concentration of the reference surfactants was at least one order of magnitude higher in our studies and in the literature indicating that Tween 80 and Cremophor RH40 have a safer toxicity profile on cultured cells than sucrose esters.

In contrast to cell culture works, sucrose esters did not damage palatal and buccal pork tissues. ${ }^{20}$ Animal studies indicate that sucrose fatty acid esters are hydrolyzed by intestinal enzymes into sucrose and fatty acids and that their metabolites are not toxic. ${ }^{47-49}$ In addition, sucrose esters are chemically hydrolyzed under acidic or basic conditions ${ }^{50,51}$ and can be disintegrated by bacterial lipases. ${ }^{52}$ Tween 80 and Cremophor 

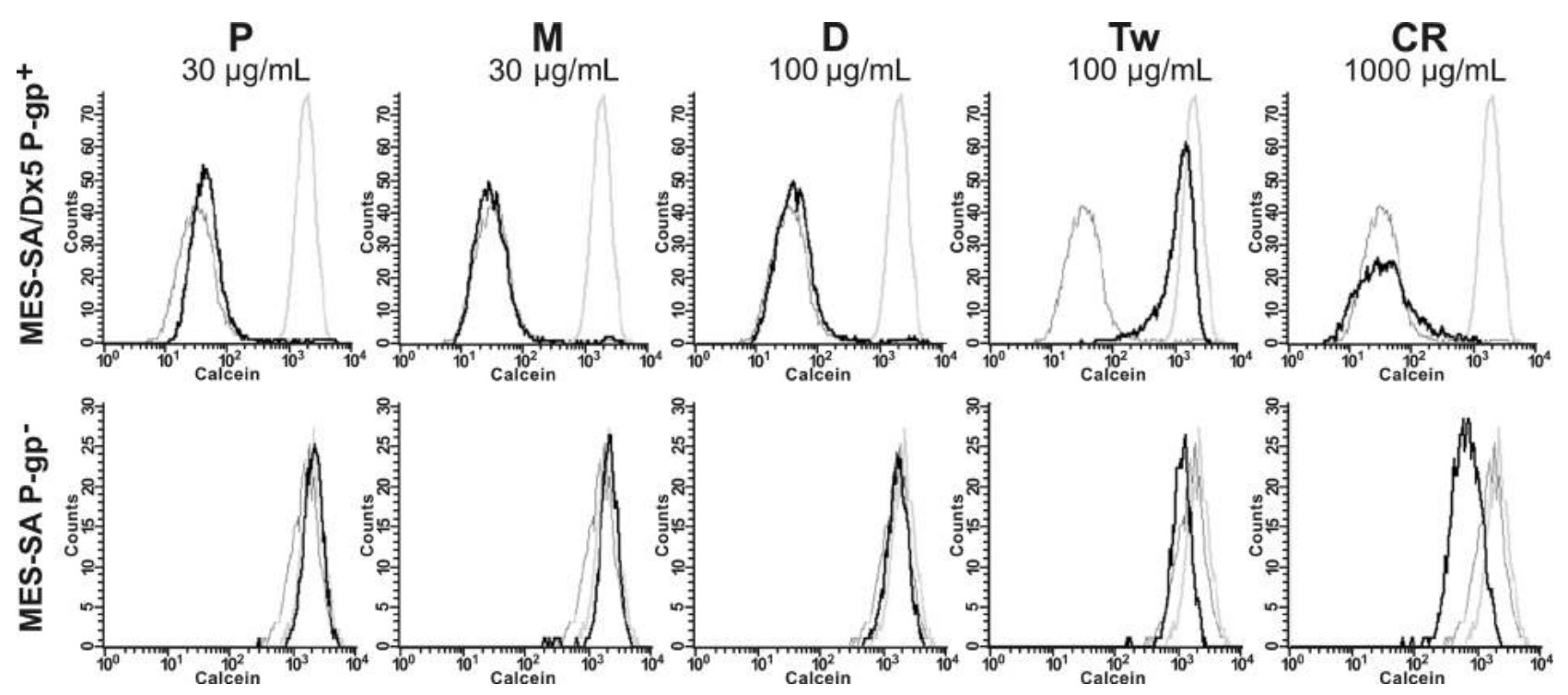

Figure 6. Effect of surfactants on calcein AM accumulation in P-gp positive MES-SA/Dx5 and P-gp negative MES-SA cell lines. Cellular calcein AM fluorescence was determined after the treatments with vehicle (dark gray), verapamil (light gray), and surfactants (black) and is shown in histogram. Applied concentrations: P-1695, $30 \mu \mathrm{g} / \mathrm{mL}$; M-1695, $30 \mu \mathrm{g} / \mathrm{mL}$; D-1216, $100 \mu \mathrm{g} / \mathrm{mL}$; Tween 80, $100 \mu \mathrm{g} / \mathrm{mL}$; Cremophor RH40, 1000 $\mu \mathrm{g} / \mathrm{mL}$; verapamil, $100 \mu \mathrm{M}$. Abbreviations: C, control; P, P-1695; M, M-1695; D, D-1216; Tw, Tween 80; CR, Cremophor RH40; Ver, verapamil. The assay was repeated three times; the histograms show data from a representative experiment.

RH40 are also degraded in the intestine or in the blood, ${ }^{53,54}$ but the effects of the metabolites are unknown. A recent review drew the attention to the dangers of using surfactants as food additives: the permeability enhancing and efflux pump inhibitor properties of these emulsifiers may cause intestinal barrier dysfunction and increase the incidence of allergic and autoimmune diseases, ${ }^{55}$ but conclusive animal studies and human data are missing. Despite the results of cell culture tests and the hypothesized dangers of surfactants ingested as additives in large quantities from foodstuff, the animal studies suggest that the toxicity of sucrose esters might be lower, if any, when given orally in small quantities as excipients. However, further chronic toxicity experiments are needed to prove the safety of sucrose esters as potential oral excipients.

\section{Sucrose Esters and the Permeability of Intestinal Epithelial Cells}

The tested surfactants possess high HLB as recommended for absorption enhancers in pharmaceutical applications. ${ }^{11,20} \mathrm{Sev}$ eral methods were used to determine the effect of sucrose esters on the paracellular and transcellular permeability.

Sucrose esters decreased the resistance and impedance of epithelial cell layers reflecting elevated ion penetration through the paracellular and transcellular pathways (Figs. 2a and 2b). Resistance of Caco-2 cell layers also dropped after treatment with sucrose esters in another study ${ }^{45}$ Reference surfactants did not change TEER of Caco-2 monolayers in the present experiments, our previous works, ${ }^{6}$ and in two independent studies ${ }^{56,57}$ indicating no effect on ion permeability through TJs. The resistance and impedance measurements suggest that sucrose esters enhance ion permeability through paracellular and transcellular pathways (Fig. 7).

We described for the first time that sucrose esters elevated the flux of the hydrophilic drug atenolol through Caco-2 cell layers, indicating the absorption-enhancer properties of these surfactants (Table 2). The tested excipients significantly increased the penetration of fluorescein in a concentration-dependent

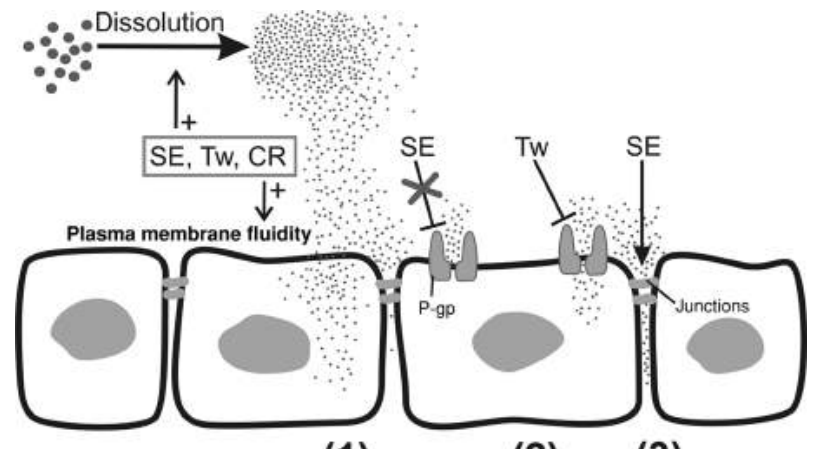

(1)

(2)

(3)

Figure 7. Sucrose esters and reference absorption enhancers may increase the penetration of molecules in several ways. (a) Surfactants enhance the dissolution of molecules and change plasma membrane fluidity that contributes to enhanced delivery of agents. (b) Tween 80 , but not sucrose esters, inhibits P-gp. (c) Sucrose esters may alter the function but not the visible morphology of cellular junctions, whereas reference molecules have no effect. Abbreviations: CR, Cremophor RH40; P-gp, P-glycoprotein; SE, sucrose esters; and Tw, Tween 80.

manner in the $\mathrm{AB}$ direction (Fig. 2c and Supplementary Figs. S1a, S1b, and S2). Because treatments were applied apically, similarly to per os drug administration, no permeability enhancement was observed in the opposite direction, except for M-1695 myristate ester. The increased permeability in BA direction induced by M-1695 may be linked to the highest drop of resistance caused by this sucrose ester as compared with others (Fig. 2b). The absorption-enhancing effects of sucrose esters ${ }^{11}$ especially laurate (D-1216), was demonstrated in several in vivo investigations. ${ }^{19-22}$ Tween 80 and Cremophor RH40 increased fluorescein permeability only in higher concentrations; therefore, sucrose esters are more effective in small concentrations (Supplementary Figs. S2a-S2c). Reference surfactants enhanced the permeability of all compounds, except the 
lipophilic model drugs caffeine and antipyrine. These class I compounds of the Biopharmaceutics Classification System are highly soluble and have high permeability, ${ }^{58}$ and the tested surfactants could not elevate further the already high permeability. Both Tween 80 and Cremophor RH40 are excipients in medicines (Tw: Fluxarix, Boostrix, Tubersol, Tripedia; CR: Neoral), and their penetration-increasing effects in the present study are in agreement with literature data. $3,34,57,59,60$

Immunostaining of junctional proteins, fluorescent labeling of F-actin, and transmission electron microscopy were used to visualize intercellular connections and demonstrate the integrity of the paracellular barrier (Fig. 3). It was observed for the first time that sucrose esters, Tween 80 and Cremophor $\mathrm{RH} 40$, did not cause any major change in the distribution of immunostaining for junctional proteins claudin-1, ZO-1, and $\beta$-catenin on Caco- 2 cells at the applied concentrations. Our previous work showed a similar effect for Cremophor $\mathrm{RH} 40$ on Caco- 2 cells. ${ }^{6}$ Surfactants slightly changed the organization of F-actin at the junctional region and basal part of the cells, but did not cause visible opening of the junctions. This F-actin redistribution can be linked to changes in the functional permeability of the junctions. ${ }^{4}$ Cytoskeletal F-actin changes caused by an undefined sucrose ester were also observed in Caco- 2 cells. ${ }^{45}$ Surfactants did not change the morphology of TJs investigated by electron microscopy. No disruption of junctions or cell layers were observed by these morphological examinations, confirming the safety of the selected surfactant concentrations and that sucrose esters do not cause visible damage of intercellular junctions. Caco- 2 cells allowed detailed imaging of interepithelial junctions. Intestinal tissue is a more complex system to study TJs but revealing pericellular junctional ring in high magnification is technically difficult. The use of intestinal epithelial cell line only is a limitation of the present study.

Sucrose esters fluidized the plasma membrane of living Caco-2 cells at lower concentrations than reference absorption enhancers, and caused stronger TMA-DPH fluorescence anisotropy reduction than Tween 80 or Cremophor RH40 (Fig. 4). Sucrose esters containing longer fatty acid chain increased better the membrane fluidity at lower concentrations, indicating a correlation between the length of fatty acid chain and effect on membrane fluidity. The maximal fluidization concentrations did not coincide with the maximal permeability enhancer effect of the surfactants. Several factors influence the membrane permeability of cells, including the fluidity of lipid bilayers, plasma membrane thickness and elasticity, and pore formation in the lipid layer. ${ }^{61,62}$ This study focused on membrane fluidization, but other changes in cell membrane properties could contribute to the observed penetration-enhancer effects. Other studies confirmed that surfactants, including our reference excipients, increase the fluidity of cellular plasma membranes, which is linked to enhanced membrane permeability and changes in the activity of membrane transporters and efflux pumps. ${ }^{63-65}$

The resistance, impedance, permeability, morphology, and membrane fluidity measurements indicate that several mechanisms are involved in the absorption enhancer effect of sucrose esters (Fig. 7). All the tested surfactants elevated plasma membrane fluidity, which can contribute to increased transcellular passage of molecules. Sucrose esters decreased both resistance and impedance indicating an effect on the function of intercellular junctions and cellular membranes, thus enhancing drug permeability through both the transcellular and paracellular routes. Tween 80 and Cremophor RH40 changed neither the morphology of intercellular junctions, nor the resistance of cell layers, suggesting no effect on paracellular transport.

\section{Effects of Sucrose Esters on Efflux Pumps}

Efflux transporters hinder drug delivery across biological barriers and blocking these pumps is considered as a way to increase drug penetration. ${ }^{66}$ Surfactants were described to inhibit uptake transporters, ${ }^{67}$ as well as efflux pumps. ${ }^{68,69}$ The effect of sucrose esters on efflux pumps is contradictory with studies describing inhibitory ${ }^{23,24}$ or no effect. ${ }^{18}$ In the present experiments, sucrose esters, unlike inhibitors or reference surfactants, increased the permeability of vinblastine and rhodamine 123 in $\mathrm{AB}$, but not in the other direction, suggesting no inhibitory effect on efflux pumps (Figs. 5c and 5d). Sucrose esters elevated rhodamine 123 and calcein AM accumulation in cotreatment, which may have suggested an inhibitory effect of efflux transporters. However, our experiments conducted on a model cell line expressing P-gp ruled out this possibility, as the sucrose esters did not influence the P-gp-mediated efflux in MES-SA/Dx5 cells (Fig. 6). Takaishi et al. ${ }^{18}$ suggested that elevated daunomycine flux in Caco-2 cells caused by sucrose esters is because of the permeabilization of the cellular membrane, but the present study is the first to experimentally prove that enhanced permeability is unrelated to P-gp.

Reference surfactants significantly increased the accumulation of rhodamine 123 in both pretreatment and cotreatment conditions. The uptake of calcein AM in Caco-2 cells was increased by Tween 80 and efflux pump inhibitors, but not by Cremophor RH40. The difference in the rhodamine and calcein AM uptake assays may be explained by the different specificity of the dyes: rhodamine 123 is a ligand of P-gp and BCRP, whereas calcein AM is a ligand of P-gp and MRP-1 and MRP$2 .^{24,43}$ Reference surfactants significantly increased the penetration of rhodamine 123 and vinblastine in $\mathrm{AB}$ direction, but reduced the permeability in the other direction only for rhodamine. Vinblastine is a ligand of both P-gp and MRP-2 that may explain the difference. Calcein AM uptake in P-gpexpressing MES-SA/Dx5 cells verified that Tween 80 is a P-gp inhibitor (Fig. 6). Our data indicate an inhibitory effect of the reference surfactants on efflux pump activity (Fig. 7) in agreement with other studies on Tween $80^{3,23,24,65,67}$ and Cremophor RH40. ${ }^{24,70}$

\section{CONCLUSIONS}

Sucrose esters are increasingly used as inactive ingredients in pharmaceutical products. Our study on cultured epithelial cells confirmed that sucrose esters are effective absorption enhancers for both hydrophilic drugs and efflux pump ligands. Sucrose esters enhance drug penetration by the transcellular and paracellular routes, but do not inhibit P-gp. It was demonstrated for the first time that sucrose esters fluidize the plasma membrane of epithelial cells in low concentrations. Reference surfactants Tween 80 and Cremophor $\mathrm{RH} 40$ increase drug penetration by the transcellular pathway and inhibition of efflux pump activity and not by acting on intercellular junctions. Sucrose esters as oral excipients may act differently than the reference absorption enhancers; therefore, further studies are needed to optimize oral dosage forms with these surfactants. 


\section{ACKNOWLEDGMENTS}

This work was supported by the European Union and the State of Hungary, co-financed by the European Social Fund (project numbers: TÁMOP 4.2.4. A/2-11-1-2012-0001, TÁMOP4.2.2.A-11/1/KONV-2012-0052), and the Dr. Rollin D. Hotchkiss Foundation.

\section{REFERENCES}

1. Strickley RG. 2004. Solubilizing excipients in oral and injectable formulations. Pharm Res 21:201-230.

2. Zhao X, Liu JP, Zhang X, Li Y. 2006. Enhancement of transdermal delivery of theophylline using microemulsion vehicle. Int J Pharm 327:58-64.

3. Rege BD, Yu LX, Hussain AS, Polli JE. 2001. Effect of common excipients on Caco-2 transport of low-permeability drugs. J Pharm Sci 90:1776-1786.

4. Deli MA. 2009. Potential use of tight junction modulators to reversibly open membranous barriers and improve drug delivery. Biochim Biophys Acta 1788:892-910.

5. Gelderblom H, Verweij J, Nooter K, Sparreboom A. 2001. Cremophor EL: The drawbacks and advantages of vehicle selection for drug formulation. Eur J Cancer 37:1590-1598.

6. Kiss L, Walter FR, Bocsik A, Veszelka S, Ózsvári B, Puskás LG, Szabó-Révész P, Deli MA. 2013. Kinetic analysis of the toxicity of pharmaceutical excipients Cremophor EL and RH40 on endothelial and epithelial cells. J Pharm Sci 102:1173-1181.

7. Daudé D, Remaud-Siméon M, André I. 2012. Sucrose analogs: An attractive (bio)source for glycodiversification. Nat Prod Rep 29:945960.

8. Chung O, Pomeranz Y, Goforth DR, Shogren MD, Finney KF. 1976. Improved sucrose esters in breadmaking. Cereal Chem 53:615625.

9. Garti N, Aserin A, Fanun M. 2000. Non-ionic sucrose esters microemulsions for food applications. Part 1. Water solubilization. Colloids Surf A Physicochem Eng Asp 164:27-38.

10. Muratsubaki Y. 2006. Cosmetics and materials. Application expansion in bidirection with other fields. Applied technology from cosmetics: Applied technology of sucrose fatty acid ester to cosmetics. Eng Mater 54:48-51.

11. Szúts A, Szabó-Révész P. 2012. Sucrose esters as natural surfactants in drug delivery systems-A mini-review. Int J Pharm 433: $1-9$.

12. Yamato K, Takahashi Y, Akiyama H, Tsuji K, Onishi H, Machida Y. 2009. Effect of penetration enhancers on transdermal delivery of propofol. Biol Pharm Bull 32:677-683.

13. Thevenin M, Grossiord JL, Poelman M. 1996. Sucrose esters/cosurfactant microemulsion systems for transdermal delivery: Assessment of bicontinuous structures. Int J Pharm 137:177-186.

14. Lehmann L, Keipert S, Gloor M. 2001. Effects of microemulsions on the stratum corneum and hydrocortisone penetration. Eur J Pharm Biopharm 52:129-136.

15. Garti N, Clement V, Leser M, Aserin A, Fanun M. 1999. Sucrose ester microemulsions. J Mol Liq 80:253-296.

16. Mollee HM, Steenvoorden DP, De Vringer T, Crommelin DJ. 2001. The influence of the incorporation of cholesterol and water on the particle size, bilayer thickness, melting behavior, and relative sucrose ester composition of reversed vesicles. J Pharm Sci 90:588-598.

17. Chansanroj K, Betz G. 2010. Sucrose esters with various hydrophilic-lipophilic properties: Novel controlled release agents for oral drug delivery matrix tablets prepared by direct compaction. Acta Biomater 6:3101-3109.

18. Takaishi N, Satsu H, Shimizu M. 2006. Enhanced daunomycin accumulation in human intestinal Caco-2 cells from non-ionic food emulsifiers unrelated to the P-glycoprotein inhibitory mechanism. Biosci Biotechnol Biochem 70:2703-2711.
19. Nakada Y, Awata N, Nakamichi C, Sugimoto I. 1988. The effect of additives on the oral mucosal absorption of human calcitonin in rats. $\mathrm{J}$ Pharmacobiodyn 11:395-401.

20. Ganem-Quintanar A, Quintanar-Guerrero D, Falson-Rieg F, Buri P. 1998. Ex vivo oral mucosal permeation of lidocaine hydrochloride with sucrose fatty acid esters as absorption enhancers. Int J Pharm 173:203-210.

21. Lerk P, Sucker H. 1993. Application of sucrose laurate, a new pharmaceutical excipient, in peroral formulations of cyclosporin A. Int $\mathrm{J}$ Pharm 92:197-202.

22. Onishi H, Imura Y, Uchida M, Machida Y. 2012. Enhancement potential of sucrose laurate (L-1695) on intestinal absorption of watersoluble high molecular weight compounds. Curr Drug Deliv 9:487494.

23. Cornaire G, Woodley J, Hermann P, Cloarec A, Arellano C, Houin G. 2004. Impact of excipients on the absorption of P-glycoprotein substrates in vitro and in vivo. Int $\mathrm{J}$ Pharm 278:119-131.

24. Hanke U, May K, Rozehnal V, Nagel S, Siegmund W, Weitschies W. 2010. Commonly used nonionic surfactants interact differently with the human efflux transporters ABCB1 (p-glycoprotein) and ABCC2 (MRP2). Eur J Pharm Biopharm 76:260-268.

25. Artursson P, Palm K, Luthman K. 2001. Caco-2 monolayers in experimental and theoretical predictions of drug transport. Adv Drug Deliv Rev 46:27-43.

26. Hellinger E, Bakk ML, Pócza P, Tihanyi K, Vastag M. 2010. Drug penetration model of vinblastine-treated Caco-2 cultures. Eur J Pharm Sci 41:96-106.

27. Hellinger E, Veszelka S, Tóth AE, Walter F, Kittel Á, Bakk ML, Tihanyi K, Háda V, Nakagawa S, Duy TDH, Niwa M, Deli MA, Vastag M. 2012. Comparison of brain capillary endothelial cell-based and epithelial (MDCK-MDR1, Caco-2, and VB-Caco-2) cell-based surrogate bloodbrain barrier penetration models. Eur J Pharm Biopharm 82:340351.

28. Englund G, Rorsman F, Rönnblom A, Karlbom U, Lazorova L, Gråsjö J, Kindmark A, Artursson P. 2006. Regional levels of drug transporters along the human intestinal tract: Co-expression of $\mathrm{ABC}$ and SLC transporters and comparison with Caco-2 cells. Eur J Pharm Sci 29:269-277.

29. Hayeshi R, Hilgendorf C, Artursson P, Augustijns P, Brodin B, Dehertogh P, Fisher K, Fossati L, Hovenkamp E, Korjamo T, Masungi C, Maubon N, Mols R, Müllertz A, Mönkkönen J, O'Driscoll C, OppersTiemissen HM, Ragnarsson EG, Rooseboom M, Ungell AL. 2008. Comparison of drug transporter gene expression and functionality in Caco-2 cells from 10 different laboratories. Eur J Pharm Sci 35:383-396.

30. Chen G, Jaffrézou JP, Fleming WH, Durán GE, Sikic BI. 1994. Prevalence of multidrug resistance related to activation of the mdr1 gene in human sarcoma mutants derived by single-step doxorubicin selection. Cancer Res 54:4980-4987.

31. Benson K, Cramer S, Galla HJ. 2013. Impedance-based cell monitoring: Barrier properties and beyond. Fluids Barriers CNS 10:5. 32. Atienza JM, Yu N, Kirstein SL, Xi B, Wang X, Xu X, Abassi YA. 2006. Dynamic and label-free cell-based assays using the real-time cell electronic sensing system. Assay Drug Dev Technol 4:597-607.

33. Ózsvári B, Puskás LG, Nagy LI, Kanizsai I, Gyuris M, Madácsi R, Fehér LZ, Gerô D, Szabó C. 2010. A cell-microelectronic sensing technique for the screening of cytoprotective compounds. Int J Mol Med 25:525-530.

34. Kürti L, Veszelka S, Bocsik A, Dung NTK, Ózsvári B, Puskás LG, Kittel Á, Szabó-Révész P, Deli MA. 2012. The effect of sucrose esters on a culture model of the nasal barrier. Toxicol In Vitro 26:445-454.

35. Török Z, Horváth I, Goloubinoff $\mathrm{P}$, Kovács E, Glatz A, Balogh G, Vígh L. 1997. Evidence for a lipochaperonin: Association of active protein-folding GroESL oligomers with lipids can stabilize membranes under heat shock conditions. Proc Natl Acad Sci USA 94:2192-2197.

36. Balogh G, Maulucci G, Gombos I, Horváth I, Török Z, Péter M, Fodor E, Páli T, Benkő S, Parasassi T, De Spirito M, Harwood JL, Vígh L. 2011. Heat stress causes spatially-distinct membrane re-modelling in K562 leukemia cells. PLoS One 6:e21182. 
37. Juvale K, Pape VF, Wiese M. 2012. Investigation of chalcones and benzochalcones as inhibitors of breast cancer resistance protein. Bioorg Med Chem 20:346-355.

38. Türk D, Hall M D, Chu B F, Ludwig J A, Fales H M, Gottesman M, Szakács G. 2009. Identification of compounds selectively killing multidrug-resistant cancer cells. Cancer Res 69:8293-8301.

39. Karászi E, Jakab K, Homolya L, Szakács G, Holló Z, Telek B, Kiss A, Rejtô L, Nahajevszky S, Sarkadi B, Kappelmayer J. 2001. Calcein assay for multidrug resistance reliably predicts therapy response and survival rate in acute myeloid leukaemia. Br J Haematol 112:308-314. 40. Weis M, Mortensen SA, Rassing MR, Møller-Sonnergaard J, Poulsen G, Rasmussen SN. 1994. Bioavailability of four oral coenzyme Q10 formulations in healthy volunteers. Mol Aspects Med 15(Suppl):s273-s280.

41. Mercke Odeberg J, Lignell A, Pettersson A, Höglund P. 2003. Oral bioavailability of the antioxidant astaxanthin in humans is enhanced by incorporation of lipid based formulations. Eur J Pharm Sci 19:299_ 304.

42. Legen I, Kristl A. 2004. D-glucose triggers multidrug resistanceassociated protein (MRP)-mediated secretion of fluorescein across rat jejunum in vitro. Pharm Res 21:635-640.

43. Schinkel AH, Jonker JW. 2003. Mammalian drug efflux transporters of the ATP binding cassette (ABC) family: An overview. Adv Drug Deliv Rev 55:3-29.

44. Szúts A, Láng $P$, Ambrus R, Kiss L, Deli MA, Szabó-Révész P. 2011. Applicability of sucrose laurate as surfactant in solid dispersions prepared by melt technology. Int J Pharm 410:107-110.

45. Mine Y, Zhang JW. 2003. Surfactants enhance the tight-junction permeability of food allergens in human intestinal epithelial Caco-2 cells. Int Arch Allergy Immunol 130:135-142.

46. Liu Y, Peterson DA, Kimura H, Schubert D. 1997. Mechanism of cellular 3-(4,5-dimethylthiazol-2-yl)-2,5-diphenyltetrazolium bromide (MTT) reduction. J Neurochem 69:581-593.

47. Berry J, Turner D. 1960. The enzymatic hydrolysis and tissue oxidation of fatty acid esters of sucrose. J Am Oil Chem Soc 37:302-305.

48. Shigeoka T, Izawa O, Kitazawa K, Yamauchi F, Murata T. 1984. Studies on the metabolic fate of sucrose esters in rats. Food Chem Toxicol 22:409-414.

49. Noker PE, Lin TH, Hill DL, Shigeoka T. 1997. Metabolism of 14C-labelled sucrose esters of stearic acid in rats. Food Chem Toxicol 35:589-595.

50. Christiansen A, Backensfeld T, Kühn S, Weitschies W. 2011. Investigating the stability of the nonionic surfactants tocopheryl polyethylene glycol succinate and sucrose laurate by HPLC-MS, DAD, and CAD. J Pharm Sci 100:1773-1782.

51. Okumura H, Kitazawa N, Wada S, Hotta H. 2011. Stability of sucrose fatty acid esters under acidic and basic conditions. J Oleo Sci 60:313-320.

52. Marciello M, Mateo C, Guisan JM. 2011. Full enzymatic hydrolysis of commercial sucrose laurate by immobilized-stabilized derivatives of lipase from Thermomyces lanuginosa. Colloids Surf B Biointerfaces 84:556-560.

53. Christiansen A, Backensfeld T, Weitschies W. 2010. Effects of nonionic surfactants on in vitro triglyceride digestion and their susceptibility to digestion by pancreatic enzymes. Eur J Pharm Sci 41:376-382. 54. van Tellingen O, Beijnen JH, Verweij J, Scherrenburg EJ, Nooijen WJ, Sparreboom A. 1999. Rapid esterase-sensitive breakdown of polysorbate 80 and its impact on the plasma pharmacokinetics of docetaxel and metabolites in mice. Clin Cancer Res 5:2918-2924.

55. Csáki KF. 2011. Synthetic surfactant food additives can cause intestinal barrier dysfunction. Med Hypotheses 76:676-681.

56. Yu H, Hu YQ, Ip FCF, Zuo Z, Han YF, Ip NY. 2011. Intestinal transport of bis(12)-hupyridone in Caco-2 cells and its improved permeability by the surfactant Brij-35. Biopharm Drug Dispos 32:140-150.

57. Takahashi Y, Kondo H, Yasuda T, Watanabe T, Kobayashi S, Yokohama S. 2002. Common solubilizers to estimate the Caco-2 transport of poorly water-soluble drugs. Int J Pharm 246:85-94.

58. Wu CY, Benet LZ. 2005. Predicting drug disposition via application of BCS: Transport/absorption/ elimination interplay and development of a biopharmaceutics drug disposition classification system. Pharm Res 22:11-23.

59. Nerurkar MM, Ho NF, Burton PS, Vidmar TJ, Borchardt RT. 1997. Mechanistic roles of neutral surfactants on concurrent polarized and passive membrane transport of a model peptide in Caco-2 cells. J Pharm Sci 86:813-821.

60. Horvát S, Fehér A, Wolburg H, Sipos P, Veszelka S, Tóth A, Kiss L, Kurunczi A, Balogh G, Kürti L, Erôs I, Szabó-Révész P, Deli MA. 2009. Sodium hyaluronate as a mucoadhesive component in nasal formulation enhances delivery of molecules to brain tissue. Eur J Pharm Biopharm 72:252-259.

61. Lichtenberger LM, Zhou Y, Dial EJ, Raphael RM. 2006. NSAID injury to the gastrointestinal tract: Evidence that NSAIDs interact with phospholipids to weaken the hydrophobic surface barrier and induce the formation of unstable pores in membranes. J Pharm Pharmacol 58:1421-1428.

62. Peetla C, Vijayaraghavalu S, Labhasetwar V. 2013. Biophysics of cell membrane lipids in cancer drug resistance: Implications for drug transport and drug delivery with nanoparticles. Adv Drug Deliv Rev 65:1686-1698.

63. Aungst BJ. 2000. Intestinal permeation enhancers. J Pharm Sci 89:429-442.

64. Rege BD, Kao JPY, Polli JE. 2002. Effects of nonionic surfactants on membrane transporters in Caco-2 cell monolayers. Eur J Pharm Sci 16:237-246

65. Nerurkar MM, Ho NF, Burton PS, Vidmar TJ, Borchardt RT. 1997. Mechanistic roles of neutral surfactants on concurrent polarized and passive membrane transport of a model peptide in Caco-2 cells. J Pharm Sci 86(7):813-821.

66. Darby RA, Callaghan R, McMahon RM. 2011. P-glycoprotein inhibition: The past, the present and the future. Curr Drug Metab 12:722731.

67. Engel A, Oswald S, Siegmund W, Keiser M. 2012. Pharmaceutical excipients influence the function of human uptake transporting proteins. Mol Pharm 9:2577-2581.

68. Hugger ED, Novak BL, Burton PS, Audus KL, Borchardt RT. 2002. A comparison of commonly used polyethoxylated pharmaceutical excipients on their ability to inhibit P-glycoprotein activity in vitro. J Pharm Sci 91:1991-2002.

69. Bogman K, Erne-Brand F, Alsenz J, Drewe J. 2003. The role of surfactants in the reversal of active transport mediated by multidrug resistance proteins. J Pharm Sci 92:1250-1261.

70. Yamagata T, Kusuhara H, Morishita M, Takayama K, Benameur H, Sugiyama Y. 2007. Effect of excipients on breast cancer resistance protein substrate uptake activity. J Control Release 124:1-5. 


\section{Supporting Information}

\section{Curve fitting for toxicity data}

For the toxicity assays the non-toxic concentrations (TC0), 50\% toxic concentrations (TC50) and concentrations causing death in all cell (TC100) were calculated from fitted curves (GraphPad Prism 5.0, GraphPad Software Inc., San Diego, CA, USA) using the following equation:

$$
\begin{aligned}
& \mathrm{Y}=\text { Bottom }+\frac{\text { Top }- \text { Bottom }}{1+10^{(\operatorname{logEC} 50-\mathrm{X}) \times \text { Hillslope }}} \\
& \operatorname{logEC} 50=\operatorname{logECF}-\frac{1}{\text { Hillslope }} \times \log \left(\frac{F}{100-F}\right)
\end{aligned}
$$

At the first step the $\operatorname{logTC} 50$ was calculated by Eq. (1), then TC0 and TC100 were further analyzed by Eq. (2). The ECF is the concentration of surfactants that gives a response F percent $(0 \%$ or $100 \%)$ of the way between Bottom and Top. HillSlope describes the steepness of the family of curves. Top and Bottom are plateaus in the units of the $\mathrm{Y}$ axis.

\section{Calculation of clearance and apparent permeability coefficients}

For the permeability measurments the apparent permeability coefficient $\left(\mathrm{P}_{\text {app }}\right)$ in apical to basal (AB) direction was calculated by this equation:

$$
\mathrm{P}_{\text {app }}(\mathrm{cm} / \mathrm{s})=\frac{[C]_{B} \times V_{B}}{A \times[C]_{A} \times t}
$$

where $[\mathrm{C}]_{\mathrm{B}}$ is the concentration of the tracer in the basal compartment after 1 hour; $[\mathrm{C}]_{\mathrm{A}}$ is the concentration in the apical compartment at 0 hour; $\mathrm{V}_{\mathrm{B}}$ is the volume of the basal compartment $(1.5 \mathrm{ml})$; $\mathrm{A}$ is the surface area available for transport $\left(1.12 \mathrm{~cm}^{2}\right) ; t$ is the length of the time of the transport assay (1 hour). To calculate the apparent permeability of the opposite transport direction (BA) the following equation was used:

$$
\mathrm{P}_{\text {app }}(\mathrm{cm} / \mathrm{s})=\frac{[C]_{A} \times V_{A}}{A \times[C]_{B} \times t}
$$

where $[C]_{A}$ was the concentration of the tracer in apical compartment after 1 hour; $[C]_{B}$ is the concentration in basal compartment at 0 hour, and $\mathrm{V}_{\mathrm{A}}$ is the volume of the apical compartment $(0.5 \mathrm{ml})$. Clearance of vinblastine and fluorescein was also determined at different time points in both penetration directions, using the following equations:

$$
\begin{aligned}
& \mathrm{Cl}_{\mathrm{t} 60}(\mu \mathrm{l})=\frac{\left[C_{t 0-60}\right]_{\text {Accep }} \times V_{\text {Accep }}}{[C]_{\text {Donor }}} \\
& \mathrm{Cl}_{\mathrm{t} 120}(\mu \mathrm{l})=\frac{\left[C_{t 60-120}\right]_{\text {Accep }} \times V_{\text {Accep }}}{[C]_{\text {Donor }}-\left[C_{t 0-60}\right]_{\text {Accep }}}
\end{aligned}
$$


where $\mathrm{Cl}_{600}$ and $\mathrm{Cl}_{\mathrm{t} 120}$ was the clearance at 60 and 120 minutes, $\left[\mathrm{C}_{\mathrm{t0}-60}\right]_{\text {Accep }}$ and $\left[\mathrm{C}_{\mathrm{t} 60-120}\right]_{\text {Accep }}$ was the concentration of the tracer in acceptor compartment after 60 and 120 minutes, $\mathrm{V}_{\text {accep }}$ was the volume of acceptor phase, $[\mathrm{C}]_{\text {Donor }}$ was the concentration at the beginning of the experiment. The average cleared volumes were plotted vs. time, and lines were fitted using the least squares method. The slope $(\mu 1 / \mathrm{min})$ of the fitted line was used to calculate the apparent permeability by the following equation:

$$
\mathrm{P}_{\text {app }}(\mathrm{cm} / \mathrm{s})=\frac{\text { Slope }}{A \times t}
$$

where $\mathrm{A}$ is the surface area available for transport $\left(112 \mathrm{~mm}^{2}\right) ; t$ is 60 seconds. 


\section{Supporting table}

\begin{tabular}{|c|c|c|c|}
\hline & P-1695 & M-1695 & D-1216 \\
\hline $\begin{array}{l}\text { Chemical } \\
\text { structure }\end{array}$ & R-COOCl & $\mathrm{O}_{\mathrm{O}-\mathrm{R}}^{\mathrm{O}}$ & $\mathrm{CH}_{2} \mathrm{O}-\mathrm{R}$ \\
\hline $\begin{array}{c}\text { R-carbon } \\
\text { chain lenght }\end{array}$ & 16 & 14 & 12 \\
\hline HLB & 16 & 16 & 16 \\
\hline CMC & $28-250 \mu \mathrm{M}^{71}$ & $28-250 \mu \mathrm{M}^{71}$ & $500 \mu \mathrm{g} / \mathrm{ml}^{72}$ \\
\hline Trade name & $\begin{array}{c}\text { Ryoto sugar ester P- } \\
1695\end{array}$ & $\begin{array}{c}\text { Ryoto sugar ester M- } \\
1695\end{array}$ & $\begin{array}{c}\text { Surfhope SE Pharma D- } \\
1216 \text { (US DMF) }\end{array}$ \\
\hline $\begin{array}{l}\text { Chemical } \\
\text { name }\end{array}$ & palmitate sucrose ester & myristate sucrose ester & laurate sucrose ester \\
\hline Solubility & water soluble & water soluble & water soluble \\
\hline
\end{tabular}

\begin{tabular}{|c|c|c|}
\hline & Polysorbate 80 (Ph.Eur.) & $\begin{array}{c}\text { Macrogol-glycerolhydroxystearate } \\
40 \text { (Ph.Eur.) }\end{array}$ \\
\hline $\begin{array}{l}\text { Chemical } \\
\text { structure }\end{array}$ & $\left.\mathrm{HO}\left(\mathrm{CH}_{2} \mathrm{CH}_{2} \mathrm{O}\right)_{m}\right)-\left(\mathrm{OCH}_{2} \mathrm{CH}_{2}\right) \times \mathrm{OH}$ & m \\
\hline $\begin{array}{c}\text { R-carbon } \\
\text { chain lenght }\end{array}$ & 18 & 18 \\
\hline HLB & 15 & 15 \\
\hline CMC & $50-63 \mu \mathrm{g} / \mathrm{ml}^{53,59}$ & $390 \mu \mathrm{g} / \mathrm{ml}^{50}$ \\
\hline Trade name & Tween 80 & Cremophor RH40 \\
\hline $\begin{array}{l}\text { Chemical } \\
\text { name }\end{array}$ & $\begin{array}{c}\text { polyethoxylatedsorbitan and oleic } \\
\text { acid }\end{array}$ & $\begin{array}{l}\text { polyethoxylated } 40 \text { hydrogenated } \\
\text { castor oil }\end{array}$ \\
\hline Solubility & water soluble & water soluble \\
\hline
\end{tabular}

Table S1. Properties of surfactants

R- carbon chain length, carbon chain length of fatty acid residues; CMC: critical micelle concentration; HLB: hydrophilic-lipophilic balance; US DMF, US drug master file.; Ph.Eur., European Pharmacopoea. 


\section{Supporting figures}
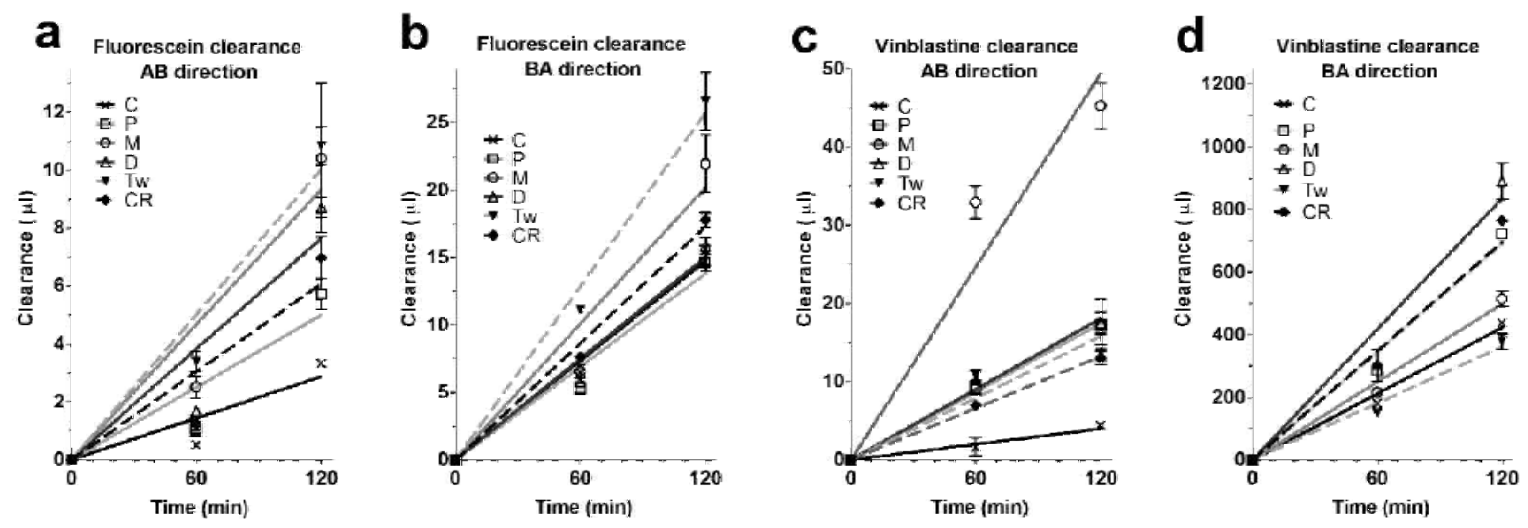

Figure S1. Effect of sucrose esters and reference surfactants on fluorescein and vinblastine clearance

The effect of sucrose esters and reference absorption enhancers on clearance of fluorescein and vinblastine on confluent Caco-2 cell layers was measured at 60 and 120 minutes. The applied concentrations of surfactants: P1695, $30 \mu \mathrm{g} / \mathrm{ml}$; M-1695, $60 \mu \mathrm{g} / \mathrm{ml}$; D-1216, $100 \mu \mathrm{g} / \mathrm{ml}$; Tween 80, $1000 \mu \mathrm{g} / \mathrm{ml}$; Cremophor RH40, $1000 \mu \mathrm{g} / \mathrm{ml}$. Abbreviations: C, control; P, P-1695; M, M-1695; D, D-1216; Tw, Tween 80; CR, Cremophor RH40. 

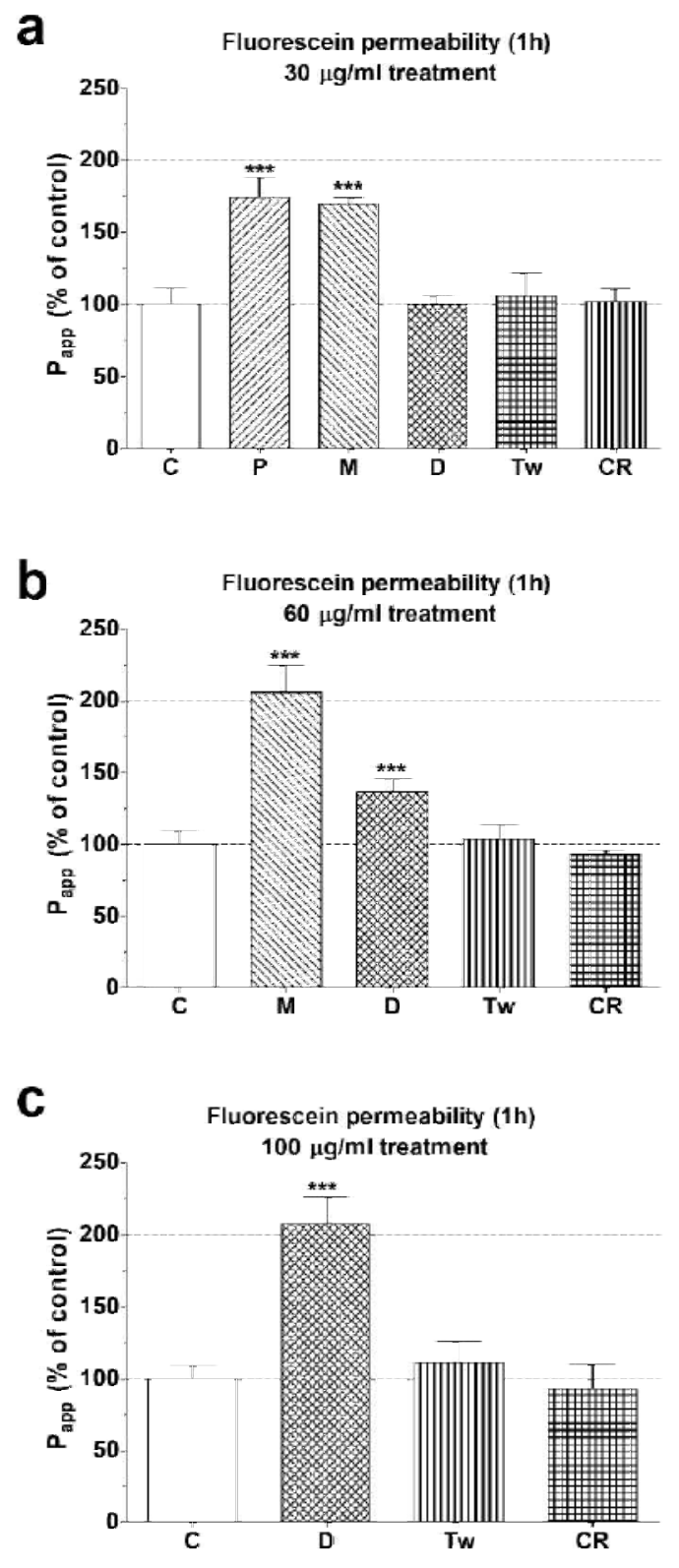

Figure S2. Effect of sucrose esters and reference surfactants on fluorescein permeability

The effect of sucrose esters and reference absorption enhancers on the apparent permeability coefficients of fluorescein on confluent Caco-2 cell layers applied in the same concentrations of (a) $30 \mu \mathrm{g} / \mathrm{ml}$, (b) $60 \mu \mathrm{g} / \mathrm{ml}$, (c) $100 \mu \mathrm{g} / \mathrm{ml}$. Data are presented as mean \pm S.D., $\mathrm{n}=3$; statistical analysis: ANOVA followed by Dunnett test; *** $P<0.001$, all groups were compared to control. Abbreviations: $\mathrm{P}_{\text {app }}$, apparent permeability coefficient; $\mathrm{C}$, control; P, P-1695; M, M-1695; D, D-1216; Tw, Tween 80; CR, Cremophor RH40. 

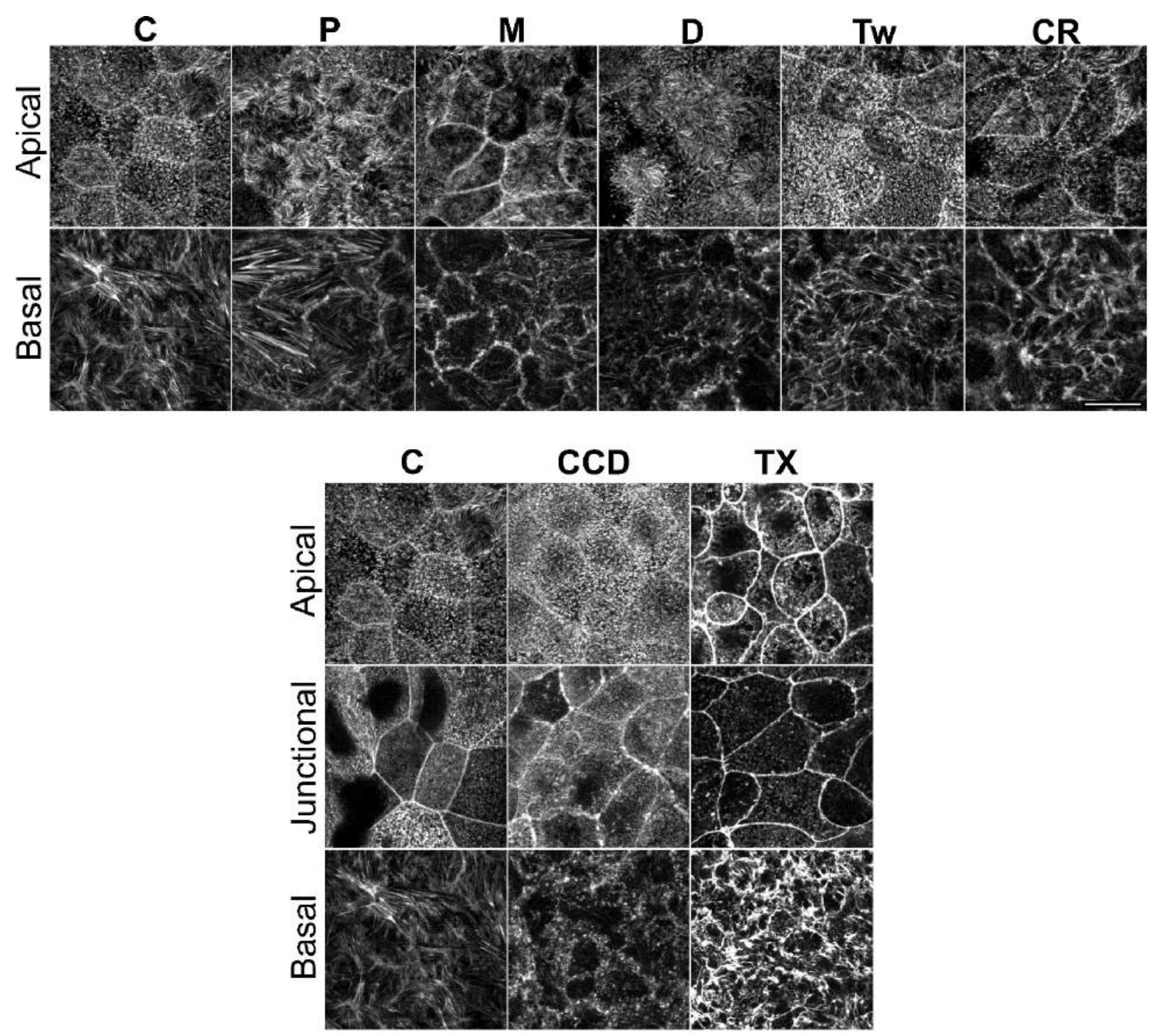

Figure S3. Effects of surfactants, cytochalasin D and Triton X-100 on actin cytoskeleton

Fluorescent staining for F-actin cytoskeletal protein with phalloidin labeled by Alexa Fluor 488 in human Caco2 intestinal epithelial cells after 1 hour treatment with sucrose esters, reference absorption enhancers, cytochalasin D or Triton X-100. Images were captured from two regions of cells after treatment with absorption enhancers: apical and basal part; and three different region of cells with treatment by cytochalasin D and Triton X-100: apical, junctional and basal part. Abbreviations: C, control; M, M-1695; P, P-1695; D, D-1216; Tw, Tween 80; CR, Cremophor RH40; CCD, cytochalasin D; TX, Triton X-100. Bar = $15 \mu \mathrm{m}$. 

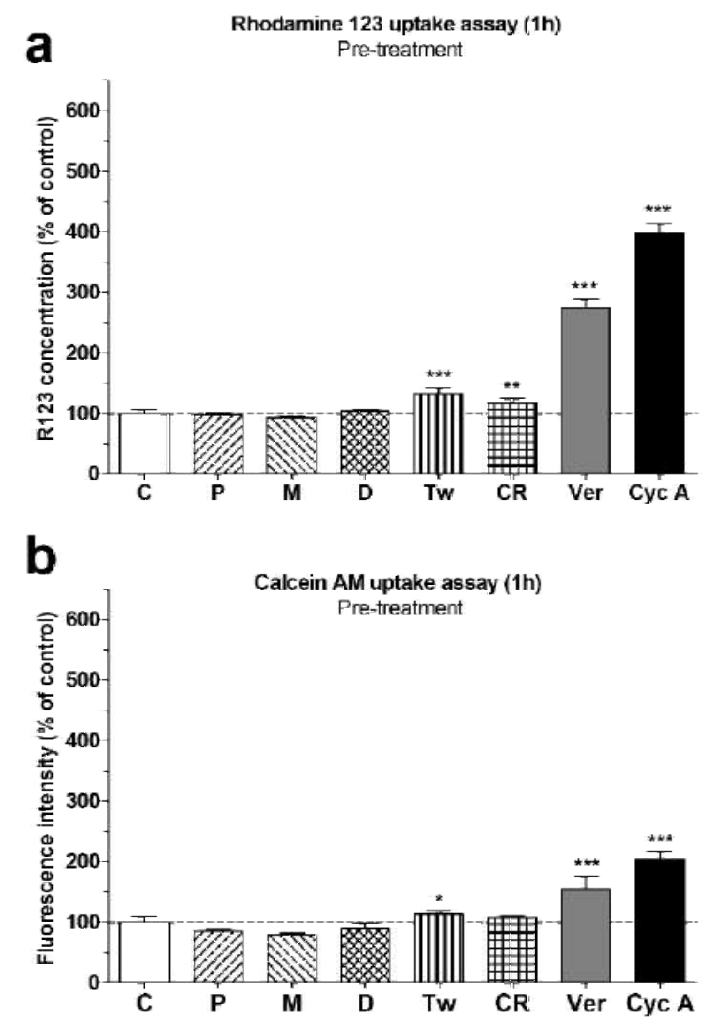

Figure S4. Effect of pre-treatment with surfactants on efflux pump activity

Effect of pre-treatment with sucrose esters, reference absorption enhancers, verapamil and cyclosporin A on the accumulation of efflux pump ligand (a) rhodamine 123 and (b) calcein AM in confluent Caco-2 cell layers. Data are presented as mean \pm S.D., $\mathrm{n}=6$; statistical analysis: ANOVA followed by Dunnett test; $* P<0.05$, ${ }^{* *} P<0.01,{ }^{* * *} P<0.001$, all groups were compared to control. Applied concentrations: M-1695, $60 \mu \mathrm{g} / \mathrm{ml} ; \mathrm{P}-$ 1695, $30 \mu \mathrm{g} / \mathrm{ml}$; D-1216, $100 \mu \mathrm{g} / \mathrm{ml}$; Tween 80, $1000 \mu \mathrm{g} / \mathrm{ml}$; Cremophor RH40, $1000 \mu \mathrm{g} / \mathrm{ml}$; verapamil, $100 \mu \mathrm{M}$; cyclosporine A, $10 \mu \mathrm{M}$. Abbreviations: R123, Rhodamine 123; C, control; M, M-1695; P, P-1695; D, D-1216; Tw, Tween 80; CR, Cremophor RH40; Ver, verapamil; Cyc A, cyclosporine A. 